Portland State University

PDXScholar

\title{
Understanding the Impacts of Urbanization on the Avian Community of Portland Oregon and Evaluation of the Portland Oregon Backyard Habitat Certification Program
}

Andrew Daniel Gibbs

Portland State University

Follow this and additional works at: https://pdxscholar.library.pdx.edu/open_access_etds

Part of the Biology Commons

Let us know how access to this document benefits you.

\section{Recommended Citation}

Gibbs, Andrew Daniel, "Understanding the Impacts of Urbanization on the Avian Community of Portland Oregon and Evaluation of the Portland Oregon Backyard Habitat Certification Program" (2018).

Dissertations and Theses. Paper 4386.

https://doi.org/10.15760/etd. 6270

This Dissertation is brought to you for free and open access. It has been accepted for inclusion in Dissertations and Theses by an authorized administrator of PDXScholar. Please contact us if we can make this document more accessible: pdxscholar@pdx.edu. 
Understanding the Impacts of Urbanization on the Avian Community of Portland Oregon and Evaluation of the Portland Oregon Backyard Habitat Certification Program

by

Andrew Daniel Gibbs

A dissertation submitted in partial fulfillment of the requirements for the degree of

Doctor of Philosophy

in

Biology

Dissertation Committee:

Michael T. Murphy, Chair

Marion Dresner

Luis A. Ruedas

Mitchell B. Cruzan

Catherine E. de Rivera

Portland State University

2018 
(C) 2018 Andrew Daniel Gibbs 


\begin{abstract}
Over fifty percent of humans live in cities. The environmental cost of this is massive, as is the potential for utilizing privately held yards as an integral part of conservation in urban areas. The Backyard Habitat Certification Program (BHCP) in Portland, Oregon, was established to reduce invasive plants, support wildlife, and promote conservation. The program involves $>3000$ yards certified at three tiers. While onsite inspections are required to verify compliance, there has never been an assessment of the value of these yards to wildlife. In chapter 1 I examined the relationships between the urban landscape and bird distributions outside of yards. In chapter 2 I evaluated the ability of the program to separate yards by assessing differences in vegetation structure and composition. In chapter 3 I tested if avian abundance, richness and diversity in yards are a product of responses to yard or landscape vegetation structure. I collected avian data at 146 yards and 73 random locations in 2013 and 2014. I used public landscape data and collected yard data in the field. Avian abundance, richness, and diversity were affected negatively by urbanization (especially impervious surface) and population density, but positively by tree cover. The BHCP was effective at distinguishing platinum yards from others, but overlap was relatively high among gold, silver and uncertified yards. Avian abundance, richness and diversity within yards was less affected by yard vegetation than the structure of habitat in the surrounding landscape. Species responded individualistically to yard vegetation and the urban landscape, and response was a continuum of tolerance to urbanization. Ultimately, the ability of yards to support wildlife will depend on widescale neighborhood participation.
\end{abstract}




\section{Dedication}

I dedicate this dissertation to my family, who never lost faith in me through this entire process.

To: Dan, Kathy, Sarah, Nick and Mary-Lou

I love you. Your support saved my life and made this project possible. 


\section{Acknowledgements}

Dogs:

(in order of appearance)

- Blue

- Joey

- Mandy

- Daisy

- Bandit

- Uma

- Rocky

- Crazy

- Abby

- Pepper

- Sage

- Ollie

- Lilly

- Penny

- Charlie

- Maya

- Sammy

- Lucy
People:

(In order of meeting me)

Kathy Gibbs

Daniel Gibbs

Sarah Gibbs

Mary Lou Sexton

Jay Haser

Eric Niskanen

John Kidney

Meghan Barnett

Nikkie West

The owners of 199 yards!!

Cecily Bronson

Abigail Bender 


\section{Table of Contents}

$\begin{array}{ll}\text { Abstract } & \text { Page } \\ \text { Dedication } & \text { i } \\ \text { Acknowledgments } & \text { ii } \\ \text { List of Tables } & \text { iii } \\ \text { List of Figures } & \mathrm{V} \\ & \mathrm{vi} \\ \text { Introduction } & \\ \text { Chapter } 1 & 1\end{array}$

Avian Community and Urban Habitat Analysis:

Total Avian Abundance Species Richness and Species Diversity Decline with Increasing Urbanization in Portland Oregon.

Chapter 2

56

The efficacy of Portland Audubon's Backyard Certification Program at creating natural habitat

Chapter 3

100

The Ability of the Backyard Habitat Certification Program, Certified Habitat Yards, to Support the Avian Community of Portland Oregon

Appendix A - Chapter 1 Tables and Figures

152

Appendix B - Chapter 2 Tables and Figures 155

Appendix C - Chapter 3 Tables and Figures 164 


\section{List of Tables}

Chapter 1

Table 1.1

Page

Table 1.2

34

Table 1.3

36

Table 1.4

37

Table 1.5

38

Table 1.6

39

Table 1.7

40

Table 1.8

41

Table 1.9

42

Table 1.10

43

45

Chapter 2

Table 2.1

81

Table 2.2

84

Table 2.3

85

Table 2.4

86

Table 2.5

87

Chapter 3

Table 3.1

132

Table 3.2

133

Table 3.3

134

Table 3.4

135

Table 3.5

136

Table 3.6

137

Table 3.7

138

Table 3.8

139

Table 3.9

142 


\section{List of Figures}

Chapter 1

Page

Figure 1.1

33

Chapter 2

Figure 2.1 80

Figure $2.2 \quad 82$

Figure $2.3 \quad 82$

Figure $2.4 \quad 83$

Chapter 3

Figure $3.1 \quad 130$

$\begin{array}{ll}\text { Figure } 3.2 & 131\end{array}$ 


\section{Introduction}

Andrew D. Gibbs

Before I begin Chapter 1, I would like to discuss with the reader the place of this document and my research in the world. It is not a groundbreaking study and does not add any great discoveries to the field of Ecology. I do however in these three chapters carefully fill in a blank space in our growing understanding of the biology of urban systems. Cities are the largest and most ecologically significant of all human creations, yet our understanding of them, and our willingness to modify them to support wildlife are meager. Our planet is at an inflection point. While catastrophic biodiversity loss is occurring, we compromise to support this destruction by building cities that are more supportive of cars than animals. This is where my work fits in. The world will overheat, mass extinction will continue. Most of the people in the world will resist any type of change that even moderately inconveniences them. I have used this project to identify a group of people, in one city, that is trying to buffer the pressing weight of the Anthropocene and try to determine if their efforts can have any impact at all.

It has been shown repeatedly that birds in a city respond to sources of variation in the urban landscape such as tree canopy cover (Palomino and Carrascal 2006, White et al. 2005, Melles et al. 2003), impervious surface (Minor and Urban 2009, Trollope et al. 2009), and human population density (Koh et al. 2006, Luck 2007). The impact of these vary depending on the natural climate and native vegetation of the city in question (Luck 2007). Portland, Oregon, is an excellent test of the ability of an actively 
managed urban wildlife matrix to support native species and discourage invasive ones. Human societies have the ability and resources to protect and restore former and degraded natural areas to near pristine conditions, even after years of industry and human use. Large scale restoration can be beneficial for wildlife (Ruiz-Jaén and Aide 2005, Martin et al. 2005), by providing critical resources. The United States has laws in place such as the Clean Air Act (US EPA 2015), Clean Water Act (US EPA 2013), and the Endangered Species Act (US FWS 2013) to govern use of public and private lands by regulating and outlining mitigation of environmentally destructive practices. In Portland land use is governed by these laws and local regulations to control sprawl and increase housing density with an urban growth boundary and infill requirements for existing neighborhoods (Portland 2016 2). Portland maintains heavily treed greenways with designed limited auto access to promote bicycle use (Portland 2016 1), has established tree cover minimums, and future increases in tree cover are identified as a goal (Portland 2007). In addition to managing the urban landscape for tree cover, Portland contains the largest urban forest in the United States (Forest Park 2025 ha), and dozens of smaller natural areas dispersed across the city.

Portland is growing rapidly, with the rest of the world population, and the future will test environmental ideals displayed in cities like this. However well a city manages its own land, much of the space in every city is residential and privately owned. In Portland there are standards for such things as minimum landscaped area, tree removal limitations, and vegetation maintenance guidelines. Other than these safety and tree preservation goals, yards are generally free from control of the city, and can be 
landscaped with anything from pure concrete, to highly invasive plants. This leaves the responsibility of providing usable wildlife habitat in neighborhoods in the hands of residential property owners. Urban yards and landscaping are generally terrible for wildlife (Bormann et al. 2001, Marzluff and Ewing 2001). Urban areas have low diversity and abundance of native invertebrates (Jones and Leather 2012) and birds (Chace and Walsh 2006), but suburban areas support diverse communities of birds (Blair 2004), which may be amplified by vegetation that matches the native habitat (Marzluff and Ewing 2001, Lerman and Warren 2011). This makes urban and suburban yards an important target for restoring habitat.

In chapter 1 I compare the distributions of birds in Portland to the distribution of urban habitat variables. In Chapter 2 I test the validity of the different certification levels in the Portland Backyard Habitat Certification Program. In Chapter 3 I test the ability of these yards to support wild bird populations. 


\section{Introduction References}

Blair, Robert. 2004. "The Effects of Urban Sprawl on Birds at Multiple Levels of Biological Organization." Ecology and Society 9 (5). https://doi.org/10.5751/ES-00688-090502.

Bormann, F. Herbert, Diana Balmori, and Gordon T. Geballe. 2001.

Redesigning the American Lawn: A Search for Environmental Harmony. Yale University Press.

Chace, Jameson F., and John J. Walsh. 2006. "Urban Effects on Native Avifauna: A Review." Landscape and Urban Planning 74 (1):46-69. https://doi.org/10.1016/i.landurbplan.2004.08.007.

Jones, Elizabeth L., and Simon R. Leather. 2012. "Invertebrates in Urban Areas: A Review." European Journal of Entomology 109 (4):463-78.

Koh, Chao-Nien, Pei-Fen Lee, and Ruey-Shing Lin. 2006. "Bird Species Richness Patterns of Northern Taiwan: Primary Productivity, Human Population Density, and Habitat Heterogeneity." Diversity and Distributions 12 (5):546-54. https://doi.org/10.1111/i.1366-9516.2006.00238.x.

Lerman, Susannah B., and Paige S. Warren. 2011. "The Conservation Value of Residential Yards: Linking Birds and People." Ecological Applications 21 (4): 1327-39. https://doi.org/10.1890/10-0423.1.

Luck, Gary W. 2007. "A Review of the Relationships between Human Population Density and Biodiversity." Biological Reviews 82 (4):607-45. https://doi.org/10.1111/i.1469-185X.2007.00028.x.

Martin, Leanne M., Kirk A. Moloney, and Brian J. Wilsey. 2005. “An Assessment of Grassland Restoration Success Using Species Diversity Components." Journal of Applied Ecology 42 (2):327-36. https://doi.org/10.1111/i.1365-2664.2005.01019.x.

Marzluff, John M., and Kern Ewing. 2001. "Restoration of Fragmented Landscapes for the Conservation of Birds: A General Framework and Specific Recommendations for Urbanizing Landscapes." Restoration Ecology 9 (3):28092. https://doi.org/10.1046/j.1526-100x.2001.009003280.x. 
Melles, Stephanie, Susan Glenn, and Kathy Martin. 2003. “Urban Bird Diversity and Landscape Complexity: Species-environment Associations Along a Multiscale Habitat Gradient." Conservation Ecology 7 (1). https://doi.org/10.5751/ES-00478-070105.

Minor, Emily, and Dean Urban. 2009. "Forest Bird Communities across a Gradient of Urban Development." Urban Ecosystems 13 (1):51-71. https://doi.org/10.1007/s11252-009-0103-1.

Palomino, David, and Luis M. Carrascal. 2006. "Urban Influence on Birds at a Regional Scale: A Case Study with the Avifauna of Northern Madrid Province." Landscape and Urban Planning 77 (3):276-90. https://doi.org/10.1016/i.landurbplan.2005.04.003.

Portland Oregon 2016 1. "Neighborhood Greenways." The City of Portland, Oregon. https://www.portlandoregon.gov/transportation/50518.

Portland Oregon 2016 2. "Residential Infill Project". The City of Portland, Oregon. http://www.portlandoregon.gov/bps/67728.

Ruiz-Jaén, María C., and T. Mitchell Aide. 2005. "Vegetation Structure, Species Diversity, and Ecosystem Processes as Measures of Restoration Success." Forest Ecology and Management 218 (1):159-73. https://doi.org/10.1016/i.foreco.2005.07.008.

Trollope, Samuel T., John G. White, and Raylene Cooke. 2009. "The Response of Ground and Bark Foraging Insectivorous Birds across an Urbanforest Gradient." Landscape and Urban Planning 93 (2):142-50. https://doi.org/10.1016/j.landurbplan.2009.06.013.

United States Environmental Protection Agency. 2013. "Summary of the Clean Water Act." Overviews and Factsheets. US EPA. February 22, 2013. https://www.epa.gov/laws-regulations/summary-clean-water-act.

United States Environmental Protection Agency.2015. "Clean Air Act Text." Collections and Lists. US EPA. May 29, 2015. https://www.epa.gov/clean-air-actoverview/clean-air-act-text.

United States Fish and Wildlife Service. 2013. "Endangered Species Program, Laws and Policies, Endangered Species Act." Accessed November 16, 2017. https://www.fws.gov/endangered/laws-policies/esa.html. 
White, John G., Mark J. Antos, James A. Fitzsimons, and Grant C. Palmer. 2005a. "Non-Uniform Bird Assemblages in Urban Environments: The Influence of Streetscape Vegetation." Landscape and Urban Planning 71 (2-4):123-35. https://doi.org/10.1016/i.landurbplan.2004.02.006. 


\section{Chapter 1}

Avian Community and Urban Habitat Analysis:

Total Avian Abundance Species Richness and Species Diversity Decline with Increasing Urbanization in Portland Oregon.

\section{Abstract}

In urban landscapes that have been managed to promote wildlife it is important for independent study of the fauna to understand, the frequently difficult to ascertain, impacts of this management. Applied and basic research on birds in cities is frequently restricted to parks and greenspaces, ignoring most of the urban matrix. In Portland Oregon this is no less the case, and we have limited knowledge of how Portland's avifauna is distributed across the city in relation to human population density, the built urban environment, or the urban living environment. To redress this situation, I used a randomized sampling of the birds of Portland, from 73 locations. At each point I conducted counts of birds in 2013 and 2014 to examine total avian abundance, species richness and diversity in relation to landcover and human demographic data. I used analysis of variance to compare avian community metrics and landscape structure among different regions of the city. I then used best subsets regression analysis to identify the primary determinants of variation in abundance, richness and diversity among survey points. Total avian abundance and diversity varied along common lines of 
urbanization, with greater abundance and more diverse samples in areas with less impervious surface, fewer humans and greater canopy cover. Species richness varied in a similar fashion, but much less, as urban tolerant species replaced urban intolerant ones while total number of species remained constant. Analysis of encounter rate of individual species among points identified tree cover as the primary correlate for most species, suggesting that efforts to increase tree cover in the landscape matrix will likely promote diverse avian communities.

\section{Introduction}

Urban landscapes can be managed to increase livability by wildlife (McPherson 1988, Paker et al. 2014, Säumel et al. 2016) through many means, including the establishment and/or restoration of natural areas (Andersson et al. 2014), street tree planting (Mason et al. 2007), yard restoration efforts, and water management (Brown et al. 2010). However, management for livability for humans is also important for wildlife (McPherson 1988, Semenza 2003). Cities and urban regions with limited vegetation are generally considered less livable because they experience higher temperatures (Keresztesová et al. 2014), greater air and water pollution (Denman et al. 2006, Janhäll 2015), more crime (Wolf and Mennis, 2012), and as consequence, property values are lower (Payton et al. 2008). The benefits of a treed urban landscape are considerable. Trees help to reduce particulate air pollution (Janhäll 2015), and pollution runoff 
(Denman 2006, Brown et al. 2010). They provide critical habitat for birds (Melles et al. 2003, White et al. 2005), and provide conditions that improve human physical and psychological well-being (Jackson 2003, Fuller et al. 2007, Berman et al. 2008).

While parks and greenspaces (P\&GSs) will almost certainly always be the central focus for management of urban areas for wildlife, it will also always be the case that most of the urban landscape will exist outside of a park system. The ecologies of these spaces are intimately connected to the cities in which they are imbedded because the ecological integrity of P\&GSs is in part dependent on the surrounding urban matrix (Tremblay and St. Clair 2011). The nature of the landscape outside of P\&GSs has the potential to influence dispersal for some species (Mason et al. 2007, Minor and Urban 2008), but for others also represents potentially habitable space that may support breeding populations (Fernández-Juricic 2000, Mason et al. 2007). Improving the quality of the matrix can potentially improve the ecological value of P\&GSs and increase livability of the matrix for birds and humans. However, understanding the dynamics of wildlife populations is difficult, and is especially challenging in urban areas because of the potential for P\&GSs to also act as ecological traps (Shipley et al. 2013).

The suitability of the larger urban matrix for birds and other wildlife is dependent on several features. The presence of tree canopy cover appears especially important (Melles et al. 2003, White et al. 2005, Palomino and Carrascal 2006, Tremblay and St. Clair 2011), but loss of space to impervious surface (i.e., roads, parking lots, etc.; Minor and Urban 2009, Trollope et al. 2009) is also critical. In addition, vegetation complexity (Hülsmann et al. 2015), and indirect effects of human population density 
(Koh et al. 2006, Luck 2007) have the potential to greatly affect wildlife. However, responses by birds to these landscape features vary among cities depending on climate and native vegetation (Chace and Walsh 2006, Luck 2007), and within each habitat type can be species-specific (Chace and Walsh 2006, Whittaker and Marzluff 2009). For instance, xeric-adapted bird species native to desert habitats tend to be excluded from irrigated urban and suburban habitats, while forest edge species of mesic habitats better tolerate urban landscapes (Chace and Walsh 2006, Lerman et al. 2012, Marzluff et al. 2016) if critical needs are met (Trollope et al. 2009). Those critical needs vary with the ecology and life history of each species. For example, many long-distance migrants and other forest interior species require trees for nesting (Tarvin and Garvin 2002, Crampton and Sedinger 2011) and foraging and feeding young (Oyugi and Brown 2003, Eggers et al. 2008, Becker et al. 2009, McDermott and Wood 2010), and as a consequence, are usually uncommon in urban settings (Marzluff 2001, but see Evans et al. 2011) where generalist and edge species dominate (Evans et al. 2011). Impervious ground surfaces can have particularly dramatic negative effects on habitat suitability for birds for many reasons including changing temperature dynamics (Luvall et al. 2000, Kalnay and Cai 2003), lowering abundance and diversity of arthropods (Jones and Leather 2012, Hülsmann et al. 2015), and preventing vegetation from becoming established.

The consequences of human population density on bird populations vary depending on each species' ability to cope with anthropogenic stress (Schlesinger et al 2008). Anthropogenic sources of food (Robb et al. 2008, Marzluff et al. 2012) and 
potential nest sites benefit some (Mainwaring 2015, Tomasevic and Marzluff 2017), but most species find it increasingly difficult to persist as human population density increases (Robb et al. 2008). Ground-nesting birds, for instance, tend to be underrepresented in urban environments (Hedblom and Söderström 2010), at least in part because of change in predator communities because of the introduction of nonnative predators, principally domestic cats (Felis silvestris; Heezik et al. 2010, Loss et al. 2013). Moreover, large predators tend to disappear in cities, whereas populations of mesopredators that often prey on the contents of bird's nests increase (Crooks and Soulé 1999, Fischer et al. 2012). However, in regions with a mix of housing types and abundant vegetation, it is possible to support healthy and diverse wild bird communities (Marzluff et al. 2012). Indeed, some populations are evolving to better handle the unique conditions found in highly urbanized environments (Partecke et al. 2006).

Portland, Oregon, USA $\left(45.52^{\circ} \mathrm{N}, 122.67^{\circ} \mathrm{W}, 15 \mathrm{~m}\right.$ above sea level), with a population of 639,863 people (US Census Bureau 2017), is the $26^{\text {th }}$ largest city in the United States. The total land area of the city is $375 \mathrm{~km}^{2}$, but the urban growth boundary currently encompasses an area of $1,407 \mathrm{~km}^{2}$. The population within the urban growth boundary is near 1.5 million people, and another 1 million people live in rural areas in the three counties of the Portland metropolitan area I used in this study. Portland's park system totals 4,733 ha, of which 3,200 ha constitute natural areas, $8.5 \%$ of Portland's area. The total proportion of Portland under park coverage, including developed parks (lawn dominated, but treed) is $12.6 \%$. Tree canopy cover in the city averages $26 \%$ and is split equally between private and public land (Portland 2012). 
Portland's regional management plans include the support of wildlife as a key goal (Portland Metro 2014). This is accomplished by purchasing new natural areas, creating regional wildlife corridors to connect wild areas, and reducing the area covered by impervious surface. The establishment of Portland's urban growth boundary (since 1978) may help to support wildlife by limiting loss of periurban natural areas and by promoting dense, but high quality urban living (Portland 2016 1). Additional efforts include building greenways for bicycle commuting that may also serve as wildlife corridors and aid in urban cooling, as tree planting efforts are prioritized to these cartraffic-restricted corridors (Portland 2016 2). Portland is also home to a unique and extensive backyard habitat restoration program (3000+ yards) overseen by the Audubon Society of Portland (ASP) (ASP 2016). Portland thus provides an excellent opportunity to evaluate the degree to which avian communities can utilize urban landscapes and persist outside of P\&GSs. I describe below the distribution of birds in Portland's urban landscape stratified by region within the city (see below). More specifically, I compare avian richness, abundance, and species diversity during the avian breeding season (May to July) to the distribution of tree canopy cover, human population density, and landcover by impervious surfaces, water and other vegetation. I then examine the response of individual species to the same set of human demographic and landscape variables. 


\section{Methods}

\section{The city landscape, point selection and survey protocol}

The Portland region has a mild to cool climate with an annual average temperature of

$12.4^{\circ} \mathrm{C}$, annual rainfall of $100 \mathrm{~cm}$ per year, and occasional snow totaling $10 \mathrm{~cm}$ per year. Rain is possible in any month, with an average of 154 days of rain, but little rain falls between July and September. Annual temperature ranges from near freezing in January, to $35^{\circ} \mathrm{C}$ in the summer months, (U.S. climate 2017). There are $390 \mathrm{~km}$ of rivers and streams in Portland, and the city is bordered and divided by two large rivers, the Columbia and the Willamette, which are both navigable and are international shipping waterways. The Willamette River divides Portland into east and west halves (Figure 1.1), while a major highway (Burnside Street) sets the traditional boundary between north and south. A northwest turn in the Willamette River further separates Northwest Portland (NW) from North Portland (NP; Figure 1.1). In addition to the physical separation caused by the river, the five regions differ in topography, history of settlement, and in demographics to produce somewhat distinctive neighborhoods. Southwest Portland (SW) and NW are the most topographically complex with NW being dominated by a $13 \mathrm{~km}$ ridge that ranges in elevation from $50 \mathrm{~m}$ to $330 \mathrm{~m}$. The ridge consists of several small natural areas, and Forest Park, which is a 2,025 ha undeveloped city park vegetated by mainly native conifers, hardwoods and associated understory vegetation. The neighborhoods of SW and NW Portland are integrated into the diverse 
complex topography surrounding this natural area. Moving eastward from Forest Park the landscape becomes relatively flat, with geology dominated by clay and gravel deposits from the Missoula floods (Trimble 1963, Benito and O'Connor 2003). This continues to the east of the Willamette river into North East Portland (NE), Southeast Portland (SE), and north into NP, all varying no more than $20 \mathrm{~m}$ in elevation throughout the regions, except for several buttes (180 m to $320 \mathrm{~m}$ ) formed by extinct volcanic cinder cones. The latter are now mostly forest covered and are dominant natural areas in these regions. NP is bordered by the Columbia River to the North, and the Willamette River to the South, and terminates at the confluence of the two rivers.

Multiple studies have shown that bird species richness and abundance vary along human demographic lines (Kinzig et al. 2005, Davis et al. 2012). In the United States residents of lower income areas tend to be non-white, are more likely to be immigrants, and have less education than individuals in more affluent neighborhoods (Houston et al. 2004, US Census 2010). Non-white and diverse neighborhoods also tend to be less vegetated (Hope et al. 2003, Martin et al. 2004, Landry and Chakraborty 2009), have fewer parks and natural areas (Wolch et al. 2005, Babey et al. 2007), but greater traffic (Houston et al. 2004) and lower bird species richness and diversity (McKinney 2008, Loss et al. 2009, Davis et al. 2012). Neighborhoods in SW are populated mainly by white, college-educated individuals with high incomes (Table 1.1). Human population density also tends to be the lowest in SW (Table 1.1). In contrast, among other regions of the city NP is tied for the highest proportion of non-white households, has the lowest proportion of college-educated individuals and ranks next to last for 
annual income (Table 1.1). NW is curious in that household annual income is the lowest of all regions, but proportion of college-educated individuals is high (Table 1.1). NW is gentrified and highly urbanized, attracting young educated individuals. Regions thus vary considerably in multiple ways that are likely to affect the distribution, diversity, and abundance of birds and I attempt to account for this in my analyses.

\section{Field methods}

Surveys of birds were conducted in the months of May, June, July and August of 2013 and 2014. To establish random survey points to characterize avifaunal use of the urban landscape I used the boundaries for the urban footprint of Portland and the five regions within the city described above as the boundary of my study area (Figure 1.1). The boundary encompassed all of Portland, OR, with small extensions into the adjacent municipalities of Lake Oswego and Gresham, OR. Perimeter length of the study area as measured in ArcMap10.2 (ESRI 2013) was 104,173 m and encompassed 66,017 ha (Figure 1.1). To select random points, I overlaid a grid on a map of the study area, with $500 \mathrm{~m} \times 500 \mathrm{~m}$ (25 ha) squares, and then randomly selected 100 squares with the restriction that they could not be in a body of water or in a natural area. The survey location within each selected square was determined by randomly choosing a number from 0-359 as a direction, and a number from 0.0 to 1.0 as a fractional distance from the center of the grid to its edge. The direction and distance were plotted from the center of each grid point to an approximate street address. Points that fell on major roads or highways were replaced with a new point chosen by repetition of the process described 
above. Random spatial distribution of the points was confirmed in ArcMap using the Average Nearest Neighbor tool and the Euclidean Distance method. As expected mean distance between points (1330.7 $\mathrm{m}$ ) did not differ from the observed mean distance (1309.5 $\mathrm{m}, \mathrm{z}$-score $0.291 \mathrm{p}=0.771)$. Points fell in a variety of urban habitat types including high and low density residential and industrial. I initially chose 100 points to survey, but this was reduced to 73 given time constraints or noise-related point exclusions (Appendix A, Table 1). Each point was surveyed either 3 or 4 times (256 total surveys). The number of randomly located survey points in each region (NP, NW, SW, $\mathrm{SE}, \mathrm{NE}$ ) differed (Table 1.1) because regions differed in size.

The random sites were sampled in conjunction with a simultaneous backyard habitat study that is reported elsewhere (Gibbs 2018 1, Gibbs 2018 2). Surveys were conducted in early mornings in 2013 (5 June through 24 July) and 2014 (May 25 to August 21). Usually 12, but between 8 and 16 points inclusive of yards and random points were surveyed each morning; 0 to 12 of the sites were random points on any given day. Points were reached by car, and travel time between points required that all surveys within a day take place in one region of the city. However, all regions were sampled every week of the study. The sequence of surveys along a route varied among survey dates so that all points were sampled at multiple times of the morning.

For each survey I used a variable circular plot method (Reynolds et al. 1980) to conduct a 10 min count of all birds heard or seen within a 50 m circle centered on the survey point. Upon arriving at each point, I waited 2 minutes before beginning each count. Care was taken to not count the same individual twice, and multiple records of 
the same species that could not be assigned to different individuals were counted as one individual. If a bird was encountered but simply flew over the $50 \mathrm{~m}$ circle it was not counted. Rain can be sporadic throughout the day in spring and early summer in Portland; some surveys were thus unavoidably conducted on days when it rained. However, I never made counts when precipitation was above a slight mist, and always waited 10 min before initiating a count after a period of rain above a slight mist. In contrast, I avoided or delayed sampling some points because of excessive sound generated by high traffic, leaf blowers or other heavy equipment that made detection of sounds out to $50 \mathrm{~m}$ difficult. Some sites in industrial and shipping areas were sampled specifically on weekends to minimize disturbance that would limit detections.

\section{Quantification of predictors of avian distribution}

I used publicly available data on tree canopy cover, land cover types, and abundance of humans to characterize the landscape surrounding each survey point. ArcGIS 10.2 (ESRI 2013) and a shape file containing the locations of survey points was used for processing all spatial data. The "buffer" tool was used to create $150 \mathrm{~m}$ and $500 \mathrm{~m}$ radius circular buffers around each point to allow examination of the effects of local and larger scale landscape features on birds. To assign tree canopy cover values to the buffers a raster file developed from LIDAR data by Portland Metro (Metro 2016) was reclassified to canopy/no canopy values of 1 and 0 , respectively, with the "reclassify" tool. The number of pixels of each type ( 1 or 0 ) was counted using the "tabulate area 2 " tool, this was then converted to a percent of the total number of pixels in each circular buffer, yielding 
percent cover. Using a raster file from the United Sates Environmental Protection Agency EnviroAtlas (US EPA 2015), values for landscape cover types, including impervious surface, soil or bare ground, tree or forest, grass and herbaceous, woody wetlands, and emergent wetlands were assigned to the $150 \mathrm{~m}$ and $500 \mathrm{~m}$ buffers using the "tabulate area 2" tool, and percent landcover of each type was calculated from pixel counts. There was no wetland of either type in the study area; these categories were therefore not used further. The tree and forest category from the EPA data was highly correlated with LIDAR estimates of tree canopy cover $(r=0.967, \mathrm{n}=73, P<0.001)$. I chose to use the higher resolution LIDAR canopy data in my analyses. Tree or forest and grass were summed to create a new variable called Total Green. The human census block data file from Portland Metro was clipped to match the study area, converted to raster, and using the "zonal statistics as table" function, population values were added to the circular buffers. This resulted in a population density raster that I used to calculate the number of people living within each $150 \mathrm{~m}$ and $500 \mathrm{~m}$ radius circle.

\section{Statistical analyses}

I used STATISTIX and JMP for my analyses. Statistics are given as mean \pm SE, $n$, and I considered results with $P \leq 0.05,0.10 \geq P>0.05$, and $P>0.10$ to be significant, marginally nonsignificant, and nonsignificant, respectively. I summarized the survey data for each point by calculating total bird abundance (number of individuals of all species), species richness (number of species per survey), and species diversity (Shannon-Wiener Index). These summary statistics for each survey point were calculated with the average 
values of the pooled survey data of each point. At the level of species, I calculated encounter rate as the proportion of the 3 or 4 surveys at each site in which a species was detected.

Survey points were compared among regions of the city for differences in habitat composition, human population density, and avian survey results using analysis of variance (ANOVA) for both the $150 \mathrm{~m}$ and $500 \mathrm{~m}$ diameter circles. I then performed separate principal component analyses (PCA) to assess landscape structure for the local $(150 \mathrm{~m})$ and larger landscape $(500 \mathrm{~m})$ circular areas using population density and percent of land covered by tree canopy, impervious surface, soil or bare ground, grass or herbaceous vegetation, and water. Total green space was not included as it was highly correlated with the three variables that were summed to obtain its value. I then used best subsets regression analysis to identify probable determinants of variation in total avian abundance, species richness, and species diversity by combining, in a hierarchical manner, individual landscape variables and the first three eigenvectors from the PCAs (see below) of the $150 \mathrm{~m}\left(\mathrm{PC} 1_{150}, \mathrm{PC} 2_{150}\right.$, and $\left.\mathrm{PC} 3_{150}\right)$ and $500 \mathrm{~m}$ radius circles $\left(\mathrm{PC}_{1500}\right.$, PC2 500 , and $P\left(3_{500}\right)$. Individual variables were included to identify particularly important variables, whereas PC axes were included to account for the possibility that avian responses to habitat integrated effects of multiple variables simultaneously. I began by conducting, at the local level, best subsets regression analyses of the individual landscape variables, and then just the three PC axes from that level. I retained the competitive models $(\triangle \mathrm{AICC} \leq 2)$ from both analyses for later identification of top models. Uninformative models (Arnold 2010) were not retained, nor were any models in which 
variance inflation factors exceeded 9.0. Next, I removed the two most important landscape variables contributing to $\mathrm{PC} 1_{150}$ from the set of predictor variables, replaced them with $\mathrm{PC}_{150}$, and performed a third analysis that combined individual landscape variables with the most important composite landscape descriptor $\left(\mathrm{PC}_{150}\right)$. Competitive models were retained. I repeated the process for $P C 2_{150}$ and $P C 3_{150}$ (i.e., the two top variables contributing to each were removed, replaced by the PC axes, and reanalyzed by combining individual landscape variables with PC axes). The entire process was repeated at the larger landscape scale. Results showed that all three response variables (total abundance, species richness and diversity) varied more strongly with variables measured at the local $(150 \mathrm{~m})$ scale. Thus, to evaluate the potential influence of factors operating at both the local and larger geographic scale, I combined the two variables that emerged (for each response variable) as the strongest predictors at the local scale with landscape variables from the larger geographic scale (minus the two landscape variables at the larger scale that corresponded to the two variables included at the local scale) along with $\mathrm{PC}_{500}, \mathrm{PC}_{500}$ and $\mathrm{PC}_{500}$. The competitive models that emerged from this last set of analyses were combined with the competitive models retained from the previous analyses. From the total set of models retained as competitive at each of their respective levels I identified the one with the lowest AICc and subtracted that value from the AICC of all models. $\triangle \mathrm{AIC}$ from this last step led to the retention of $\leq 3$ models for eventual description of the main determinants of landscape variation in total avian abundance, species richness and species diversity. 
The responses of individual species, measured as encounter rate at each survey point (number of surveys encountered/total number of surveys), to the same set of predictor variables was examined through correlation analysis. I restricted my analysis to species that were encountered at a minimum of $10.0 \%$ of points. For this subset I also identified the apparent minimum canopy cover required for the presence of a species (or absence for non-forest species) in the $150 \mathrm{~m}$ buffer surrounding each point. Identical analyses were performed for the $500 \mathrm{~m}$ buffer landscape, but because results at the two scales were qualitatively and quantitatively nearly identical I only report the results for the $150 \mathrm{~m}$ analysis. 


\section{Results}

Across the city, impervious surfaces covered nearly half the ground surface $(47.2 \pm$ $2.41 \%$; range $=3.2 \%$ to $95.1 \%)$, followed distantly by tree $(25.9 \pm 2.04 \%$; range $=0.4 \%$ to $91.2 \%)$ and grass/herbaceous cover $(25.1 \pm 1.44 \%$; range $=1.4 \%$ to $58.4 \%)$. Water $(1.1 \pm$ $0.69 \%$; range $=0.0 \%$ to $37.6 \%)$ and bare ground $(0.03 \pm 0.03 \%$; range $=0.0 \%$ to $1.8 \%)$ accounted for little surface cover. On average, nearly 19 people per hectare lived in the $150 \mathrm{~m}$ radius circles surrounding survey points $(18.8 \pm 1.72$ individuals/hectare; range $=$ 0 to 64.3$)$. This is approximately 1.2 million people in the 66,017 hectare study area, close to the census value.

City regions varied considerably in nearly all landscape features (Table 1.1). Canopy cover and impervious surfaces varied in approximate inverse fashion, with the highest canopy cover and lowest impervious surface cover occurring in the SW, and the reverse in NP. Grass/herbaceous cover were very low in NP and highest in SE.

Population density did not differ significantly among regions; however, in SW, in concert with its high canopy cover and large total green space, population density was lowest SW (Table 1.1). Even though the smaller and more local area sampled by the $150 \mathrm{~m}$ radius circle represented only $9 \%$ of the area sampled by the $500 \mathrm{~m}$ diameter circle, results of the landscape analysis conducted using data from the $150 \mathrm{~m}$ and $500 \mathrm{~m}$ circle units yielded nearly identical qualitative and quantitative results (Table 1.1). 


\section{Principal component analysis of landscape variables}

At the 150 m distance the first three eigenvectors (i.e., principal components [PC1, PC2 and PC3]) explained 75\% of the variation in landscape structure (Table 1.2). PC1 accounted for nearly a third of the variation and described a gradient of sites that contained high impervious surface cover and low cover by both tree canopy and herbaceous vegetation cover (negative scores). That changed gradually to sites with the opposite combination of low impervious cover and abundant canopy and herbaceous cover (positive scores). PC1 thus represented an urbanization gradient with negative scores being most urbanized. PC2 and PC3 each accounted for about $21 \%$ of the variation in landscape structure (Table 1.2). PC2 was a contrast of sites with little water or grass/herbaceous vegetation cover but abundant canopy cover (negative scores) with sites having abundant water and grass/herbaceous cover but little canopy cover. Water cover came primarily from the two rivers that dissect Portland. PC3 was essentially a gradient of increasing population density combined with increasing surface cover by soil/bare ground (Table 1.2). PC1 and PC2 differed among regions, but PC3 did not (Table 1.1). However, because of the small sample size from NW, I compared regions with and without NW Portland included. The effect of removing the NW was to increase the strength of the statistical differences among sites for canopy cover, impervious surface, total green, and PC1 (Table 1.1). In contrast, differences among regions in grass/herbaceous and PC2 were no longer significant, while differences along PC3 tended to increase (Table 1.1). 
The PCA of data collected at $500 \mathrm{~m}$ differed in several respects from the analysis of the smaller area. Canopy cover and impervious surface remained the primary contributors to variation along PC1, but grass/herbaceous vegetation cover was no longer a contributor (Table 1.2). PC1 nonetheless still described an urbanization gradient with positive scores representing the least urbanized sites; the SE and SW regions scored significantly higher on PC1 than NP and NE. PC2 and PC3 changed considerably; PC2 now represented a gradient of high water cover and low population density (negative scores) to low water cover and high population density (positive scores). PC2 did not differ among regions (Table 1.1). PC3 described sites with low canopy cover but abundant grass/herbaceous vegetation cover (negative scores) to sites having moderate tree cover but abundant cover by grasses and/or herbs (Table 1.2). The SW had significantly lower scores on PC3 than all other regions except NP and NW. East Portland (both NE and SE) had higher scores on PC3 than SW, indicating that east Portland had an abundance of grass/herbaceous vegetation cover compared to other regions (Table 1.1).

\section{Avian abundance, richness, and species diversity}

144 surveys at 73 locations were carried out in 2013, and 112 surveys at 73 locations in 2014. 48 and 55 bird species were detected in 2013 and 2014, respectively; of these, 52 were native and 3 were exotic. Avian abundance averaged $11.3 \pm 0.45$ birds/count ( $N=$ 73) and was generally highest in the southern portions of the city (Table 1.3). Richness did not differ among regions, and nearly four bird species were detected during an average count ( $3.7 \pm 0.13$ species, $N=73$ ). The Shannon-Wiener diversity index 
averaged $2.18\left( \pm 0.046 \mathrm{H}^{\prime}, \mathrm{N}=73\right)$, but ranged from a low of 0.95 to a high of 2.81 . Locations in the SW supported the greatest abundance, richness, and diversity, followed by the SE, while the lowest values for these being NW sites. Reanalysis without the limited number of NW sites resulted in the loss of statistical significance of the difference in abundance among regions, but a slightly stronger statistical difference in species diversity (Table 1.3); NE sites were significantly less diverse than sites in the SE and SW.

Univariate comparisons of total avian abundance, species richness, and species diversity in relation to human population density, landscape variables, and the first three eigenvectors from the PCAs of the $150 \mathrm{~m}\left(\mathrm{PC}_{150}, \mathrm{PC} 2_{150}\right.$, and PC3 150$)$ and $500 \mathrm{~m}$ $\left(\mathrm{PC}_{500}, \mathrm{PC} 2_{500}\right.$, and $\left.\mathrm{PC} 3_{500}\right)$ sample areas suggested that response variables tended to be more strongly associated with local landscape structure than with the larger landscape sampled by the $500 \mathrm{~m}$ diameter circle. At least $50 \%$ of the predictor variables exhibited stronger relationships (at $P \leq 0.10$ ) with the response variables at the local rather than at the larger geographic scale (Table 1.4). Moreover, in all cases involving total avian abundance and species diversity, correlation coefficients of the same predictor with a response variable at the two geographic scales were stronger at the local level (Table 1.4). At both geographic scales, the strongest relationship with species diversity was a decline with increasing impervious surface cover, followed by an increase with total green space (Table 1.4). This seemed to arise mainly from the existence of the same relationships with average total abundance, but also to a lesser extent, species richness (Table 1.4). Overall, variation in species richness exhibited the 
weakest relationships with landscape composition and human population density (Table 1.4).

The hierarchical analysis of total avian abundance from the local landscape, larger landscape, and combined analyses yielded only a single competitive model (Table 1.5), and it accounted for $30 \%$ of the variation in abundance. Abundance declined with increasing impervious surface cover, soil/bare ground and human population density, but increased as the total green surface increased and with higher $\mathrm{PC}_{500}$ (high canopy cover and lower impervious cover; i.e., less urbanization).

Analysis of species richness yielded many models (Table 1.6), perhaps reflecting the lack of a single strong correlate of richness with any variable (Table 1.4). In the final analysis, however, only two models were competitive and under a quarter of the variation in richness was accounted for (Table 1.6). More species tended to be found in locations with both elevated levels of grass/herbaceous vegetation and canopy cover, at sites with high scores on $\mathrm{PC}_{1500}$ (high canopy cover and low impervious surface cover), and low PC3 500 (high canopy cover but low grass/herbaceous vegetation cover). Analysis of species diversity yielded an intermediate (11) set of models. All models were competitive $(\Delta \mathrm{AICC} \leq 2)$ at their respective level, but when referenced against what was ultimately the top model, only three models merited interpretation (Table 1.7). Species diversity consistently declined as the local landscape was increasingly covered by impervious surface and bare ground/soil, and they alone accounted for over a third of the variation in species diversity. PCA2 500 also appeared in all three top models, suggesting a decline in species diversity with increasing human 
population density and decreasing water cover (i.e. proximity to rivers). There were indications that species diversity declined with increasing $\mathrm{PC}_{500}$ and grass/herbaceous cover but rose with increasing canopy cover (Table 1.7). However, confidence intervals of only the first three variables excluded zero (Table 1.8), and together they accounted for $38.6 \%$ of the variation in species diversity.

\section{Encounter rates of individual species}

Twenty-five species met the minimum requirement of being encountered 5 times for analysis of encounter rate, and of these, 23 were resident species. The sole NearcticNeotropical migrant was the Black-headed Grosbeak (scientific names are given in Table 1.9). Encounter rates of four species were unrelated to canopy cover, impervious surface, human population density, and the top three eigenvectors from the PCA of habitat variables from the $150 \mathrm{~m}$ buffer. Encounter rate of 11 of the remaining 21 species exhibited their strongest relationship with tree canopy cover, and of these, only the White-crowned Sparrow and the non-native House Sparrow and European Starling exhibited negative associations with increasing canopy cover (Table 1.9). The Blackcapped Chickadee was the only species of the 11 to not exhibit a minimum canopy cover requirement of at least $10 \%$. In contrast, Chestnut-backed Chickadees required at least $30 \%$ canopy cover, which was exceeded only by Stellar's Jay (>40\%) and Brown Creeper $(>50 \%)$.

Human population density was the second most important correlate of encounter rate. For the seven of the 21 species with at least one marginally significant 
correlation with the predictor variables, responses were split nearly equally between negative (3) and positive (4) associations (Table 1.9). Two of the four species exhibiting positive associations with population density were the two smallest species in my analysis (Anna's Hummingbird and the Bushtit; Tables 1.9 and 1.10) while the two others (California Scrub-Jay and House Finch) are known to be positively associated with humans (Rodewald 2015). Of the three remaining species exhibiting at least one marginally significant relationship with the predictor variables, Song Sparrows were less frequently encountered at sites with high impervious ground cover, Bewick's Wren were more often encountered in less urbanized sites (positive score on PC1), and Blackheaded Grosbeaks were more common where the buffer included riparian sites (i.e., abundant water) and abundant grass/herbaceous cover.

\section{Discussion}

The abundance and diversity of birds varied significantly across the Portland urban landscape, and both declined with increasing urbanization. By contrast, species richness did not show nearly as dramatic a response to urbanization. Analyses of abundance and diversity indicated that impervious surface, which represents a complete lack of habitat, was the primary driver for the decline of both with urbanization. As this study was conducted entirely within an urban matrix, the species that I detected must have some level of commensal association with, or tolerance of, humans. By way of confirmation, it should be noted that only one Nearctic-Neotropical migrant was detected sufficiently 
often to be included in my analyses. Tolerance of impervious surface varied considerably even among the remaining mainly resident species; this is presumably the cause for the decline in diversity from areas of low to high urbanization. Areas with little impervious surface supported a diverse group of generally non-social species that employ multiple foraging strategies (Tables 1.9, 1.10). For example, the Spotted Towhee and Brown Creeper are both strongly associated with trees and appear to avoid humans and impervious surfaces (Tables 1.9). In contrast, more gregarious and invasive species are typical of more open areas with large parking lots and lawns (Table 1.9, 1.10).

While species diversity responded subtly to many variables, abundance was more strongly impacted solely by impervious surface. Areas with low impervious surface have elevated levels of canopy cover $\left(\mathrm{PC}_{150}\right.$ and $\left.P C 1_{500}\right)$, and while diversity increased in areas of high levels of canopy cover, abundance did not. This was because tree cover excludes the same gregarious and invasive species that are drawn to more open areas. As a consequence, the number of individuals did not dramatically change, but the number of species increased as additional vertical habitat was added with increasing tree cover. Surprisingly, there was little response by abundance, richness or diversity to human population density, possibly because of the even distribution of humans in Portland. However, population density was the second most frequent predictor of the encounter rate of individual species, but with an approximately even split between negative and positive associations that may have canceled the effect of human population density when bird community metrics were examined. While avian 
abundance and species diversity responded to urbanization, the absolute number of species showed minor change across the study area and responded (negatively) to impervious surface. The lack of substantial variation in richness was apparently since species replaced one another as they responded to urbanization (Table 1.9).

While species richness was weakly impacted by impervious surface and tree canopy cover, species diversity showed a much stronger response. Areas with higher levels of canopy cover and low impervious surface not only had more species, there were more individuals of the species present, and no human commensal species (e.g., American Crows, House Sparrows, and European Starlings) that dominate other parts of the city (Tables 1.9).

The negative response of birds in Portland to urbanization is consistent with the body of research on bird distributions in cities (Chace and Walsh 2006, Evans 2009). Cities tend to act as filters favoring a few species that can thrive in large numbers, completely or partially excluding other species. The response to urbanization by birds in Portland, and responses found in other cities show a pattern of lower abundance and lower species diversity in areas of high urbanization and increases in avian abundance and diversity in moderately urbanized areas (Clergeau et al. 1998, Melles 2003, White et al. 2005, Ortega-Álvarez and MacGregor-Fors 2009) that have higher levels of tree cover, lower concentration of paved surfaces, and moderate human population levels. Cities are not going away; to the contrary, the human population will continue to grow and will likely exclude increasingly more species. In this environment we must use what evidence we have to manage cities and attempt to buffer mass extinction. Given the 
overriding importance of tree canopy cover to many of the species found in the Portland landscape (Table 1.9), prioritization of tree planting efforts, along with pavement reduction and development of mixed housing types to reduce dense urban centers, may be the best model for stabilizing wildlife diversity in mesic cities.

Previous research in other cities has demonstrated that bird distributions in urban environments vary in multiple and complex ways. Some of the observed patterns, such as correlations with human demographics, are not useful in determining habitat variables important to birds but are important for identifying weaknesses in urban habitat management. Multiple studies have shown correlations among birds and human demographic factors such as income, race, and education. What increasingly appears to be revealed is a lack of attention to wildlife, human living conditions, and ecological concerns, in lower income regions of every city in the United States (Melles 2005, Landry and Chakraborty 2009). In my study SW Portland not only had the highest level of tree cover (45\%), and lowest land area covered by impervious surface (34\%), it also had the lowest human population density, highest level of education, and lowest human ethnic diversity of any of the other four Portland regions. The area is dominated by large homes, with large lots, and fewer multifamily buildings than the other regions (Table 1.1). The complex topography of this area is also relatively unique when compared to the rest of city, and the private lands situated with steep back lots with grades which protect much of the land from development. This desirable environment leads to high housing prices that limit buyers to those with higher incomes than the rest of Portland $(\$ 70,949$ per year, Table 1.1) vs. $\$ 51,000$ for the US as a whole. These residents tend to 
be more highly educated and predominantly white $(90 \%)$ than the mean for either Portland (74\%) or the United States (63\%). Livability for humans and habitat suitability for animals are linked, and both can be addressed by targeting neighborhoods for habitat improvement that have high population densities and ethnic diversity but low incomes. This should include adding street trees, bioswales and native shrubs along roadways across all regions of the city. Pavement from vacant public lots should be removed and replaced with native vegetation and parks. Large private development should include requirements for increasing habitat volume with smaller lawn sizes, ample shrub planting, bioswales, and a minimum of $20 \%$ tree cover. Attention must also be given to policies and education to reduce access to the outdoors by cats, as they can reduce bird population sizes below sustainable levels (Heezik et al. 2010, Loss et al. 2013, Bartos-Smith et al. 2016). Cities can be rich and full of avian life, but only with careful and competent management. 


\section{Chapter 1 Figures and Tables}

Figure 1.1 Study area for sampling of birds, and habitat variables from random locations (green circles) and yards (blue circles). The orange line circumscribing a pink region indicate the study area. Portland, OR is outlined by a thick black line and is bordered by Vancouver WA, Gresham OR, Lake Oswego OR, Tigard OR, and Beaverton OR (clockwise from the north). The Willamette River divides Portland into east and west halves, while Burnside Street separates north from south Portland. A northwest turn in the Willamette River separates Northwest Portland (NW) from North Portland (NP). Green lines below follow these landmarks and divide the indicated regions NW, NP, Northeast Portland (NE), Southeast Portland (SE), and Southwest Portland (SW).

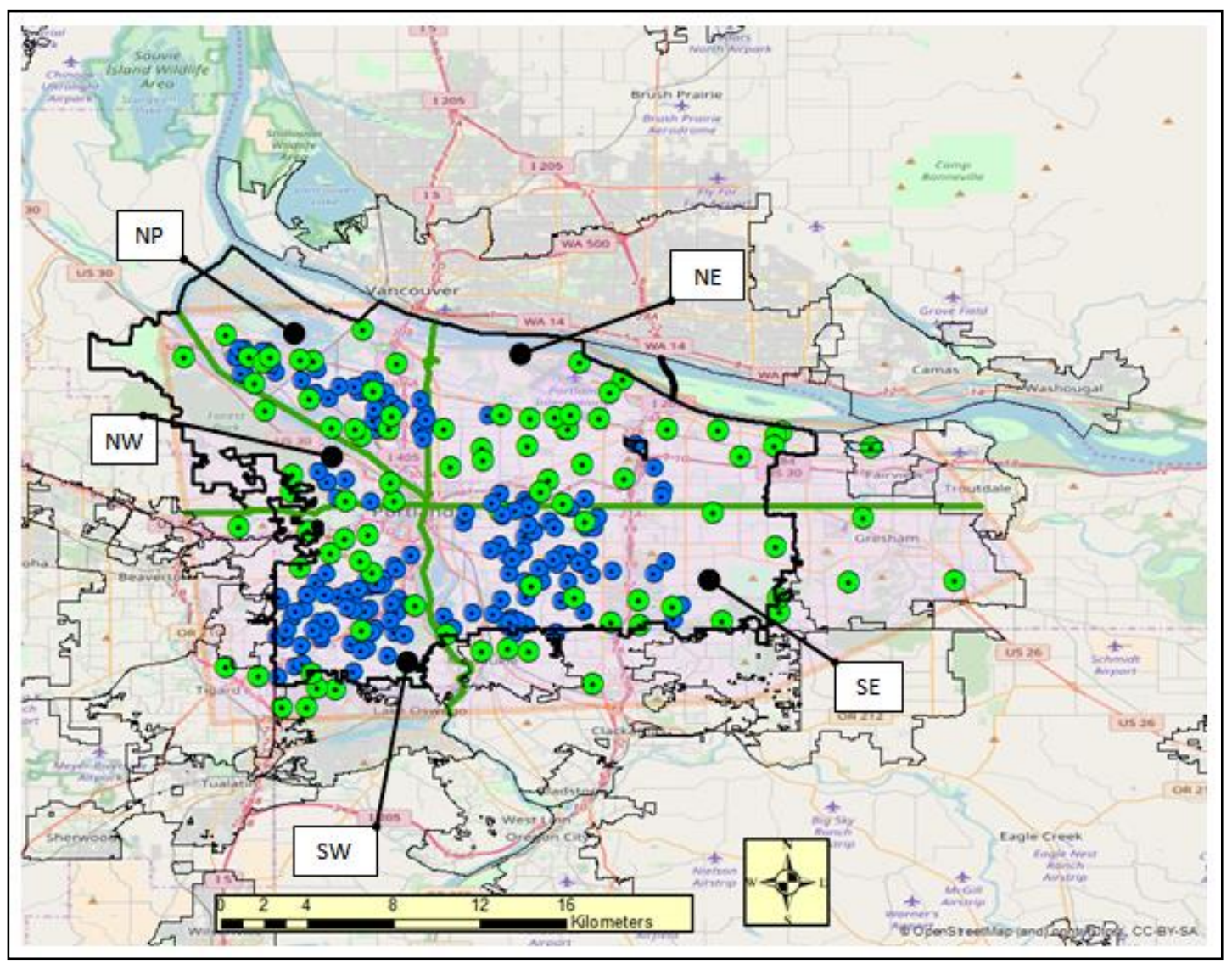


Table 1.1. Comparison of the landscape composition and human demographics of Portland, OR, regions. Portland is divided into 5 geographic regions, North (NP), Northeast (NE) Northwest (NW), Southeast (SE), and Southwest (SW). Regions are separated from each other by a large highway and the Willamette River. Numbers in parentheses following region name are the number of samples for random points used to collect both bird and landscape/population data within each region.

Comparisons of means of landscape data were made using analysis of variance with $\left(F[P]^{1}\right)$ and without $\left(F[P]^{2}\right)$ the NW region included in the analysis. Results are reported for samples collected from both $150 \mathrm{~m}$ and $500 \mathrm{~m}$ diameter circles centered on each sample point.

\begin{tabular}{|c|c|c|c|c|c|c|c|}
\hline & NP (15) & NE (22) & NW (4) & SE (20) & SW (12) & $F(P)^{1}$ & $F(P)^{2}$ \\
\hline $\begin{array}{l}\text { Income } \\
\text { (\$/yr) }\end{array}$ & 51,034 & 55,393 & 41,848 & 53,340 & 70,949 & ---- & ---- \\
\hline White \% & 70 & 70 & 80 & 80 & 90 & ---- & ---- \\
\hline College \% & 19 & 30 & 51 & 34 & 59 & ---- & ---- \\
\hline \% Poverty & 15.0 & 12.4 & 15.5 & 10.9 & 6.8 & $\begin{array}{l}--- \\
\end{array}$ & $\begin{array}{l}--- \\
\end{array}$ \\
\hline $\begin{array}{l}\text { Total area } \\
\text { (ha) }\end{array}$ & 3970 & 10550 & 1820 & 9660 & 5470 & ---- & ---- \\
\hline \multicolumn{8}{|c|}{$150 \mathrm{~m}$ sample unit } \\
\hline $\begin{array}{l}\text { Canopy } \\
(\%)\end{array}$ & $\begin{array}{c}18.8 \\
(2.38)\end{array}$ & $\begin{array}{c}20.3 \\
(2.30) \\
C\end{array}$ & $\begin{array}{c}39.4 \\
(20.82)\end{array}$ & $\begin{array}{c}29.9 \\
(2.96)\end{array}$ & $\begin{array}{c}46.0 \\
(4.76)\end{array}$ & $\begin{array}{c}7.89 \\
(0.000)\end{array}$ & $\begin{array}{c}14.09 \\
(<0.001)\end{array}$ \\
\hline $\begin{array}{l}\text { Impervious } \\
(\%)\end{array}$ & $\begin{array}{c}58.2 \\
(4.26)\end{array}$ & $\begin{array}{c}50.3 \\
(4.09)\end{array}$ & $\begin{array}{c}55.7 \\
(22.92)\end{array}$ & $\begin{array}{c}42.0 \\
(3.70)\end{array}$ & $\begin{array}{c}33.7 \\
(4.26)\end{array}$ & $\begin{array}{c}3.39 \\
(0.014)\end{array}$ & $\begin{array}{c}5.40 \\
(0.002)\end{array}$ \\
\hline $\begin{array}{l}\text { Soil/bare } \\
\text { (\%) }\end{array}$ & $\begin{array}{c}0.00 \\
(0.000)\end{array}$ & $\begin{array}{c}0.09 \\
(0.082)\end{array}$ & $\begin{array}{c}0.00 \\
(0.000)\end{array}$ & $\begin{array}{c}0.04 \\
(0.031)\end{array}$ & $\begin{array}{c}0.00 \\
(0.000)\end{array}$ & $\begin{array}{c}0.52 \\
(0.721) \\
\end{array}$ & $\begin{array}{c}0.62 \\
(0.602)\end{array}$ \\
\hline $\begin{array}{l}\text { Grass/herb } \\
\text { (\%) }\end{array}$ & $\begin{array}{c}22.2 \\
(2.96)\end{array}$ & $\begin{array}{c}26.7 \\
(2.39)\end{array}$ & $\begin{array}{c}5.8 \\
(2.96)\end{array}$ & $\begin{array}{c}30.0 \\
(2.54)\end{array}$ & $\begin{array}{c}23.9 \\
(3.56)\end{array}$ & $\begin{array}{c}4.23 \\
(0.004)\end{array}$ & $\begin{array}{c}1.52 \\
(0.217)\end{array}$ \\
\hline
\end{tabular}




\begin{tabular}{|c|c|c|c|c|c|c|c|}
\hline Water (\%) & $\begin{array}{c}2.32 \\
(2.267)\end{array}$ & $\begin{array}{c}1.83 \\
(1.703)\end{array}$ & $\begin{array}{c}0.00 \\
(0.005)\end{array}$ & $\begin{array}{c}0.02 \\
(0.016)\end{array}$ & $\begin{array}{c}0.12 \\
(0.120)\end{array}$ & $\begin{array}{c}0.52 \\
(0.722)\end{array}$ & $\begin{array}{c}0.62 \\
(0.605)\end{array}$ \\
\hline $\begin{array}{l}\text { Total } \\
\text { green (\%) }\end{array}$ & $\begin{array}{c}39.4 \\
(4.72) \\
\end{array}$ & $\begin{array}{c}47.7 \\
(3.57) \\
\end{array}$ & $\begin{array}{c}44.3 \\
(22.92)\end{array}$ & $\begin{array}{c}57.9 \\
(3.69) \\
\end{array}$ & $\begin{array}{c}66.2 \\
(4.21) \\
\end{array}$ & $\begin{array}{c}4.27 \\
(0.004)\end{array}$ & $\begin{array}{c}7.07 \\
(<0.001)\end{array}$ \\
\hline $\begin{array}{l}\text { Density } \\
\text { (\#/ha) }\end{array}$ & $\begin{array}{c}19.0 \\
(4.26) \\
\end{array}$ & $\begin{array}{c}18.1 \\
(3.42) \\
\end{array}$ & $\begin{array}{c}19.9 \\
(15.17) \\
\end{array}$ & $\begin{array}{c}21.3 \\
(2.46) \\
\end{array}$ & $\begin{array}{c}15.4 \\
(2.80) \\
\end{array}$ & $\begin{array}{c}0.31 \\
(0.870) \\
\end{array}$ & $\begin{array}{c}0.47 \\
(0.702) \\
\end{array}$ \\
\hline PC1 & $\begin{array}{c}0.774 \\
(0.335)\end{array}$ & $\begin{array}{c}0.272 \\
(0.256)\end{array}$ & $\begin{array}{c}0.630 \\
(1.437)\end{array}$ & $\begin{array}{c}-0.443 \\
(0.253)\end{array}$ & $\begin{array}{l}-0.940 \\
(0.258)\end{array}$ & $\begin{array}{c}4.07 \\
(0.005)\end{array}$ & $\begin{array}{c}6.24 \\
(0.001)\end{array}$ \\
\hline PC2 & $\begin{array}{c}0.198 \\
(0.291)\end{array}$ & $\begin{array}{c}0.399 \\
(0.319)\end{array}$ & $\begin{array}{c}-1.250 \\
(0.364)\end{array}$ & $\begin{array}{c}0.011 \\
(0.135)\end{array}$ & $\begin{array}{l}-0.580 \\
(0.227)\end{array}$ & $\begin{array}{c}3.06 \\
(0.022)\end{array}$ & $\begin{array}{c}0.58 \\
(0.631)\end{array}$ \\
\hline PC3 & $\begin{array}{l}-0.003 \\
(0.273)\end{array}$ & $\begin{array}{c}0.210 \\
(0.281)\end{array}$ & $\begin{array}{c}-0.547 \\
(0.988)\end{array}$ & $\begin{array}{c}0.233 \\
(0.163)\end{array}$ & $\begin{array}{l}-0.587 \\
(0.249)\end{array}$ & $\begin{array}{c}1.53 \\
(0.203)\end{array}$ & $\begin{array}{c}1.89 \\
(0.141)\end{array}$ \\
\hline \multicolumn{8}{|c|}{$500 \mathrm{~m}$ sample unit } \\
\hline $\begin{array}{l}\text { Canopy } \\
(\%)\end{array}$ & $\begin{array}{c}18.0 \\
(1.88)\end{array}$ & $\begin{array}{c}20.5 \\
(1.58) \\
\end{array}$ & $\begin{array}{c}40.7 \\
(20.9) \\
\end{array}$ & $\begin{array}{c}29.7 \\
(3.20)\end{array}$ & $\begin{array}{c}44.9 \\
(4.00)\end{array}$ & $\begin{array}{c}8.91 \\
(0.001)\end{array}$ & $\begin{array}{c}16.91 \\
(0.001)\end{array}$ \\
\hline $\begin{array}{l}\text { Impervious } \\
(\%)\end{array}$ & $\begin{array}{c}55.4 \\
(3.24) \\
\end{array}$ & $\begin{array}{c}48.6 \\
(2.61) \\
\end{array}$ & $\begin{array}{c}49.1 \\
(19.53) \\
\end{array}$ & $\begin{array}{c}40.3 \\
(3.43) \\
\end{array}$ & $\begin{array}{c}34.3 \\
(2.71) \\
\end{array}$ & $\begin{array}{c}4.18 \\
(0.004) \\
\end{array}$ & $\begin{array}{c}7.47 \\
(0.001) \\
\end{array}$ \\
\hline $\begin{array}{l}\text { Soil/bare } \\
\text { (\%) }\end{array}$ & $\begin{array}{c}0.1 \\
(0.023)\end{array}$ & $\begin{array}{c}0.5 \\
(0.304)\end{array}$ & $\begin{array}{c}0.0 \\
(0.000)\end{array}$ & $\begin{array}{c}0.2 \\
(0.134) \\
\end{array}$ & $\begin{array}{c}0.0 \\
(0.025)\end{array}$ & $\begin{array}{c}0.78 \\
(0.544)\end{array}$ & $\begin{array}{c}0.91 \\
(0.443)\end{array}$ \\
\hline $\begin{array}{l}\text { Grass/herb } \\
(\%)\end{array}$ & $\begin{array}{c}21.6 \\
(2.18) \\
\end{array}$ & $\begin{array}{c}26.0 \\
(1.62) \\
\end{array}$ & $\begin{array}{c}7.1 \\
(3.65) \\
\end{array}$ & $\begin{array}{c}30.4 \\
(3.03) \\
\end{array}$ & $\begin{array}{c}21.5 \\
(1.77) \\
\end{array}$ & $\begin{array}{c}5.96 \\
(0.001) \\
\end{array}$ & $\begin{array}{c}3.22 \\
(0.028) \\
\end{array}$ \\
\hline Water (\%) & $\begin{array}{c}6.8 \\
(14.05)\end{array}$ & $\begin{array}{c}3.5 \\
(10.12)\end{array}$ & $\begin{array}{c}4.3 \\
(8.50)\end{array}$ & $\begin{array}{c}1.4 \\
(5.37)\end{array}$ & $\begin{array}{l}1.49 \\
(4.7)\end{array}$ & $\begin{array}{c}0.85 \\
(0.496)\end{array}$ & $\begin{array}{c}1.12 \\
(0.349)\end{array}$ \\
\hline $\begin{array}{l}\text { Total } \\
\text { green (\%) }\end{array}$ & $\begin{array}{c}37.8 \\
(13.13) \\
\end{array}$ & $\begin{array}{c}47.4 \\
(9.66) \\
\end{array}$ & $\begin{array}{c}46.7 \\
(43.35) \\
\end{array}$ & $\begin{array}{c}58.1 \\
(15.41) \\
\end{array}$ & $\begin{array}{c}64.2 \\
(11.05) \\
\end{array}$ & $\begin{array}{c}6.51 \\
(0.0002) \\
\end{array}$ & $\begin{array}{c}12.68 \\
(<0.001) \\
\end{array}$ \\
\hline $\begin{array}{l}\text { Density } \\
\text { (\#/ha) }\end{array}$ & $\begin{array}{c}18.0 \\
(3.64)\end{array}$ & $\begin{array}{c}17.9 \\
(2.99)\end{array}$ & $\begin{array}{c}27.2 \\
(14.07)\end{array}$ & $\begin{array}{c}18.4 \\
(1.99)\end{array}$ & $\begin{array}{c}16.1 \\
(2.29)\end{array}$ & $\begin{array}{c}0.56 \\
(0.691)\end{array}$ & $\begin{array}{c}0.09 \\
(0.963)\end{array}$ \\
\hline PC1 & $\begin{array}{c}0.799 \\
(0.170)\end{array}$ & $\begin{array}{c}0.447 \\
(0.183) \\
\end{array}$ & $\begin{array}{c}0.039 \\
(1.791) \\
\end{array}$ & $\begin{array}{c}-0.404 \\
(0.278) \\
\end{array}$ & $\begin{array}{l}-1.159 \\
(0.243)\end{array}$ & $\begin{array}{c}5.83 \\
(0.001) \\
\end{array}$ & $\begin{array}{c}12.30 \\
(0.001)\end{array}$ \\
\hline PC2 & $\begin{array}{c}-0.271 \\
(0.418)\end{array}$ & $\begin{array}{c}-0.164 \\
(0.307)\end{array}$ & $\begin{array}{c}0.604 \\
(0.784)\end{array}$ & $\begin{array}{c}0.141 \\
(0.158)\end{array}$ & $\begin{array}{c}0.204 \\
(0.170)\end{array}$ & $\begin{array}{c}0.68 \\
(0.607) \\
\end{array}$ & $\begin{array}{c}0.58 \\
(0.631)\end{array}$ \\
\hline PC3 & $\begin{array}{l}-0.065 \\
(0.173) \\
\end{array}$ & $\begin{array}{c}0.244 \\
(0.169) \\
\end{array}$ & $\begin{array}{c}-1.720 \\
(0.517) \\
\end{array}$ & $\begin{array}{c}0.474 \\
(0.292) \\
\end{array}$ & $\begin{array}{l}-0.582 \\
(0.211) \\
\end{array}$ & $\begin{array}{c}6.07 \\
(0.000) \\
\end{array}$ & $\begin{array}{c}3.47 \\
(0.021)\end{array}$ \\
\hline
\end{tabular}


Table 1.2. Results of the principal components analysis of habitat cover and human population density in $150 \mathrm{~m}$ (above) and $500 \mathrm{~m}$ (below) diameter circles surrounding each of 73 randomly chosen avian survey points in Portland, Oregon. Cell entries are factor loadings for eigenvectors, along with eigenvalues and proportion of the variance explained by each eigenvector, and the cumulative total variation explained.

\begin{tabular}{|c|c|c|c|}
\hline & \multicolumn{3}{|c|}{ Eigenvectors (150) } \\
\hline Variables & PC1 & PC2 & PC3 \\
\hline Canopy cover & 0.539 & -0.470 & -0.266 \\
\hline Population density & 0.112 & -0.161 & 0.679 \\
\hline Impervious Surface & -0.703 & -0.087 & 0.149 \\
\hline Soil or Bare & 0.071 & 0.211 & 0.486 \\
\hline Grass/herbaceous & 0.444 & 0.469 & 0.294 \\
\hline Water & -0.020 & 0.694 & -0.350 \\
\hline Eigenvalue & 1.924 & 1.311 & 1.243 \\
\hline Variation (\%) & 32.1 & 21.8 & 20.7 \\
\hline \multirow[t]{3}{*}{ Cumulative variation (\%) } & 32.1 & 53.9 & 74.6 \\
\hline & \multicolumn{3}{|c|}{ Eigenvectors (500) } \\
\hline & PC1 & PC2 & PC3 \\
\hline Canopy cover & 0.619 & 0.232 & -0.418 \\
\hline Population density & -0.197 & 0.626 & 0.059 \\
\hline Impervious Surface & -0.695 & 0.164 & -0.113 \\
\hline Soil or Bare & -0.248 & -0.238 & -0.122 \\
\hline Grass/herbaceous & 0.179 & 0.026 & 0.890 \\
\hline Water & -0.043 & -0.686 & -0.039 \\
\hline Eigenvalue & 1.814 & 1.457 & 1.148 \\
\hline Variation (\%) & 30.2 & 24.3 & 19.1 \\
\hline Cumulative variation (\%) & 30.2 & 54.5 & 73.7 \\
\hline
\end{tabular}


Table 1.3. Comparison of the avian community characteristics, including total avian abundance (number of birds per survey), species richness (number of species), and species diversity (Shannon-Weiner Index), for the different regions of Portland, Oregon. Numbers in parentheses following region name are sample sizes for random points used to collect both bird and landscape/population data. Comparisons of means made using analysis of variance with $\left(F[P]^{1}\right)$ and without $\left(F[P]^{2}\right)$ the Northwest region included in the analysis.

\begin{tabular}{|l|c|c|c|c|c|c|c|}
\hline & NP (15) & NE (22) & NW (4) & SE (20) & SW (12) & $F(P)^{1}$ & $F(P)^{2}$ \\
\hline $\begin{array}{l}\text { Abundanc } \\
\text { e }\end{array}$ & 10.8 & 10.8 & 6.1 & 11.9 & 13.8 & 4.07 & 2.35 \\
\hline Richness & 3.8 & 3.7 & 2.8 & 3.8 & 3.9 & 0.80 & 0.07 \\
& $(0.33)$ & $(0.27)$ & $(0.76)$ & $(0.24)$ & $(0.20)$ & $(0.529)$ & $(0.974)$ \\
\hline Diversity & 2.14 & 2.02 & 1.96 & 2.28 & 2.40 & 2.74 & 3.63 \\
& $(0.078)$ & $(0.094)$ & $(0.363)$ & $(0.077)$ & $(0.046)$ & $(0.036)$ & $(0.017)$ \\
\hline
\end{tabular}


Table 1.4. Correlation coefficients $(r)$ and alpha ( $P$, in parentheses) describing the relationships between avian abundance, species richness, and species diversity in Portland, OR in relation to landscape variables, human population density, and composite measures of landscape composition derived from principal component analyses of landscape variables. Results are reported only if alpha of correlation coefficients were $\leq 0.10$.

\begin{tabular}{|c|c|c|c|}
\hline \multicolumn{4}{|c|}{ Average abundance; $r(P)$} \\
\hline \multicolumn{2}{|c|}{150 m circle } & \multicolumn{2}{|c|}{$500 \mathrm{~m}$ circle } \\
\hline Canopy cover & $0.274(0.019)$ & Canopy cover & $0.196(0.097)$ \\
\hline Grass/herbaceous & $0.205(0.082)$ & Impervious surface & $-0.205(0.082)$ \\
\hline Impervious surface & $-0.362(0.002)$ & Soil/bare ground & $0.206(0.080)$ \\
\hline Soil/bare ground & $-0.249(0.034)$ & Total green & $0.264(0.024)$ \\
\hline Total Green & $0.350(0.002)$ & & \\
\hline$P C 1_{150}$ & $0.340(0.003)$ & & \\
\hline $\mathrm{PC}_{150}$ & $-0.196(0.096)$ & & \\
\hline \multicolumn{4}{|c|}{ Species richness; $r(P)$} \\
\hline \multicolumn{2}{|c|}{150 m circle } & \multicolumn{2}{|c|}{$500 \mathrm{~m}$ circle } \\
\hline Grass/Herbaceous & $0.207(0.079)$ & Impervious surface & $-0.228(0.053)$ \\
\hline Impervious surface & $-0.290(0.013)$ & Population density & $-0.291(0.012)$ \\
\hline Population density & $-0.194(0.099)$ & Soil/bare ground & $0.198(0.093)$ \\
\hline Total green & $0.228(0.052)$ & $P C 2500$ & $-0.306(0.008)$ \\
\hline Water & $0.219(0.063)$ & & \\
\hline$P C 1_{150}$ & $0.231(0.049)$ & & \\
\hline $\mathrm{PC} 2_{150}$ & $0.216(0.067)$ & & \\
\hline $\mathrm{PC}_{150}$ & $-0.219(0.063)$ & & \\
\hline \multicolumn{4}{|c|}{ Species diversity; $r(P)$} \\
\hline \multicolumn{2}{|c|}{$150 \mathrm{~m}$ circle } & \multicolumn{2}{|c|}{500 m circle } \\
\hline Canopy cover & $0.398(0.005)$ & Canopy cover & $0.384(0.001)$ \\
\hline Impervious surface & $-0.497(<0.001)$ & Impervious surface & $\begin{array}{c}- \\
0.434(<0.001)\end{array}$ \\
\hline Soil/bare ground & $-0.310(0.008)$ & Total green & $\begin{array}{c}-0.414 \\
(<0.001)\end{array}$ \\
\hline Total green & $0.451(<0.001)$ & $\mathrm{PC}_{500}$ & $0.351(0.002)$ \\
\hline$P C 1_{150}$ & $0.440(<0.001)$ & & \\
\hline $\mathrm{PC}_{150}$ & $-0.335(0.004)$ & & \\
\hline
\end{tabular}




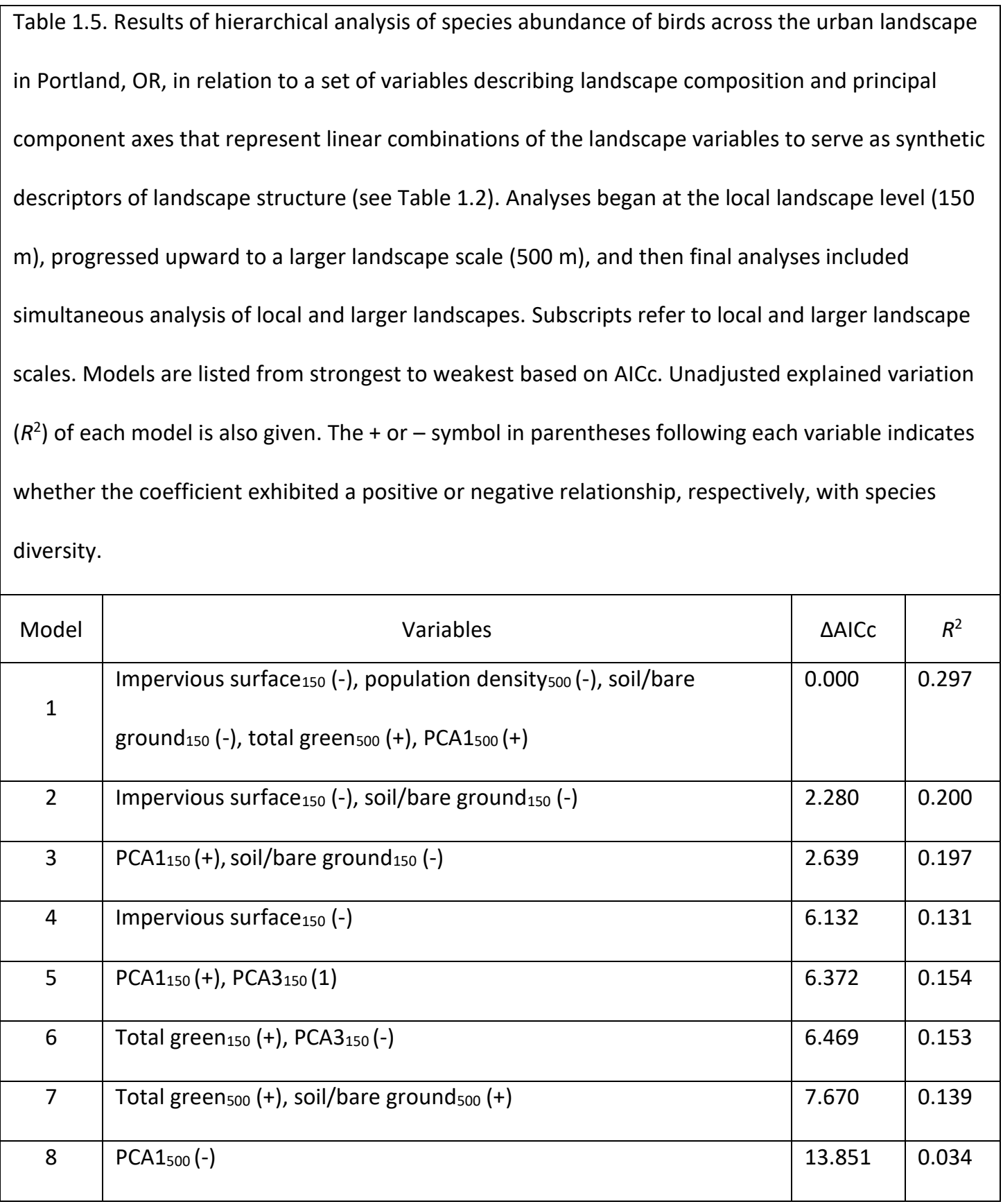




\begin{tabular}{|c|c|c|c|}
\hline Model & & & \\
\hline & & & \\
\hline 1 & $\begin{array}{l}\text { Grass/herb } 150(+) \text {, canopy cover } 500(+), \text { PCA1 }_{500}(+), \text { PCA2 } 500 \\
(-)\end{array}$ & 0.000 & 0.230 \\
\hline 2 & $\begin{array}{l}\text { Grass/herb }_{150}(+) \text {, canopy cover } \\
500(+) \text {, impervious } \\
\text { surface }_{500}(+), \text { PCA }_{500}(-)\end{array}$ & 0.220 & 0.228 \\
\hline 3 & PCA2 $_{500}(-)$, total green $150(+)$ & 3.450 & 0.139 \\
\hline 4 & Grass/herb $_{150}(+)$, PCA3 $_{150}(-)$ & 3.838 & 0.135 \\
\hline 5 & Canopy cover $_{150}(-)$, impervious surface $150(-)$, PCA3 $_{150}(-)$ & 3.998 & 0.160 \\
\hline 6 & PCA2 $500(-)$, canopy cover $500(+)$ & 4.349 & 0.129 \\
\hline 7 & $\begin{array}{l}\text { Impervious surface } 150(-) \text {, canopy } \text { cover }_{150}(-) \text {, population } \\
\text { density }_{150}(-)\end{array}$ & 4.432 & 0.155 \\
\hline 8 & Impervious surface $150(-)$, population density $150(-)$ & 4.588 & 0.126 \\
\hline 9 & PCA2 $500(-)$, impervious surface $500(-)$ & 4.811 & 0.123 \\
\hline 10 & $\begin{array}{l}\text { Impervious surface } 500(-) \text {, population density } 500(-) \text {, } \\
\text { soil/bare ground }_{500}(+)\end{array}$ & 4.912 & 0.149 \\
\hline 11 & PCA3 $_{500}(-)$ & 4.955 & 0.094 \\
\hline 12 & $\mathrm{PCA}_{150}(+), \mathrm{PCA}_{150}(+), \mathrm{PCA}_{150(-)}$ & 5.032 & 0.148 \\
\hline 13 & Impervious surface $150(-)$, PCA $_{150}(+)$ & 5.106 & 0.120 \\
\hline 14 & Population density $150(-)$, water $_{150}(+)$, total green $150(+)$ & 5.301 & 0.145 \\
\hline 15 & PCA3 $_{150}(-)$, impervious surface $150(-)$ & 5.547 & 0.114 \\
\hline 16 & Total green $_{150}(+)$, PCA $_{150}(+)$ & 5.612 & 0.113 \\
\hline 17 & Population density $500(-)$ & 5.682 & 0.085 \\
\hline 18 & PCA1 $_{150}(+)$, population density $150(-)$, Water $_{150}(+)$ & 5.714 & 0.140 \\
\hline 19 & Impervious surface $150(-)$ & 5.721 & 0.084 \\
\hline 20 & Population density $500(-)$, soil/bare ground $500(+)$ & 5.775 & 0.111 \\
\hline 21 & PCA1 $_{150}(+)$, population density $150(-)$ & 6.049 & 0.108 \\
\hline 22 & $\mathrm{PCA}_{150}(+), \mathrm{PCA}_{150}(-)$ & 6.597 & 0.101 \\
\hline 23 & $\mathrm{PCA}_{150}(+), \mathrm{PCA}_{150}(+)$ & 6.706 & 0.100 \\
\hline 24 & PCA1 $_{500}(+)$, soil/bare ground $150(+)$ & 6.874 & 0.098 \\
\hline
\end{tabular}


Table 1.7. Results of hierarchical analysis of species diversity of birds across the urban landscape in Portland, OR, in relation to a set of variables describing landscape composition and principal component axes that represent linear combinations of the landscape variables to serve as synthetic descriptors of landscape structure (see Table 1.2). Analyses began at the local landscape level $(150 \mathrm{~m})$, progressed upward to a larger landscape scale $(500 \mathrm{~m})$, and then final analyses included simultaneous analysis of local and larger landscapes. Subscripts refer to local and larger landscape scales. Models are listed from strongest to weakest based on AICc. Unadjusted explained variation $\left(R^{2}\right)$ of each model is also given. The + or - symbol in parentheses following each variable indicates whether the coefficient exhibited a positive or negative relationship, respectively, with species diversity.

\begin{tabular}{|c|c|c|c|}
\hline Model & Variables & $\triangle \mathrm{AICC}$ & $R^{2}$ \\
\hline 1 & $\begin{array}{l}\text { Impervious surface } 150(-) \text {, soil/bare } \operatorname{grd}_{150}(-), \text { PCA2 }_{500}(-) \text {, } \\
\text { PCA3 }_{500}(-)\end{array}$ & 0.000 & 0.416 \\
\hline 2 & $\begin{array}{l}\text { Impervious surface } 150(-) \text {, soil/bare } \operatorname{grd}_{150}(-), \text { PCA2 }_{500}(-) \text {, } \\
\text { Grass/herb }_{500}(-)\end{array}$ & 0.644 & 0.411 \\
\hline 3 & $\begin{array}{l}\text { Impervious surface } 150(-) \text {, soil/bare } \operatorname{grd}_{150}(-), \text { PCA2 }_{500}(-) \text {, } \\
\text { Canopy cover } \\
500(+)\end{array}$ & 1.830 & 0.401 \\
\hline 4 & Impervious surface $150(-)$, soil/bare $\operatorname{grd}_{150}(-)$ & 2.441 & 0.356 \\
\hline 5 & Soil/bare ground $150(-)$, Water $_{150}(+), \mathrm{PC}_{150}(+)$ & 5.340 & 0.351 \\
\hline 6 & Impervious surface $150(-)$, PCA3 $_{150}(-)$ & 7.229 & 0.312 \\
\hline 7 & $\mathrm{PCA}_{150}(+), \mathrm{PCA}_{150}(-)$ & 7.902 & 0.306 \\
\hline 8 & Impervious surface $500(-), P C 3_{500}(-)$ & 16.483 & 0.220 \\
\hline 9 & Grass/herb $_{500}(-)$, Impervious surface $_{500}(-)$ & 16.838 & 0.216 \\
\hline 10 & Impervious surface $500(-)$ & 17.142 & 0.188 \\
\hline 11 & Soil/bare ground ${ }_{500}(+), P 1_{500}(+)$ & 18.389 & 0.199 \\
\hline
\end{tabular}




\begin{tabular}{|c|c|c|c|c|}
\hline \multicolumn{5}{|c|}{$\begin{array}{l}\text { between each variable and species diversity of birds among survey points from the } \\
\text { urban landscape of Portland, OR. Confidence intervals (85\%; Arnold 2010), } \\
\text { importance weight of variables }\left(w_{i}\right) \text {, and likelihood of each variable in relation to the } \\
\text { top variable (L) are provided. }\end{array}$} \\
\hline Variables & $\mathrm{b}(\mathrm{SE})$ & $\mathrm{Cl}$ & $w_{i}$ & $\mathrm{~L}$ \\
\hline Impervious surface 150 & $-0.010(0.0022)$ & -0.014 to -0.007 & 1.000 & $\begin{array}{l}------ \\
--\end{array}$ \\
\hline Soil/bare 150 & $-0.546(0.1646)$ & -0.787 to -0.305 & 1.000 & 1.000 \\
\hline PC2 500 & $-0.059(0.0308)$ & -0.104 to -0.040 & 1.000 & 1.000 \\
\hline $\mathrm{PC}_{500}$ & $-0.031(0.0230)$ & -0.064 to 0.003 & 0.471 & 2.123 \\
\hline Grass/herbaceous500 & $-0.002(0.0018)$ & -0.005 to 0.001 & 0.341 & 2.933 \\
\hline Canopy cover 500 & $0.001(0.001)$ & -0.0004 to 0.0019 & 0.188 & 5.319 \\
\hline
\end{tabular}




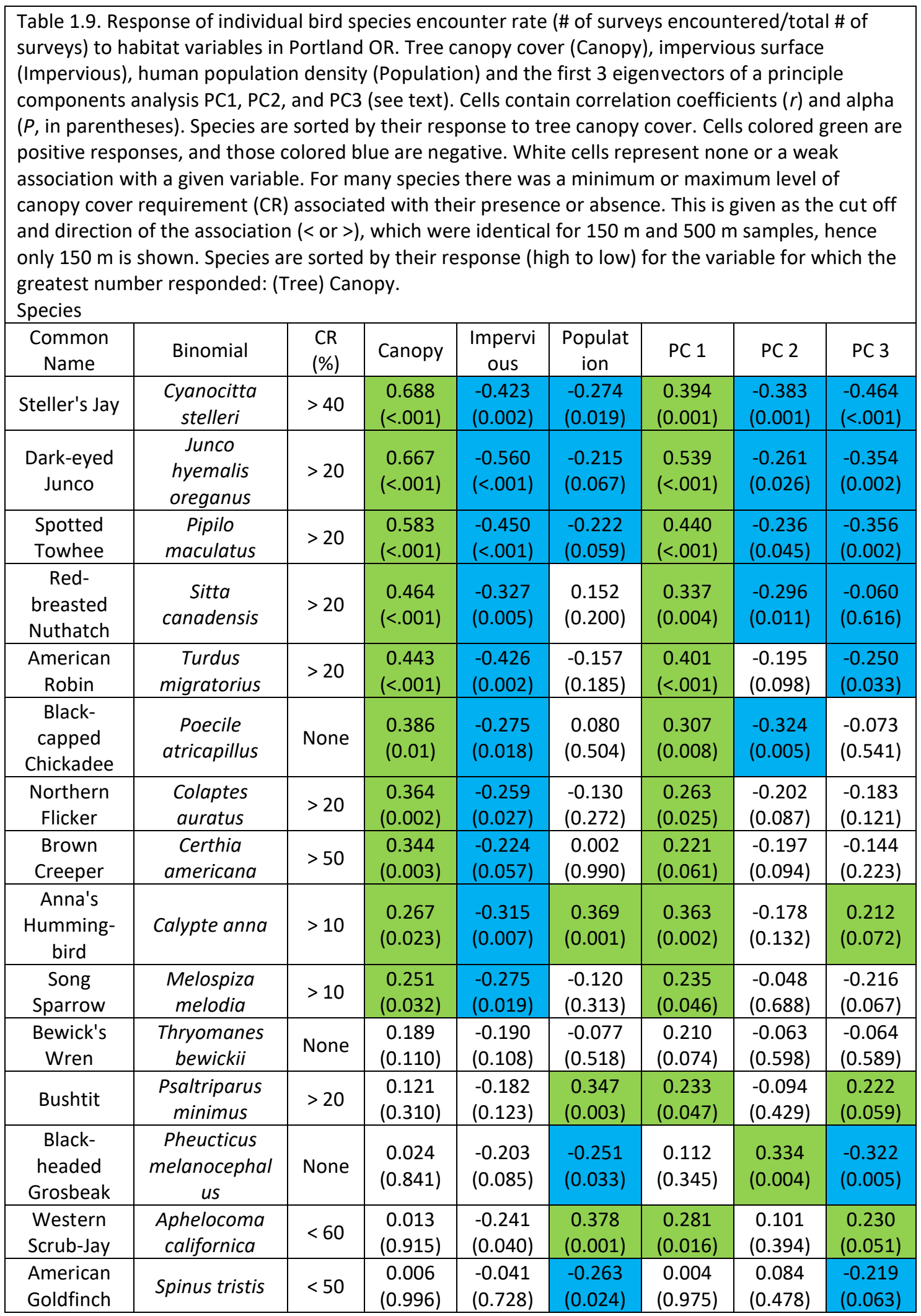




\begin{tabular}{|c|c|c|c|c|c|c|c|c|}
\hline $\begin{array}{c}\text { Lesser } \\
\text { Goldfinch }\end{array}$ & Spinus psaltria & None & $\begin{array}{c}-0.058 \\
(0.628)\end{array}$ & $\begin{array}{c}-0.061 \\
(0.608)\end{array}$ & $\begin{array}{c}0.041 \\
(0.731)\end{array}$ & $\begin{array}{c}0.090 \\
(0.449)\end{array}$ & $\begin{array}{c}0.063 \\
(0.594)\end{array}$ & $\begin{array}{c}0.118 \\
(0.320)\end{array}$ \\
\hline $\begin{array}{c}\text { House } \\
\text { Finch }\end{array}$ & $\begin{array}{c}\text { Haemorhous } \\
\text { mexicanus }\end{array}$ & $<20$ & $\begin{array}{c}-0.069 \\
(0.560)\end{array}$ & $\begin{array}{c}0.019 \\
(0.870)\end{array}$ & $\begin{array}{c}0.201 \\
(0.089)\end{array}$ & $\begin{array}{c}-0.026 \\
(0.830)\end{array}$ & $\begin{array}{c}0.056 \\
(0.641)\end{array}$ & $\begin{array}{c}0.058 \\
(0.625)\end{array}$ \\
\hline $\begin{array}{c}\text { Cedar } \\
\text { Waxwing }\end{array}$ & $\begin{array}{c}\text { Bombycilla } \\
\text { cedrorum }\end{array}$ & $<40$ & $\begin{array}{c}-0.073 \\
(0.537)\end{array}$ & $\begin{array}{c}-0.063 \\
(0.595)\end{array}$ & $\begin{array}{c}-0.041 \\
(0.731)\end{array}$ & $\begin{array}{c}0.069 \\
(0.560)\end{array}$ & $\begin{array}{c}0.107 \\
(0.369)\end{array}$ & $\begin{array}{c}0.067 \\
(0.573)\end{array}$ \\
\hline $\begin{array}{c}\text { Rock } \\
\text { Pigeon }\end{array}$ & Columba livia & $<40$ & $\begin{array}{c}-0.110 \\
(0.355)\end{array}$ & $\begin{array}{c}0.074 \\
(0.536)\end{array}$ & $\begin{array}{c}0.074 \\
(0.534)\end{array}$ & $\begin{array}{c}-0.066 \\
(0.577)\end{array}$ & $\begin{array}{c}-0.001 \\
(0.992)\end{array}$ & $\begin{array}{c}0.085 \\
(0.476)\end{array}$ \\
\hline $\begin{array}{c}\text { American } \\
\text { Crow }\end{array}$ & $\begin{array}{c}\text { Corvus } \\
\text { brachyrhyn- } \\
\text { chos }\end{array}$ & None & $\begin{array}{c}-0.142 \\
(0.231)\end{array}$ & $\begin{array}{c}0.112 \\
(0.347)\end{array}$ & $\begin{array}{c}0.194 \\
(0.101)\end{array}$ & $\begin{array}{c}-0.123 \\
(0.302)\end{array}$ & $\begin{array}{c}-0.014 \\
(0.908)\end{array}$ & $\begin{array}{c}0.100 \\
(0.401)\end{array}$ \\
\hline $\begin{array}{c}\text { Mourning } \\
\text { Dove }\end{array}$ & $\begin{array}{c}\text { Zenaida } \\
\text { macroura }\end{array}$ & $<40$ & $\begin{array}{c}-0.163 \\
(0.169)\end{array}$ & $\begin{array}{c}0.069 \\
(0.564)\end{array}$ & $\begin{array}{c}-0.206 \\
(0.081)\end{array}$ & $\begin{array}{c}-0.078 \\
(0.514)\end{array}$ & $\begin{array}{c}0.191 \\
(0.105)\end{array}$ & $\begin{array}{c}-0.098 \\
(0.412)\end{array}$ \\
\hline $\begin{array}{c}\text { White- } \\
\text { crowned } \\
\text { Sparrow }\end{array}$ & $\begin{array}{c}\text { Zonotrichia } \\
\text { leucophrys }\end{array}$ & $<30$ & $\begin{array}{c}-0.247 \\
(0.035)\end{array}$ & $\begin{array}{c}0.186 \\
(0.115)\end{array}$ & $\begin{array}{c}-0.341 \\
(0.003)\end{array}$ & $\begin{array}{c}-0.253 \\
(0.031)\end{array}$ & $\begin{array}{c}0.172 \\
(0.145)\end{array}$ & $\begin{array}{c}-0.197 \\
(0.096)\end{array}$ \\
\hline $\begin{array}{c}\text { House } \\
\text { Sparrow }\end{array}$ & $\begin{array}{c}\text { Passer } \\
\text { domesticus }\end{array}$ & $<50$ & $\begin{array}{c}-0.306 \\
(0.009)\end{array}$ & $\begin{array}{c}0.166 \\
(0.160)\end{array}$ & $\begin{array}{c}0.268 \\
(0.022)\end{array}$ & $\begin{array}{c}-0.146 \\
(0.218)\end{array}$ & $\begin{array}{c}0.119 \\
(0.317)\end{array}$ & $\begin{array}{c}0.241 \\
(0.040)\end{array}$ \\
\hline $\begin{array}{c}\text { European } \\
\text { Starling }\end{array}$ & $\begin{array}{c}\text { Sturnus } \\
\text { vulgaris }\end{array}$ & $<60$ & $\begin{array}{c}0.318 \\
(0.006)\end{array}$ & $\begin{array}{c}0.177 \\
(0.134)\end{array}$ & $\begin{array}{c}0.018 \\
(0.882)\end{array}$ & $\begin{array}{c}-0.189 \\
(0.109)\end{array}$ & $\begin{array}{c}0.269 \\
(0.021)\end{array}$ & $\begin{array}{c}0.009 \\
(0.943)\end{array}$ \\
\hline
\end{tabular}




\begin{tabular}{|c|c|c|c|c|c|c|}
\hline Common Name & Habitat & Food & Nesting & Foraging & Winter & Mass \\
\hline Steller's Jay & Forest & Omnivore & Tree & Ground & Res & 120 \\
\hline Dark-eyed Junco & Forest & Seeds & Ground & Ground & Res & 24 \\
\hline Spotted Towhee & Scrub & Omnivore & Ground & Ground & Res & 41 \\
\hline $\begin{array}{l}\text { Chestnut-backed } \\
\text { Chickadee }\end{array}$ & Forest & Insects & Cavity & Foliage & Res & 9.5 \\
\hline Red-breasted Nuthatch & Forest & Insects & Cavity & Bark & Res & 10.5 \\
\hline American Robin & Open Wood & Insects & Tree & Ground & Res & 81 \\
\hline Black-capped Chickadee & Forest & Insects & Cavity & Foliage & Res & 11.5 \\
\hline Northern Flicker & Open Wood & Insects & Cavity & Ground & Res & 135 \\
\hline Brown Creeper & Forest & Insects & Tree & Bark & Res & 7.5 \\
\hline Anna's Hummingbird & Open Wood & Nectar & Tree & Hovering & Res & 4.5 \\
\hline Song Sparrow & Open Wood & Insects & Shrub & Ground & Res & 32.5 \\
\hline Bewick's Wren & Open Wood & Insects & Cavity & Foliage & Res & 10 \\
\hline Bushtit & Scrub & Insects & Tree & Foliage & Res & 5 \\
\hline Black-headed Grosbeak & Forest & Insects & Tree & Foliage & Mig & 42 \\
\hline Western Scrub-Jay & Scrub & Omnivore & Tree & Ground & Res & 85 \\
\hline American Goldfinch & Open Wood & Seeds & Shrub & Foliage & Res & 15.5 \\
\hline Lesser Goldfinch & Open Wood & Seeds & Tree & Foliage & Res & 15 \\
\hline House Finch & Town & Seeds & Tree/Build & Ground & Res & 21.5 \\
\hline Cedar Waxwing & Open Wood & Fruit & Tree & Foliage & Res & 32 \\
\hline Rock Pigeon & Town & Seeds & Building & Ground & Res & 322.5 \\
\hline American Crow & Open Wood & Omnivore & Tree & Ground & Res & 468 \\
\hline Mourning Dove & Open Wood & Seeds & Tree & Ground & Res & 121 \\
\hline White-crowned Sparrow & Scrub & Insects & Ground & Ground & Mig & 26.5 \\
\hline House Sparrow & Town & Seeds & Cavit/Build & Ground & Inv & 28 \\
\hline European Starling & Town & Insects & Cavity & Ground & Inv & 78 \\
\hline
\end{tabular}




\section{Chapter References 1}

Andersson, Erik, Stephan Barthel, Sara Borgström, Johan Colding, Thomas Elmqvist, Carl Folke, and Åsa Gren. 2014. "Reconnecting Cities to the Biosphere: Stewardship of Green Infrastructure and Urban Ecosystem Services." Ambio 43 (4):445-53. http://dx.doi.org.libproxy.pcc.edu/10.1007/s13280-014-0506-y.

Arnold, Todd W. 2010. "Uninformative Parameters and Model Selection Using Akaike's Information Criterion." The Journal of Wildlife Management 74 (6):1175-78. https://doi.org/10.1111/i.1937-2817.2010.tb01236.x.

Babey, Susan H., Theresa A. Hastert, and E. Richard Brown. 2007. "Teens Living in Disadvantaged Neighborhoods Lack Access to Parks and Get Less Physical Activity." UCLA Center for Health Policy Research, March. http://escholarship.org/uc/item/4ww2p7v4.

Bartos-Smith, S., J. E. McKay, J. K. Richardson, A. A. Shipley, and M. T. Murphy. 2016. Demography of a ground nesting bird in an urban system: Are populations selfsustaining? Urban Ecosystems 19:577-598. DOI 10.1007/s11252-016-0532-6

Becker, Miles E., Peter A. Bednekoff, Michael W. Janis, and Donald C. Ruthven. 2009. "Characteristics of Foraging Perch-Sites Used by Loggerhead Shrikes." The Wilson Journal of Ornithology 121 (1):104-11.

Belaire, J. Amy, Christopher J. Whelan, and Emily S. Minor. 2014. "Having Our Yards and Sharing Them Too: The Collective Effects of Yards on Native Bird Species in an Urban Landscape." Ecological Applications 24 (8):2132-43. https://doi.org/10.1890/13-2259.1.

Benito, Gerardo, and Jim E. O’Connor. 2003. “Number and Size of Last-Glacial Missoula Floods in the Columbia River Valley between the Pasco Basin, Washington, and Portland, Oregon." GSA Bulletin 115 (5):624-38. https://doi.org/10.1130/00167606(2003)115<0624:NASOLM>2.0.CO;2.

Berman, Marc G., John Jonides, and Stephen Kaplan. 2008. "The Cognitive Benefits of Interacting With Nature." Psychological Science 19 (12):1207-12. https://doi.org/10.1111/i.1467-9280.2008.02225.x.

Breyer, Betsy, and Adriana Voss-Andreae. 2013. "Food Mirages: Geographic and Economic Barriers to Healthful Food Access in Portland, Oregon." Health and Place 24 (November):131-39. https://doi.org/10.1016/i.healthplace.2013.07.008. 
Brown, Jeffrey S., Martha Sutula, Chris Stransky, John Rudolph, and Earl Byron. 2010.

"Sediment Contaminant Chemistry and Toxicity of Freshwater Urban Wetlands in Southern California1." JAWRA Journal of the American Water Resources Association 46 (2):367-85. https://doi.org/10.1111/j.1752-1688.2009.00407.x.

Carbó-Ramírez, Pilar, and Iriana Zuria. 2011. "The Value of Small Urban Greenspaces for Birds in a Mexican City." Landscape and Urban Planning 100 (3):213-22. https://doi.org/10.1016/j.landurbplan.2010.12.008.

Carrascal, Luis M., Ismael Galván, and Oscar Gordo. 2009. “Partial Least Squares Regression as an Alternative to Current Regression Methods Used in Ecology." Oikos 118 (5):681-90. https://doi.org/10.1111/j.1600-0706.2008.16881.x.

Chace, Jameson F., and John J. Walsh. 2006. "Urban Effects on Native Avifauna: A Review." Landscape and Urban Planning 74 (1):46-69. https://doi.org/10.1016/j.landurbplan.2004.08.007.

Clergeau, Philippe, Jean-Pierre L. Savard, Gwenalle Mennechez, and Gilles Falardeau. 1998. "Bird Abundance and Diversity along an Urban-Rural Gradient: A Comparative Study between Two Cities on Different Continents." The Condor 100 (3):413-25. https://doi.org/10.2307/1369707.

Conway, Tenley M., Tooba Shakeel, and Joanna Atallah. 2011. "Community Groups and Urban Forestry Activity: Drivers of Uneven Canopy Cover?" Landscape and Urban Planning 101 (4):321-29. https://doi.org/10.1016/i.landurbplan.2011.02.037.

Crampton, Lisa H., and James S. Sedinger. 2011. "Nest-Habitat Selection by the Phainopepla: Congruence Across Spatial Scales But Not Habitat Types." The Condor 113 (1):209-22. http://dx.doi.org.libproxy.pcc.edu/10.1525/cond.2011.090206.

Crooks, Kevin R., and Michael E. Soule. 1999. "Mesopredator Release and Avifaunal Extinctions in a Fragmented System." Nature; London 400 (6744): 563-66. http://dx.doi.org.proxy.lib.pdx.edu/10.1038/23028.

Davis, Amélie Y., J. Amy Belaire, Monica A. Farfan, Dan Milz, Eric R. Sweeney, Scott R. Loss, and Emily S. Minor. 2012. "Green Infrastructure and Bird Diversity across an Urban Socioeconomic Gradient." Ecosphere 3 (11):1-18. https://doi.org/10.1890/ES12-00126.1.

Denman, L, P B May, and P F Breen. 2006. “An Investigation of the Potential to Use Street Trees and Their Root Zone Soils to Remove Nitrogen from Urban Stormwater." Australian Journal of Water Resources 10 (3):303-11. https://doi.org/10.1080/13241583.2006.11465306. 
Eggers, Sönke, Michael Griesser, and Jan Ekman. 2008. "Predator-Induced Reductions in Nest Visitation Rates Are Modified by Forest Cover and Food Availability." Behavioral Ecology 19 (5):1056-62. https://doi.org/10.1093/beheco/arn063.

Evans, Karl L., Dan E. Chamberlain, Ben J. Hatchwell, Richard D. Gregory, and Kevin J. Gaston. 2011. "What Makes an Urban Bird?" Global Change Biology 17 (1):32-44. https://doi.org/10.1111/j.1365-2486.2010.02247.x.

Evans, Karl L., Stuart E. Newson, and Kevin J. Gaston. 2009. "Habitat Influences on Urban Avian Assemblages." Ibis 151 (1):19-39. https://doi.org/10.1111/i.1474919X.2008.00898.x.

Fernández-Juricic, Esteban. 2000. "Bird Community Composition Patterns in Urban Parks of Madrid: The Role of Age, Size and Isolation." Ecological Research 15 (4):373-83. https://doi.org/10.1046/i.1440-1703.2000.00358.x.

Fischer, Jason D., Sarah H. Cleeton, Timothy P. Lyons, and James R. Miller. 2012. "Urbanization and the Predation Paradox: The Role of Trophic Dynamics in Structuring Vertebrate Communities." BioScience 62 (9):809-18. https://doi.org/10.1525/bio.2012.62.9.6.

Flory, S. Luke, and Keith Clay. 2010. "Non-Native Grass Invasion Suppresses Forest Succession." Oecologia 164 (4):1029-38. https://doi.org/10.1007/s00442-0101697-y.

Fuller, Richard A., Katherine N. Irvine, Patrick Devine-Wright, Philip H. Warren, and Kevin J. Gaston. 2007. "Psychological Benefits of Greenspace Increase with Biodiversity." Biology Letters 3 (4):390-94. https://doi.org/10.1098/rsbl.2007.0149.

Galván, Ismael, Alba Naudí, Johannes Erritzøe, Anders P. Møller, Gustavo Barja, and Reinald Pamplona. 2015. "Long Lifespans Have Evolved with Long and Monounsaturated Fatty Acids in Birds." Evolution 69 (10):2776-84. https://doi.org/10.1111/evo.12754.

Gibbs, Andrew Chapter 2 2018. "The efficacy of Portland Audubon's Backyard Certification Program at creating natural habitat."

Gibbs, Andrew Chapter 3 2018. "The Ability of the Backyard Habitat Certification Program, Certified Habitat Yards, to Support the Avian Community of Portland Oregon." 
Gibson, Karen J. 2007. "Bleeding Albina: A History of Community Disinvestment, 19402000." Transforming Anthropology 15 (1):3-25. https://doi.org/10.1525/tran.2007.15.1.03.

Goddard, Mark A., Andrew J. Dougill, and Tim G. Benton. 2010. "Scaling up from Gardens: Biodiversity Conservation in Urban Environments." Trends in Ecology and Evolution 25 (2):90-98. https://doi.org/10.1016/j.tree.2009.07.016.

Haddad, Nick M., Gregory M. Crutsinger, Kevin Gross, John Haarstad, Johannes M.H. Knops, and David Tilman. 2009. "Plant Species Loss Decreases Arthropod Diversity and Shifts Trophic Structure." Ecology Letters 12 (10):1029-39. https://doi.org/10.1111/i.1461-0248.2009.01356.x.

Hedblom Marcus, and Söderström Bo. 2010. "Landscape Effects on Birds in Urban Woodlands: An Analysis of 34 Swedish Cities." Journal of Biogeography 37 (7): 1302-16. https://doi.org/10.1111/i.1365-2699.2010.02299.x.

Heezik, Yolanda van, Amber Smyth, Amy Adams, and Joanna Gordon. 2010a. "Do Domestic Cats Impose an Unsustainable Harvest on Urban Bird Populations?" Biological Conservation 143 (1):121-30. https://doi.org/10.1016/i.biocon.2009.09.013.

Hennings, Lori A., and W. Daniel Edge. 2003. "Riparian Bird Community Structure in Portland, Oregon: Habitat, Urbanization, and Spatial Scale Patterns." The Condor 105 (2):288-302. https://doi.org/10.1650/00105422(2003)105[0288:RBCSIP]2.0.CO;2.

Hope, Diane, Corinna Gries, Weixing Zhu, William F. Fagan, Charles L. Redman, Nancy B. Grimm, Amy L. Nelson, Chris Martin, and Ann Kinzig. 2003. "Socioeconomics Drive Urban Plant Diversity." Proceedings of the National Academy of Sciences 100 (15):8788-92. https://doi.org/10.1073/pnas.1537557100.

Hostetler, Mark. 1999. "Scale, Birds, and Human Decisions: A Potential for Integrative Research in Urban Ecosystems." Landscape and Urban Planning 45 (1):15-19. https://doi.org/10.1016/S0169-2046(99)00025-0.

Houston, Douglas, Jun Wu, Paul Ong, and Arthur Winer. 2004. "Structural Disparities of Urban Traffic in Southern California: Implications for Vehicle-Related Air Pollution Exposure in Minority and High-Poverty Neighborhoods." Journal of Urban Affairs 26 (5):565-92. https://doi.org/10.1111/j.0735-2166.2004.00215.x. 
Hülsmann, Marietta, Henrik von Wehrden, Alexandra-Maria Klein, and Sara Diana Leonhardt. 2015. "Plant Diversity and Composition Compensate for Negative Effects of Urbanization on Foraging Bumble Bees." Apidologie 46 (6):760-70. https://doi.org/10.1007/s13592-015-0366-x.

Jackson, Laura E. 2003. "The Relationship of Urban Design to Human Health and Condition." Landscape and Urban Planning 64 (4):191-200. https://doi.org/10.1016/S0169-2046(02)00230-X.

Janhäll, Sara. 2015. "Review on Urban Vegetation and Particle Air Pollution - Deposition and Dispersion." Atmospheric Environment 105 (March):130-37. https://doi.org/10.1016/j.atmosenv.2015.01.052.

Jones, Elizabeth L., and Simon R. Leather. 2012. "Invertebrates in Urban Areas: A Review." European Journal of Entomology 109 (4):463-78.

Kalnay, Eugenia, and Ming Cai. 2003. "Impact of Urbanization and Land-Use Change on Climate." Nature 423 (6939):528-31. https://doi.org/10.1038/nature01675.

Kinzig, Ann P., Paige Warren, Chris Martin, Diane Hope, and Madhusudan Katti. 2005. "The Effects of Human Socioeconomic Status and Cultural Characteristics on Urban Patterns of Biodiversity." Ecology and Society 10 (1). http://www.jstor.org.proxy.lib.pdx.edu/stable/26267712.

Keresztesová, Sona, Ján Klein, and Zdenka Rózová. 2014. “Evaluation of Microclimatic Data on Localities with Different Ratio of Vegetation in Urban Environment." Ekológia 33 (4):301-6.

Klomp, Jennifer E., Michael T. Murphy, Sarah Bartos Smith, Jenny E. McKay, Isabella Ferrera, and Anna-Louise Reysenbach. 2008. "Cloacal Microbial Communities of Female Spotted Towhees Pipilo Maculatus: Microgeographic Variation and Individual Sources of Variability." Journal of Avian Biology 39 (5):530-38. https://doi.org/10.1111/i.0908-8857.2008.04333.x.

Koh, Chao-Nien, Pei-Fen Lee, and Ruey-Shing Lin. 2006. “Bird Species Richness Patterns of Northern Taiwan: Primary Productivity, Human Population Density, and Habitat Heterogeneity." Diversity and Distributions 12 (5):546-54. https://doi.org/10.1111/j.1366-9516.2006.00238.x.

Landry, Shawn M., and Jayajit Chakraborty. 2009. "Street Trees and Equity: Evaluating the Spatial Distribution of an Urban Amenity." Environment and Planning A 41 (11):2651-70. https://doi.org/10.1068/a41236. 
Lerman, Susannah B., Paige S. Warren, Hilary Gan, and Eyal Shochat. 2012. "Linking Foraging Decisions to Residential Yard Bird Composition." PLOS ONE 7 (8):e43497. https://doi.org/10.1371/journal.pone.0043497.

Longcore, Travis. 2003. "Terrestrial Arthropods as Indicators of Ecological Restoration Success in Coastal Sage Scrub (California, U.S.A.)." Restoration Ecology 11 (4):397409. https://doi.org/10.1046/i.1526-100X.2003.rec0221.x.

Loss, Scott R., Marilyn O. Ruiz, and Jeffrey D. Brawn. 2009. “Relationships between Avian Diversity, Neighborhood Age, Income, and Environmental Characteristics of an Urban Landscape." Biological Conservation 142 (11):2578-85. https://doi.org/10.1016/i.biocon.2009.06.004.

Loss, Scott R., Tom Will, and Peter P. Marra. 2013. "The Impact of Free-Ranging Domestic Cats on Wildlife of the United States." Nature Communications 4 (January):ncomms2380. https://doi.org/10.1038/ncomms2380.

Luck, Gary W. 2007. "A Review of the Relationships between Human Population Density and Biodiversity." Biological Reviews 82 (4):607-45. https://doi.org/10.1111/i.1469-185X.2007.00028.x.

Luvall, Jeffrey C., Dale A. Quattrochi, Doug Rickman, and Maury Estes. 2000. "Urban Forests Cool Hot Sites." Journal of Forestry 98 (3):F1.

Mainwaring, Mark C. 2015. "The Use of Man-Made Structures as Nesting Sites by Birds: A Review of the Costs and Benefits." Journal for Nature Conservation 25 (May):1722. https://doi.org/10.1016/i.jnc.2015.02.007.

Martin, Chris A., Paige S. Warren, and Ann P. Kinzig. 2004. "Neighborhood Socioeconomic Status Is a Useful Predictor of Perennial Landscape Vegetation in Residential Neighborhoods and Embedded Small Parks of Phoenix, AZ." Landscape and Urban Planning 69 (4):355-68. https://doi.org/10.1016/i.landurbplan.2003.10.034.

Marzluff, John M. 2001. "Worldwide Urbanization and Its Effects on Birds." In Avian Ecology and Conservation in an Urbanizing World, edited by John M. Marzluff, Reed Bowman, and Roarke Donnelly, 19-47. Springer US. https://doi.org/10.1007/978-1-4615-1531-9 2.

Marzluff, John M., Barbara Clucas, M. David Oleyar, and Jack DeLap. 2016. "The Causal Response of Avian Communities to Suburban Development: A Quasi-Experimental, Longitudinal Study." Urban Ecosystems 19 (4):1597-1621. https://doi.org/10.1007/s11252-015-0483-3. 
Mason, Jamie, Christopher Moorman, George Hess, and Kristen Sinclair. 2007.

"Designing Suburban Greenways to Provide Habitat for Forest-Breeding Birds." Landscape and Urban Planning 80 (1):153-64.

https://doi.org/10.1016/i.landurbplan.2006.07.002.

McDermott, Molly E., and Petra Bohall Wood. 2010. "Influence of Cover and Food Resource Variation on Post-Breeding Bird Use of Timber Harvests with Residual Canopy Trees." The Wilson Journal of Ornithology 122 (3):545-55.

McKinney, Michael L. 2008. "Effects of Urbanization on Species Richness: A Review of Plants and Animals." Urban Ecosystems 11 (2):161-76. https://doi.org/10.1007/s11252-007-0045-4.

McPherson, E. Gregory. 1988. "Functions of Buffer Plantings in Urban Environments." Agriculture, Ecosystems and Environment, Proceedings of an International Symposium on Windbreak Technology, 22 (August):281-98. https://doi.org/10.1016/0167-8809(88)90026-6.

Melles, Stephanie, Susan Glenn, and Kathy Martin. 2003. “Urban Bird Diversity and Landscape Complexity: Species-environment Associations Along a Multiscale Habitat Gradient." Conservation Ecology 7 (1). https://doi.org/10.5751/ES-00478$\underline{070105 .}$

Menke, S. B., R. N. Fisher, W. Jetz, and D. A. Holway. 2007. "Biotic and Abiotic Controls of Argentine Ant Invasion Success at Local and Landscape Scales." Ecology 88 (12):3164-73. https://doi.org/10.1890/07-0122.1.

Minor, Emily S., and Dean L. Urban. 2008. "A Graph-Theory Framework for Evaluating Landscape Connectivity and Conservation Planning." Conservation Biology 22 (2):297-307. https://doi.org/10.1111/j.1523-1739.2007.00871.x.

Minor, Emily, and Dean Urban. 2009. "Forest Bird Communities across a Gradient of Urban Development." Urban Ecosystems 13 (1):51-71. https://doi.org/10.1007/s11252-009-0103-1.

Oh, Kyushik, and Seunghyun Jeong. 2007. "Assessing the Spatial Distribution of Urban Parks Using GIS." Landscape and Urban Planning 82 (1):25-32. https://doi.org/10.1016/j.landurbplan.2007.01.014.

Ortega-Álvarez, Rubén, and Ian MacGregor-Fors. 2009. "Living in the Big City: Effects of Urban Land-Use on Bird Community Structure, Diversity, and Composition." Landscape and Urban Planning 90 (3): 189-95. https://doi.org/10.1016/j.landurbplan.2008.11.003. 
Oyugi, Joseph O., and Joel S. Brown. 2003. "Giving-up Densities and Habitat Preferences of European Starlings and American Robins." The Condor 105 (1):130-35.

Paker, Yair, Yoram Yom-Tov, Tal Alon-Mozes, and Anat Barnea. 2014. "The Effect of Plant Richness and Urban Garden Structure on Bird Species Richness, Diversity and Community Structure." Landscape and Urban Planning 122 (February):186-95. https://doi.org/10.1016/i.landurbplan.2013.10.005.

Palomino, David, and Luis M. Carrascal. 2006. "Urban Influence on Birds at a Regional Scale: A Case Study with the Avifauna of Northern Madrid Province." Landscape and Urban Planning 77 (3):276-90. https://doi.org/10.1016/j.landurbplan.2005.04.003.

Partecke, Jesko, Ingrid Schwabl, and Eberhard Gwinner. 2006. "Stress and the City: Urbanization and Its Effects on the Stress Physiology in European Blackbirds." Ecology 87 (8):1945-52. https://doi.org/10.1890/00129658(2006)87[1945:SATCUA]2.0.CO;2.

Payton, Seth, Greg Lindsey, Jeff Wilson, John R. Ottensmann, and Joyce Man. 2008. "Valuing the Benefits of the Urban Forest: A Spatial Hedonic Approach." Journal of Environmental Planning and Management 51 (6):717-36. https://doi.org/10.1080/09640560802423509.

Portland Oregon. 2007. "Urban Forest Management Plan". The City of Portland, Oregon. Accessed November 16, 2017a. https://www.portlandoregon.gov/parks/60402.

Portland City Council. 2012. "The Portland Plan - Final". The City of Portland, Oregon. http://www.portlandonline.com/portlandplan/index.cfm?c=56527.

Portland Metro Regional Government. 2014. "Fish and Wildlife Habitat Protection Plan". http://www.oregonmetro.gov/fish-and-wildlife-habitat-protection-plan.

Portland Oregon 2016 1. "Neighborhood Greenways." The City of Portland, Oregon. https://www.portlandoregon.gov/transportation/50518.

Portland Oregon 2016 2. "Residential Infill Project". The City of Portland, Oregon. http://www.portlandoregon.gov/bps/67728.

Reynolds, R. T., J. M. Scott, and R. A. Nussbaum. 1980. "A Variable Circular-Plot Method for Estimating Bird Numbers." The Condor 82 (3):309-13. https://doi.org/10.2307/1367399. 
Robb, Gillian N, Robbie A McDonald, Dan E Chamberlain, and Stuart Bearhop. 2008. "Food for Thought: Supplementary Feeding as a Driver of Ecological Change in Avian Populations." Frontiers in Ecology and the Environment 6 (9):476-84. https://doi.org/10.1890/060152.

Rodewald, P. (Editor). 2015. The Birds of North America: https://birdsna.org. Cornell Laboratory of Ornithology, Ithaca, NY.

Sandström, U. G., P. Angelstam, and G. Mikusiński. 2006. “Ecological Diversity of Birds in Relation to the Structure of Urban Green Space." Landscape and Urban Planning 77 (1):39-53. https://doi.org/10.1016/i.landurbplan.2005.01.004.

Säumel, Ina, Frauke Weber, and Ingo Kowarik. 2016. "Toward Livable and Healthy Urban Streets: Roadside Vegetation Provides Ecosystem Services Where People Live and Move." Environmental Science and Policy, Advancing urban environmental governance: Understanding theories, practices and processes shaping urban sustainability and resilience, 62 (August):24-33. https://doi.org/10.1016/i.envsci.2015.11.012.

Schlesinger, Matthew D., Patricia N. Manley, and Marcel Holyoak. 2008. "Distinguishing Stressors Acting on Land Bird Communities in an Urbanizing Environment." Ecology 89 (8):2302-14. https://doi.org/10.1890/07-0256.1.

Semenza, Jan C. 2003. "The Intersection of Urban Planning, Art, and Public Health: The Sunnyside Piazza." American Journal of Public Health 93 (9):1439-41.

Shipley, Amy A., Michael T. Murphy, and Adam H. Elzinga. 2013. "Residential Edges as Ecological Traps: Postfledging Survival of a Ground-Nesting Passerine in a Forested Urban Park." The Auk 130 (3):501-11. https://doi.org/10.1525/auk.2013.12139.

Tarvin, Keith A., and Mary C. Garvin. 2002. "Habitat and Nesting Success of Blue Jays (Cyanocitta Cristata): Importance of Scale." The Auk 119 (4):971-83.

Tomasevic, Jorge A., and John M. Marzluff. 2017. "Cavity Nesting Birds along an UrbanWildland Gradient: Is Human Facilitation Structuring the Bird Community?" Urban Ecosystems 20 (2):435-48. https://doi.org/10.1007/s11252-016-0605-6.

Tremblay Marie A., and St. Clair Colleen C. 2011. "Permeability of a Heterogeneous Urban Landscape to the Movements of Forest Songbirds." Journal of Applied Ecology 48 (3): 679-88. https://doi.org/10.1111/j.1365-2664.2011.01978.x.

Trimble, Donald E. 1963. Geology of Portland, Oregon, and Adjacent Areas. U.S. Government Printing Office. 
Trollope, Samuel T., John G. White, and Raylene Cooke. 2009. "The Response of Ground and Bark Foraging Insectivorous Birds across an Urban-forest Gradient." Landscape and Urban Planning 93 (2):142-50. https://doi.org/10.1016/i.landurbplan.2009.06.013.

U.S. Climate. 2017. "Climate Portland - Oregon and Weather Averages Portland." http://www.usclimatedata.com/climate/portland/oregon/united-states/usor0275.

United States Census Bureau. 2010. https://datamapper.geo.census.gov/map.html.

U.S. Census Bureau. 2017. QuickFacts Selected: Portland City, Oregon. Accessed August 28, 2017. https://www.census.gov/quickfacts/fact/table/portlandcityoregon/PST045216.

Wethington, Susan M., and Stephen M. Russell. 2003. "The Seasonal Distribution and Abundance of Hummingbirds in Oak Woodland and Riparian Communities in Southeastern Arizona." The Condor 105 (3):484-95. https://doi.org/10.1650/6931.

White, John G., Mark J. Antos, James A. Fitzsimons, and Grant C. Palmer. 2005a. "NonUniform Bird Assemblages in Urban Environments: The Influence of Streetscape Vegetation." Landscape and Urban Planning 71 (2-4):123-35. https://doi.org/10.1016/i.landurbplan.2004.02.006.

Whittaker, Kara A., and John M. Marzluff. 2009. "Species-Specific Survival and Relative Habitat Use in an Urban Landscape During the Postfledging Period." The Auk 126 (2):288-99. https://doi.org/10.1525/auk.2009.07136.

Whittingham, Mark J., and Karl L. Evans. 2004. "The Effects of Habitat Structure on Predation Risk of Birds in Agricultural Landscapes." Ibis 146 (November):210-20. https://doi.org/10.1111/j.1474-919X.2004.00370.x.

Wilford, John Noble. 1995. "Lovesick Woodpeckers Poke Hole in a Shuttle's Schedule." The New York Times, June 3, 1995. http://www.nytimes.com/1995/06/03/us/lovesick-woodpeckers-poke-hole-in-ashuttle-s-schedule.html.

Wolch, Jennifer, John P. Wilson, and Jed Fehrenbach. 2005. "Parks and Park Funding in Los Angeles: An Equity-Mapping Analysis." Urban Geography 26 (1):4-35. https://doi.org/10.2747/0272-3638.26.1.4.

Wolfe, Mary K., and Jeremy Mennis. 2012. “Does Vegetation Encourage or Suppress Urban Crime? Evidence from Philadelphia, PA." Landscape and Urban Planning 108 (2-4):112-22. https://doi.org/10.1016/i.landurbplan.2012.08.006. 


\title{
Chapter 2
}

\section{The efficacy of Portland Audubon's Backyard Certification Program at creating natural habitat.}

\section{Andrew Gibbs}

\begin{abstract}
The Audubon Society of Portland's Backyard Habitat Certification Program (BHCP) in Portland, Oregon seeks to enhance the urban environment for native organisms by providing individual property owners guidelines to convert yard spaces into habitat suited for native wildlife, and to certify yards as wildlife habitat. Mechanisms for achieving these goals include replacement of non-native and/or invasive plants and lawns with structurally complex native plant communities. Habitat is rated by trained observers who rate level of compliance as Silver (SV; lowest), Gold (GD), or Platinum (PT; highest). No quantitative assessment of the ecological impacts of this program has been conducted. Here I (a) determine if SV, GD, and PT yards are distinct from each other, (b) if the vegetation variation among the three types have ecological meaning, (c) the overall regional variation in landscaping patterns in Portland, (d) if restored yards of match the urban matrix, and lastly (e) if the pattern of vegetation in BHCP yards reflect a forest succession pattern reminiscent of pre-settlement landscapes. To address these questions, I sampled $1-3 \%$ of the vegetation in 147 certified and traditional yards. Using $1 \mathrm{~m}^{2}$ quadrants, I measured 46 vegetation variables within the plantable area of each at
\end{abstract}


heights of $0.0 \mathrm{~m}, 0.5 \mathrm{~m}, 1.0 \mathrm{~m}$, and $1.5 \mathrm{~m}$ and aboveground. These were reduced to 18 final measures. Landscape matrix variables were derived from LIDAR, and aerial photograph data. Analyses showed that SV, GD, and PT yards were distinct, but that overlap among SV and GD and GD and PT existed, indicating a continuum in major yard variables of lawn and native vegetation. Increasing certification level correlated with higher levels of native plants, but reduced exotics and lawn area. Distinct planting patterns exist, producing yards that were dominated by herb, shrub, tree, or lawn. Collectively landscaping patterns of BHCP yards did not match the surrounding city, but instead followed a pattern of early seral stage forest succession. The BHCP is successful at distinguishing yards of increasing vegetation structure along a continuum. It is also successful at self-replicating via outreach and required volunteerism. The program may reduce the levels of lawn and invasive plants but may also exclude yards due to the presence of invasive plants, which may actually be adequate habitat. 


\section{Introduction}

The dramatic growth of the world's human population over the last half century (United Nations 2017) has concentrated our populations in large urban centers, and for the first time in human history most people live in cities (Grimm et al. 2008). This is especially true in developed nations where the proportion of populations living in urban centers often exceeds $75-80 \%$ (e.g., $81 \%$ in the United States [U.S. Census Bureau 2010]). The consequences of the ongoing growth of urban areas for native habitats, wildlife, and humans themselves are not altogether clear, but it is widely recognized that urbanization is a major contributor to accelerating extinction rates (Sodhi et al. 2010, Biamonte et al. 2011, Duncan et al. 2011, Fattorini 2011, Aronson et al. 2014, Pievani 2014). This is in part because cities tended to be established in biotically rich locations (e.g., near the confluence of rivers or large navigable bays), but also because cities have a large footprint that greatly modifies the environment by eliminating and degrading habitats (Marzluff 2001, Foley et al. 2005, Wheeler et al 2005 Violin et al. 2011), changing local climate through heat island effects (Kalnay and Cai 2003, Dixon and Mote 2003), and altering biotic relationships among the region's native and introduced species.

But is severe loss of biotic diversity inevitable with increasing urbanization? Many species, including apex predators (Crooks and Soule 1999) and species with strict habitat and area requirements (Crooks et al. 2004), will not persist in urban areas, but other native species can tolerate and sometimes even thrive in human dominated 
habitats if at least semi-natural habitat is available (Crooks et al. 2004, Fischer et al. 2012). Avian communities in cities are undeniably shifted towards generalist species that tend to be commensal with humans (Pidgeon et al. 2014, Chace and Walsh 2006). However, with conservation efforts such as growth of greenspaces, increases in tree canopy cover in residential neighborhoods (Chapter 1), and enhanced connectivity of existing greenspaces, it may be possible to create conditions conducive to the persistence of a wide variety of native wildlife. Furthermore, considerable research has shown that the creation of lush urban environments can have positive impacts on humans as "livability" (Pataki et al. 2011, Pope et al. 2009) and property values (Tyrväinen and Miettinen 2000, Kaufman and Cloutier 2006, Kong et al. 2007.Conway et al. 2010) grow with these same efforts.

Attempts to promote healthy wildlife populations can be addressed from several scales. At the landscape level, cover of land by impervious surfaces such as roads, parking lots and city centers is probably the greatest obstacle to abundant and diverse wildlife populations (Minor and Urban 2008, Trollope et al. 2009) and thus should be minimized. At a lower spatial scale, growing evidence suggests that well treed neighborhoods support more wildlife (Melles et al. 2003, White et al. 2005, Gibbs 2018). Moreover, studies of neighborhoods in Phoenix, Arizona, showed that neighborhoods planted with mainly native vegetation supported more native birds (Lerman and Warren 2011). At the lowest logical spatial scale, is the individual home and yard. Most land in urban areas is privately owned and covered, typically, by a house or a multiunit dwelling 
and associated landscaping. What is the potential for small private land owners to create habitats that would have measurable positive influences on local biotic diversity? The typical landowner's yard is maintained as mowed grass, and it is estimated by NASA that $128,000 \mathrm{~km}^{2}$ of land in the United States is covered by lawns (Lindsay 2005). While some species may perceive lawn as suitable habitat (Marzluff 2001), lawns are for the most part biotic deserts (Burghardt et al. 2009, Bertoncini et al. 2012, but see Thompson et al. 2004). Lawn maintenance requires substantial irrigation (Haley et al. 2007), use of fertilizers and herbicides (Sewell et al. 2010), and consumption of fossil fuels because of the need to regularly cut grasses and through the industrial production of lawn maintenance products. Declines of insect pollinator (Burghardt et al. 2009) and bird populations (Thomas et al. 2004) have prompted some to ask whether conversion of "backyards" into native vegetation might create wildlife habitat to help reverse declining population trends of native animal species. Given that home range size is directly related to body size (Peters 1986), it may be possible for naturalized backyards to serve as habitable space, or corridors for smaller species of wildlife (Rudd et al. 2002, Goddard et al. 2010, Smith et al. 2015). For birds, high species richness is associated with high vertical vegetation density and structure (MacArthur 1961, Mills et al. 1991) and native vegetation (Proença et al. 2010) and therefore conversion of traditional lawn centric yards to more natural habitat may be the key to enhancing wildlife diversity, at least for smaller species, in urban environments (Belaire et al. 2014). Through collective effort of numerous landowners, the potential also exists to mitigate effects of urbanization on climate by naturalizing residential yards (Mason and Montalto 2015). 
Programs to promote yards as wildlife habitats have begun to emerge (Beumer and Martens 2015, NWF 2017). Some cities and states have official yard habitat certification programs, while elsewhere non-profit groups shoulder this responsibility. In most cities in the United States the National Wildlife Federation (NWF) "Garden for Wildlife," (NWF 2017) program is used as the basis for yard habitat certification. However, even though long-term maintenance of yards as wildlife habitat is crucial, the NWF program has no follow-up or verification of compliance for yards that they have certified. This is in stark contrast to the citizen founded yard certification program of Portland, Oregon. There strict guidelines for habitat restoration in yards have been established and they are enforced with site visits. Guidelines include detailed yard habitat features to support multiple animal groups and reduction of pesticide use and storm water runoff. The Portland program, with over 3,000 yards that have been or are in the process of being certified, has become the model now used by several cities for wildlife habitat certification.

The rigor of previous attempts to quantify yard vegetation as it relates to wildlife is variable, but generally weak. For example, Troy et al. (2007) and Boone et al. (2010) estimated yard vegetation from the street without entering the yard itself. Other studies have used poorly described methods that are not repeatable (Chamberlain et al. 2004). Other investigators have relied on self-reported data by homeowners to assess habitat (Belaire et al. 2014). By contrast, studies from New Zealand (Daniels and Kirkpatrick 2006, Kirkpatrick et al. 2007) coupled detailed quantitative studies of yard vegetation with bird surveys. Audubon Society of Portland (ASP) has developed a rigorous, onsite 
procedure for evaluating and certifying yards as silver, gold, and platinum to reflect low, medium and high conformance to program expectations. In this study, I report results of my independent quantitative analysis of yards in the ASP program using an independent set of criteria to quantify habitat structure and assess variation among the certification levels. My goals were to (a) test whether the ASP certification is repeatable using independently collected data, clear methods, and (b) to assess whether variation in yard vegetation and physical structure fall into discrete categories or vary on a continuum of ecological complexity. I also include noncertified yards in my analyses to assess how distinctive sites in the program are from yards in the same neighborhoods that are not enrolled in the ASP's program.

\section{History and Background}

In 2006 homeowners in the Hillsdale neighborhood of Portland, OR, endeavored to reduce the spread of invasive plant species onto their properties, and to encourage neighbors to do the same (West 2013). Portland, prior to westward expansion in the $19^{\text {th }}$ century, was heavily forested, primarily with upland forest and included several other forest types (Appendix B Figure 2; Christy et al. 2011). Hillsdale is adjacent to several of the remaining large natural areas that are dominated by Douglas fir (Pseudotsuga menziesii), sword fern (Polystichum munitum), Oregon grape (Berberis spp.), Trillium albidum and associated forest plant species. The natural areas and yards in this region are degraded by smothering English Ivy (Hedera spp.), Himalayan blackberry (Rubus spp.) and other species of aggressive invasive plants. The 
homeowners formed a nonprofit group originally called the Three Rivers Land Trust (TRLT), and later the Columbia Land Trust (CLT). They began a pilot program of certifying yards as free of invasive species of plants, as well as meeting other habitat criteria, such as having $10 \%$ native plants and structurally complex vegetation. The ASP inherited the program's certification efforts for the smaller yards that dominate most of the Portland region, while the CLT certifies larger yards mainly in periurban areas. The program initially targeted a small region but has grown to over 3,500 yards spread across the city, with the goal of adding 600 yards annually. Total land area in the program is $\sim 364$ ha (yards only) with an average yard being 0.104 ha in area (West 2016).

The Backyard Habitat Certification Program's (BHCP) certification criteria (Appendix B Table 1) are detailed and tiered. The three levels of certification, Silver (SV), Gold (GD), and Platinum (PT), differ in six areas meant to improve habitat. Each successive certification level includes more stringent requirements. Certification requires at least one site visit to ensure compliance. The program supports participants with access to reduced prices for purchasing native plants, names of landscaping companies that are familiar with native plant restoration, and online help with plant identification via Facebook. Once certification has been achieved the participants receive a regionally iconic metal sign (Audubon 2016).

Program requirements for vegetation have minimum criteria for percentage of plantable areas occupied by native plants: $5.0 \%$ for SV, $15.0 \%$ for GD, and $50.0 \%$ for PT. In addition, yards are expected to have multiple (5) vegetation levels, such as tree canopy, and understory canopy (Appendix B Figure 1), however there is no measure of 
the percentage cover at each level. Abundant evidence indicates that increasing vegetation volume and heterogeneous multi-leveled habitat increases the abundance and species richness of arthropods (Mclntyre et al. 2001, Sattler et al. 2010), mammals (McShea et al. 2003, Stephens and Anderson 2014), and birds (White et al. 2005, Hovick et al. 2014, and Bergner et al. 2015). Further work has shown that native plants also enhance native insect species' reproduction (Fiedler and Landis 2007, Gerber et al. 2008), and urban arthropods respond to local vegetation variables (Philpott et al. 2014). BHCP guidelines attempt to fill these needs. They include the Portland Oregon Plant List, which describes how each plant is expected to fit into the food web of the local animal community (Portland 2016), which is critical as native plants may provide more and higher quality food than exotic species (French et al 2005).

Some certification requirements are not directly related to wildlife. Pesticide reduction encourages use of lower toxicity pesticides, and encouragement to use an Integrated Pest Management program (IPM) as described by the Environmental Protection Agency (USEPA 2016). Storm water management is intended to reduce chemical flow from urban areas into local water ways. Wildlife stewardship criteria involve adding specific nonliving materials, such as wood snags and piles of dead branches, as potential nesting locations for reptiles, birds, mammals, and arthropods. Certification as PT also includes education and volunteerism criteria intended to enhance the gardening and ecological knowledge of participants to, ultimately, increase the pool of volunteers helping with the BHCP. 


\section{Methods}

\section{Time Period}

I quantified habitat structure of each yard once during the summer of 2013,2014 , or 2015 between the $15^{\text {th }}$ of July and the $20^{\text {th }}$ of September, except for 2013 when three sites were surveyed in early October. Ultimately, leaf fall in autumn determined the end of data collection each year. Sites where landscaping changed dramatically during the study period were not included.

\section{Site Selection}

Initial contact with the entire pool of certified yard owners was made by an ASP representative who used a flier I developed. Interested people contacted me via e-mail, and at that point ASP involvement ended. More than 500 homeowners offered to take part. From this pool I chose study sites in pre-determined regions of the city with a range of tree canopy cover, from areas with low (0-50\%) to high cover (50\% to $80 \%$ ). This method was blind to certification level. There were more yards at the lower certification levels in the program, and hence in the study. Non-certified yards were recruited via neighborhood association meetings, publicized public meetings for this purpose, and by asking BHCP participants already in the study to recruit neighbors with non-certified yards. Although avian survey data were collected from 200 yards, time allowed for only 151 to be surveyed for vegetation (Fig. 2.1). Four of the 151 were much larger than all others and for this reason I excluded them from the analysis. 


\section{Vegetation Data Collection}

Total percent cover, and percent cover of native and exotic herbaceous plants (herbs), shrubs and trees were collected at $0 \mathrm{~m}, 0.5 \mathrm{~m}, 1.0 \mathrm{~m}$ and $\geq 1.5 \mathrm{~m}$ above ground. Native plants were those listed on the Portland Plant List, which lists plants endemic to the Willamette Valley. An exotic plant was any plant outside this list with the exceptions of grasses maintained as lawns, which were collectively listed as "lawn". Percent cover of ground variables including bare ground, mulch, stone, stump, tree base, fine litter, moss, lichen, and lawn were visually estimated.

To delineate the area of each measurement point I used a 1- $\mathrm{m}^{2}$ square quadrat, and a modified Robel pole (Robel et al. 1970) to measure vegetation structure at the heights listed above. Plantable area was calculated by measuring and adding the area of various plantable patches at each residence. Gravel and mulch were included as plantable space, but large patches of impervious surface or decks blocking access to the soil were not. Gravel, landscaping rocks, and isolated stepping stones encountered at a sampling point were recorded as stone. I set a maximum of 16 quadrats per yard, which means $3 \%$ of the surface of yards with less than $533 \mathrm{~m}^{2}$ was sampled, between $1 \%$ and $3 \%$ of a yard was surveyed for yards between $533 \mathrm{~m}^{2}$ and 1,600 $\mathrm{m}^{2} ; 8$ of 147 surveyed yards were greater than $1,600 \mathrm{~m}^{2}$, but all were less than $3,000 \mathrm{~m}^{2}$. Number of quadrats needed for each yard was calculated by determining $3 \%$ of the area for each yard, up to $533 \mathrm{~m}^{2}$, and stopping at the 16 quadrat limit. The section of yard where quadrats were to be located (either the front, back, or side) was determined by the percentage of the total plantable area they occupied. The location of each quadrat was determined 
randomly by interpreting the length and width of each section of yard as $X$ and $Y$ coordinates. Random coordinates for the $\mathrm{X}$ and $\mathrm{Y}$ axes were then generated using a random number generator. Survey time varied from 2 to 6 hours per yard.

Within each quadrat the percent cover of each ground variable was collected and then herb, shrub, and tree measurements were visually estimated at each of the other heights. Above $1.5 \mathrm{~m}$, tree cover was taken by standing at each of the 4 quadrat corners, looking up, and estimating the percent area covered by tree branches and leaves. This gave a total for each type of vegetation overhead, similar to the BHCP vegetation layer estimates. Data from all individual quadrats within a yard were averaged to create a single mean for each variable for each back yard. The measurements at each height were then summed. A total of 45 individual measurements (Table 2.2) were taken at each site, including measurements at each of the 3 heights, yielding the final individual yard variables: total herb, total shrub, total tree, total native herb, total native shrub, total native tree, total exotic herb, total exotic shrub, and total exotic tree. There were 18 survey variables: 9 for herbs, shrubs, and trees, and 9 for ground cover. To compare yards to the urban matrix, publicly available landscape data were collected to generate variables for grass and herbaceous land cover, and tree canopy cover. These were calculated for a 500 m radius circle centered on each yard using the buffer tool of ArcGIS (ESRI 2015). LIDAR canopy raster data from Portland Metro (Portland 2014) were reclassified assigning a 1 or 0 to pixels with or without canopy cover, respectively. Area of canopy was calculated using the Tabulate Area 2 tool within the $500 \mathrm{~m}$ buffer circles. Grass and herbaceous landcover data from 
the US EPA (US EPA 2015) and the Tabulate Area 2 tool were used in the same manner to create the grass and herbaceous cover for the $500 \mathrm{~m}$ radius circle.

\section{Statistical analysis}

I used several methods to test for differences in the mean values of yard variables among SV, GD and PT yards. Means were compared with an ANOVA. I report mean \pm SE for each variable, and $p$-value for any that differed significantly among yard classifications. I report the overall mean and the p-value of the ANOVA F-ratio for the significance of certification alone as a model effect. I used discriminant function analysis to test the ability of the predictor variables to correctly classify yards into their stated certification types. I did this both with and without the NC yards included in the analysis. Principal component analysis based on a correlation matrix was used to describe major gradients of variation in vegetation structure in yards without consideration of yard certification. For this I used all variables that had means of $10 \%$ cover or higher for the average yard; this excluded several of the rare ground cover variables.

An implicit assumption of any yard restoration program is that wildlife responds directly to habitat within the yard space, but it is possible that the surrounding landscape has a more important influence on the animals using a given yard.

Mismatches between yards and surrounding landscape therefore have the potential to undermine the ability of yard restoration to benefit wildlife. To test for how well individual yards matched the surrounding landscape, I compared the yard variables total herb, total shrub, total tree, and lawn to landscape variables canopy and 
grass/herbaceous cover obtained for a $500 \mathrm{~m}$ radius circle centered on each yard. I used principal component analysis and Pearson correlation analyses to determine the relationships among yard and landscape variables. Analyses were run as both a single set combining all yards as well as all yards grouped by certification levels to determine if matrix matching was a property of certification.

\section{Results}

Eight variables differed significantly among SV, GD and PT yards while two others were marginally nonsignificant (Table 2.2). PT yards had significantly less lawn, and more total tree canopy, native trees, and native herbaceous plants (Table 2.2). GD yards had more shrub cover than NC or SV (similar to PT yards), but less area covered by stumps than PT yards. SV yards had less bare ground, fine litter, tree canopy and native shrubs than both GD and PT yards. NC yards had the greatest amount of lawn, and less cover by shrubs and native shrub than all certified yards except for SV yards.

To describe overall covariation of habitat variables among yards, I conducted a principal component analysis of variables that, on average, had a percent cover of at least $10 \%$ without drawing the distinction between native and exotic plants. This included bare ground, fine litter, lawn, mulch, herb, shrub, and tree. Eigenvalues for the first four eigenvectors (i.e., principal components [PC]) exceeded 1.0 and explained $80 \%$ of the variation in habitat structure among yards (Table 2.3). An ANOVA of the PC1, PC2, and PC3 mean values among the four yard types showed no significant differences, both 
with and without not-certified yards. PC1 was a contrast of yards dominated by lawns (negative scores) with those dominated with cover of fine litter and abundant shrubs and especially trees (positive scores; Table 2.3). On PC2, yards with negative scores contained little bare ground or tree cover but abundant cover by mulch; whereas yards with positive scores lacked mulch but bare ground but herbaceous vegetation and tree cover were high. Component 3 was a contrast of yards with abundant lawn but little cover by herbaceous vegetation or bare ground (negative scores) with yards of the opposite condition of little lawn, but abundant bare ground and/or herbaceous vegetation. Finally, PC4 mainly contrasted yards that were dominated by either herbaceous plants or few shrubs (negative scores) with those where herbaceous vegetation was replaced by shrubs (positive scores).

The DFA, which used the nine variables identified by the ANOVA as differing among yard categories, correctly assigned nearly $70.0 \%$ of sites to their proper category when only certified yards were included in the analysis (Table 2.4). Similar proportions of SV and PT yards were correctly classified ( 75\%), but GD yards were somewhat lower. Within each category, comparison of the observed to the expected number of yards assigned to each category, assuming random assignment, showed that significantly more yards were assigned correctly than expected by chance in 2 of 3 cases (Table 2.4); PT yard classifications were not different from random, but that was likely a consequence of small sample size because PT yards had the highest percentage correct classifications (Table 2.4). Including the NC sites reduced the proportion of correctly assigned sites to 50.3\%; PT sites were the least affected, but misclassification increased 
for all categories mostly because misclassified NC yards were often placed into the SV and GD categories (Table 2.4). Nonetheless, most SV, GD and PT yards were placed in their proper category and in 2 of 4 cases the percentage of sites assigned correctly was better than random (Table 2.4).

Correlations of the four primary yard variables (cover by lawn, herbaceous vegetation, shrubs, and trees) with the proportion of the surrounding landscape that was covered either by trees or low vegetation (grass/herbaceous vegetation) were not strong. Indeed, only tree cover in yards varied with landscape variables when all sites were combined (Table 2.5), but $<7 \%$ of tree cover in yards could be accounted by landscape tree cover or landscape grass/herbaceous cover (Table 2.5). Separate analysis for all four yard categories showed that uncertified yards exhibited more significant associations with landscape variation in tree and grass/herbaceous cover (6 of 8 correlations significant) than any of the yards in the program, but again, the strongest correlation indicated that only $17 \%$ of variation in lawn cover within yards could be accounted for by landscape tree cover. Thus, habitat structure within yards was relatively independent of the character of the surrounding matrix (Table 2.5). Habitat of yards tended to be somewhat more strongly related to canopy cover at the landscape level (9 significant correlations) than with grass/herbaceous cover (6 significant correlations; Table 2.5). The overall strongest relationship was an inverse correlation between tree canopy cover in yards and grass/herbaceous cover in the landscape for SV yards (Table 6), while the strongest positive correlation was between shrub and canopy in PT yards (Table 2.5). 


\section{Discussion}

The primary purposes of the BHCP are to reduce the spread of invasive plants, and to increase the level of suitable wildlife habitat in the city by promoting the eradication of invasive plants and lawns in favor of increased cover by native trees and other native plants. The three levels of certification used by the BHCP, the strict adherence to requirements for minimum levels of native plants, and reliance on well trained volunteers to conduct onsite evaluations should create, all else being equal, a program that moves yards through a progression of increasing vegetation structure and representation of native plants.

The independent data collected in this study generally suggest that the program is meeting the objectives. Although no "pre-certification" vegetation data were available to conduct before-after comparisons of vegetation, it seems likely that the BHCP is achieving its goals. This is valuable as yards maintained as lawn provide few resources for wildlife because both mowing and leaf-blowing are designed to remove organic material. Maintaining lawn also contributes to waterway pollution (Morton et al. 1988) as the dense root and compacted soil structure is little better than impervious surface for absorbing rain or irrigation water (Yufen et al. 2008, Bedan and Clausen 2009). Lawn is, however, much more effective than bare soil at reducing run-off (Blanco-Canqui et al. 2004) and is valuable as an erosion control method (De Baets et al. 2006). My results indicate that NC and SV yards had very similar levels of native vegetation, with both 
being well below that typically found in GD and PT yards. While it is possible that these yards contained adequate levels of native plants before involvement in the program, the BHCP quantitative measures are successful at identifying yards with increasing levels of native plants and may be effective at encouraging native plantings.

One goal of the expansion of native plantings is to provide potential habitat for native lepidoptera. Many lepidopterans require native host plants to reproduce, and many exotic plants used in yards are resistant to herbivory by insect herbivores (Tallamy and Shropshire 2009, Burghardt et al. 2010). Native lepidopteran larvae are critical food for nestling songbirds. Thus, the difference between BHCP yards and yards with dominance of space by lawns is increased herb and shrub vegetation, which increases the overall volume of habitat available to all wildlife. However, it is unknown if the program itself has resulted in a substantial increase in native vegetation because there is no way to know if any of the certified yards had certifiable levels of native plants before entering the program. The fact that most yards enter the program at the SV (or lower) but then advance to higher levels after reevaluation (West 2016) suggests strongly that the program does in fact promote native plantings (West 2016).

My analyses suggest that the certification program's discrete categories of SV, GD and PT are somewhat artificial as considerable overlap in vegetation structure among yard levels exists. For instance, the scatter plot of the first and second canonical axes from the DFA (Figure 2.4) showed good separation of the centroids for each yard type, but also considerable overlap. Most overlap occurred between either SV and GD, or GD and PT, and very little between SV and PT, suggesting that a yard entering the 
program is on a trajectory of continued improvement, but this is only speculation given the absence of data on pre-certification yard structure. Participants in the lower tier of certification need to receive encouragement and support to continue to improve their yards so that advancement to higher tiers of greater potential wildlife habitat occurs.

SV and PT yards were separated mainly by the variables contributing to the first axis of the DFA, which is the axis defining the primary gradient from yards with either traditional lawn or mulch and few trees to yards with highly structured and complex vegetation. While GD yards were intermediate, they overlapped considerably with both SV and PT yards on axis 1. Additional separation of GD yards from the other yard types occurred on the second axis of the DFA, indicating that GD yards tended to have greater cover by native shrubs than either SV or PT yards, suggesting a possible intermediate stage in yards in their gradual transformation from lawn to herbaceous/shrub cover to the more typical high tree cover of PT yards. NC yards overlapped with all certification levels (Table 2.4). This likely indicates that some non-certified yards already possessed the desired qualities of the BHCP program and supports the possibility that at least some certified yards entered the program at a level that required little additional landscaping. In such cases the BHCP, instead of helping to create wildlife habitat de novo serves as the entity that recognizes and rewards those that already have many of the desired conditions.

I selected sites without regard to existing yard vegetation and some were pending certification. Some of these yards almost certainly contained invasive plants, which immediately makes them uncertifiable because certain invasive plants like 
Himalayan blackberry or English ivy automatically exclude yards from certification. However, some of these yards may also have abundant native vegetation and acceptable vegetation structure. Such yards, although tainted by the presence of invasive species, may support wildlife, even partially because at least some invasive plants provide benefits for wildlife, including food (Schmidt and Whelan 1999, Brown 2002) or nesting sites (Gaire et al. 2015). Thus, the overlap of NC yards with all other yard types might include some yards with wildlife friendly habitat, and certainly reflects the wide range of yard landscaping that exists in Portland outside the BHCP.

The PCA showed several trends that may indicate human preference for creative planting styles, which may possibly inform future efforts of yard-based habitat restoration. While some of the components may not be statistically interpretable (Manly 1984, Jolliffe 2016), it is useful to discuss them, as the lack of correlations reveals an important pattern. Yards represent continuums as shown with the DFA, but individual yards tended to be dominated by one or two categories of the four major plant types: lawn, herbs, shrubs and trees. For instance, PC1 represented the primary gradient describing the continuum from traditional yards with considerable lawn to yards dominated by high cover of trees or shrubs. PC2 contrasted yards that had either few trees and abundant mulch with yards in which bare ground replaced mulch and tree cover increased. Loadings of variables on PC3 indicated that yards with abundant lawn were contrasted with yards dominated by a combination of high shrub cover and/or bare ground, while the primary contrast on PC4 was of yards dominated by either high herbaceous plant cover or shrubs. The progression from PC1 through PC4 thus suggests 
that the contribution of tree cover to variation in vegetation structure of yards declined and at the same time there was a gradual transition from yards dominated by lawns to mulch/bare ground to, eventually, herbaceous plant cover. Thus, trees were the most crucial factor differentiating yards while ground cover played a secondary role. The patterns lend themselves to broad groupings of "lawn," "herb," "shrub," or "tree" yards along a continuum. In a sense, yards in human managed landscape seemed to roughly follow a trajectory of forest succession going first through yards dominated by grasses to herbaceous plants, then small shrubs and finally young trees. Trees in any situation grow slowly and a newly restored yard may lack trees all together yet have lawn and a few herbaceous plants. Planting will remove some lawn, but the exposed area may not be suitable for many of the shade preferring herbaceous plants of the Portland region. Only once trees grow and a canopy is established can native herbaceous and shade loving plants be established.

Residential yards in Portland were not landscaped to match the surrounding city; nor were they landscaped to contrast with it. Rather, yards most likely reflected the individual preferences of homeowners, which can be affected by nearly endless variables. Any one home is surrounded by vegetation in other yards, city parks, and street plantings. Owners interested in restoration may be inclined to attempt to replace plant types that are missing locally, and hence are different from the matrix. People not interested in restoration may prefer lawn in regions with trees to allow for simple yard maintenance. Some yard owners may try to mimic their neighbors instead of focusing on the city scale of the landscape (Zmyslony and Gagnon 1998). The primary function of 
residential yards, in almost all cases, is to serve for habitat for humans with wildlife, in most cases, a distant second at best. Even though I worked with yards in the BHCP, they were designed to provide resources for humans. A visually stimulating environment for recreation, gardens for food, an area to hang drying laundry, and a place to do dirty chores are common yard components. While a yard dense with shrubs and herbs may provide the best habitat for birds, it limits use of the space by humans. Many yards in the study have areas that are nearly inaccessible to humans due to dense shrub and herb vegetation, but all contain aspects to encourage human use of the space. The personal and creative nature of landscaping, even when guided by strict requirements, creates a situation where it is unlikely that a yard will match the surrounding urban vegetation.

My independent examination of the Portland BHCP shows that the program segregates yards into categories of increasing habitat structure and levels of native plants consistently, but that vegetation structure of yards in the program fall along a continuum of increasing vegetation structure and complexity. Our desire for discrete categorization of yards, while understandable, is not truly possible. My research has also shown that NC yards often share features with SV and GD yards, but that they may be excluded solely because of the program's requirement that all invasive and many nonnative plants be eliminated regardless of whether wildlife benefit from their presence. While it may be true that some species prefer native plants (French et al. 2005), this is not true in all situations. For instance, in Shipley et al. 2013 they found that Spotted Towhee (Pipilo maculatus) fledglings spent most of their time hiding in Himalayan 
blackberry patches, possibly because it provided substantial protection from predators, fruit, and abundant arthropod forage.

Few other yard certification programs involve the level of detail and verification of compliance as the BHCP. The most widely used program in the United States is the "Garden for Wildlife" managed by the non-profit National Wildlife Federation (NWF 2017). Many local programs, such as in the state of Delaware (Delaware Nature Society 2017), adopt the NWF criteria. While the NWF program has requirements like the BHCP (Appendix B Table 3), they are simple, not specific to each region or habitat, and do not encourage removal of listed invasive species. The NWF certification program requires completing a website questionnaire, and paying a fee which increases depending on which type of lawn sign a participant is interested in. There are no visits and there is no verification of compliance. However, not all local efforts are without logical consideration of local vegetation. There are programs such as that found in San Jose, CA (San Jose 2017) that provide local native plant guidance without inspection. Audubon chapters in Tucson, AZ (AST 2017), and Atlanta, GA (ASA 2017), have recently adopted programs based on the BHCP with on-site certifications, and the National Audubon Society maintains a regionally specific database for bird-friendly native plants (Audubon 2017).

The final and critical piece to the BHCP is the built in self-replication mentioned above. The small BHCP paid staff at the ASP (1 person), and several volunteers there and at the CLT cannot manage, promote, and grow such a large program. To meet the needs and goals of the program, participants at the PT level are required to annually fulfill one 
of several criteria that serve to support the program in outreach, education of the public, expansion of the program, and assist with certification of new program yards. PT participants must showcase their yard in an annual citywide event, participate in education programs, be trained as a Master Gardener (OSU 2017) or volunteer for the BHCP. The trained volunteers who certify the yards are frequently PT level yard owners who have been trained as "Master Gardeners". PT yard owners are also expected to recruit neighbors for the program. The potential for this program to expand its outreach is thus limited mainly by human resources, and without growth of the program, the impact of any individual homeowner to positively affect wildlife is limited. Thus, an increase in human resources for "boots on the ground" involvement is the key to increase the impact of backyard habitat on urban wildlife conservation. 


\section{Chapter 2 Figures and Tables}

Figure 2.1 Study area for sampling of birds, and habitat variables from random locations (green circles) and yards (blue circles). The orange line and pink region indicate the study area. Portland, OR is outlined by a thick black line and is bordered by Vancouver WA, Gresham OR, Lake Oswego OR, Tigard OR, and Beaverton OR (clockwise from the north). The Willamette River divides Portland into east and west halves, while Burnside Street separates north from south Portland. A northwest turn in the Willamette River separates Northwest Portland (NW) from North Portland (NP). Green lines below follow these landmarks and divide the indicated regions NW, NP, Northeast Portland (NE), Southeast Portland (SE), and Southwest Portland (SW).

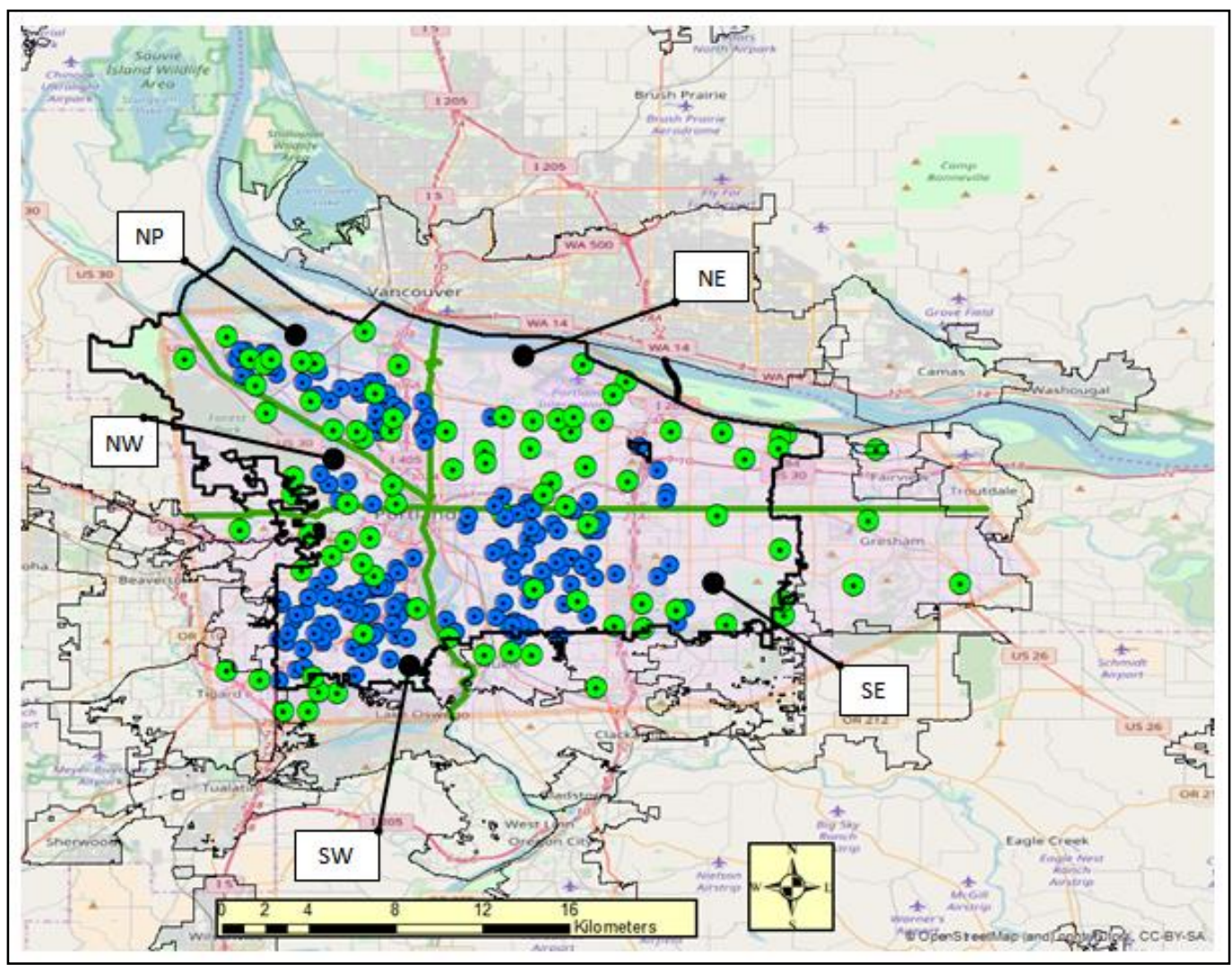


Table 2.1. List of yard and landscape variables collected at 147 yards in Portland

Oregon.

\begin{tabular}{|c|c|}
\hline & Yard Variables \\
\hline $\mathbf{0 . 0}$ m Only & $\mathbf{0 . 5 m} / \mathbf{1 . 0} \mathbf{~} \mathbf{~ / 1 . 5 ~} \mathbf{~}$ \\
\hline Planted Area & Exotic and Native Herb \\
\hline Log & Exotic and Native Shrub \\
\hline Stone & Exotic and Native Tree \\
\hline Stump & Total Herb \\
\hline Tree Base & Total Shrub \\
\hline Fine Litter & Total Tree \\
\hline Total Moss & \\
\hline Total Lichen & Landscape Variables \\
\hline Lawn & 500 m LIDAR Canopy \\
\hline Mulch & $500 \mathrm{~m}$ Grass/Herbaceous \\
\hline
\end{tabular}


Figure 2.2: Least square means of 18 variables in 33 Silver, 55 Gold, and 13 Platinum yards in the Audubon Society of Portland's Backyard Habitat Certification Program.

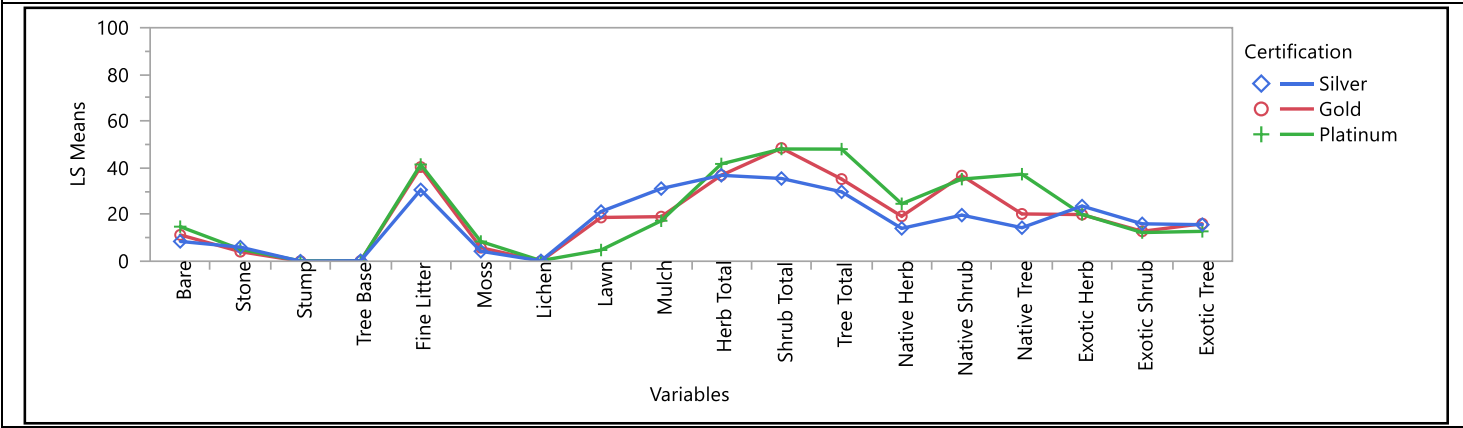

Figure 2.3: Least square means of 18 variables in 46 Not Certified, 33 Silver, 55 Gold, and 13 Platinum yards in the Audubon Society of Portland's Backyard Habitat Certification Program.

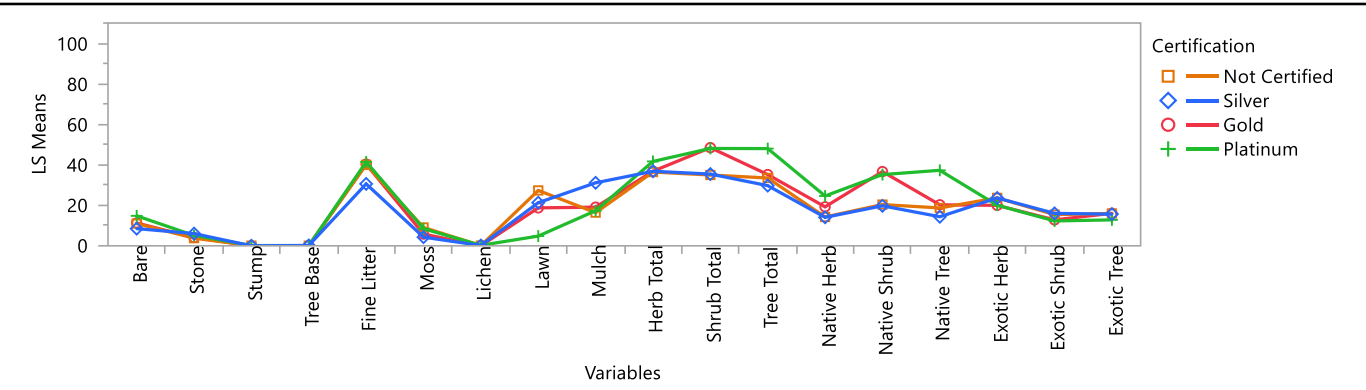


Figure 2.4: Scatter plot of canonical axis 1 and canonical axis 2 of a discriminant function analysis (DFA) of 33 Silver (orange circles), 55 Gold (green circles), and 13 Platinum (blue circles) yards in the Audubon Society of Portland's Backyard Habitat Certification Program. The 9 Included variables (Table 2.3) varied significantly among the yard types for at least one certification level. The two primary canonical iaxis of the DFA maximally separate the certification groups, and the rays of the plot indicate the degree of association that the covariates (vegetation variables).

The + at the center of the two circles indicates the point of each multivariate mean. The inner circle is the $95 \%$ confidence interval for each mean, while the outer circle contains $50 \%$ of the samples (yards) for each group.

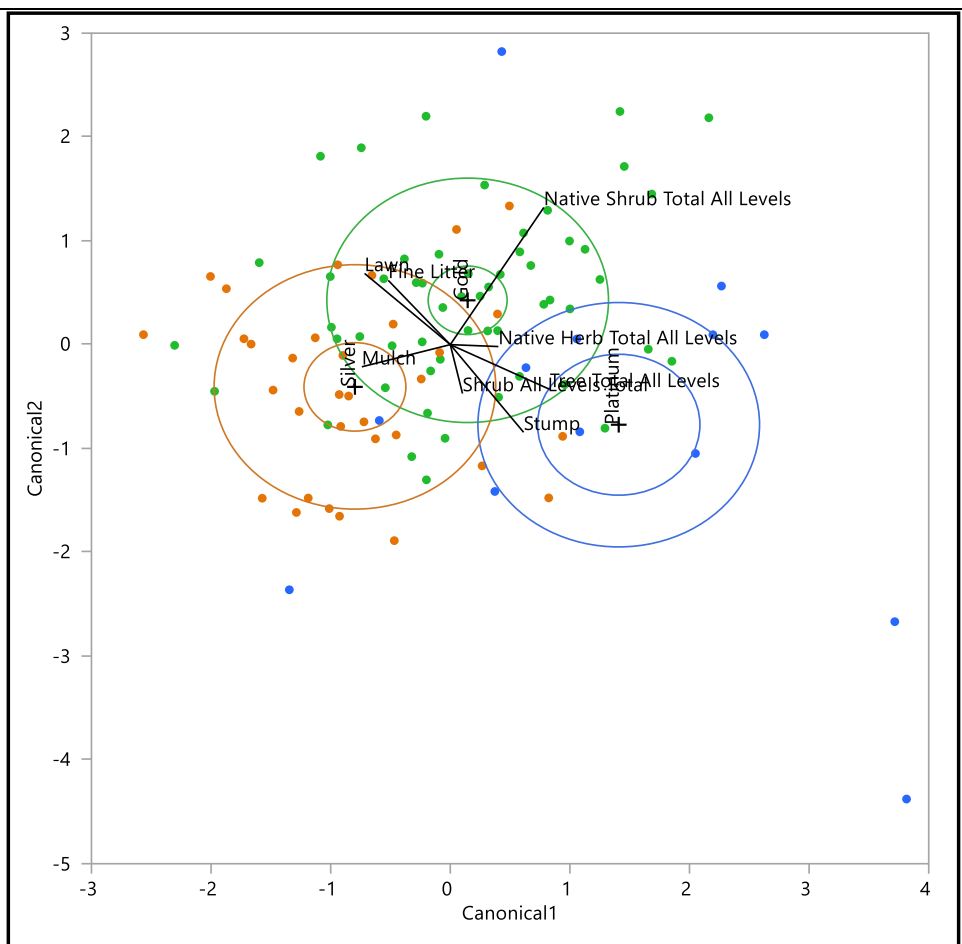


Table 2.2: Means standard error, and ANOVA by certification level for the 18 final yard variables in 46 Not Certified (NC), 33 Silver (SV), 55 Gold (GD), and 13 Platinum (PT) yards in the Audubon Society of Portland's Backyard Habitat Certification Program. Means which are significantly different $(p<0.05)$ are in bold. The overall mean (MEAN), is also given as well as the F-ratio and alpha $(F[P])$ of the F-ratio for the effect of certification.

\begin{tabular}{|c|c|c|c|c|c|c|}
\hline Variable & $\mathrm{NC}$ & SV & GD & PT & MEAN & $(F[P])$ \\
\hline $\begin{array}{l}\text { Bare } \\
\text { Ground }\end{array}$ & $10.97 \pm 1.28$ & $\begin{array}{c}8.48 \pm 1.52 \\
(0.035)\end{array}$ & $11.28 \pm 1.18$ & $14.80 \pm 2.42$ & 10.869 & $\begin{array}{c}1.74 \\
(0.161)\end{array}$ \\
\hline Stone & $3.79 \pm 0.97$ & $6.04 \pm 1.15$ & $4.10 \pm 0.89$ & $5.12 \pm 1.83$ & 4.529 & $\begin{array}{c}0.88 \\
(0.454) \\
\end{array}$ \\
\hline Stump & $0.09 \pm 0.03$ & $0.01 \pm 0.04$ & $\begin{array}{c}0.004 \pm 0.03 \\
(0.038)\end{array}$ & $0.15 \pm 0.06$ & 0.047 & $\begin{array}{c}2.77 \\
(0.043)\end{array}$ \\
\hline Tree Base & $0.09 \pm 0.04$ & $0.18 \pm 0.05$ & $0.10 \pm 0.04$ & $0.10 \pm 0.08$ & 0.116 & $\begin{array}{c}0.67 \\
(0.570)\end{array}$ \\
\hline Fine Litter & $40.01 \pm 2.82$ & $\begin{array}{c}30.57 \pm 3.33 \\
(0.013)\end{array}$ & $40.34 \pm 2.58$ & $41.42 \pm 5.31$ & 38.142 & $\begin{array}{c}2.23 \\
(0.087)\end{array}$ \\
\hline Moss & $9.05 \pm 1.33$ & $4.27 \pm 1.57$ & $5.80 \pm 1.22$ & $8.44 \pm 2.51$ & 6.707 & $\begin{array}{c}2.17 \\
(0.094) \\
\end{array}$ \\
\hline Lichen & $0.12 \pm 0.07$ & $0.16 \pm 0.08$ & $0.05 \pm 0.06$ & $0.25 \pm 0.13$ & 0.115 & $\begin{array}{c}0.84 \\
(0.470) \\
\end{array}$ \\
\hline Lawn & $\begin{array}{c}27.34 \pm 2.68 \\
(0.0004)\end{array}$ & $21.29 \pm 3.17$ & $18.74 \pm 2.45$ & $\begin{array}{c}4.81 \pm 5.05 \\
(0.001)\end{array}$ & 20.772 & $\begin{array}{c}5.57 \\
(0.001)\end{array}$ \\
\hline Mulch & $16.38 \pm 3.25$ & $\begin{array}{c}31.11 \pm 3.84 \\
(0.004)\end{array}$ & $19.09 \pm 2.97$ & $17.33 \pm 6.12$ & 20.786 & $\begin{array}{c}3.24 \\
(0.024)\end{array}$ \\
\hline Herbaceous & $36.42 \pm 2.59$ & $36.80 \pm 3.07$ & $36.81 \pm 2.37$ & $41.67 \pm 4.90$ & 37.116 & $\begin{array}{c}0.32 \\
(0.808) \\
\end{array}$ \\
\hline Shrub & $\begin{array}{c}34.97 \pm 3.29 \\
(0.034)\end{array}$ & $35.44 \pm 3.88$ & $\begin{array}{c}48.46 \pm 3.01 \\
(0.027)\end{array}$ & $48.07 \pm 6.18$ & 41.279 & $\begin{array}{c}4.29 \\
(0.006)\end{array}$ \\
\hline Tree & $33.49 \pm 2.78$ & $\begin{array}{c}29.72 \pm 3.28 \\
(0.02)\end{array}$ & $35.18 \pm 2.54$ & $\begin{array}{c}48.01 \pm 5.23 \\
(0.006)\end{array}$ & 34.560 & $\begin{array}{c}2.99 \\
(0.033)\end{array}$ \\
\hline Exotic Herb & $23.69 \pm 2.18$ & $23.63 \pm 2.58$ & $19.99 \pm 2.00$ & $20.04 \pm 4.10$ & 21.969 & $\begin{array}{c}0.75 \\
(0.525)\end{array}$ \\
\hline Native Herb & $14.24 \pm 2.02$ & $14.06 \pm 2.38$ & $19.25 \pm 1.85$ & $\begin{array}{c}24.60 \pm 3.80 \\
(0.03)\end{array}$ & 16.992 & $\begin{array}{c}2.96 \\
(0.035)\end{array}$ \\
\hline $\begin{array}{l}\text { Exotic } \\
\text { Shrub }\end{array}$ & $15.40 \pm 2.14$ & $16.03 \pm 2.53$ & $12.81 \pm 1.96$ & $12.29 \pm 4.03$ & 14.299 & $\begin{array}{c}0.52 \\
(0.671) \\
\end{array}$ \\
\hline $\begin{array}{l}\text { Native } \\
\text { Shrub }\end{array}$ & $\begin{array}{c}20.37 \pm 2.60 \\
(0.003)\end{array}$ & $\begin{array}{c}19.74 \pm 3.07 \\
(0.003)\end{array}$ & $\begin{array}{c}36.65 \pm 2.38 \\
(0.004)\end{array}$ & $\begin{array}{c}35.17 \pm 4.90 \\
(0.064\end{array}$ & 27.628 & $\begin{array}{c}10.37 \\
(<0.001)\end{array}$ \\
\hline Exotic Tree & $15.97 \pm 2.17$ & $15.644 \pm 2.57$ & $16.05 \pm 1.98$ & $12.80 \pm 4.09$ & 15.647 & $\begin{array}{c}0.18 \\
(0.908)\end{array}$ \\
\hline Native Tree & $18.69 \pm 2.67$ & $14.36 \pm 3.15$ & $20.25 \pm 2.44$ & $\begin{array}{c}37.28 \pm 5.02 \\
(0.003)\end{array}$ & 19.944 & $\begin{array}{c}5.10 \\
(0.002)\end{array}$ \\
\hline
\end{tabular}




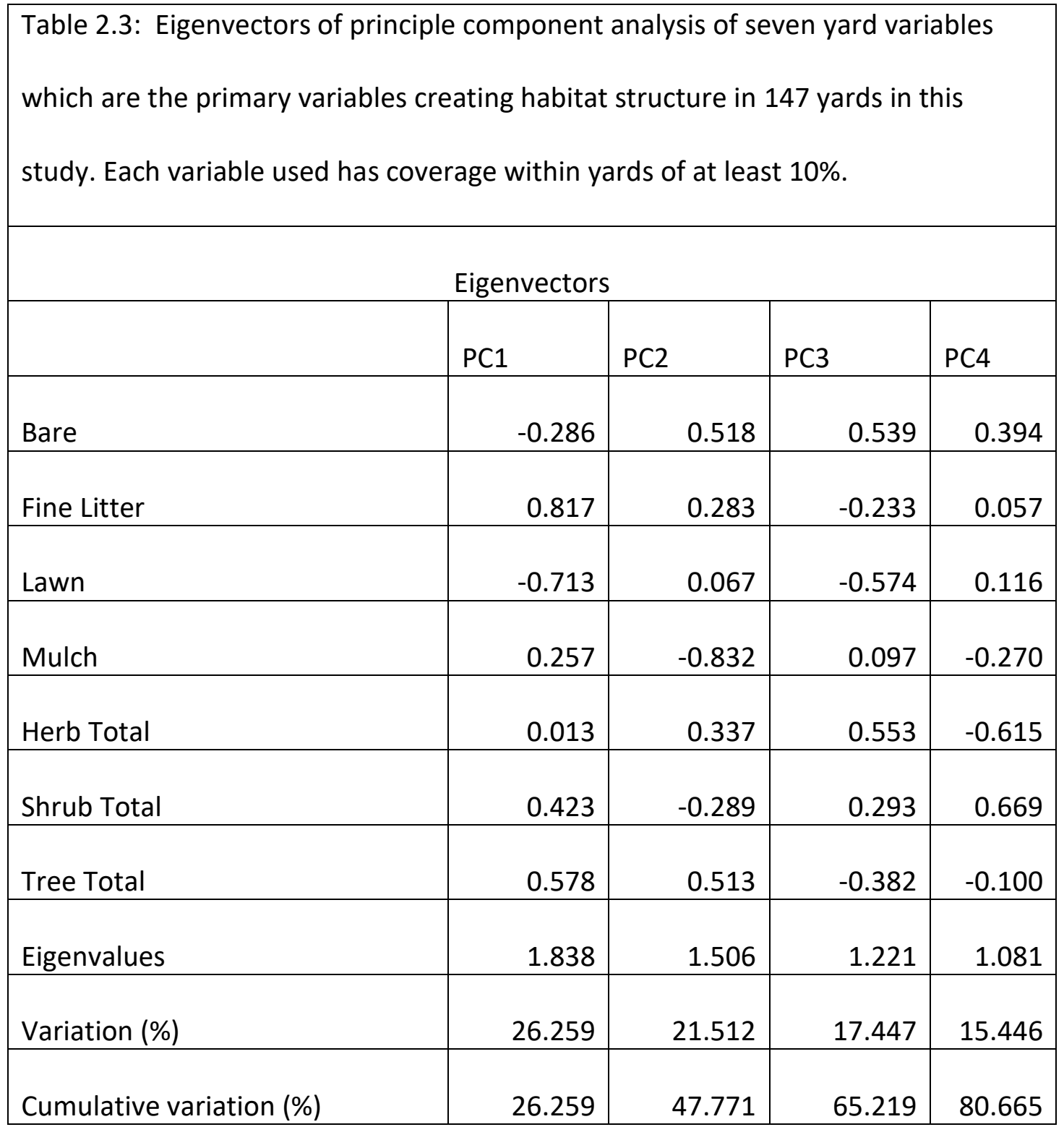




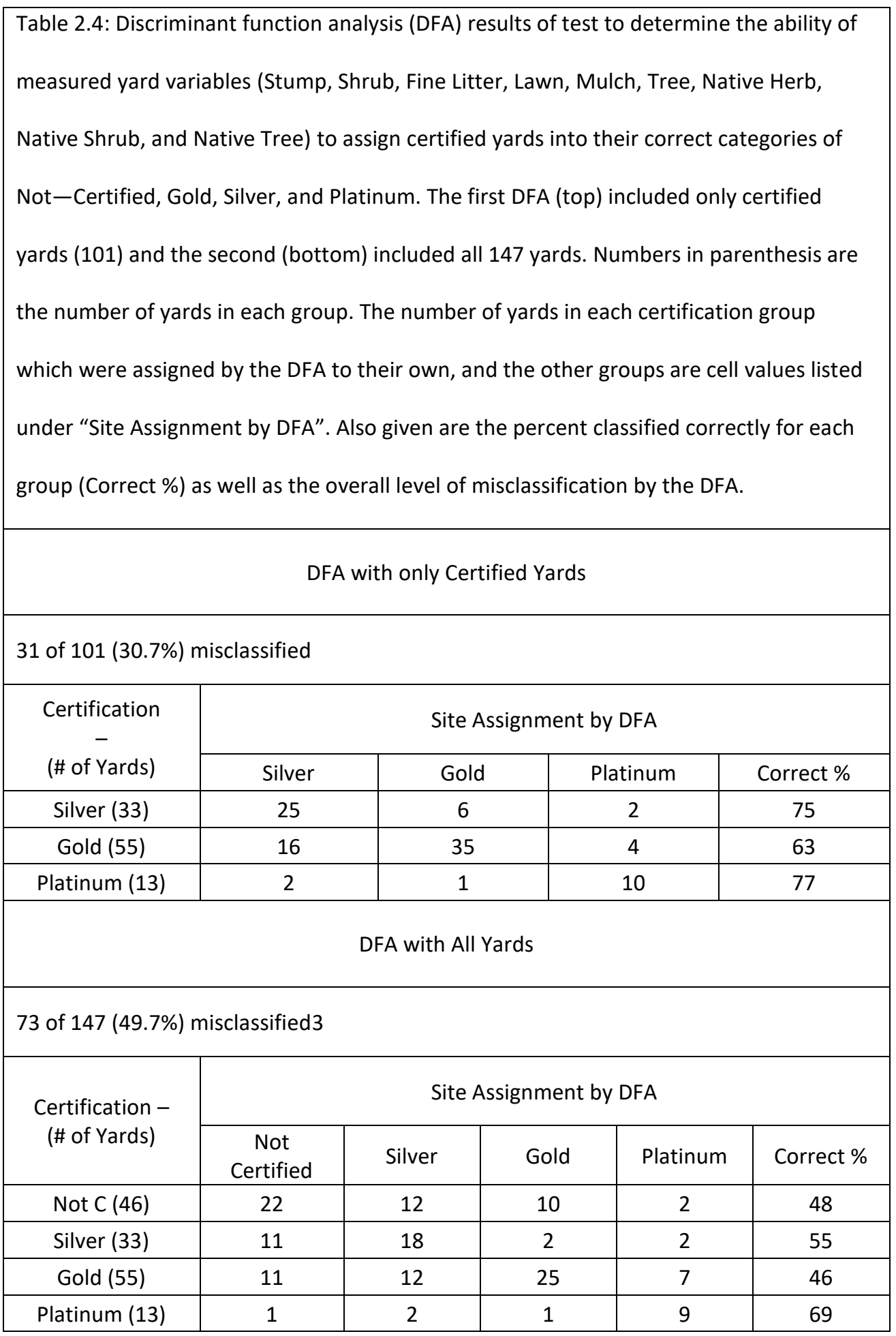




\begin{tabular}{|c|c|c|}
\hline \multicolumn{3}{|c|}{$\begin{array}{l}\text { Table 2.5: Correlations among } 4 \text { yard vegetation structure variables lawn, herb, } \\
\text { shrub,and the } 2 \text { landscape variables canopy } 500 \mathrm{~m} \text { and grass and herbaceous plants } 500 \\
\mathrm{~m} \text {. Significant correlations }(\mathrm{P}<0.05) \text { are underlined and bold. Correlations are presented } \\
\text { for each certification level, with the number of sites in each level in parenthesis, as well } \\
\text { as for all yards as a group. }\end{array}$} \\
\hline & Canopy 500 & Grass/Herb 500 \\
\hline \multicolumn{3}{|c|}{ Not Certified (46) } \\
\hline Lawn & -0.417 & $\underline{0.347}$ \\
\hline Herb & $\underline{0.353}$ & $\underline{-0.300}$ \\
\hline Shrub & 0.104 & -0.099 \\
\hline Tree & $\underline{0.328}$ & $\underline{-0.328}$ \\
\hline \multicolumn{3}{|c|}{ Silver (33) } \\
\hline Lawn & $\underline{0.358}$ & -0.071 \\
\hline Herb & -0.188 & -0.04 \\
\hline Shrub & -0.033 & $\underline{0.325}$ \\
\hline Tree & 0.055 & $\underline{-0.482}$ \\
\hline \multicolumn{3}{|c|}{ Gold (55) } \\
\hline Lawn & -0.119 & 0.042 \\
\hline Herb & $\underline{0.284}$ & 0.066 \\
\hline Shrub & -0.143 & -0.016 \\
\hline Tree & 0.118 & -0.007 \\
\hline \multicolumn{3}{|c|}{ Platinum (13) } \\
\hline Lawn & $\underline{-0.377}$ & 0.088 \\
\hline Herb & -0.003 & -0.176 \\
\hline Shrub & $\underline{0.393}$ & -0.211 \\
\hline Tree & $\underline{0.235}$ & -0.121 \\
\hline \multicolumn{3}{|c|}{ All Sites (147) } \\
\hline Lawn & -0.176 & 0.192 \\
\hline Herb & 0.191 & -0.122 \\
\hline Shrub & 0.036 & -0.036 \\
\hline Tree & $\underline{0.241}$ & -0.253 \\
\hline
\end{tabular}




\section{Chapter 2 References}

Aronson, Myla F. J., Frank A. La Sorte, Charles H. Nilon, Madhusudan Katti, Mark A. Goddard, Christopher A. Lepczyk, Paige S. Warren, et al. 2014. "A Global Analysis of the Impacts of Urbanization on Bird and Plant Diversity Reveals Key Anthropogenic Drivers." Proc. R. Soc. B 281 (1780): 20133330. https://doi.org/10.1098/rspb.2013.3330.

Audubon Society of Atlanta (AAS). 2017. "Wildlife Sanctuary Certification Program." https://www.atlantaaudubon.org/backyard-wildlife-sanctuary-certify.

Audubon Society of Portland. 2017. "Backyard Habitat Certification Program." https://www.facebook.com/BackyardHabitatCertification/.

Audubon Society of Portland. 2016. "Backyard Habitats." https://backyardhabitats.org/.

Audubon Society of Tucson (AST). 2017. "Habitat at Home: Backyard Habitat Recognition Program." http://www.tucsonaudubon.org/what-wedo/urban/homehabitat.html.

Bedan, Erik S., and John C. Clausen. 2009. "Storm water Runoff Quality and Quantity From Traditional and Low Impact Development Watersheds1." JAWRA Journal of the American Water Resources Association 45 (4):998-1008. https://doi.org/10.1111/j.1752-1688.2009.00342.x.

Belaire, J. Amy, Christopher J. Whelan, and Emily S. Minor. 2014. "Having Our Yards and Sharing Them Too: The Collective Effects of Yards on Native Bird Species in an Urban Landscape." Ecological Applications 24 (8):2132-43. https://doi.org/10.1890/13-2259.1.

Bergner, Adam, Mustafa Avcı, Hasan Eryiğit, Nicklas Jansson, Mats Niklasson, Lars Westerberg, and Per Milberg. 2015. "Influences of Forest Type and Habitat Structure on Bird Assemblages of Oak (Quercus Spp.) and Pine (Pinus Spp.) Stands in Southwestern Turkey." Forest Ecology and Management 336 (January):137-47. https://doi.org/10.1016/i.foreco.2014.10.025.

Beumer, Carijn, and Pim Martens. 2015. "Biodiversity in My (Back)Yard: Towards a Framework for Citizen Engagement in Exploring Biodiversity and Ecosystem Services in Residential Gardens." Sustainability Science 10 (1):87-100. https://doi.org/10.1007/s11625-014-0270-8. 
Biamonte, Estaban, Luis Sandoval, Eduardo Chacón, and Gilbert Barrantes. 2011. "Effect of Urbanization on the Avifauna in a Tropical Metropolitan Area." Landscape Ecology 26 (2): 183-94. https://doi.org/10.1007/s10980-010-9564-0

Blanco-Canqui, Humberto, C. J. Gantzer, S. H. Anderson, E. E. Alberts, and A. L. Thompson. 2004. "Grass Barrier and Vegetative Filter Strip Effectiveness in Reducing Runoff, Sediment, Nitrogen, and Phosphorus Loss." Soil Science Society of America Journal 68 (5): 1670-78. https://doi.org/10.2136/sssaj2004.1670.

Blair, Robert B. 1996. "Land Use and Avian Species Diversity Along an Urban Gradient." Ecological Applications 6 (2):506-19. https://doi.org/10.2307/2269387.

Boone, Christopher G., Mary L. Cadenasso, J. Morgan Grove, Kirsten Schwarz, and Geoffrey L. Buckley. 2010. "Landscape, Vegetation Characteristics, and Group Identity in an Urban and Suburban Watershed: Why the 60s Matter." Urban Ecosystems 13 (3):255-71. https://doi.org/10.1007/s11252-009-0118-7.

Brown, Beverly J., Randall J. Mitchell, and Shirley A. Graham. 2002. "Competition for Pollination Between an Invasive Species (Purple Loosestrife) and a Native Congener." Ecology 83 (8):2328-36. https://doi.org/10.1890/00129658(2002)083[2328:CFPBAI]2.0.CO;2.

Burghardt, Karin T., Douglas W. Tallamy, and W. Gregory Shriver. 2009. "Impact of Native Plants on Bird and Butterfly Biodiversity in Suburban Landscapes." Conservation Biology 23 (1): 219-24. https://doi.org/10.1111/j.15231739.2008.01076.x.

Burghardt, Karin T., Douglas W. Tallamy, Christopher Philips, and Kimberley J. Shropshire. 2010. "Non-Native Plants Reduce Abundance, Richness, and Host Specialization in Lepidopteran Communities." Ecosphere 1 (5):1-22. https://doi.org/10.1890/ES10-00032.1.

Cerra, Joshua F., and Rhiannon Crain. 2016. "Urban Birds and Planting Design: Strategies for Incorporating Ecological Goals into Residential Landscapes." Urban Ecosystems 19 (4):1823-46. https://doi.org/10.1007/s11252-016-0570-0.

Chace, Jameson F., and John J. Walsh. 2006. "Urban Effects on Native Avifauna: A Review." Landscape and Urban Planning 74 (1):46-69. https://doi.org/10.1016/i.landurbplan.2004.08.007.

Chamberlain, D. E., A. R. Cannon, and M. P. Toms. 2004. "Associations of Garden Birds with Gradients in Garden Habitat and Local Habitat." Ecography 27 (5):589-600. https://doi.org/10.1111/i.0906-7590.2004.03984.x. 
Ciach, Michał, and Arkadiusz Fröhlich. 2016. "Habitat Type, Food Resources, Noise and Light Pollution Explain the Species Composition, Abundance and Stability of a Winter Bird Assemblage in an Urban Environment." Urban Ecosystems, November 1-13. https://doi.org/10.1007/s11252-016-0613-6.

Cleary, Gráinne P., Holly Parsons, Adrian Davis, Bill R. Coleman, Darryl N. Jones, Kelly K. Miller, and Michael A. Weston. 2016. "Avian Assemblages at Bird Baths: A Comparison of Urban and Rural Bird Baths in Australia." PLOS ONE 11 (3):e0150899. https://doi.org/10.1371/journal.pone.0150899.

Conway, Delores, Christina Q. Li, Jennifer Wolch, Christopher Kahle, and Michael Jerrett. 2010. "A Spatial Autocorrelation Approach for Examining the Effects of Urban Greenspace on Residential Property Values." The Journal of Real Estate Finance and Economics 41 (2): 150-69. https://doi.org/10.1007/s11146-008-9159-6.

Crooks, Kevin R., and Michael E. Soule. 1999. "Mesopredator Release and Avifaunal Extinctions in a Fragmented System." Nature; London 400 (6744): 563-66. http://dx.doi.org.proxy.lib.pdx.edu/10.1038/23028.

Crooks, Kevin R, Andrew V Suarez, and Douglas T Bolger. 2004. “Avian Assemblages along a Gradient of Urbanization in a Highly Fragmented Landscape." Biological Conservation 115 (3): 451-62. https://doi.org/10.1016/S0006-3207(03)00162-9.

Daniels, G. D., and J. B. Kirkpatrick. 2006. "Does Variation in Garden Characteristics Influence the Conservation of Birds in Suburbia?" Biological Conservation 133 (3):326-35. https://doi.org/10.1016/j.biocon.2006.06.011.

De Baets, S., J. Poesen, G. Gyssels, and A. Knapen. 2006. "Effects of Grass Roots on the Erodibility of Topsoils during Concentrated Flow." Geomorphology 76 (1): 54-67. https://doi.org/10.1016/i.geomorph.2005.10.002.

Delaware Nature Society. "Certified Wildlife Habitat." 2017. Accessed January 4. http://delawarenaturesociety.org/CertifiedWildlifeHabitat.

Dixon, P. Grady, and Thomas L. Mote. 2003. "Patterns and Causes of Atlanta's Urban Heat Island-Initiated Precipitation." Journal of Applied Meteorology 42 (9): 127384. https://doi.org/10.1175/1520-0450(2003)042<1273:PACOAU>2.0.CO;2.

Duncan, Richard P., Steven E. Clemants, Richard T. Corlett, Amy K. Hahs, Michael A. McCarthy, Mark J. McDonnell, Mark W. Schwartz, Ken Thompson, Peter A. Vesk, and Nicholas S. G. Williams. 2011. "Plant Traits and Extinction in Urban Areas: A Meta-Analysis of 11 Cities." Global Ecology and Biogeography 20 (4): 509-19. https://doi.org/10.1111/j.1466-8238.2010.00633.x. 
Fattorini, Simone. 2011. "Insect Extinction by Urbanization: A Long Term Study in Rome." Biological Conservation 144 (1): 370-75. https://doi.org/10.1016/i.biocon.2010.09.014.

Fiedler, A. K., and D. A. Landis. 2007. "Attractiveness of Michigan Native Plants to Arthropod Natural Enemies and Herbivores." Environmental Entomology 36 (4):751-65. https://doi.org/10.1093/ee/36.4.751.

Fischer, Jason D., Sarah H. Cleeton, Timothy P. Lyons, and James R. Miller. 2012. "Urbanization and the Predation Paradox: The Role of Trophic Dynamics in Structuring Vertebrate Communities." BioScience 62 (9):809-18. https://doi.org/10.1525/bio.2012.62.9.6.

Foley, Jonathan A., Ruth DeFries, Gregory P. Asner, Carol Barford, Gordon Bonan, Stephen R. Carpenter, F. Stuart Chapin, et al. 2005. "Global Consequences of Land Use." Science 309 (5734): 570-74. https://doi.org/10.1126/science.1111772.

French, K., R. Major, and K. Hely. 2005. "Use of Native and Exotic Garden Plants by Suburban Nectarivorous Birds." Biological Conservation 121 (4): 545-59. https://doi.org/10.1016/j.biocon.2004.06.004.

Gaire, R., C. Astley, M. K. Upadhyaya, D. R. Clements, and M. Bargen. 2015. "The Biology of Canadian Weeds. 154. Himalayan Blackberry." Canadian Journal of Plant Science 95 (3):557-70. https://doi.org/10.1139/CJPS-2014-402.

Gerber, Esther, Christine Krebs, Craig Murrell, Marco Moretti, Remy Rocklin, and Urs Schaffner. 2008. "Exotic Invasive Knotweeds (Fallopia Spp.) Negatively Affect Native Plant and Invertebrate Assemblages in European Riparian Habitats." Biological Conservation 141 (3):646-54. https://doi.org/10.1016/j.biocon.2007.12.009.

Gibbs, Andrew. 2018. Avian Community and Urban Habitat Analysis: Total Avian Abundance Species Richness and Species Diversity Decline with Increasing Urbanization in Portland Oregon. Portland State Universty.

Grimm, Nancy B., Stanley H. Faeth, Nancy E. Golubiewski, Charles L. Redman, Jianguo Wu, Xuemei Bai, and John M. Briggs. 2008. "Global Change and the Ecology of Cities." Science 319 (5864):756-60. https://doi.org/10.1126/science.1150195.

Goddard, Mark A., Andrew J. Dougill, and Tim G. Benton. 2010. "Scaling up from Gardens: Biodiversity Conservation in Urban Environments." Trends in Ecology \& Evolution 25 (2): 90-98. https://doi.org/10.1016/i.tree.2009.07.016. 
Haley, Melissa B., Dukes Michael D., and Miller Grady L. 2007. "Residential Irrigation Water Use in Central Florida." Journal of Irrigation and Drainage Engineering 133 (5): 427-34. https://doi.org/10.1061/(ASCE)0733-9437(2007)133:5(427).

Hope, Diane, Corinna Gries, Weixing Zhu, William F. Fagan, Charles L. Redman, Nancy B. Grimm, Amy L. Nelson, Chris Martin, and Ann Kinzig. 2003. "Socioeconomics Drive Urban Plant Diversity." Proceedings of the National Academy of Sciences 100 (15):8788-92. https://doi.org/10.1073/pnas.1537557100.

Hovick, Torre J, R. Dwayne Elmore, and Samuel D Fuhlendorf. 2014. "Structural Heterogeneity Increases Diversity of Non-Breeding Grassland Birds." Ecosphere 5 (5):1-13. https://doi.org/10.1890/ES14-00062.1.

Johnston López, Karina, Alberto Macías Duarte, and Reyna Amanda Castillo Gámez. 2015. "Urban birds in the Sonoran Desert: estimating population density from point counts." Huitzil. Revista Mexicana de Ornitología 16 (1). http://www.redalyc.org.proxy.lib.pdx.edu/resumen.oa?id=75633058007.

Jolliffe, Ian T., and Jorge Cadima. 2016. "Principal Component Analysis: A Review and Recent Developments." Philosophical Transactions. Series A, Mathematical, Physical, and Engineering Sciences 374 (2065). https://doi.org/10.1098/rsta.2015.0202.

Kalnay, Eugenia, and Ming Cai. 2003. "Impact of Urbanization and Land-Use Change on Climate." Nature 423 (6939): 528-31. https://doi.org/10.1038/nature01675.

Kaufman, Dennis A., and Norman R. Cloutier. 2006. "The Impact of Small Brownfields and Greenspaces on Residential Property Values." The Journal of Real Estate Finance and Economics 33 (1): 19-30.

Kinzig, Ann, Paige Warren, Chris Martin, Diane Hope, and Madhusudan Katti. 2005. "The Effects of Human Socioeconomic Status and Cultural Characteristics on Urban Patterns of Biodiversity." Ecology and Society 10 (1). https://doi.org/10.5751/ES01264-100123.

Kirkpatrick, J. B., G. D. Daniels, and T. Zagorski. 2007. "Explaining Variation in Front Gardens between Suburbs of Hobart, Tasmania, Australia." Landscape and Urban Planning 79 (3-4):314-22. https://doi.org/10.1016/j.landurbplan.2006.03.006.

Kong, Fanhua, Haiwei Yin, and Nobukazu Nakagoshi. 2007. "Using GIS and Landscape Metrics in the Hedonic Price Modeling of the Amenity Value of Urban Green Space: A Case Study in Jinan City, China." Landscape and Urban Planning 79 (3): 240-52. https://doi.org/10.1016/i.landurbplan.2006.02.013. 
Larson, Kelli L., David Casagrande, Sharon L. Harlan, and Scott T. Yabiku. 2009. "Residents' Yard Choices and Rationales in a Desert City: Social Priorities, Ecological Impacts, and Decision Tradeoffs." Environmental Management 44 (5):921. https://doi.org/10.1007/s00267-009-9353-1.

Lerman, Susannah B., and Paige S. Warren. 2011. "The Conservation Value of Residential Yards: Linking Birds and People." Ecological Applications 21 (4): 1327-39. https://doi.org/10.1890/10-0423.1.

Lindsey, Rebecca. 2005. "Looking for Lawns" Earth Observatory United States National Air and Space Administration. November 8, 2005. https://earthobservatory.nasa.gov/Features/Lawn/.

MacArthur, Robert H., and John W. MacArthur. 1961. "On bird species diversity." Ecology 42, no. 3 (1961): 594-598.

Manly, BFJ. 1994. Multivariate statistics: a primer. New York: CRC Press. 215.

Marzluff, John M. 2001. "Worldwide Urbanization and Its Effects on Birds." In Avian Ecology and Conservation in an Urbanizing World, 19-47. Springer, Boston, MA. https://doi.org/10.1007/978-1-4615-1531-9 2.

Mason, Evan, and Franco A. Montalto. 2015. "The Overlooked Role of New York City Urban Yards in Mitigating and Adapting to Climate Change." Local Environment 20 (12):1412-27. https://doi.org/10.1080/13549839.2014.907249.

McIntyre, N. E., J. Rango, W. F. Fagan, and S. H. Faeth. 2001. "Ground Arthropod Community Structure in a Heterogeneous Urban Environment." Landscape and Urban Planning 52 (4):257-74. https://doi.org/10.1016/S0169-2046(00)00122-5.

McShea, William J., John Pagels, John Orrock, Elizabeth Harper, and Kevin Koy. 2003. "Mesic Deciduous Forest as Patches of Small-Mammal Richness within an Appalachian Mountain Forest." Journal of Mammalogy 84 (2):627-43. https://doi.org/10.1644/15451542(2003)084andlt;0627:MDFAPOandgt;2.0.CO;2.

Menon, Manjula, Prashanthi Devi M, and Mohanraj Rangaswamy. 2016. "Avifaunal Richness and Abundance Along an Urban Rural Gradient with Emphasis on Vegetative and Anthropogenic Attributes in Tiruchirappalli, India." Landscape Research 41 (1):131-48. https://doi.org/10.1080/01426397.2014.910294. 
Melles, S.J., Susan M. Glenn, and Kathy Martin. 2003. “Urban Bird Diversity and Landscape Complexity: Species-Environment Associations Along a Multiscale Habitat Gradient." Conservation Ecology 7 (June). https://doi.org/10.5751/ES00478-070105.

Mills, G. Scott, John B. Dunning, and John M. Bates. 1991. "The Relationship between Breeding Bird Density and Vegetation Volume." The Wilson Bulletin 103 (3): 46879.

Minor, Emily S., and Dean L. Urban. 2008. "A Graph-Theory Framework for Evaluating Landscape Connectivity and Conservation Planning." Conservation Biology 22 (2): 297-307. https://doi.org/10.1111/i.1523-1739.2007.00871.x.

Morton, T. G., A. J. Gold, and W. M. Sullivan. 1988. "Influence of Overwatering and Fertilization on Nitrogen Losses from Home Lawns." Journal of Environmental Quality 17 (1): 124-30. https://doi.org/10.2134/jeq1988.00472425001700010019x.

Müller, Norbert, Maria Ignatieva, Charles H. Nilon, Peter Werner, and Wayne C. Zipperer. 2013. "Patterns and Trends in Urban Biodiversity and Landscape Design." In Urbanization, Biodiversity and Ecosystem Services: Challenges and Opportunities, edited by Thomas Elmqvist, Michail Fragkias, Julie Goodness, Burak Güneralp, Peter J. Marcotullio, Robert I. McDonald, Susan Parnell, et al., 123-74. Springer Netherlands. https://doi.org/10.1007/978-94-007-7088-1 10.

Nassauer, Joan Iverson, Zhifang Wang, and Erik Dayrell. 2009. "What Will the Neighbors Think? Cultural Norms and Ecological Design." Landscape and Urban Planning 92 (3-4):282-92. https://doi.org/10.1016/i.landurbplan.2009.05.010.

National Wildlife Federation (NWF) 2017. "Garden for Wildlife" requirements. https://www.nwf.org/garden-for-wildlife.

Ortega-Álvarez, Rubén, and Ian MacGregor-Fors. 2009. "Living in the Big City: Effects of Urban Land-Use on Bird Community Structure, Diversity, and Composition." Landscape and Urban Planning 90 (3-4):189-95. https://doi.org/10.1016/j.landurbplan.2008.11.003.

OSU Extension Master Gardener Metro Area. 2017. “Master Gardener Program”. Oregon State University. Accessed December 15, 2017. http://extension.oregonstate.edu/mg/metro/2018-MG-Program. 
Palomino, David, and Luis M. Carrascal. 2006. "Urban Influence on Birds at a Regional Scale: A Case Study with the Avifauna of Northern Madrid Province." Landscape and Urban Planning 77 (3):276-90. https://doi.org/10.1016/i.landurbplan.2005.04.003.

Pataki, Diane E, Margaret M Carreiro, Jennifer Cherrier, Nancy E Grulke, Viniece Jennings, Stephanie Pincetl, Richard V Pouyat, Thomas H Whitlow, and Wayne C Zipperer. 2011. "Coupling Biogeochemical Cycles in Urban Environments: Ecosystem Services, Green Solutions, and Misconceptions." Frontiers in Ecology and the Environment 9 (1):27-36. https://doi.org/10.1890/090220.

Peters, Robert Henry. 1986. The Ecological Implications of Body Size. Cambridge University Press.

Philpott, Stacy M., Julie Cotton, Peter Bichier, Russell L. Friedrich, Leigh C. Moorhead, Shinsuke Uno, and Monica Valdez. 2014. "Local and Landscape Drivers of Arthropod Abundance, Richness, and Trophic Composition in Urban Habitats." Urban Ecosystems 17 (2):513-32. https://doi.org/10.1007/s11252-013-0333-0.

Pievani, Telmo. 2014. "The Sixth Mass Extinction: Anthropocene and the Human Impact on Biodiversity." Rendiconti Lincei 25 (1): 85-93. https://doi.org/10.1007/s12210013-0258-9.

Pidgeon, Anna M., Curtis H. Flather, Volker C. Radeloff, Christopher A. Lepczyk, Nicholas S. Keuler, Eric M. Wood, Susan I. Stewart, and Roger B. Hammer. 2014. "Systematic Temporal Patterns in the Relationship Between Housing Development and Forest Bird Biodiversity." Conservation Biology 28 (5):12911301. https://doi.org/10.1111/cobi.12291.

Politi Bertoncini, Alzira, Nathalie Machon, Sandrine Pavoine, and Audrey Muratet. 2012. "Local Gardening Practices Shape Urban Lawn Floristic Communities." Landscape and Urban Planning 105 (1): 53-61. https://doi.org/10.1016/i.landurbplan.2011.11.017.

Pope, C. Arden III, Majid Ezzati, and Douglas W. Dockery. 2009. "Fine-Particulate Air Pollution and Life Expectancy in the United States." New England Journal of Medicine 360 (4):376-86. https://doi.org/10.1056/NEJMsa0805646.

Portland Oregon Bureau of Planning and Sustainability. 2016. "Portland Plant List". https://www.portlandoregon.gov/citycode/article/322280

Portland Metro Regional Government. 2014. "Canopy 2014". http://rlisdiscovery.oregonmetro.gov/?resourcelD=99. 
Proença, Vânia M., Henrique M. Pereira, João Guilherme, and Luís Vicente. 2010. “Plant and Bird Diversity in Natural Forests and in Native and Exotic Plantations in NW Portugal." Acta Oecologica 36 (2): 219-26. https://doi.org/10.1016/i.actao.2010.01.002.

Robel, R. J., J. N. Briggs, A. D. Dayton, and L. C. Hulbert. 1970. "Relationships between Visual Obstruction Measurements and Weight of Grassland Vegetation." Journal of Range Management 23 (4):295-97. https://doi.org/10.2307/3896225.

Rodewald, P. (Editor). 2015. The Birds of North America: https://birdsna.org. Cornell Laboratory of Ornithology, Ithaca, NY.

Rodriguez, Shari L., M. Nils Peterson, and Christopher J. Moorman. 2016. “Does Education Influence Wildlife Friendly Landscaping Preferences?" Urban Ecosystems, November, 1-8. https://doi.org/10.1007/s11252-016-0609-2.

Rudd, Hillary, Jamie Vala, and Valentin Schaefer. 2002. "Importance of Backyard Habitat in a Comprehensive Biodiversity Conservation Strategy: A Connectivity Analysis of Urban Green Spaces." Restoration Ecology 10 (2): 368-75. https://doi.org/10.1046/i.1526-100X.2002.02041.x.

San Jose, California, Guadalupe River Park Conservancy. "Green Gardens, Healthy Creeks". 2017. https://www.sanjoseca.gov/DocumentCenter/View/15345.

Sattler, T., P. Duelli, M. K. Obrist, R. Arlettaz, and M. Moretti. 2010. “Response of Arthropod Species Richness and Functional Groups to Urban Habitat Structure and Management." Landscape Ecology 25 (6):941-54. https://doi.org/10.1007/s10980-010-9473-2.

Schmidt, Kenneth A., and Christopher J. Whelan. 1999. "Effects of Exotic Lonicera and Rhamnus on Songbird Nest Predation." Conservation Biology 13 (6):1502-6. https://doi.org/10.1046/i.1523-1739.1999.99050.x.

Sewell, Sarah, Dennis McCallister, Roch Gaussoin, and Charles Wortmann. "Lawn management practices and perceptions of residents in 14 sandpit lakes of Nebraska." J. Ext 48 (2010): 1-8.

Shipley, Amy A., Michael T. Murphy, and Adam H. Elzinga. 2013. "Residential Edges as Ecological Traps: Postfledging Survival of a Ground-Nesting Passerine in a Forested Urban Park." The Auk 130 (3): 501-11. https://doi.org/10.1525/auk.2013.12139. 
Smith, Lionel S., Moth E. J. Broyles, Helen K. Larzleer, and Mark D. E. Fellowes. 2015. "Adding Ecological Value to the Urban Lawnscape. Insect Abundance and Diversity in Grass-Free Lawns." Biodiversity and Conservation 24 (1): 47-62. https://doi.org/10.1007/s10531-014-0788-1.

Stephens, Ryan B., and Eric M. Anderson. 2014. "Habitat Associations and Assemblages of Small Mammals in Natural Plant Communities of Wisconsin." Journal of Mammalogy 95 (2):404-20. https://doi.org/10.1644/13-MAMM-A-025.

Strohbach, Michael W., Susannah B. Lerman, and Paige S. Warren. 2013. "Are Small Greening Areas Enhancing Bird Diversity? Insights from Community-Driven Greening Projects in Boston." Landscape and Urban Planning 114 (June):69-79. https://doi.org/10.1016/i.landurbplan.2013.02.007.

Tallamy, Douglas W., and Kimberley J. Shropshire. 2009. "Ranking Lepidopteran Use of Native Versus Introduced Plants." Conservation Biology 23 (4):941-47. https://doi.org/10.1111/i.1523-1739.2009.01202.x.

Thomas, J. A., M. G. Telfer, D. B. Roy, C. D. Preston, J. J. D. Greenwood, J. Asher, R. Fox, R. T. Clarke, and J. H. Lawton. 2004. "Comparative Losses of British Butterflies, Birds, and Plants and the Global Extinction Crisis." Science 303 (5665): 1879-81. https://doi.org/10.1126/science.1095046.

Thompson, Ken, John G. Hodgson, Richard M. Smith, Philip H. Warren, Kevin J. Gaston, and J. P. Bakker. 2004. "Urban Domestic Gardens (III): Composition and Diversity of Lawn Floras." Journal of Vegetation Science 15 (3): 373-78. https://doi.org/10.1658/1100-9233(2004)015[0373:UDGICA]2.0.CO;2.

Trollope, Samuel T., John G. White, and Raylene Cooke. 2009. "The Response of Ground and Bark Foraging Insectivorous Birds across an Urban-forest Gradient." Landscape and Urban Planning 93 (2): 142-50. https://doi.org/10.1016/j.landurbplan.2009.06.013.

Troy, Austin R., J. Morgan Grove, Jarlath P. M. O'Neil-Dunne, Steward T. A. Pickett, and Mary L. Cadenasso. 2007. "Predicting Opportunities for Greening and Patterns of Vegetation on Private Urban Lands." Environmental Management 40 (3):394412. https://doi.org/10.1007/s00267-006-0112-2.

Tyrväinen, Liisa, and Antti Miettinen. 2000. "Property Prices and Urban Forest Amenities." Journal of Environmental Economics and Management 39 (2): 20523. https://doi.org/10.1006/jeem.1999.1097. 
United Nations. 2017. "World Population Prospects: The 2017 Revision Multimedia Library United Nations Department of Economic and Social Affairs." Accessed February 9, 2018. https://www.un.org/development/desa/publications/worldpopulation-prospects-the-2017-revision.html.

United States Environmental Protection Agency. 2015. "EnviroAtlas Community Data." ftp://newftp.epa.gov/epadatacommons/ORD/EnviroAtlas/POR Landcover tif.zip

United States Environmental Protection Agency. 2016. "Integrated Pest Management". https://www.epa.gov/managing-pests-schools/introduction-integrated-pest$\underline{\text { management }}$

Violin, Christy R., Peter Cada, Elizabeth B. Sudduth, Brooke A. Hassett, David L. Penrose, and Emily S. Bernhardt. 2011. "Effects of Urbanization and Urban Stream Restoration on the Physical and Biological Structure of Stream Ecosystems." Ecological Applications 21 (6): 1932-49. https://doi.org/10.1890/10-1551.1.

West, Nikkie Audubon Society of Portland. Electronic written personal communication (e-mail). 2013.

West, Nikkie. Audubon Society of Portend, Backyard Habitat Certification Program, Metro Resource Conservation and Recycling, Final FY15-16 report. 2016.

Wheeler, Andrew P., Paul L. Angermeier, and Amanda E. Rosenberger. 2005. "Impacts of New Highways and Subsequent Landscape Urbanization on Stream Habitat and Biota." Reviews in Fisheries Science 13 (3): 141-64. https://doi.org/10.1080/10641260590964449.

White, John G., Mark J. Antos, James A. Fitzsimons, and Grant C. Palmer. 2005. “NonUniform Bird Assemblages in Urban Environments: The Influence of Streetscape Vegetation." Landscape and Urban Planning 71 (2-4):123-35. https://doi.org/10.1016/i.landurbplan.2004.02.006.

"Wildlife Sanctuary Certification Program | Atlanta Audubon Society." n.d. Accessed January 5, 2017. https://www.atlantaaudubon.org/backyard-wildlife-sanctuarycertify.

Yufen, Ren, Wang Xiaoke, Ouyang Zhiyun, Zheng Hua, Duan Xiaonan, and Miao Hong. 2008. "Stormwater Runoff Quality from Different Surfaces in an Urban Catchment in Beijing, China." Water Environment Research 80 (8):719-24. https://doi.org/10.2175/106143008X276660. 
Zmyslony, Jean, and Daniel Gagnon. 1998. "Residential Management of Urban FrontYard Landscape: A Random Process?" Landscape and Urban Planning 40 (4):295307. https://doi.org/10.1016/S0169-2046(97)00090-X. 


\title{
Chapter 3
}

The Ability of the Backyard Habitat Certification Program, Certified Habitat Yards, to Support the Avian Community of Portland Oregon.

\author{
Andrew Gibbs
}

\section{Abstract}

The Backyard Habitat Certification Program (BHCP) is a large yard habitat restoration program, encompassing over 3000 yards, certified at 3 levels: silver (SC), gold (GD) and platinum (PT). I tested the value of these yards and not-certified (NC) yards to birds by examining relationships among habitat variables at two landscape levels (150 m and 500 m from each yard) and using within-yard vegetation measurements. I conducted 3 - 4 bird surveys in 146 yards over 2 summers. These yards were also surveyed for vegetation once over the same period. Bird surveys were 10 minute counts, yard vegetation percent cover was collected with quadrats, while landscape variables were extracted from LIDAR and aerial photographs. Avian abundance, and richness and diversity of bird species were found to respond to principal component axes of urbanization, and variables related to urbanization (e.g., impervious surface, canopy cover, and population density), to the yard variables of planted area and mulch and slightly to certification level. Individual species generally responded in groups; urban avoiding, preferring, or ambivalent. Increasing vegetation of all types, reducing 
disturbance and reducing mulching were found to contribute towards greater numbers of birds. Restored yards in poorer quality matrix likely have less value than restored yards in higher quality matrix, while yards near natural areas, especially/or in groups, may be of greater individual value than more isolated yards. 


\section{Introduction}

Cities are largely inimical to the existence of wildlife, but with restoration efforts, we may be able to restore former degraded natural areas to habitable space for wildlife (Wortley et al. 2013). Large scale restoration can provide critical resources such as food along migratory routes and breeding habitat (Ruiz-Jaén and Aide 2005, Martin et al. 2005), but measuring successful restoration is difficult (Longcore 2003), and restoration may include only partial return of a full community of organisms (Andersen 1993, Lomov et al. 2009). Restoration efforts can be slowed by re-invasion of exotic weeds that prevent reproduction of native plants (Wallace et al. 2017). Furthermore, without consideration of pre-restoration conditions it may be impossible to ascertain the value of any restoration effort (Hobbs and Norton 1996).

Public efforts to restore and preserve biodiversity in cities are focused primarily on parcels of land under municipal control, and many of these efforts tend to be located on the edges of cities and isolated from each other (Oh and Jeong 2007). However suitable parcels of habitat within cities can support many avian species (Sandström et al. 2006), including both resident and migrant species (Carbó-Ramírez and Zuria 2011). That said, it is also true that urban food webs are often incomplete because intensely urbanized areas often tend to have low diversity and abundance of invertebrates (Jones and Leather 2012), and consequently, secondary consumers such as birds (Chace and Walsh 2006, Palomino and Carrascal 2006). Not surprisingly, therefore, less developed suburban areas often support more diverse communities of birds (Blair 2004), which 
may be enhanced by vegetation that matches the native habitat (Marzluff and Ewing 2001, Lerman and Warren 2011).

However, no matter how well a city manages its own land, much of the space in every city is residential and privately owned. The city of Portland, Oregon, for instance, maintains heavily treed greenways designed to limit automobile access and to promote bicycle use (Portland 2016 1). The city government has established tree cover minimums, and plans future increases (Portland 2007). In addition to managing the urban landscape for tree cover, Portland contains Forest Park, the largest urban forest in the United States (2,025 ha), and dozens of smaller natural areas dispersed across the city. The expanse of houses and yards separating the natural areas are a logical target for restoration as the landscaping of most urban areas provide few if any resources for wildlife (Bormann et al. 2001, Marzluff and Ewing 2001).

As in other cities, Portland's landscape has been gradually deforested and urbanized, but fortunately, large parcels of undeveloped land have been maintained or restored. Nonetheless, variation across the city in housing density creates a heterogenous landscape with blocks of highly urbanized areas next to blocks of single family homes. Forest Park and other natural areas contain mostly second growth forest, but some old growth forest patches remain, and this is important because these islands of habitat can support sensitive and migrant species (Hennings and Edge 2003). The problem, however, is that they are isolated from each other by the extensive urban matrix. While greenways along streets may create potential wildlife corridors, well 
established yard habitats throughout the city may be able to create buffers around natural areas and provide connectivity between them.

Indeed, evidence is growing that adding native plants to yard vegetation enhances diversity of avian communities (Burghardt et al. 2009, Goddard et al. 2010, and Lerman and Warren 2011). For instance, Daniels and Kirkpatrick (2006) found that some bird species show plant species preference (not always native) and concluded that yards can be an important contributor to avian conservation. Heezik and Adams (2016) also found that housing density and garden characteristics impacted avian community structure. Evidence is still meager, however, and what is now needed is more intensive studies of bird and plant community structure in yards to address the important question of whether individual efforts to enhance wildlife populations through native plantings can succeed in enhancing wildlife populations. The idea that yards can be planted in a way to provide at least some habitat for birds, or other wildlife, is supported by work in urban environments that show variables such as canopy cover, lawn and impervious surface in small regions do affect avian community structure. For example, Melles et al. (2003) found that presence of trees and fruiting shrubs increased bird abundance on both local and regional scales (within 1,000 m of sample points) whereas abundance declined with increasing cover by impervious surfaces.

In this study, I tested the hypothesis that avian abundance, richness, and diversity in yards could all be enhanced by modification of local (yard) habitat. In addition, I examine the responses of individual species to variation in yard habitat structure. I used data on vegetation structure and avian community structure from 146 
yards in the Audubon Society of Portland (ASP) Backyard Habitat Certification Program (BHCP), and other yards not in the program, along with GIS based landscape data, to measure avian responses to vegetation characteristics at both the local (the yard) and larger landscape scale. My sample thus included yards that ran the gamut from very traditional lawn centered landscape design to yards restored and 'certified' by BHCP as highly suitable bird habitat (Gibbs 2018 1). As of 2016 the BHCP involves 3,500 yards (West 2016) distributed across the city; this number increases annually by 300 to 500 yards. I described the program in (Gibbs 2018 1), and have found that certified yards, while varying in structure on a continuum, are on average distinguishable based on representation of native plants and vegetation structure.

The BHCP was initiated by citizens in Portland who developed the program for certifying yards as free of invasive species of plants, and with a minimum level of native plants and multiple levels of vegetation structure. A primary goal was to enhance wildlife habitat, but the program relies on anecdotal reports from participants to support its claims of success in creating bird habitat. Mine is an independent study of the impact of overt changes to these yards to enhance bird species richness. However, it is also important to question whether efforts at the scale of individual lawns can override landscape scale effects, and therefore I also attempted to understand how species distribution patterns in yards are influenced by the landscape within which yards are embedded. I provide a critical evaluation of the program, its success, its limitations, and make recommendations for this and other yard restoration programs. 


\section{Methods}

\section{Description of the city, site selection, BHCP}

This study was conducted within the boundaries of privately owned yards located in Portland, Oregon $\left(45.52^{\circ} \mathrm{N}, 122.67^{\circ} \mathrm{W}\right)$, a city of 639,863 people living within a $375 \mathrm{~km}^{2}$ area (US Census Bureau 2017). The surrounding suburban areas include another 1.5 million people and were partially included in the study area (Figure 3.1). Portland's Pacific Northwest climate is cool (near freezing) and wet in winter, warm ( $\left.35^{\circ} \mathrm{C}\right)$ and dry in summer, and with an average annual total precipitation of $100 \mathrm{~cm}$. Portland's natural vegetation is conifer-dominated forests, most of which is currently found scattered in residential neighborhoods and parks and greenspaces (P\&GSs) throughout the city.

Selection of yards in this study was a tiered process beginning with choosing regions with appropriate tree cover, and then selecting yards within these regions. Two neighborhoods with high canopy cover levels (70-80\%) and two with low levels (0-30\%) were chosen via visual inspection of aerial photographs. All BHCP participants in the selected neighborhoods were contacted by ASP about the study via an email describing my study. Those interested contacted me and volunteered their yards. I also wanted to have traditional landscaping represented in my sample and to recruit these and other non-certified yards, contacts were made with people at neighborhood association meetings, events that I sponsored in participant's yards, and through direct recruitment of neighbors. Over 500 people offered their yards. I randomly ordered the sites in each 
neighborhood so as not to bias any yards. I sampled 200 yards adequately in a single season for birds, and 151 of these were selected randomly (random number generation in Microsoft Excel 2007) for vegetation surveys. Several of the 151 were excluded from final analysis because less than three bird surveys were conducted, or they were too large to be comparable, leading to 146 yards.

\section{Field methods}

Yards in the study were not visited prior to the first bird survey, as they were often recruited and surveyed initially in the same week. Initial site visits included brief notes ( $\sim \mathrm{min}$ ) about the vegetation composition including rough coverage estimates of herbs, shrubs, and trees, and rapid sets of photographs of each yard that were later used to verify vegetation measurements by roughly confirming the later measurements of vegetation cover. To maintain random choice of yards, no yards were rejected based on any initial vegetation findings; any yard that was volunteered in the proper neighborhoods was included in the study. Yards in this study were surveyed for birds in conjunction with a concurrent study of avian distributions across the Portland landscape (Gibbs 2018 2). All but three of the 146 participating yards were associated with singlefamily dwellings, and while the configuration of yards varied (i.e., position of house in yard), most had traditional front and backyards.

Bird surveys were conducted in the early mornings of 2013 (5 June through 24 July) and 2014 (25 May to 21 August). Each day between 8 and 16 points, including yards and landscape points, were surveyed. I conducted all bird surveys, and 711 of the 
967 were in yards. Yards were surveyed exclusively on week days (Monday-Friday) to limit encounters with residents. Points were reached by car, and routes were rotated to ensure all regions of the city were sampled throughout the weeks of both summers. I used a modified variable circular plot method (Reynolds et al. 1980) for 10-min point counts that I divided into five 2-min segments. On approach to each backyard, species encountered in the front (street side) of a house were noted but were only included in the official count on the rare occasions ( $1 \%$ of 711 surveys) when the same species was/were not detected during the 10-min count. Each yard was entered as quietly as possible, and I occupied a location giving a clear but inconspicuous view of as much of the yard as possible. I then waited two minutes before beginning a count. All individuals detected by sight or sound within the survey period were counted, taking care to not count the same individual twice. Individuals using bird feeders were counted, and this behavior was noted. Flyovers were not included in the analyses.

As sound level makes detecting birds difficult, and may impact their behavior (Brumm 2004, Parris and Schneider 2009, Halfwerk et al. 2011), level of background noise was estimated as very low, low, moderate, or high. If sound level changed during a survey it was noted. Very low sound is rare, exists primarily in wild areas, but rarely in the city. Low is the normal background hum of the city, where auditory detection of species at significant distance (at least $150 \mathrm{~m}$ ) is still possible. Moderate sound level indicated a point source of sound that limited distant detection of birds for at least a minute and up to 3 minutes but did not reduce detectability within $50 \mathrm{~m}$. High sound level was defined as greatly reduced detectability at any distance; tools such as leaf 
blowers, garbage trucks, and construction equipment created this kind of noise level. If such levels of sound occurred during a survey it was discontinued until the noise ended or I repeated the survey on a different day. Surveys were not conducted if it was raining more than a slight mist, which meant that I occasionally waited 10-min to initiate counts after the end of rain.

Data from all surveys for each yard were summarized into single mean values of avian abundance (total number of birds per survey), species richness (number of species per survey) and avian diversity (Shannon-Wiener index). Furthermore, encounter rate (fraction of surveys containing a species) was calculated for all species at each location.

\section{Vegetation Surveys}

To characterize urban habitat, I used data from two public sources describing tree canopy cover, land cover, and number of people to quantify regional landscape around each yard. As described previously (Gibbs 2018 2), I used ArcGIS 10.2 to process all spatial data. The "Buffer" tool was used to create $150 \mathrm{~m}$ (local), $500 \mathrm{~m}$ (landscape), and $30 \mathrm{~m}$ (yard) radius buffers (circles) around each yard to test for associations of birds with landscape features at local and larger landscape scales. Tree canopy cover values for each buffer distance were from a raster file developed from LIDAR data (Portland Metro 2014) while a raster file from the US EPA Enviro-Atlas (US EPA 2015) contained values for landscape cover types including impervious surface, soil or bare ground, tree or forest, grass and herbaceous, woody wetlands, and emergent wetlands. Tree or forest and grass/herbaceous were summed to create a new variable called Total Green. 
Census block data from Portland Metro (Portland Metro 2014) were used to create a population density raster file. The variables were added to the $150 \mathrm{~m}$ and $500 \mathrm{~m}$ circles. To test the strength of the association between my assessment of canopy cover from my field samples and the independent LIDAR data, I compared LIDAR tree cover from the $30 \mathrm{~m}$ radius buffers to my yard-based measures.

The BHCP certifies 3 levels of yard restoration, increasing in number of requirements and level of vegetation cover from silver (SV) to gold (GD) and then platinum (PT) level yards (Appendix C Table 1) which I determined are distinct from each other (Figure 3.2) (Gibbs 2018 1). Requirements for vegetation have minimum criteria for percentage of plantable areas occupied by native plants: $5.0 \%$ for SV, $15.0 \%$ for GD, and $50.0 \%$ for PT. All yards are expected to have multiple vegetation levels such as tree canopy, and understory canopy increasing from three levels for SV, four for GD and five for PT (Appendix C Table 1).

Yard vegetation surveys took 2 to 6 hours each to complete. I conducted them during the afternoons after bird surveys in 2013 and 2014 or in the later summer when bird surveys were complete; in 2015 surveys were conducted throughout the study period. I surveyed between 2 and 4 yards each day until the end of the season, which was determined by early leaf fall. For all measurements, a $1 \mathrm{~m}^{2}$ square quadrat was used to sample from 3-16 locations in each yard, the number being determined by yard plantable area. For smaller yards $\left(\leq 533 \mathrm{~m}^{2}\right) 3 \%$ of the area of yards was sampled; for larger yards $\left(534-1600 \mathrm{~m}^{2}\right)$ between $3 \%$ and $1 \%$ was sampled. Yards larger than $1600 \mathrm{~m}^{2}$ were not included. To select random locations, plantable yard length and width were 
used as $\mathrm{X}-\mathrm{Y}$ axes and the yard then gridded at $1 \mathrm{~m}$ intervals. Coordinates for each quadrat location were then chosen by using a random number generating application. For each quadrat sample, I estimated the proportion of the $1 \mathrm{~m}^{2}$ area that was covered by lawn, stone, mulch, fine litter, or bare ground. The quadrat was subdivided creating 16 smaller squares to improve accuracy of my estimates. I used the quadrat and a pole marked with $10 \mathrm{~cm}$ long white stripes at $0.5 \mathrm{~m}, 1.0 \mathrm{~m}$, and $1.5 \mathrm{~m}$ to estimate the percent cover of native, exotic, and total herbaceous plants, shrubs, and tree vegetation at ground level and at each of the 3 marked heights above each quadrat. To make above ground measurements I used a flat piece of wood (my clipboard) held at each height in sequence from $0.5 \mathrm{~m}$ to $1.5 \mathrm{~m}$ and looking from above estimated the percent cover of each variable. For tree canopy, and shrubs taller than $1.5 \mathrm{~m}$, I looked up from the corners of each quadrat, and estimated percent cover above $1.5 \mathrm{~m}$. I totaled the measurements into a single value per quadrat for each variable. The vegetation height pole doubled as a Robel pole-like (Robel 1970) device that I used to measure vertical obstruction by estimating the percentage of obstruction at the $10 \mathrm{~cm}$ light colored regions. To do this I moved $4 \mathrm{~m}$ away from the pole in a random direction that was determined by spinning a $10 \mathrm{~cm}$ pointed metal device rapidly and allowing it to fall to the ground indicating a direction. Attached to the $1.0 \mathrm{~m}$ mark on the pole was a $4 \mathrm{~m}$ rope. I extended the rope in the direction indicated by the pointer and stood facing the pole at the end of the rope. I estimated the level of obstruction by plants at each of the three above-ground heights, and later combined these into a single total for each quadrat. All samples for each yard were pooled into single averages for each variable; 
fine litter, lawn, mulch, total shrub, total herb, total tree, vertical obstruction and native and exotic totals for herb $(\mathrm{H})$, shrub $(\mathrm{S})$, and trees $(\mathrm{T})$.

\section{Statistical Analysis}

The significant habitat differences that exist among BHCP yard certification levels (Gibbs 2018 1) justified using yard certification as a potential predictor of avian distribution. I used analysis of variance to compare mean values of abundance, richness, and diversity among the three certification levels and non-certified yards. All ANOVA were performed with and without the non-certified yards in the analysis.

My attempts to identify the determinants of avian community structure of yards involved predictor variables measured within yards and the landscape matrix. Landscape variables at $150 \mathrm{~m}$ and $500 \mathrm{~m}$ were used separately in two principal component analyses (PCA), and the first 3 eigenvectors of each were retained for use in other tests. A PCA for the yard variables ignored the native/non-native dichotomy and included the proportion covered by lawn, mulch, total herbaceous plants, total shrub, total tree, and bare ground. Correlation analysis was used to test for significant associations $(p<0.05)$ between avian abundance, richness and diversity and the full set of habitat variables, including eigenvectors from yard and landscape PCA's. Other yard level variables were total tree, exotic $\mathrm{H} / \mathrm{S} / \mathrm{T}$, native $\mathrm{H} / \mathrm{S} / \mathrm{T}$, stone, stump, 30 m canopy (LIDAR), and vertical obstruction. Landscape variables included in the PCA were mean human population density, and proportion of the area covered by impervious surface, soil or bare ground, grass and herbaceous plants, water, woody wetlands, emergent 
wetlands, and total green space. Variables that correlated significantly $(p<0.05)$ with response variables were retained for further evaluation in models for each response variable. Using the retained variables, I used a best subsets regression analysis to find top models among each group of variables (yard, $150 \mathrm{~m}$, and $500 \mathrm{~m}$ ) and then combined these models to find the set of best models for each response variable. To perform best subsets regression analysis, I used the stepwise function in JMP, which combines all variables in every possible combination. The maximum number of variables I allowed per model was 4. The top model (lowest AICC) from each separate analysis and all models within $2 \mathrm{AICC}$ of the top were retained as potentially competitive. Variables at the $150 \mathrm{~m}$ and $500 \mathrm{~m}$ landscape level that were retained by this method were then combined with retained yard variables to determine if models considering both landscape level and yard level habitat were competitive, and to determine the top set of models.

Summary variables such as abundance, richness, and species diversity are ultimately driven by the responses of individual species. It is thus critical to understand the response of individual species to the habitat variables. To determine the response of each species to habitat variables I examined encounter rate (proportion of surveys at each yard in which a species occurred) in relation to all yard and landscape variables, as well as the top eigenvectors from the PCAs of yard and habitat variables. Predictor variables that correlated significantly with at least one species were retained. 
I used JMP Pro 13 for all analysis. Statistics are given as mean $\pm S E, n$, and I considered results with $P \leq 0.05,0.10 \geq P>0.05$, and $P>0.10$ to be significant, marginally nonsignificant, and nonsignificant, respectively.

\section{Results}

I conducted 553 bird surveys in 146 yards with an average of 3.9 avian encounters per survey. Of the 146 sites 33 were SV, 54 were GD, 13 were PT, and 46 NC. There was a trend of increasing species richness among certification levels (Table 3.1), but regardless of whether NC yards (which exhibited comparatively high richness) were included, differences in richness among certification levels were not significant. Abundance followed the same general pattern as species richness (Table 3.1), and again, the differences among the yards were not significant. By contrast, without NC yards, species diversity increased with the certification levels (Table 3.1). However, this difference weakened when NC sites were included because species diversity of NC yards was intermediate to and overlapped SV and GD yards (Table 3.1).

Canopy cover in Portland rarely exceeded $70 \%$ cover (only 4 sites), and the overall mean was $35.7 \%$ at $150 \mathrm{~m}, 34.8 \%$ at $500 \mathrm{~m}$. Population density and the proportion of ground covered by impervious surface, grass/herbaceous and total green were distributed normally. Tree and forest cover (derived from aerial photographs) and the LIDAR canopy cover values were highly correlated (150 m: $r^{2}=0.94, p<0.0001 ; 500$ 
$m: r^{2}=0.97, p<0.0001$ ) and therefore for further analysis I used only the higher resolution LIDAR data. Woody wetlands and emergent wetlands did not occur within $500 \mathrm{~m}$ of any yard, and they were not considered further. The correlation coefficients between canopy cover, human population density, impervious surface, and total green measured at the local (150 $\mathrm{m}$ radius) and larger landscape (500 $\mathrm{m}$ radius) scales all exceeded $r=0.815(p<0.0001)$. Mean values for all four variables at the two spatial scales were also nearly identical. Grass and herbaceous plant cover exhibited a weaker $(r=0.723)$ but still highly significant correlation at the two spatial scales. By contrast, the ground surface covered by soil/bare ground and water, both of which were rare, and were unrelated within the local area and surrounding landscape (Table 3.2).

PCA of the variables at the local and landscape levels surrounding yards yielded axes of variation describing common urbanization trends. The first 3 eigenvectors explained $83.2 \%$ and $85.4 \%$ of the variation in landscape structure for the $150 \mathrm{~m}$ and $500 \mathrm{~m}$ buffers surrounding each yard, respectively. The first axis at the local $\left(\mathrm{PC}_{1} 150\right)$ and landscape level $\left(\mathrm{PC}_{1} 500\right)$ were essentially identical, contrasting sites with high canopy cover but low population density and little impervious surface (negative scores) with sites of low tree canopy but high population density and abundant impervious surface (positive scores) (Table 3.3). PC1 was thus a gradient of increasing urbanization. $\mathrm{PC}_{2} 150$ described a gradient of increasing soil or bare ground and grass/herbaceous cover. $\mathrm{PC}_{2} 500$ was similar to its local counterpart except that water (from the rivers) replaced grass/herbaceous. Eigenvalues for the third eigenvector at both the local and 
landscape scales did not exceed 1.0 and were therefore not interpreted or used in further analyses.

Yard variables showed weaker patterns of covariation than landscape variables. The first four eigenvectors of the yard PCA all had eigenvalues $\geq 1.0$ and accounted for just over $80 \%$ of the variation in yard habitat structure. While these components may not meet the criteria for further consideration (Jolliffe 2016), I describe them here, so others can look for the same (or different) patterns. $\mathrm{PC}_{1}$ yard was a contrast of yards that had few trees but abundant lawn (negative scores) with heavily treed yards with little lawn but abundant fine litter (positive scores; Table 3.3). $\mathrm{PC}_{1}$ yard was thus a gradient of traditional (mostly lawn) to non-traditional (high tree cover) yards. $\mathrm{PC}_{2}$ yard was similar to $\mathrm{PC}_{1}$ yard except that mulch replaced fine litter; it described a gradient of increasing tree cover and mulch but decreasing bare ground. $\mathrm{PC}_{3}$ yard described variation among yards in mainly lawn and herbaceous plant cover; yards with negative scores had abundant lawn and few herbaceous plants and little bare ground (negative scores) whereas positive scores were characteristic of yards with little lawn but abundant bare ground and herbaceous plant cover. Finally, $\mathrm{PC}_{4}$ yard was a contrast of yards with abundant herbaceous cover but few shrubs (negative scores) with yards dominated by shrubs and little herbaceous cover.

Correlation of abundance with all landscape and yard variables and eigenvectors from the three PCAs (24 correlations each) suggest that variation in abundance was independent of most yard variables, except that abundance increased with the area of yard that was planted and covered by fine litter but tended to be low where mulch 
cover was high (Table 3.4). Abundance was also independent of the LIDAR estimate of yard tree cover but varied positively with tree cover at the $150 \mathrm{~m}$ and $500 \mathrm{~m}$ landscape scales. Abundance declined with variables indicative of high urbanization at both landscape levels, but generally, negative correlations were stronger at the larger landscape scale (Table 3.4). Species richness and species diversity showed similar associations with yard and especially landscape variables. Richness and diversity both increased as area of the yard, herbaceous cover, native trees, fine litter, total planted area, and LIDAR estimates of yard tree cover increased (Table 3.4). Whether measured at the local or larger landscape level, richness and diversity increased with canopy cover and total greenspace in the landscape and declined as the landscape became increasingly urbanized (i.e., increasing population density, impervious surface, and PC1 at both scales). In nearly all cases, correlations of richness and diversity in yards with landscape variables were slightly stronger at the more local than larger landscape scales (Table 3.4). Correlations with yard principal components were weak and non-significant for $\mathrm{PC}_{1}$ yard and $\mathrm{PC}_{3}$ yard. However, abundance, richness and diversity were positively associated with increased $\mathrm{PC}_{2}$ yard, while abundance, richness and diversity all declined with increasing urbanization at the local $\left(\mathrm{PC1}_{150}\right)$ and landscape $\left(\mathrm{PC} 1_{500}\right)$ scales.

Best subsets regression analysis yielded only two competitive models for total abundance (Table 3.5). In both, roughly $30 \%$ of the variation in avian abundance was accounted for, and in both, abundance declined with increasing urbanization (positive $\mathrm{PC}_{1} 150$ scores) but increased with herbaceous yard cover and grass/herbaceous cover at the local scale. The top ranked model also suggested that abundance increased with 
area of the yard covered by exotic shrubs (Table 3.5). Analysis of species richness produced five competitive models (Table 3.6), and all accounted for $48-49 \%$ of variation in richness among yards. In all cases the two most influential associations were a decline in richness with increasing urbanization at the local level (i.e., $\mathrm{PC}_{1} 150$ ) and an increase in richness with plantable yard area (i.e., area not covered with impervious surface). Three additional variables all appeared in three models each; richness declined as (a) area of yard in mulch increased but increased as (b) grass/herbaceous in the surrounding $150 \mathrm{~m}$ buffer increased and (c) vertical habitat structure in yards (i.e., vertical obstruction) increased (Table 3.6). Five competitive models emerged from the analysis of species diversity and they all accounted for about $45 \%$ of the variation in species diversity among yards (Table 3.7). In all five, species diversity declined with increasing urbanization at the local level (i.e., $\mathrm{PC}_{1} 150$ ) but increased as the planted area of the yard expanded and as vertical structural diversity (i.e., vertical obstructions) increased. Four additional variables all appeared once but given the very modest increase in $R^{2}$ resulting from their inclusion (Table 3.7), their influence on species diversity was marginal.

I eliminated 19 of the 42 species detected in yards from analysis of encounter rate because they were encountered less than 3 times (all other species encountered $\geq 10$ times). In tables 3.8 and 3.9 I present correlations of each species encounter rate with the 19 yard/landscape variables that exhibited at least one significant $(P \leq 0.05)$ correlation with a species' encounter rate. Table 3.8 includes all predictor variables that $\geq$ seven species responded to, while Table 3.9 includes all predictor variables to which $\leq$ six species exhibited a response. Results of the analyses of encounter rate with $\mathrm{PC}_{1} 150$ 
$\mathrm{m}$ and $\mathrm{PC}_{1} 500 \mathrm{~m}$ are not presented in the Table 3.8 because they were identical to impervious surface (same sign) and canopy cover (opposite sign).

Of the 23 species, 11 exhibited significant negative responses of encounter rate with both cover by impervious surface and population density at the local scale. Most also exhibited significant increase in encounter rate as the planted area of yard increased (11 species), as tree canopy cover in the $30 \mathrm{~m}$ and $150 \mathrm{~m}$ area surrounding each yard increased ( 9 species for both), and as number of native trees in the yard increased (7 species). Most of these same species also exhibited negative responses to increases in grass/herbaceous cover at the larger landscape (7 species) and local (6 species) scales. In summary, these 11 species appear to be urban avoiders. Four other species exhibited an opposite set of associations and appear to be prefer urbanization. The California Scrub-Jay (all scientific names in Tables 3.8 and 3.9) is the only one of the four that is a native (Table 3.8), and all four tended to have high encounter rates at sites with abundant impervious surface and dense human populations at the local scale, and little tree cover at both the local scale and within yards (30 m buffer) (Table 3.8). Encounter rate of 3 of the 4 also increased as area of the local landscape covered by grass/herbaceous vegetation increased. Of the remaining eight species, only 4 of 72 possible correlations with yard or landscape variables were significant, suggesting the possibility that either data were insufficient to identify important habitat associations, or that they have distributions that are little influenced by the structure of urban landscapes. To test the former possibility, I compared encounter rate for species classified as urban avoiders, urban preferring, or urban tolerant species; no differences 
existed (ANOVA: $F=0.197, p=0.415$ ), suggesting that the species falling into the urban tolerant category were not insufficiently sampled. Encounter rate of the apparent urban avoiders also exhibited negative associations with area of yard covered by mulch (6 of 11) but positive relationship to area of yard covered by fine litter ( 4 of 11 species; Table 3.9). No more than 3 of 11 species exhibited significant associations with the other variables in Table 3.9. One of the four apparent urban preferring species, the European Starling, avoided areas of fine litter and herbaceous cover and was, by contrast, encountered frequently where lawn dominated yard surfaces. 


\section{Discussion}

The correlation analyses (Table 3.4) and best subsets regression analyses (Tables 3.5, 3.6, and 3.7) demonstrate clearly that birds in yards in Portland, OR, responded to variation in the city's landscape structure. Total avian abundance and species richness tended to, and species diversity clearly did, increase steadily within yards as the city landscape changed from large areas of impervious surface and high human population density to areas with dense tree canopy cover and lower housing density. However, the response of individual species to landscape variables differed considerably, as has been shown in previous work (Aldrich and Coffin 1980, Marzluff 2001, Chace and Walsh 2006, Ortega-Álvarez and MacGregor-Fors 2009). The impact of specific yard variables on abundance, species richness and species diversity appeared to be less important overall than landscape variables. Nonetheless, my results also identified several patterns indicating that modification of yards can affect avian community structure.

\section{Abundance, Richness and Diversity}

Response variables appeared to be affected relatively more by vegetation surrounding yards than by the yard variables. Species richness increased with increasing vertical structure within yards, but surprisingly, variables associated with three-dimensional structure (i.e., shrubs and herbs) had little influence on abundance and richness despite much research suggesting that vegetation structure is often correlated positively with higher abundance and richness (Mills et al. 1989, Evans et al. 2009; but see below). 
Encouraging results, however, were the trends for increasing abundance, richness, and diversity as yards progressed from SV to PT categories. However, species diversity was the only one to exhibit statistically significant change (Table 3.1), and then only when NC yards were excluded. That abundance and richness exhibited only weak trends with changes in yard structure likely reflects the complexities of the urban system and the generally continuous variation in habitat structure among certification levels. Overlap among the levels is expected, as advancement from one to the next is gradual. Homeowners may continue to improve their yards over time and the fact that recertification or upgrade of certification happens only once every 3 years may mean that some SV or GD yards may have supported more individuals/species because their official certification lagged behind the actual quality of vegetation present (Gibbs 2018 1).

Avian abundance, richness and diversity of the NC yards overlapped extensively with GD yards, and generally exceeded even SV yards in all measures of avian community health. This is possibly because most of the landowners of NC yards who chose to participate in the study were not a random sample of Portland landowners, as they were primarily contacted by those who have already certified yards. A preference for non-traditional yards is not uncommon in Portland, and it is possible that many NC yards were relatively natural and shaded toward wildlife-friendly. Because of strict application of criteria, a NC yard can be excluded from the BHCP because of the presence of a single invasive plant. Inclusion of more yards with primarily lawn cover may have led to greater discrimination of yard types. However, that NC yards always 
exhibited lower abundance, richness and diversity (albeit non-significantly) than PT yards suggests that the BHCP's succeeds in promoting the creation of high quality wildlife habitat, and that efforts by individual landowners to promote biotic diversity can succeed.

The correlations among diversity, richness, and to a lesser extent abundance show that yard habitat in Portland can have a measurable impact on birds. Total avian abundance did not respond strongly to yard habitat variables, except for fine litter (+), mulch (-), and planted area (+), which impact diversity and richness in the same manners. High levels of mulch seem to have a sterilizing effect for several years after application because mulch reduces arthropod abundance dramatically (Brown and Tworkoski 2004, Frank and Liburd 2005). Fine litter, which occurs in yards with trees and shrubs (see PC1 $1_{\text {Yard }}$ Table 3.3), has a positive effect on all three variables. Fine litter and decaying material, which is habitat for terrestrial arthropods, only exist in yards that have not been cleared with a leaf blower or other method. In addition to arthropods, litter attracts other invertebrates, native and exotic (such as worms and slugs), and contains seeds, all which are food for many bird species. Significant positive responses in richness and diversity to total herbaceous plant cover, native tree, and canopy cover in the $30 \mathrm{~m}$ buffer (Table 3.4) indicate that the BHCP requirements (Appendix C Table 1) for increases in herbaceous plant and tree canopy cover are important to birds. However, positive avian response to native trees was the only response to native plant variables I detected, indicating that the BHCP's requirements for native plants may not be having a measurable impact on birds, possibly because of the overwhelming limits 
set by other variables such as impervious surface, human population density, and canopy cover in the landscape.

Moreover, it is also possible that birds may be drawn to non-native plant species (Leston and Rodewald 2006) because of the abundant food and nest sites they provide. Reproduction in diverse urban systems may be equal to that in similar natural areas (Leston and Rodewald 2006). However, nest predation may be increased in exotic urban plantings (Rodewald et al. 2010), possibly due to poor branch structure and other features needed for safe nest sites (Schmidt and Whelan 1999). A second factor impacting this is the variety of landscape plants. In yards (usually PT) with extensive amounts of native plants, a common element was abundance of vegetation, but of a single dominant species of shrub (such as Oregon Grape) that covered much of the yard and created what was essentially a monoculture. Plant diversity and animal diversity are expected to be correlated (Tews et al. 2004) and this is likely the case in yards. Direct experimentation is required to settle this issue.

Correlation analysis produced results that add to and confirm current understandings of the underlying causes for variation of avian distributions in cities. Abundance, richness and diversity were all negatively associated with $\mathrm{PC}_{1} 150$, the primary axis describing increasing urbanization in this study. In Gibbs 20182 I show nonyard avian surveys yielded similar results. The positive contribution of vertical obstruction in all competitive models for diversity is the only indication I have that birds responded to shrub level vegetation. Shrubs are the primary contributor to vertical structure in a yard, and as such, they are an easy target to restore yards for wildlife. 
Shrubs are not the only contributor to vertical structure. Vertical obstruction can be viewed as the overall average volume of vegetation in a yard, and volume is strongly associated with avian abundance (Mills et al. 1991). It is likely that the combined effect of tall herbs and large shrubs in some yards create a more heterogeneous habitat and allow higher diversity by providing resources for more species (Tews et al. 2004). In addition, diverse urban habitat prevents gregarious (often invasive) species from congregating in large numbers (McClure 1989, Croci et al.2008).

My multivariate analyses showed that the landscape matrix outside of yards was the greatest contributor to variation in avian community structure in yards across the city. The urbanization gradient $\left(\mathrm{PC}_{150}\right)$ was most important, but at least some competitive models for abundance, richness and species diversity indicated that all three increased as grass and herbaceous plants within $150 \mathrm{~m}$ buffer surrounding each yard increased. The planted area of yards also explained much of the variation among yards in species richness and diversity. Thus, as with as larger natural areas (Gavareski 1976, Tilghman 1987, Davis and Brittingham 2004), yards with larger planted areas contain more species. This is an important finding and methods to create larger effective yards, such as the removal of barriers such as fences between yards (or use of less restrictive fencing), may create larger patches of habitat that are attractive to many ground foraging and nesting species.

The overriding importance of landscape variables for backyard bird communities is clear, but this should not dissuade individuals from restoring their yard as usable habitat. Rather, improvement of habitat within yards should be viewed as support for 
efforts to increase overall size of functional habitat, by grouping restored yards together. Through outreach, entire neighborhoods may be targeted for restoration so that region-wide programs can grow and elevate the quality of large areas. Focusing on neighborhoods near natural areas might be especially important because of the ability to expand the effective footprint of these areas through yard restoration (FernándezJuricic and Jokimäki 2001).

\section{Individual species responses}

Understanding the basis for variation in total abundance, species richness, and species diversity requires ultimately that we examine the responses of the individual species to urbanization and yard habitat structure. Here I focus on four species that cover the full response range from urban avoiding (Spotted Towhee) through urban tolerant (American Crow and Bushtit) to urban preferring (European Starling [Sturnus vulgaris]), and life history traits presumably important to their response to urbanization. The Spotted Towhee ("towhee") is a common species in wooded areas in Portland and symbolizes the struggle sensitive species face in cities. Towhees are active ground foraging and nesting birds. In this study, their responses to both yard and regional habitat were directly related to these two critical needs. As nonsocial territorial species, towhees, do not rely on conspecifics to alert them to predators, and must instead rely on being cryptic and elusive. These same traits, to one degree or another, also characterize the other 10 urbanization avoiders. Towhees, like other urbanization avoiders, eschewed areas of dense human populations, abundant impervious surface, 
large lawn areas (150 m and $500 \mathrm{~m}$ grass/herb), and yards with heavy mulch layers (Tables 3.8, 3.9). Towhee preference for areas of denser canopy cover, both within yards (30 $\mathrm{m}$ canopy) and at the local $(150 \mathrm{~m})$ landscape scale, likely occurred because trees are correlated with fine litter (this study), and fine litter is associated with high arthropod abundance (Braman et al. 2000). Towhees are thus linked to trees because of the foraging and nesting habitat trees create on the ground. While towhees no doubt avoid large areas of lawn because they are devoid of appropriate arthropod food (McIntyre et al. 2001, Faeth et al. 2011), lawns also expose them to predators of both adults and nests.

In contrast to the Spotted Towhee is the invasive European Starling ("starling"). I found that starlings were most frequently encountered in areas with abundant impervious surface and high human population density where grass, both in yards and at the $150 \mathrm{~m}$ scale, was abundant. Starlings appeared to avoid areas of high tree cover, and though starlings utilize trees for nesting and roosting, they forage in open spaces, often in large loose flocks that may assist in the early detection of predators (Sridhar et al. 2009). Like starlings, the other apparent urbanization preferring species (Table 3.8) tend to be gregarious in all seasons (although less so during the breeding season).

Eight of the species found in yards did not show strong responses to urbanization or structure of the yards themselves. Some of these, e.g. Lesser Goldfinch, are adapted to forest edge and unpredictable food sources, making them able to benefit from the dispersed islands of habitat in the city. This category of urban tolerant species is broad and at first glance they share few characteristics, as the Bushtit and American 
Crow ("crow") exemplify. Crows are generally the largest birds in the city, and Bushtits nearly the smallest. They are both social, a characteristic of all species in this group except Anna's Hummingbird (Calypte anna) and Brown Creepers (Certhia americana). Both crows and Bushtits utilize anthropogenic sources of food such as feeders, while crows can also feed from numerous other sources. Crows, Mourning Doves, and sometimes House Finches are ground foraging species. My concern that small sample size (few encounters) led to insufficient data to classify urban tolerant species as either avoiding or preferring appears unlikely, but further research may be needed for some species to better understand their habitat associations in the city (e.g. Brown Creeper). Understanding the individual species responses, and the life histories behind them, are both critical resources in the habitat restoration process and should always be considered. The decision to plant or remove a tree or place a feeder may or may not affect avian species diversity in a yard, but it will undoubtedly change the species that are present in a yard. Of further note is the absence of any migratory species among the 23 found in yards in this study. While migrant species are present in large natural areas in Portland (Hennings and Edge 2003), yards do not appear capable of providing the resources required by these species.

I close with my opinion and evaluation of the BHCP, and some data driven advice for small-scale urban habitat restoration. The BHCP is successful in some ways at administration of careful habitat assessment, and even application of vegetation standards (Gibbs 2018 1). There is evidence in this study that the standards as written, especially requirements for increases in trees, reduction of lawn, and increases in 
vegetation complexity can have positive effects on avian diversity and can be used to encourage or discourage target species. It is also likely that birds respond strongly to regional landscape variables that, despite the best of efforts by individual landowners, likely have more influence on the species present in yards than the habitat features of the yard itself. The need for larger regions of high density resources (such as parks maintained as natural areas) for some species will limit the apparent value of a highquality yard in a low-quality region, and thusly shows a need for coordinated efforts to improve large numbers of yards as a group in low-quality areas. Beyond lack of natural resources, I believe there are several behaviors humans use in yards that directly impact the vegetation and the arthropod community that indirectly limit many avian species. Mulching, mowing, leaf blowing, and fastidious pruning of plants have sterilizing effects on yards. These behaviors amount to nearly constant disturbance, removing and destroying fine litter and arthropods. Fine litter is positively associated with the most sensitive species in this study and negatively associated with the most urban preferring. Any place we can increase the volume of vegetation will increase avian abundance, richness and diversity, and will move backyard avian communities away from invasive and urban preferring species to the more native dominated assemblages sought by most landowners. However, to reach a truly natural situation in a city may be impossible, as it would require ending human disturbance of the landscape. 


\section{Chapter 3 Figures and Tables}

Figure 3.1: Study area for sampling of birds, and habitat variables from random locations (green circles) and yards (blue circles). The orange line and pink region indicate the study area. Portland, OR is outlined by a thick black line and is bordered by Vancouver WA, Gresham OR, Lake Oswego OR, Tigard OR, and Beaverton OR (clockwise from the north). The Willamette River divides Portland into east and west halves, while Burnside Street separates north from south Portland. A northwest turn in the Willamette River separates Northwest Portland (NW) from North Portland (NP). Green lines below follow these landmarks and divide the indicated regions NW, NP, Northeast Portland (NE), Southeast Portland (SE), and Southwest Portland (SW).

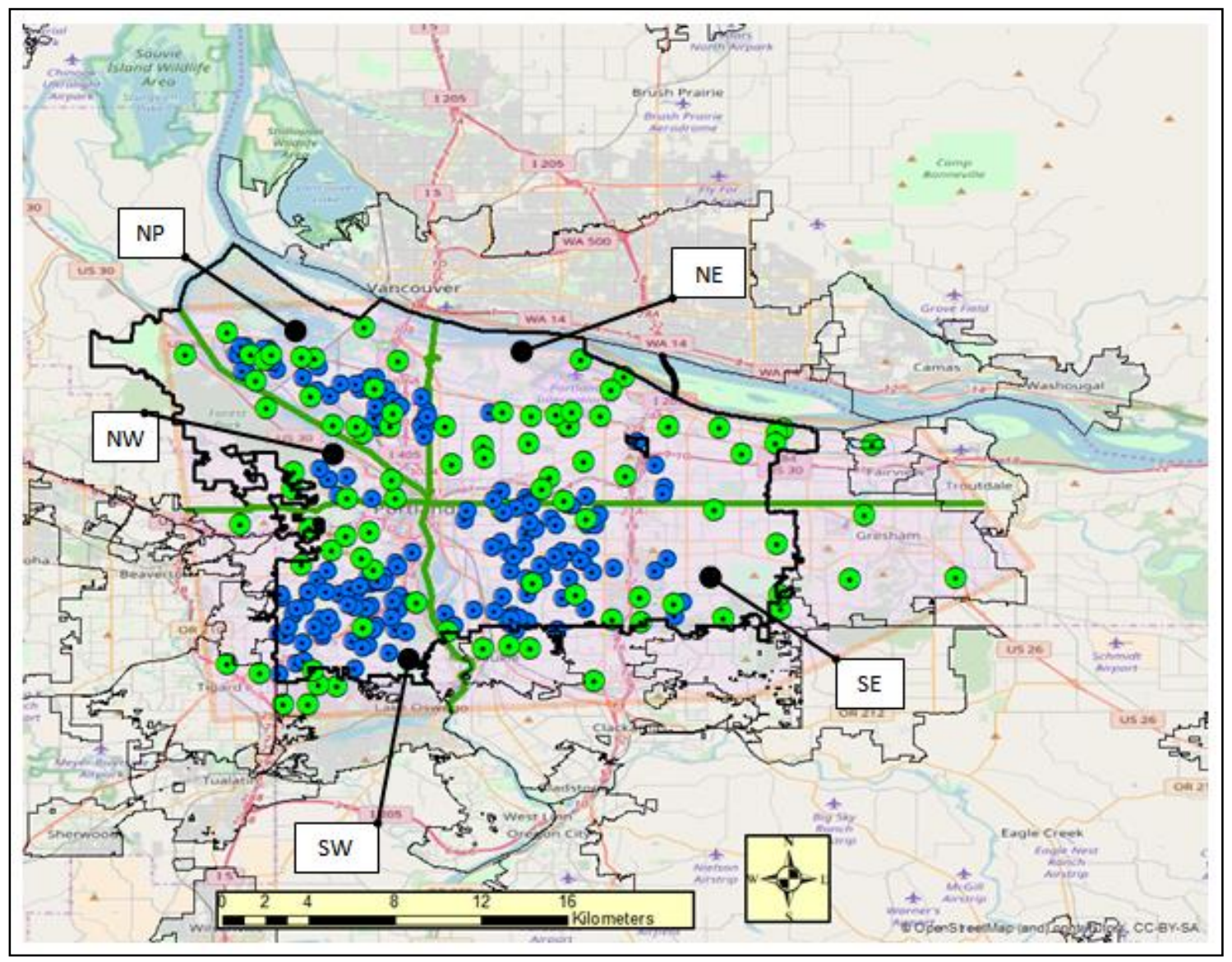


Figure 3.2: Least square means of 18 variables in 46 Not Certified, 33 Silver, 55 Gold, and 13 Platinum yards in the Audubon Society of Portland's Backyard Habitat Certification Program.

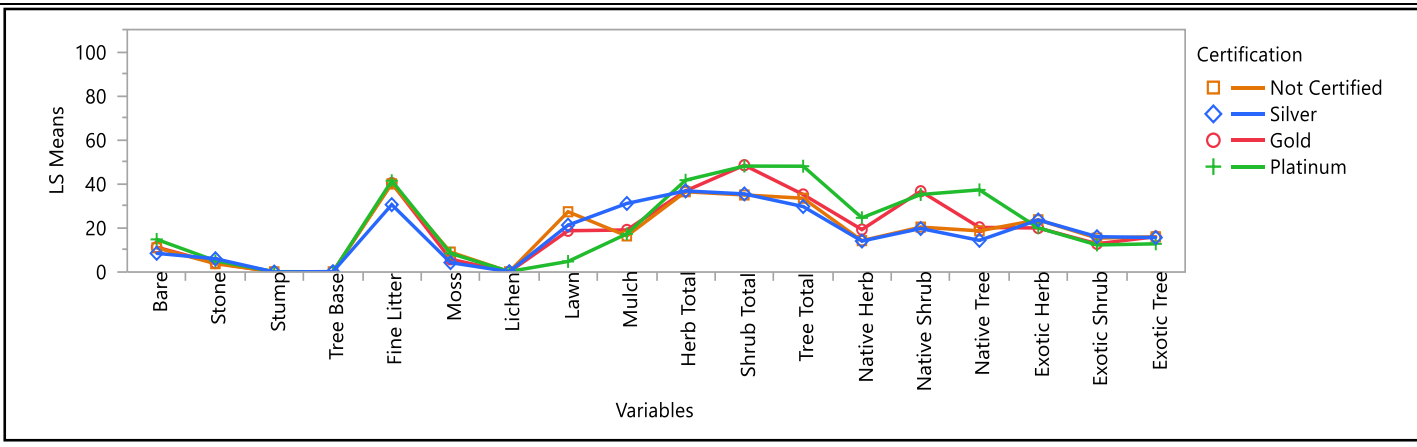


Table 3.1. ANOVA of means for total avian abundance, species richness, and species diversity among Not-certified (NC), Silver (SV), Gold (GD), and Platinum (PT) yards.

SV, GD, and PT yards are certified as wildlife habitat by the Audubon Society of Portland (ASP) Backyard Habitat Certification Program (BHCP) ANOVA was conducted with $\left(F[P]^{1}\right)$ and without $\left(F[P]^{2}\right)$ the NC yards. Numbers in parenthesis after the symbol for each certification level or NC yards indicate the number of yards sampled at each level. Each mean is followed by the standard deviation.

\begin{tabular}{|c|c|c|c|c|c|c|}
\hline & NC (46) & SV (33) & GD (54) & PT (13) & F (P) $)^{1}$ & $\mathrm{~F} \mathrm{(P)}$ \\
\hline $\begin{array}{c}\text { Abundanc } \\
\text { e }\end{array}$ & $5.48(3.40)$ & $\begin{array}{c}4.27 \\
(2.89)\end{array}$ & $5.36(3.44)$ & $\begin{array}{c}6.00 \\
(3.70)\end{array}$ & $\begin{array}{c}1.26 \\
(0.29)\end{array}$ & $\begin{array}{c}1.68 \\
(0.19)\end{array}$ \\
\hline Richness & $2.08(0.98)$ & $\begin{array}{c}1.73 \\
(0.97)\end{array}$ & $1.99(0.92)$ & $\begin{array}{c}2.29 \\
(0.83)\end{array}$ & $\begin{array}{c}1.38 \\
(0.25)\end{array}$ & $\begin{array}{c}1.85 \\
(0.16)\end{array}$ \\
\hline Diversity & $1.69(0.50)$ & $\begin{array}{c}1.57 \\
(0.49)\end{array}$ & $1.74(0.49)$ & $\begin{array}{c}1.94 \\
(0.34)\end{array}$ & $\begin{array}{c}2.26 \\
(0.084)\end{array}$ & $\begin{array}{c}3.48 \\
(0.035)\end{array}$ \\
\hline
\end{tabular}




\begin{tabular}{|c|c|c|c|c|c|c|}
\hline $\begin{array}{l}\text { radius } 150 \mathrm{n} \\
\text { each variabl } \\
\text { the } 150 \mathrm{~m} \mathrm{fi} \\
\text { between } 15 \\
\text { the final } 2 \mathrm{cc}\end{array}$ & $\begin{array}{l}\text { or } 500 \mathrm{~m} \text { th } \\
\text { contain the } \\
\mathrm{m} \text { and } 500 \\
\text { umns. }\end{array}$ & $\begin{array}{l}\text { mean, max } \\
\text { n circles se } \\
\text { values of }\end{array}$ & $\begin{array}{l}\text { d } 146 \text { yard } \\
\text { num, mini } \\
\text { ach variab }\end{array}$ & $\begin{array}{l}\text { in Portlanc } \\
\text { im, and st } \\
\text { at the two }\end{array}$ & $\begin{array}{l}\text { regon. } \\
\text { lard de } \\
\text { ts }(r) \text { a } \\
\text { tances }\end{array}$ & $\begin{array}{l}\text { for } \\
\text { on for } \\
\text { Ipha (p) } \\
\text { given in }\end{array}$ \\
\hline Variable & Mean & Max & Min & SD & $r$ & $p$ \\
\hline Canopy cover & $35.7,34.8$ & $74.9,73.8$ & $13.3,14.2$ & $14.6,14.6$ & 0.886 & $<0.001$ \\
\hline $\begin{array}{c}\text { Population } \\
\text { density }\end{array}$ & $24.5,23.0$ & $58.9,41.8$ & $5.5,5.0$ & $9.8,8.5$ & 0.816 & $<0.001$ \\
\hline $\begin{array}{l}\text { Impervious } \\
\text { Surface }\end{array}$ & $41.2,42.5$ & $67.7,64.7$ & $15.3,17.5$ & $11.7,11.3$ & 0.828 & $<0.001$ \\
\hline Soil or Bare & $0.03,0.07$ & $2.5,1.2$ & 0,0 & $0.23,0.15$ & 0.133 & 0.11 \\
\hline $\begin{array}{c}\text { Grass/ } \\
\text { herbaceous }\end{array}$ & $24.3,23.6$ & $43.4,39.5$ & $8.4,4.6$ & $6.5,6.0$ & 0.723 & $<0.001$ \\
\hline Water & $0.025,0.19$ & $1.3,8.5$ & 0,0 & $0.15,0.92$ & 0.063 & 0.45 \\
\hline Total Green & $58.7,57.2$ & $84.7,82.5$ & $32.3,35.0$ & $11.7,11.4$ & 0.825 & $<0.001$ \\
\hline
\end{tabular}




\begin{tabular}{|c|c|c|c|c|}
\hline \multicolumn{5}{|c|}{ Eigenvectors (150) } \\
\hline Variables & PC1 & PC2 & PC3 & PC4 \\
\hline Canopy cover & -0.564 & -0.075 & -0.106 & ---- \\
\hline Population density & 0.509 & -0.174 & 0.072 & ---- \\
\hline Impervious Surface & 0.540 & -0.177 & 0.059 & --- \\
\hline Soil or Bare & 0.070 & 0.691 & -0.574 & ---- \\
\hline Grass/herbaceous & 0.305 & 0.545 & 0.181 & ---- \\
\hline Water & -0.183 & 0.398 & 0.786 & ---- \\
\hline Eigenvalue & 2.914 & 1.126 & 0.949 & ---- \\
\hline Variation (\%) & 48.6 & 18.8 & 15.8 & $\begin{array}{ll}--- \\
\end{array}$ \\
\hline Cumulative variation (\%) & 48.6 & 67.3 & 83.2 & ---- \\
\hline \multicolumn{5}{|c|}{ Eigenvectors (500) } \\
\hline Canopy cover & -0.561 & -0.020 & 0.097 & ---- \\
\hline Population density & 0.499 & -0.244 & -0.120 & $-{ }_{---}$ \\
\hline Impervious Surface & 0.521 & -0.027 & -0.272 & $\begin{array}{ll}--- \\
\end{array}$ \\
\hline Soil or Bare & 0.147 & 0.650 & 0.566 & $\begin{array}{ll}--- \\
\end{array}$ \\
\hline Grass/herbaceous & 0.377 & 0.016 & 0.505 & ---- \\
\hline Water & 0.032 & 0.718 & -0.571 & ---- \\
\hline Eigenvalue & 3.014 & 1.169 & 0.940 & $\begin{array}{ll}--- \\
\end{array}$ \\
\hline Variation (\%) & 50.2 & 19.5 & 15.7 & ---- \\
\hline Cumulative variation (\%) & 50.2 & 69.7 & 85.4 & $\begin{array}{c}--- \\
\end{array}$ \\
\hline \multicolumn{5}{|c|}{ Eigenvectors (Yard) } \\
\hline Fine Litter & 0.603 & 0.231 & -0.211 & 0.055 \\
\hline Lawn & -0.526 & 0.055 & -0.519 & 0.112 \\
\hline Mulch & 0.190 & -0.678 & 0.088 & -0.259 \\
\hline Herb Total & 0.010 & 0.275 & 0.501 & -0.592 \\
\hline Shrub Total & 0.312 & -0.236 & 0.265 & 0.644 \\
\hline Tree Total & 0.426 & 0.418 & -0.346 & -0.096 \\
\hline Bare & -0.211 & 0.422 & 0.488 & 0.379 \\
\hline Eigenvalue & 1.838 & 1.506 & 1.221 & 1.081 \\
\hline Variation (\%) & 26.3 & 21.5 & 17.5 & 15.5 \\
\hline Cumulative variation (\%) & 26.3 & 47.8 & 65.2 & 80.7 \\
\hline
\end{tabular}




\begin{tabular}{|c|c|c|c|}
\hline \multicolumn{4}{|c|}{$\begin{array}{l}\text { Table 3.4. Correlation coefficients ( } r \text { ) and alpha }(P) \text { in parenthesis for total avian } \\
\text { abundance (mean number of birds per survey), species richness (mean number of } \\
\text { species per survey), and species diversity (Shannon-Weiner Index) when compared } \\
\text { to habitat variables. Shown here are variables or PCA eigenvectors that showed } \\
\text { significant variation correlation with any response variable. Non-significant = ns. }\end{array}$} \\
\hline Variables & Abundance & Richness & Diversity \\
\hline Herb Total & $0.104(0.209) \mathrm{ns}$ & $0.215(0.009)$ & $0.232(0.005)$ \\
\hline Tree Total & $0.108(0.192) \mathrm{ns}$ & $0.194(0.019)$ & $0.145(0.08) \mathrm{ns}$ \\
\hline Native Tree & $0.12(0.15) \mathrm{ns}$ & $0.258(0.002)$ & $0.249(0.002)$ \\
\hline Bare & $0.097(0.241) \mathrm{ns}$ & $0.114(0.168) \mathrm{ns}$ & $0.163(0.048)$ \\
\hline Stone & $\begin{array}{r}-0.013(0.876) \\
n s \\
\end{array}$ & $\begin{array}{r}-0.121(0.144) \\
n s \\
\end{array}$ & $-0.211(0.010)$ \\
\hline Fine Litter & $0.163(0.049)$ & $0.215(0.009)$ & $0.202(0.014)$ \\
\hline Mulch & $-0.205(0.013)$ & $-0.266(0.001)$ & $-0.233(0.004)$ \\
\hline Planted area & $0.287(<.001)$ & $0.542(<.001)$ & $0.491(<.001)$ \\
\hline $\mathrm{PC}_{2} \mathrm{Yard}$ & $0.280(<.001)$ & $0.351<.001)$ & $0.338(<.001)$ \\
\hline Canopy $30 \mathrm{~m}$ & $0.075(0.37) \mathrm{ns}$ & $0.389(<.001)$ & $0.329(<.001)$ \\
\hline 150 m Canopy & $0.274(<.001)$ & $0.589(<.001)$ & $0.547(<.001)$ \\
\hline 150 m Population & $-0.300(<.001)$ & $-0.659(<.001)$ & $-0.687(<.001)$ \\
\hline $150 \mathrm{~m}$ Impervious & $-0.342(<.001)$ & $-0.624(<.001)$ & $-0.585(<.001)$ \\
\hline 150 m Grass/Herb & $0.02(0.814) \mathrm{ns}$ & $-0.215(0.009)$ & $-0.194(0.018)$ \\
\hline $150 \mathrm{~m}$ Water & $0.077(0.354) \mathrm{ns}$ & $0.190(0.021)$ & $.064(.443) \mathrm{ns}$ \\
\hline 150 m Total green & $0.343(<.001)$ & $0.624(<.001)$ & $0.586(<.001)$ \\
\hline $\mathrm{PC}_{1} 150 \mathrm{~m}$ & $-0.295(<.001)$ & $-0.649(<.001)$ & $-0.613(<.001)$ \\
\hline 500 m Canopy & $0.417(<.001)$ & $0.537(<.001)$ & $0.523(<.001)$ \\
\hline 500 m Population & $-0.404(<.001)$ & $-0.551(<.001)$ & $-0.524(<.001)$ \\
\hline $500 \mathrm{~m}$ Impervious & $-0.439(<.001)$ & $-0.553(<.001)$ & $-0.535(<.001)$ \\
\hline 500 m Grass/Herb & $-0.140(.093) n s$ & $-0.254(0.002)$ & $-0.262(0.001)$ \\
\hline $500 \mathrm{~m}$ Woody Wetlands & $0.174(0.036)$ & $0.250(0.002)$ & $.026(.755) \mathrm{ns}$ \\
\hline $500 \mathrm{~m}$ Total green & $0.439(<.001)$ & $0.546(<.001)$ & $0.530(<.001)$ \\
\hline $\mathrm{PC}_{1} 500 \mathrm{~m}$ & $-0.417(<.001)$ & $-0.562(<.001)$ & $-0.544(<.001)$ \\
\hline
\end{tabular}




\begin{tabular}{|c|c|c|c|}
\hline \multicolumn{4}{|c|}{ in yards from Portland, OR, measured in the summers of 2014 and 2015 in relation } \\
\hline \multicolumn{4}{|c|}{ to landscape and yard habitat variables. Predictor variables in models are listed in } \\
\hline \multicolumn{4}{|c|}{ order of effect from strongest to weakest. Results describing non-competitive } \\
\hline mode & $s(\Delta A I C c>2.000)$ were not included (with one exception). & & \\
\hline $\begin{array}{c}\text { Mod } \\
\text { el }\end{array}$ & Variables & $\triangle \mathrm{AlCc}$ & $R^{2}$ \\
\hline 1 & $\begin{array}{l}\mathrm{PC}_{1} 150 \mathrm{~m}(-), 150 \mathrm{~m} \text { Grass and Herbaceous }(+) \text {, Herbaceous } \\
\text { yard }(+) \text {, Exotic shrub (+) }\end{array}$ & 0.000 & $\begin{array}{r}0.31 \\
0\end{array}$ \\
\hline 2 & $\begin{array}{l}\mathrm{PC}_{1} 150 \mathrm{~m}(-), 150 \mathrm{~m} \text { Grass and Herbaceous (+), Herbaceous } \\
\text { yard (+) }\end{array}$ & 0.083 & $\begin{array}{r}0.29 \\
9\end{array}$ \\
\hline 3 & $\mathrm{PC}_{1} 150 \mathrm{~m}(-), 150 \mathrm{~m}$ Grass and Herbaceous (+), Mulch (-) & 2.022 & $\begin{array}{r}0.29 \\
0\end{array}$ \\
\hline
\end{tabular}




\begin{tabular}{|c|c|c|c|}
\hline Model & Variables & $\triangle \mathrm{AICC}$ & $R^{2}$ \\
\hline 1 & $\begin{array}{l}\mathrm{PC}_{1} 150 \mathrm{~m}(-), 150 \mathrm{~m} \text { Grass and Herbaceous (+), Mulch (-), } \\
\text { Planted area (+) }\end{array}$ & 0.000 & 0.491 \\
\hline 2 & $\begin{array}{l}\mathrm{PC}_{1} 150 \mathrm{~m}(-), \text { Vertical Obstruction (+), Mulch (-), Planted } \\
\text { area (+) }\end{array}$ & 0.012 & 0.491 \\
\hline 3 & $\mathrm{PC}_{1} 150 \mathrm{~m}(-)$, Mulch (-), Planted area (+) & 0.997 & 0.480 \\
\hline 4 & $\begin{array}{l}\mathrm{PC}_{1} 150 \mathrm{~m}(-), 150 \mathrm{~m} \text { Grass and Herbaceous (+), Planted } \\
\text { area (+) }\end{array}$ & 1.148 & 0.479 \\
\hline 5 & $\mathrm{PC}_{1} 150 \mathrm{~m}(-)$, Vertical Obstruction (+), Planted area (+) & 1.737 & 0.477 \\
\hline 6 & $\mathrm{PC}_{1} 150 \mathrm{~m}(-)$, Planted area (+) & 2.27 & 0.468 \\
\hline
\end{tabular}




\begin{tabular}{|c|c|c|c|}
\hline \multicolumn{4}{|c|}{ Variables are listed in order of effect from strongest to weakest. } \\
\hline Model & Variables & $\triangle \mathrm{AICc}$ & $R^{2}$ \\
\hline 1 & $\begin{array}{l}\mathrm{PC}_{1} 150 \mathrm{~m}(-), \text { Vertical Obstruction (+), Mulch (-), } \\
\text { Planted area (+) }\end{array}$ & 0.000 & 0.455 \\
\hline 2 & $\begin{array}{l}\mathrm{PC}_{1} 150 \mathrm{~m}(-), \text { Water } 150 \mathrm{~m}(-), \text { Vertical } \\
\text { Obstruction (+), Planted area (+) }\end{array}$ & 0.234 & 0.454 \\
\hline 3 & $\begin{array}{l}\mathrm{PC}_{1} 150 \mathrm{~m}(-), \mathrm{PC}_{2} \text { Yards }(+), \text { Vertical Obstruction } \\
(+), \text { Planted area }(+)\end{array}$ & 0.561 & 0.453 \\
\hline 4 & $\begin{array}{l}\mathrm{PC}_{1} 150 \mathrm{~m}(-), 150 \mathrm{~m} \text { Grass and Herbaceous (+), } \\
\text { Vertical Obstruction (+), Planted area (+) }\end{array}$ & 0.945 & 0.452 \\
\hline 5 & $\begin{array}{l}\mathrm{PC}_{1} 150 \mathrm{~m}(-) \text {, Vertical Obstruction (+), Planted } \\
\text { area (+) }\end{array}$ & 1.288 & 0.442 \\
\hline
\end{tabular}




\begin{tabular}{|c|c|c|c|c|c|c|c|c|c|c|}
\hline \multicolumn{11}{|c|}{$\begin{array}{l}\text { highlighted with blue, positive with green. This is continued in table } 3.9 \text { with variables for which } 6 \\
\text { or fewer species responded. "Type" refers to apparent relationship to urban environments, with UA }\end{array}$} \\
\hline 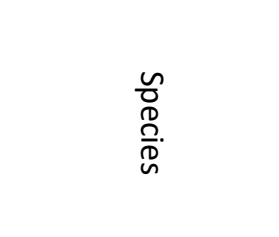 & $\underset{D}{\stackrel{1}{D}}$ & 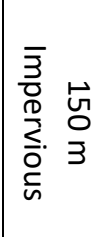 & 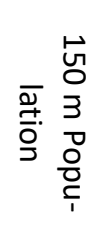 & $\begin{array}{l}\text { 봉 } \\
3 \\
3 \\
8 \\
\frac{\partial}{2} \\
\frac{0}{2}\end{array}$ & 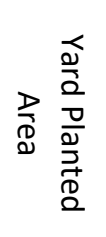 & 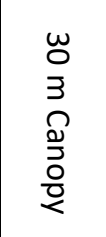 & 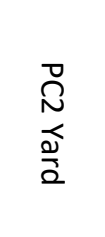 & 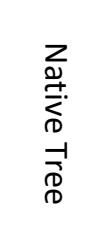 & 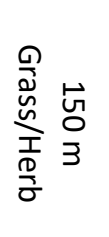 & 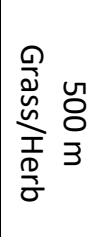 \\
\hline 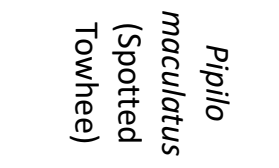 & $\subsetneq$ & 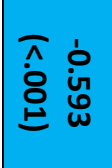 & $\begin{array}{l}\pi \\
\dot{\delta} \\
\dot{\delta}\end{array}$ & $\begin{array}{ll}\pi & 0 \\
\dot{\hat{\theta}} & \dot{\delta} \\
\ominus & 0\end{array}$ & $\begin{array}{l}\pi \hat{\dot{\theta}} \\
\dot{\delta} \\
\dot{\varphi}\end{array}$ & $\begin{array}{ll}\pi & 0 \\
\dot{\hat{\delta}} & \dot{\theta} \\
\dot{\ominus} & \sigma\end{array}$ & $\begin{array}{l}\hat{\dot{\hat{\delta}}} \\
\stackrel{\dot{\omega}}{\dot{\omega}} \\
\stackrel{\infty}{\infty}\end{array}$ & 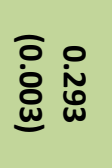 & $\begin{array}{ll}\overline{0} & 1 \\
\dot{0} & 0 \\
0 & 0 \\
\equiv & w\end{array}$ & 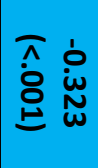 \\
\hline 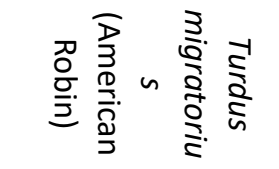 & $\stackrel{\subsetneq}{\triangleright}$ & $\begin{array}{ll}\pi & \dot{0} \\
\dot{\delta} & \dot{i} \\
\dot{\theta} & \end{array}$ & $\begin{array}{l}\pi \hat{0} \\
\dot{\delta} \\
\dot{\delta}\end{array}$ & $\begin{array}{ll}\pi & 0 \\
\dot{\delta} & \dot{0} \\
\dot{\theta} & \omega\end{array}$ & $\begin{array}{ll}\pi & 0 \\
\dot{\delta} & \stackrel{+}{+} \\
\dot{\omega}\end{array}$ & 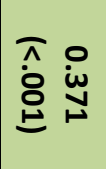 & 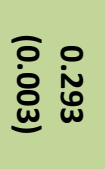 & $\begin{array}{l} \\
\\
\dot{8}\end{array}$ & 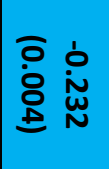 & $\begin{array}{ll}\pi & \dot{\hat{\phi}} \\
\dot{\delta} & \underset{\omega}{\omega} \\
\dot{\infty}\end{array}$ \\
\hline 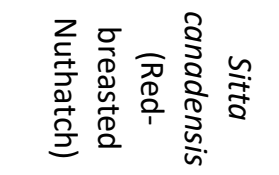 & $\stackrel{\subsetneq}{\triangleright}$ & 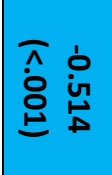 & $\begin{array}{l}\pi \\
\dot{\delta} \\
\dot{\delta} \\
\dot{E}\end{array}$ & 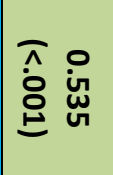 & $\begin{array}{l}\overline{\hat{\alpha}} \\
\dot{\delta} \\
\dot{\omega}\end{array}$ & 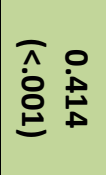 & 욜 & 술 & 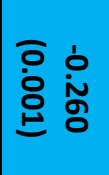 & 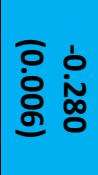 \\
\hline 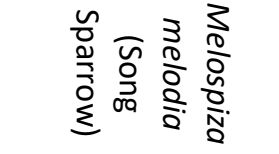 & $\stackrel{\subsetneq}{\triangleright}$ & $\begin{array}{l}\overline{\hat{\alpha}} \dot{0} \\
\dot{0} \dot{\circ}\end{array}$ & $\begin{array}{l}\pi \hat{\hat{\theta}} \\
\dot{\delta} \\
\dot{\ominus}\end{array}$ & $\begin{array}{ll}\pi & 0 \\
\dot{\dot{\delta}} & \stackrel{i}{\dot{H}} \\
\stackrel{N}{*}\end{array}$ & $\begin{array}{l}\overline{\hat{\theta}} \\
\dot{\delta} \\
\dot{\rho}\end{array}$ & 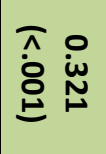 & $\begin{array}{l}\text { 웅 } \\
\dot{\circ} \\
\dot{0}\end{array}$ & 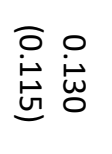 & 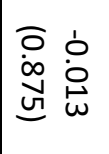 & 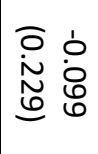 \\
\hline 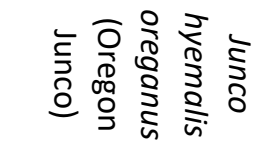 & $\stackrel{\subsetneq}{\lessgtr}$ & $\begin{array}{ll}\pi & \dot{\hat{\theta}} \\
\dot{\delta} & \dot{\theta} \\
\dot{\theta} & \end{array}$ & 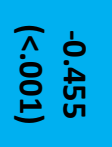 & 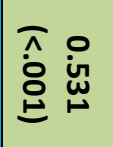 & $\begin{array}{l}\overline{\hat{\alpha}} \\
\dot{\delta} \\
\dot{\phi}\end{array}$ & 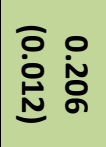 & $\begin{array}{l}\text { 웅 } \\
\dot{0} \\
\dot{0}\end{array}$ & $\begin{array}{l}\overline{0} \\
\dot{0} \\
\dot{O}\end{array}$ & $\begin{array}{ll} & 1 \\
0 & 0 \\
0 & 0 \\
0 & 0 \\
\end{array}$ & 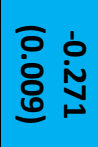 \\
\hline 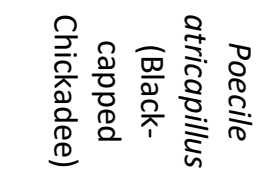 & $\stackrel{\subsetneq}{\triangleright}$ & 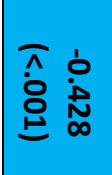 & 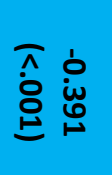 & $\begin{array}{ll}\pi & 0 \\
\dot{\delta} & \dot{\omega} \\
\stackrel{\omega}{E} & \end{array}$ & $\begin{array}{l}\hat{\hat{i}} \\
\dot{\delta} \\
\dot{\varphi}\end{array}$ & 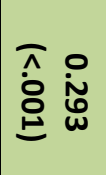 & $\begin{array}{l}0 \\
\dot{\circ} \\
\dot{0}\end{array}$ & $\begin{array}{l}\overline{0} \\
\dot{0} \\
0\end{array}$ & 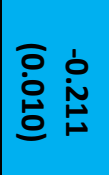 & 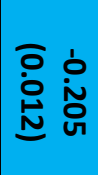 \\
\hline
\end{tabular}




\begin{tabular}{|c|c|c|c|c|c|c|c|c|c|c|}
\hline 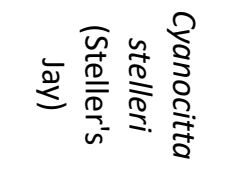 & $\subsetneq$ & 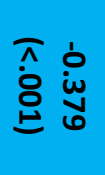 & $\begin{array}{l}\overline{0} \\
\dot{0} \\
\dot{0} \\
\underline{\tilde{L}}\end{array}$ & 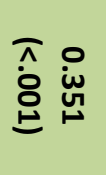 & 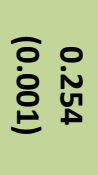 & 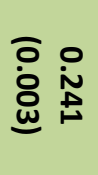 & 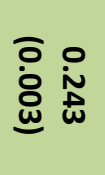 & 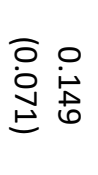 & 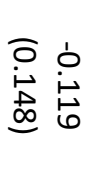 & 엉 \\
\hline 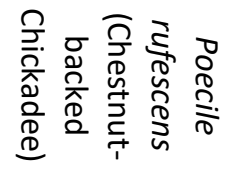 & $\subsetneq$ & 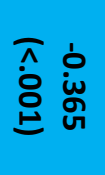 & 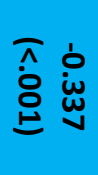 & 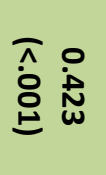 & $\begin{array}{l}\pi \\
\hat{\dot{\delta}} \\
\dot{\phi}\end{array}$ & $\begin{array}{l}\bar{\partial} \\
\dot{0} \\
\dot{\tilde{U}} \\
\underline{\omega}\end{array}$ & 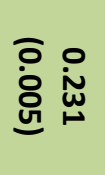 & 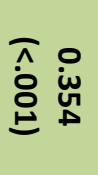 & 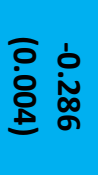 & $\begin{array}{l}0 \dot{0} \\
\dot{\sim} \\
\dot{\Theta}\end{array}$ \\
\hline 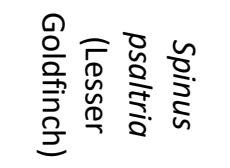 & $\subsetneq$ & 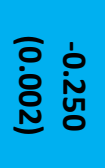 & 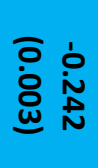 & 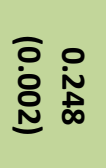 & $\begin{array}{ll}\bar{\partial} & 0 \\
\dot{\omega} & 0 \\
0 \\
0\end{array}$ & 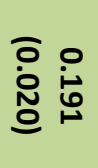 & 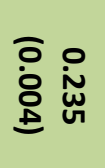 & $\begin{array}{l}\overline{0} \\
\text { ஸे } \\
\infty \\
\infty \\
\infty\end{array}$ & $\begin{array}{ll} & 0 \\
\dot{\omega} & 0 \\
0 & \dot{O} \\
\infty & 0\end{array}$ & 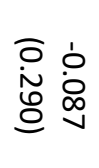 \\
\hline 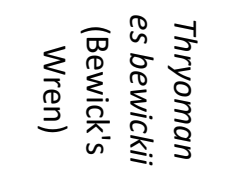 & $\subsetneq$ & 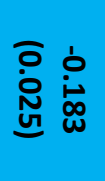 & 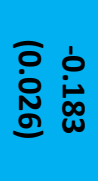 & 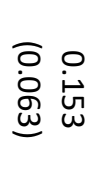 & $\begin{array}{l}\pi \\
\hat{\dot{\delta}} \\
\dot{\theta}\end{array}$ & 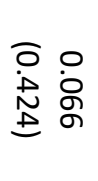 & 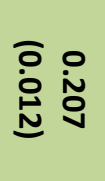 & 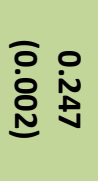 & 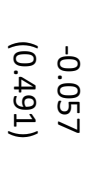 & 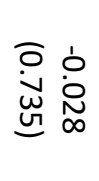 \\
\hline 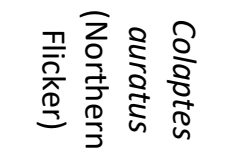 & $\subsetneq$ & 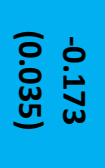 & 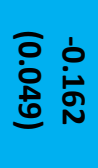 & $\begin{array}{l}\text { OO } \\
\dot{N} \\
\dot{0} \\
\text { 으 }\end{array}$ & 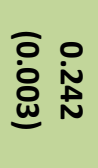 & 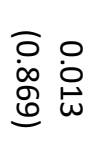 & 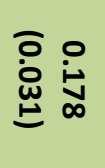 & 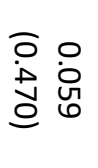 & 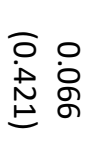 & $\begin{array}{l}\overline{0} \\
\dot{0} \\
\dot{0} \\
\underline{E}\end{array}$ \\
\hline 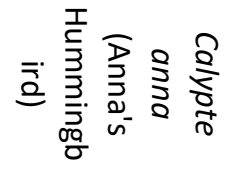 & $\subsetneq$ & 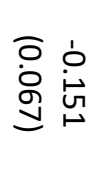 & 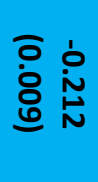 & 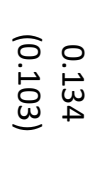 & 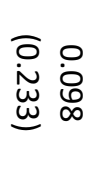 & 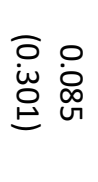 & $\begin{array}{l}\bar{O} \\
\dot{N} \\
\underline{U} \\
\end{array}$ & 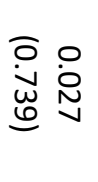 & 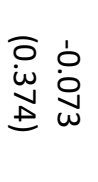 & $\begin{array}{ll} & 0 \\
\dot{\omega} & 0 \\
\dot{\omega} & 0 \\
\omega & 0\end{array}$ \\
\hline 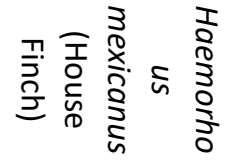 & $\subsetneq$ & 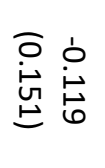 & $\begin{array}{ll} & 0 \\
\dot{\omega} & 0 \\
0 & 0 \\
0 & \infty \\
0\end{array}$ & $\begin{array}{l}\text { 응 } \\
\text { 윰 } \\
\text { 븡 }\end{array}$ & 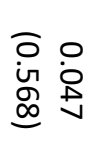 & 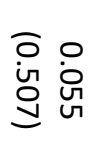 & 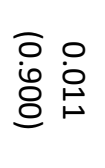 & 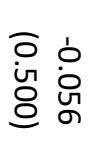 & 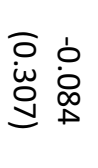 & 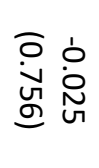 \\
\hline 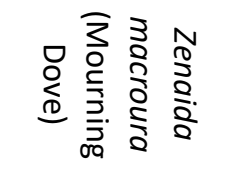 & $\subsetneq$ & $\begin{array}{ll}\overline{0} & \dot{0} \\
\text { No } & \dot{0} \\
0 & \infty \\
0 & 0\end{array}$ & 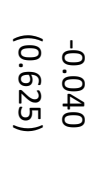 & 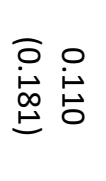 & 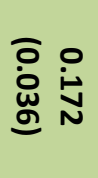 & 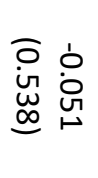 & 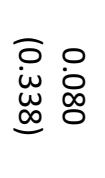 & 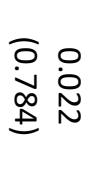 & 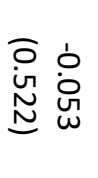 & 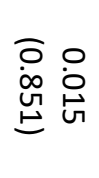 \\
\hline 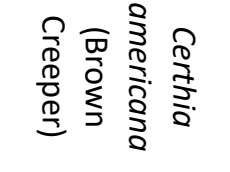 & $\subsetneq$ & $\begin{array}{ll}\bar{O} & \dot{0} \\
\dot{\omega} & \dot{0} \\
\stackrel{\omega}{\simeq} & \infty \\
\omega\end{array}$ & 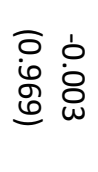 & 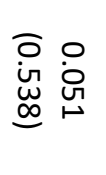 & 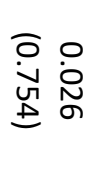 & 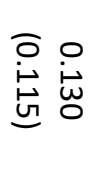 & $\begin{array}{l}\text { 응 } \\
\text { 옹 } \\
\text { 응 }\end{array}$ & $\begin{array}{l}\overline{0} \\
\tilde{N} \\
\tilde{G} \\
\sigma\end{array}$ & 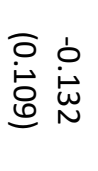 & 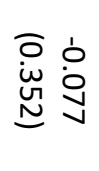 \\
\hline 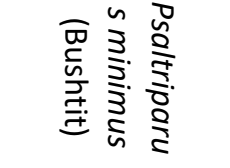 & $\subsetneq$ & 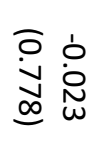 & $\begin{array}{l}\bar{\partial} \\
\dot{\phi} \\
\dot{\omega} \\
\underline{\omega}\end{array}$ & 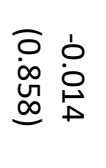 & 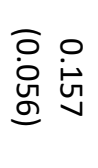 & $\begin{array}{l}0 \\
\dot{D} \\
\dot{\omega} \\
\underline{\omega}\end{array}$ & $\begin{array}{l}\text { Oo } \\
\text { in } \\
\text { 옵 }\end{array}$ & $\begin{array}{ll} & 0 \\
\dot{0} & 0 \\
\dot{\omega} & \dot{8} \\
\infty & 0\end{array}$ & 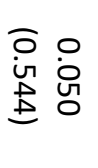 & 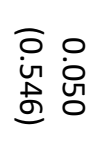 \\
\hline 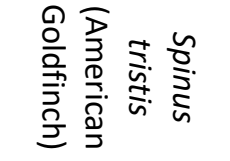 & $\subsetneq$ & 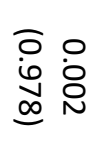 & 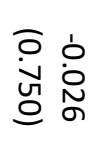 & 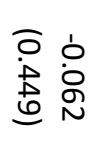 & 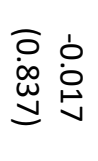 & 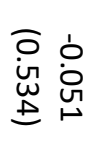 & 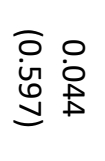 & 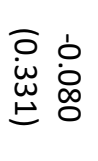 & 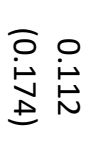 & 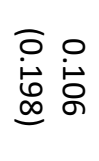 \\
\hline
\end{tabular}




\begin{tabular}{|c|c|c|c|c|c|c|c|c|c|c|}
\hline 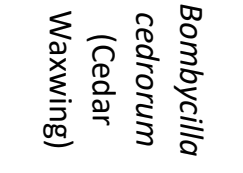 & $\subsetneq$ & 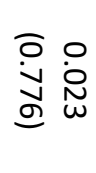 & $\begin{array}{l}\overline{0} \\
\dot{0} \\
\stackrel{8}{0}\end{array}$ & $\begin{array}{l}\overline{0} \\
\text { 出定 } \\
\text { 它 }\end{array}$ & 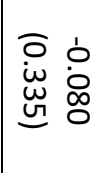 & 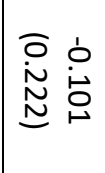 & $\begin{array}{l}\bar{D} \\
\dot{d} \\
\underline{\omega} \\
\underline{\omega}\end{array}$ & 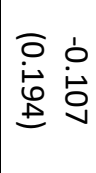 & 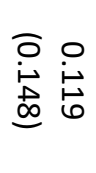 & 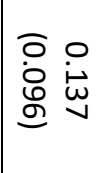 \\
\hline 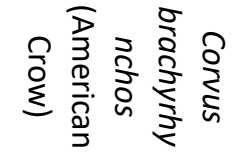 & $\subsetneq$ & $\begin{array}{l}\bar{O} \\
\dot{D} \\
\text { Dِ }\end{array}$ & 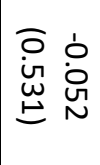 & 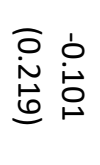 & 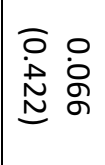 & 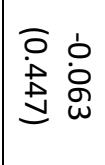 & 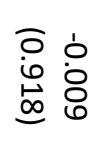 & 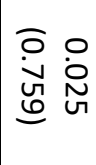 & $\begin{array}{l}\vec{\partial} \\
\dot{\omega} \\
\infty \\
\infty \\
\infty\end{array}$ & 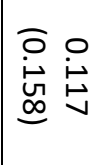 \\
\hline 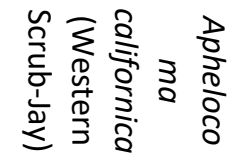 & $\subsetneq$ & 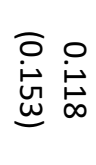 & 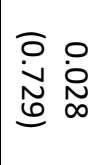 & $\begin{array}{l}\bar{O} \dot{0} \\
\dot{\tilde{D}} \\
\stackrel{\dot{\sigma}}{0}\end{array}$ & 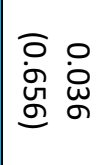 & 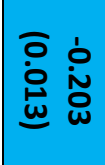 & 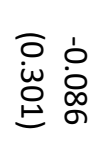 & 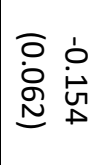 & $\begin{array}{l}\bar{\partial} \\
\dot{0} \\
\dot{\tilde{\sigma}}\end{array}$ & 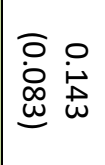 \\
\hline 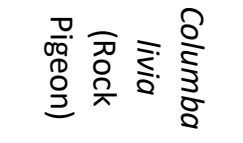 & $\subsetneq$ & 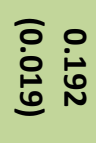 & 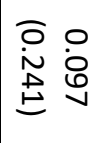 & 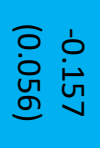 & 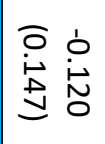 & 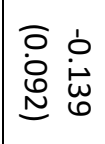 & 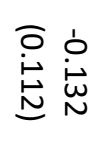 & 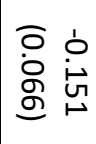 & 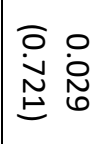 & 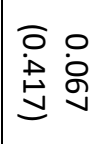 \\
\hline 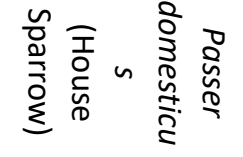 & $\subsetneq$ & 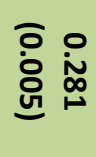 & 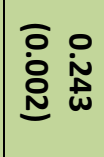 & $\begin{array}{l}\pi \hat{\hat{\phi}} \dot{\phi} \\
\dot{\phi} \\
\dot{\omega}\end{array}$ & 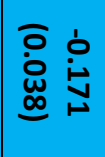 & 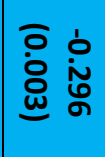 & $\begin{array}{l}\bar{O} \\
\dot{0} \\
\dot{0} \\
0 \\
0\end{array}$ & 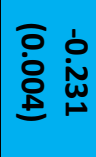 & $\begin{array}{l}\overline{\hat{\phi}} \\
\dot{\underline{\theta}}\end{array}$ & $\begin{array}{l}0 \\
\dot{0} \\
\dot{\partial} \\
\dot{\rho}\end{array}$ \\
\hline 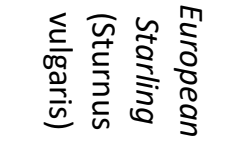 & ㄷ & $\begin{array}{l}\bar{\circ} \\
\dot{\phi} \\
\dot{\phi}\end{array}$ & $\begin{array}{l}\bar{O} \\
\dot{0} \\
\dot{\Phi}\end{array}$ & $\begin{array}{l}\pi \hat{\hat{\phi}} \\
\dot{\theta}\end{array}$ & 嵩主 & 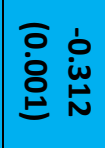 & 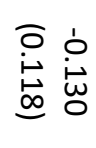 & 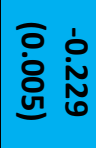 & Oे & 家 \\
\hline
\end{tabular}




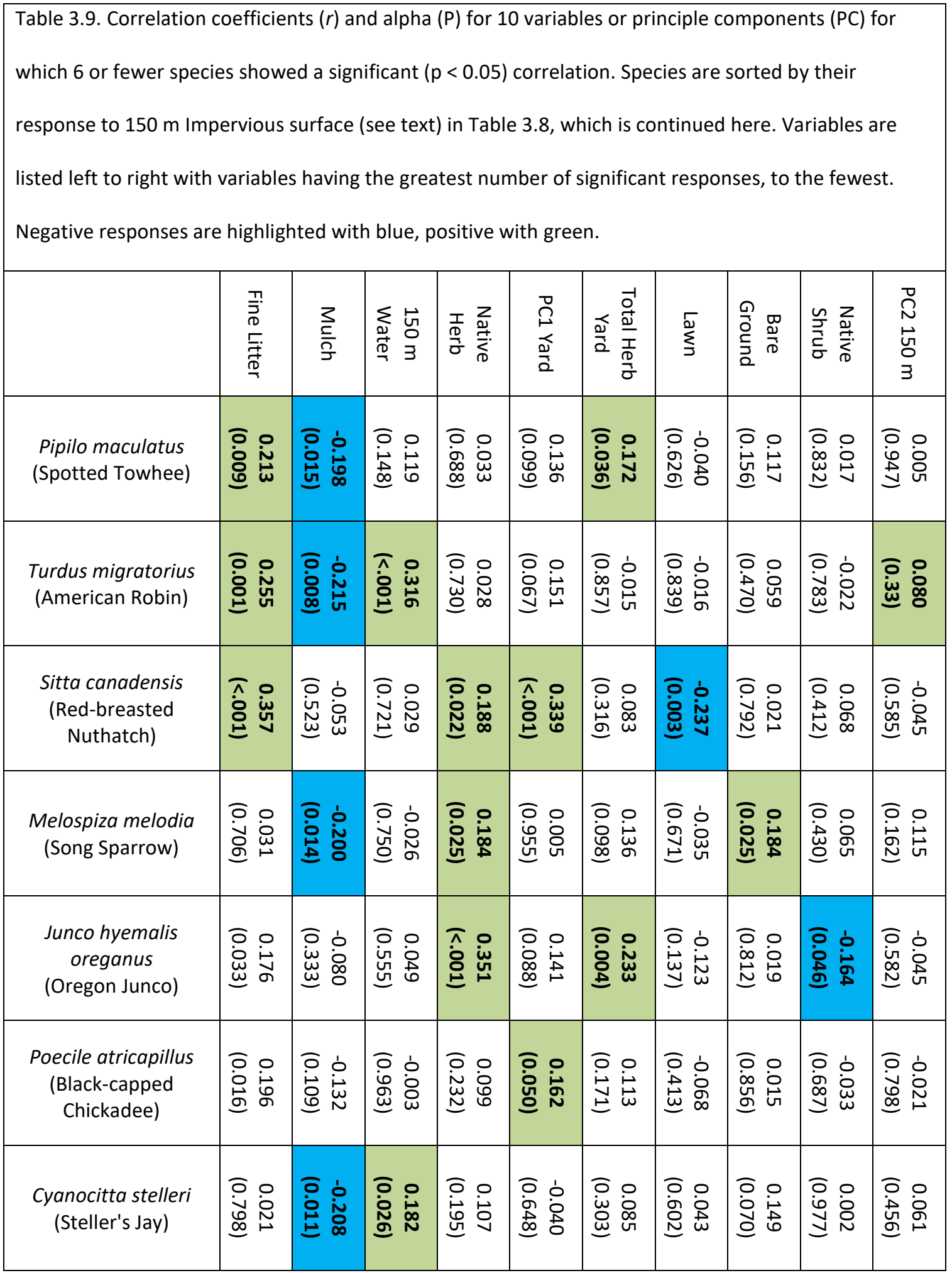




\begin{tabular}{|c|c|c|c|c|c|c|c|c|c|c|}
\hline $\begin{array}{c}\text { Poecile rufescens } \\
\text { (Chestnut-backed } \\
\text { Chickadee) }\end{array}$ & 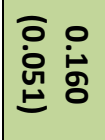 & $\begin{array}{ll}0 & 1 \\
\dot{0} & 0 \\
\dot{0} & \dot{\omega} \\
\mathfrak{G} & +\end{array}$ & $\begin{array}{ll}\text { 웅 } \\
\dot{0}\end{array}$ & $\begin{array}{ll}0 & 0 \\
\dot{\vec{b}} & \dot{\vec{w}} \\
\varrho & \sigma\end{array}$ & $\begin{array}{ll}0 & 0 \\
0 & 0 \\
N & \infty \\
0 & +\end{array}$ & 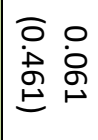 & $\begin{array}{ll}0 & 1 \\
0 & 0 \\
0 & \dot{\theta} \\
\text { ज } & 0\end{array}$ & 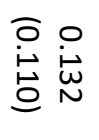 & $\begin{array}{ll}0 & 0 \\
\dot{0} & 8 \\
\varrho & 8\end{array}$ & 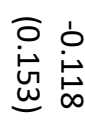 \\
\hline $\begin{array}{l}\text { Spinus psaltria } \\
\text { (Lesser Goldfinch) }\end{array}$ & 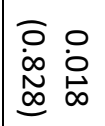 & 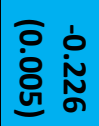 & $\begin{array}{l}\text { Oे } \\
\dot{0} \\
\dot{0}\end{array}$ & 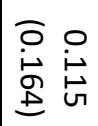 & 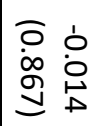 & $\begin{array}{ll}0 & 0 \\
0 & 0 \\
0 & \tilde{N} \\
0 & 0 \\
0\end{array}$ & 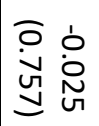 & 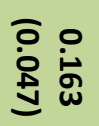 & $\mid \begin{array}{ll}0 & 1 \\
\dot{0} & 0 \\
o & 0 \\
1 & 0 \\
& \end{array}$ & 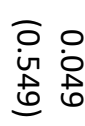 \\
\hline $\begin{array}{l}\text { Thryomanes bewickii } \\
\text { (Bewick's Wren) }\end{array}$ & 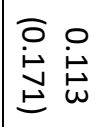 & 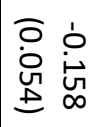 & 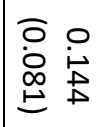 & \begin{tabular}{ll}
0 & 0 \\
0 & 0 \\
\multirow{2}{*}{} & 0 \\
0
\end{tabular} & $\begin{array}{ll} & 0 \\
\text { in } & 0 \\
\text { ज } & 0 \\
\Perp & 0\end{array}$ & $\begin{array}{ll} & 0 \\
0 & 0 \\
\text { i⿱ } & 0 \\
\ominus & \text { ज }\end{array}$ & 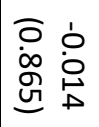 & 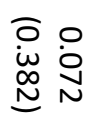 & 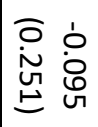 & 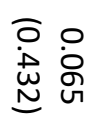 \\
\hline $\begin{array}{l}\text { Calypte anna } \\
\text { (Anna's } \\
\text { Hummingbird) }\end{array}$ & 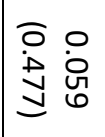 & $\begin{array}{ll}0 & 1 \\
0 & 0 \\
0 & 0 \\
0 & 0 \\
0 & 0\end{array}$ & $\begin{array}{ll}0 & 0 \\
\text { i } & 0 \\
0 & 1 \\
& \$\end{array}$ & 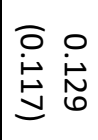 & 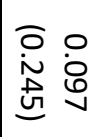 & 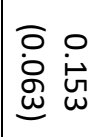 & $\begin{array}{ll}0 & 1 \\
0 & 0 \\
0 & \dot{H} \\
\text { जn } & \infty\end{array}$ & 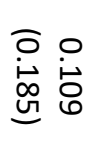 & $\mid \begin{array}{ll}0 & 1 \\
\infty & 0 \\
0 & 0 \\
\omega & 0 \\
\end{array}$ & $\begin{array}{ll}\overline{0} & 0 \\
\infty & 0 \\
\dot{\omega} & 0 \\
\underline{\omega} & \sigma\end{array}$ \\
\hline $\begin{array}{l}\text { Haemorhous } \\
\text { mexicanus } \\
\text { (House Finch) }\end{array}$ & $\begin{array}{ll}0 & 1 \\
0 & 0 \\
0 & 8 \\
0 & 8 \\
0 & 0\end{array}$ & 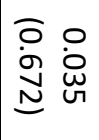 & $\begin{array}{ll}0 & 1 \\
& 0 \\
0 & 0 \\
0 & \sigma\end{array}$ & $\begin{array}{ll}0 & 0 \\
0 & 0 \\
0 & 8 \\
0 & 0\end{array}$ & 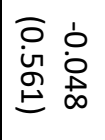 & $\begin{array}{ll}0 & 0 \\
\dot{0} & \stackrel{i}{w} \\
0 & w\end{array}$ & $\begin{array}{ll}0 & 0 \\
\dot{0} & 0 \\
\text { 릉 } & 0 \\
\text { N }\end{array}$ & 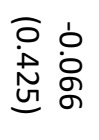 & 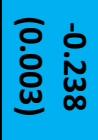 & 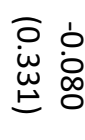 \\
\hline $\begin{array}{c}\text { Zenaida macroura } \\
\text { (Mourning Dove) }\end{array}$ & 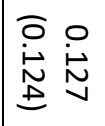 & $\begin{array}{ll} & 0 \\
\dot{0} & 0 \\
\text { o } & 0 \\
0 & 0 \\
0\end{array}$ & $\begin{array}{ll}0 & 1 \\
\text { in } & 0 \\
\infty & 0 \\
0 & 0 \\
0 & 0\end{array}$ & 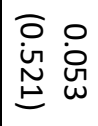 & 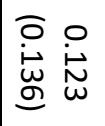 & $\begin{array}{ll}0 & 0 \\
\dot{N} & 0 \\
\infty & 0 \\
0 & 0 \\
0 & 0\end{array}$ & 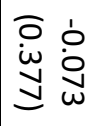 & 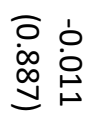 & $\begin{array}{ll}0 & 0 \\
0 & 0 \\
\dot{0} & \dot{\omega} \\
0 & w\end{array}$ & 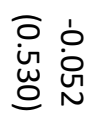 \\
\hline $\begin{array}{c}\text { Certhia americana } \\
\text { (Brown Creeper) }\end{array}$ & $\begin{array}{ll}\overline{0} & 0 \\
\dot{\tilde{\omega}} & 0 \\
\stackrel{\omega}{\ominus} & 0 \\
0\end{array}$ & $\begin{array}{ll}0 & 0 \\
\dot{0} & 0 \\
\stackrel{0}{0} & 0 \\
0\end{array}$ & $\begin{array}{ll}0 & 1 \\
0 & 0 \\
0 & 0 \\
0 & 0 \\
0 & 0\end{array}$ & $\begin{array}{ll}0 & 1 \\
\dot{y} & 0 \\
0 & 0 \\
0 & \omega\end{array}$ & $\begin{array}{ll}0 & 0 \\
i & 0 \\
0 & 0 \\
& N\end{array}$ & $\begin{array}{ll}0 & 0 \\
0 & 0 \\
0 & 0 \\
\ominus & 0 \\
\ominus & 0\end{array}$ & $\begin{array}{ll}0 & 0 \\
\text { i⿱ } & 0 \\
\omega & 0 \\
\omega & \infty\end{array}$ & $\begin{array}{ll} & 0 \\
\dot{0} & 0 \\
\dot{w} & 0 \\
0 & 0\end{array}$ & 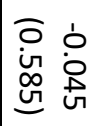 & 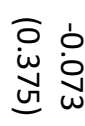 \\
\hline $\begin{array}{l}\text { Psaltriparus minimus } \\
\text { (Bushtit) }\end{array}$ & 号 & 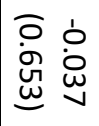 & 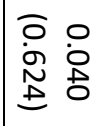 & & 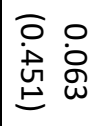 & $\mid \begin{array}{ll}0 & 0 \\
i & 0 \\
\infty & \dot{0} \\
0 & 0\end{array}$ & 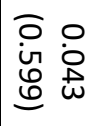 & 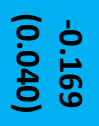 & $\begin{array}{ll}\overline{0} & 1 \\
\dot{\omega} & 0 \\
\omega & 0 \\
\omega & 0 \\
0\end{array}$ & 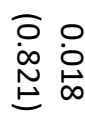 \\
\hline $\begin{array}{l}\text { Bombycilla cedrorum } \\
\text { (Cedar Waxwing) }\end{array}$ & 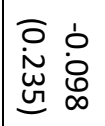 & 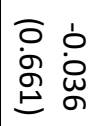 & $\begin{array}{ll} & 0 \\
\dot{\tilde{N}} & \\
\dot{\theta} & 0\end{array}$ & 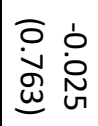 & 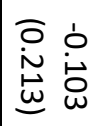 & $\begin{array}{ll}0 & 0 \\
\dot{w} & 0 \\
\underset{\sim}{\sim} & 0 \\
0 & 0\end{array}$ & 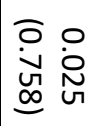 & 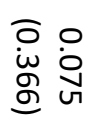 & $\begin{array}{ll} & 0 \\
0 & 0 \\
\text { in } & 0 \\
& 0 \\
\end{array}$ & 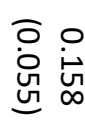 \\
\hline $\begin{array}{c}\text { Corvus } \\
\text { brachyrhynchos } \\
\text { (American Crow) }\end{array}$ & 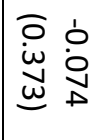 & $\begin{array}{ll}\overline{0} & 1 \\
\dot{N} & 0 \\
0 & 0 \\
0 & 0\end{array}$ & $\begin{array}{ll}0 & \dot{0} \\
\dot{0} & \dot{D} \\
\stackrel{D}{\ominus} & +\end{array}$ & $\begin{array}{ll}0 & 1 \\
\dot{0} & 0 \\
\hat{1} & 0 \\
0 & 0\end{array}$ & $\begin{array}{ll}0 & \dot{0} \\
\stackrel{N}{N} & \dot{0} \\
\end{array}$ & 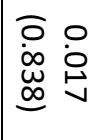 & $\mid \begin{array}{ll}0 & 0 \\
\dot{D} & 0 \\
0 & 0 \\
& 0 \\
0\end{array}$ & 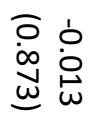 & $\begin{array}{ll}0 & 0 \\
\text { i⿱ } & 0 \\
\text { ปे } & 0\end{array}$ & 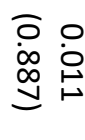 \\
\hline $\begin{array}{c}\text { Aphelocoma } \\
\text { californica } \\
\text { (Western Scrub-Jay) }\end{array}$ & 穴 & $\begin{array}{ll}0 & 0 \\
\text { in } & 0 \\
\tilde{N} & 0 \\
0 & N\end{array}$ & 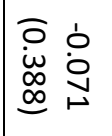 & 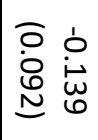 & $\begin{array}{ll}0 & 1 \\
\dot{0} & 0 \\
0 & 0 \\
0 & N\end{array}$ & 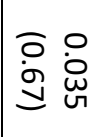 & $\begin{array}{ll}0 & 0 \\
\dot{w} & 0 \\
0 & 0 \\
\doteq & 0\end{array}$ & 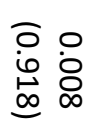 & 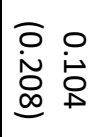 & $\begin{array}{l}\overline{0} \\
\dot{0} \\
\dot{\omega} \\
\underline{\omega}\end{array}$ \\
\hline
\end{tabular}




\begin{tabular}{|c|c|c|c|c|c|c|c|c|c|c|}
\hline $\begin{array}{l}\text { Columba livia } \\
\text { (Rock Pigeon) }\end{array}$ & 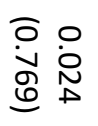 & $\begin{array}{ll}\overline{0} & 0 \\
\dot{0} & 0 \\
0 & 0 \\
\omega & 0 \\
0\end{array}$ & 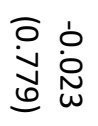 & 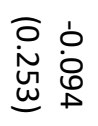 & 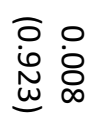 & 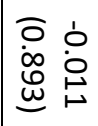 & $\begin{array}{ll} & 0 \\
0 & 0 \\
0 & 0 \\
\text { Oे } & 0 \\
0 & 1\end{array}$ & $\begin{array}{ll} & 0 \\
0 & 0 \\
0 & 0 \\
\text { v } & 0\end{array}$ & 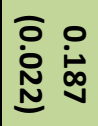 & $\begin{array}{ll} & 0 \\
0 & 0 \\
0 & 0 \\
0 & 0 \\
\omega & 0\end{array}$ \\
\hline $\begin{array}{c}\text { Passer domesticus } \\
\text { (House Sparrow) }\end{array}$ & 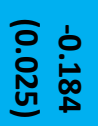 & $\begin{array}{ll} & 0 \\
\dot{P} & 0 \\
\dot{H} & : \\
& 0\end{array}$ & 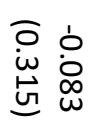 & 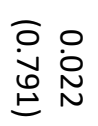 & $\begin{array}{ll} & 0 \\
0 & 0 \\
0 & 0 \\
0 & 0 \\
0 & 0\end{array}$ & $\begin{array}{ll}0 & 1 \\
\dot{0} & 0 \\
0 & 0 \\
\omega & 0 \\
\omega\end{array}$ & 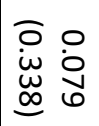 & 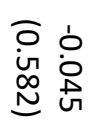 & $\begin{array}{ll} & 0 \\
\dot{N} & 0 \\
N & \dot{8} \\
& 0\end{array}$ & 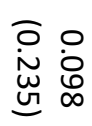 \\
\hline $\begin{array}{l}\text { European Starling } \\
\text { (Sturnus vulgaris) }\end{array}$ & $\begin{array}{ll} & 0 \\
0 & 0 \\
\dot{0} & 0 \\
0 & 0 \\
0\end{array}$ & 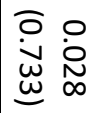 & 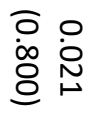 & $\begin{array}{l}\partial \dot{0} \\
\dot{0} \\
\dot{0} \\
\underline{\omega}\end{array}$ & 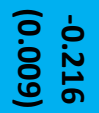 & $\begin{array}{ll}0 & 0 \\
0 & 0 \\
0 & 0 \\
0 & 0 \\
0\end{array}$ & 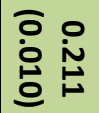 & 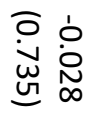 & $\mid \begin{array}{ll}0 & 1 \\
\dot{\omega} & 0 \\
\text { ô } & 0 \\
0 & \sigma\end{array}$ & 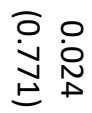 \\
\hline
\end{tabular}




\section{Chapter 3 References}

Aldrich JW and Coffin RW. 1980. "Breeding bird populations from forest to suburbia after 37 years." American Birds 34: 3-7.

Andersen, Alan N. 1993. "Ants as Indicators of Restoration Success at a Uranium Mine in Tropical Australia." Restoration Ecology 1 (3):156-67. https://doi.org/10.1111/i.1526-100X.1993.tb00022.x.

Baker, Philip J., and Stephen Harris. 2007. “Urban Mammals: What Does the Future Hold? An Analysis of the Factors Affecting Patterns of Use of Residential Gardens in Great Britain." Mammal Review 37 (4):297-315. https://doi.org/10.1111/i.1365-2907.2007.00102.x.

Blair, Robert. 2004. "The Effects of Urban Sprawl on Birds at Multiple Levels of Biological Organization." Ecology and Society 9 (5). https://doi.org/10.5751/ES-00688$\underline{090502 .}$.

Bormann, F. Herbert, Diana Balmori, and Gordon T. Geballe. 2001. Redesigning the American Lawn: A Search for Environmental Harmony. Yale University Press.

Braman, S. K., J. G. Latimer, R. D. Oetting, R. D. McQueen, T. B. Eckberg, and M. Prinster. 2000. "Management Strategy, Shade, and Landscape Composition Effects on Urban Landscape Plant Quality and Arthropod Abundance." Journal of Economic Entomology 93 (5):1464-72. https://doi.org/10.1603/0022-0493-93.5.1464.

Brown, M. W, and Thomas Tworkoski. 2004. "Pest Management Benefits of Compost Mulch in Apple Orchards." Agriculture, Ecosystems and Environment 103 (3):46572. https://doi.org/10.1016/i.agee.2003.11.006.

Brumm, Henrik. 2004. "The Impact of Environmental Noise on Song Amplitude in a Territorial Bird." Journal of Animal Ecology 73 (3):434-40. https://doi.org/10.1111/i.0021-8790.2004.00814.x.

Burghardt, Karin T., Douglas W. Tallamy, and W. Gregory Shriver. 2009. "Impact of Native Plants on Bird and Butterfly Biodiversity in Suburban Landscapes." Conservation Biology 23 (1):219-24. https://doi.org/10.1111/i.15231739.2008.01076.x. 
Carbó-Ramírez, Pilar, and Iriana Zuria. 2011. "The Value of Small Urban Greenspaces for Birds in a Mexican City." Landscape and Urban Planning 100 (3):213-22. https://doi.org/10.1016/i.landurbplan.2010.12.008.

Chace, Jameson F., and John J. Walsh. 2006. "Urban Effects on Native Avifauna: A Review." Landscape and Urban Planning 74 (1):46-69. https://doi.org/10.1016/i.landurbplan.2004.08.007.

Croci, Solène, Alain Butet, and Philippe Clergeau. 2008. "Does Urbanization Filter Birds on the Basis of Their Biological Traits." The Condor 110 (2):223-40. https://doi.org/10.1525/cond.2008.8409.

Daniels, G. D., and J. B. Kirkpatrick. 2006. "Does Variation in Garden Characteristics Influence the Conservation of Birds in Suburbia?" Biological Conservation 133 (3):326-35. https://doi.org/10.1016/i.biocon.2006.06.011.

Davis, Stephen K., and M. Brittingham. 2004. "Area Sensitivity in Grassland Passerines: Effects of Patch Size, Patch Shape, and Vegetation Structure on Bird Abundance and Occurrence in Southern Saskatchewan." The Auk 121 (4):1130-45. https://doi.org/10.1642/0004-8038(2004)121[1130:ASIGPE]2.0.CO;2.

Evans, Karl L., Stuart E. Newson, and Kevin J. Gaston. 2009. "Habitat Influences on Urban Avian Assemblages." Ibis 151 (1):19-39. https://doi.org/10.1111/j.1474919X.2008.00898.x.

Faeth, Stanley H., Christofer Bang, and Susanna Saari. 2011. "Urban Biodiversity: Patterns and Mechanisms." Annals of the New York Academy of Sciences 1223 (1):69-81. https://doi.org/10.1111/j.1749-6632.2010.05925.x.

Fernández-Juricic, Esteban, and Jukka Jokimäki. 2001. “A Habitat Island Approach to Conserving Birds in Urban Landscapes: Case Studies from Southern and Northern Europe." Biodiversity and Conservation 10 (12):2023-43. https://doi.org/10.1023/A:1013133308987.

Frank, Daniel L., and Oscar E. Liburd. 2005. "Effects of Living and Synthetic Mulch on the Population Dynamics of Whiteflies and Aphids, Their Associated Natural Enemies, and Insect-Transmitted Plant Diseases in Zucchini." Environmental Entomology 34 (4):857-65. https://doi.org/10.1603/0046-225X-34.4.857.

Fuller, Richard A., Philip H. Warren, Paul R. Armsworth, Olga Barbosa, and Kevin J. Gaston. 2008. "Garden Bird Feeding Predicts the Structure of Urban Avian Assemblages." Diversity and Distributions 14 (1):131-37. https://doi.org/10.1111/j.1472-4642.2007.00439.x. 
Gavareski, Carol A. 1976. "Relation of Park Size and Vegetation to Urban Bird Populations in Seattle, Washington." The Condor 78 (3):375-82. https://doi.org/10.2307/1367699.

Gibbs, Andrew Chapter 2 2018. "The efficacy of Portland Audubon's Backyard Certification Program at creating natural habitat."

Gibbs, Andrew Chapter 3 2018. "The Ability of the Backyard Habitat Certification Program, Certified Habitat Yards, to Support the Avian Community of Portland Oregon."

Goddard, Mark A., Andrew J. Dougill, and Tim G. Benton. 2010. "Scaling up from Gardens: Biodiversity Conservation in Urban Environments." Trends in Ecology and Evolution 25 (2):90-98. https://doi.org/10.1016/i.tree.2009.07.016.

Halfwerk, Wouter, Leonard J. M. Holleman, C(Kate). M. Lessells, and Hans Slabbekoorn. 2011. "Negative Impact of Traffic Noise on Avian Reproductive Success." Journal of Applied Ecology 48 (1):210-19. https://doi.org/10.1111/j.13652664.2010.01914.x.

Heezik, Yolanda van, and Amy Louise Adams. 2016. "Vulnerability of Native and Exotic Urban Birds to Housing Densification and Changing Gardening and Landscaping Trends." Urban Ecosystems 19 (4):1551-63. https://doi.org/10.1007/s11252-0140379-7.

Hennings, Lori A., and W. Daniel Edge. 2003. "Riparian Bird Community Structure in Portland, Oregon: Habitat, Urbanization, and Spatial Scale Patterns." The Condor 105 (2):288-302. https://doi.org/10.1650/00105422(2003)105[0288:RBCSIP]2.0.CO;2.

Hobbs, Richard J., and David A. Norton. 1996. "Towards a Conceptual Framework for Restoration Ecology." Restoration Ecology 4 (2):93-110. https://doi.org/10.1111/i.1526-100X.1996.tb00112.x.

Jolliffe, Ian T., and Jorge Cadima. 2016. "Principal Component Analysis: A Review and Recent Developments." Philosophical Transactions. Series A, Mathematical, Physical, and Engineering Sciences 374 (2065). https://doi.org/10.1098/rsta.2015.0202.

Jones, Elizabeth L., and Simon R. Leather. 2012. "Invertebrates in Urban Areas: A Review." European Journal of Entomology 109 (4):463-78. 
Lerman, Susannah B., and Paige S. Warren. 2011. "The Conservation Value of Residential Yards: Linking Birds and People." Ecological Applications 21 (4):1327-39. https://doi.org/10.1890/10-0423.1.

Leston, Lionel F. V., and Amanda D. Rodewald. 2006. "Are Urban Forests Ecological Traps for Understory Birds? An Examination Using Northern Cardinals." Biological Conservation 131 (4):566-74. https://doi.org/10.1016/i.biocon.2006.03.003.

Lomov, Boris, David A. Keith, and Dieter F. Hochuli. 2009. "Linking Ecological Function to Species Composition in Ecological Restoration: Seed Removal by Ants in Recreated Woodland." Austral Ecology 34 (7):751-60. https://doi.org/10.1111/j.1442-9993.2009.01981.x.

Longcore, Travis. 2003. "Terrestrial Arthropods as Indicators of Ecological Restoration Success in Coastal Sage Scrub (California, U.S.A.)." Restoration Ecology 11 (4):397-409. https://doi.org/10.1046/j.1526-100X.2003.rec0221.x.

Martin, Leanne M., Kirk A. Moloney, and Brian J. Wilsey. 2005. "An Assessment of Grassland Restoration Success Using Species Diversity Components." Journal of Applied Ecology 42 (2):327-36. https://doi.org/10.1111/i.13652664.2005.01019.x.

Marzluff, John M. 2001. "Worldwide Urbanization and Its Effects on Birds." In Avian Ecology and Conservation in an Urbanizing World, 19-47. Springer, Boston, MA. https://doi.org/10.1007/978-1-4615-1531-9 2.

Marzluff, John M., and Kern Ewing. 2001. "Restoration of Fragmented Landscapes for the Conservation of Birds: A General Framework and Specific Recommendations for Urbanizing Landscapes." Restoration Ecology 9 (3):280-92. https://doi.org/10.1046/j.1526-100x.2001.009003280.x.

McClure, H. Elliott. 1989. "What Characterizes an Urban Bird?” Journal of the Yamashina Institute for Ornithology 21 (2):178-92. https://doi.org/10.3312/ivio1952.21.178.

McIntyre, N. E., J. Rango, W. F. Fagan, and S. H. Faeth. 2001. "Ground Arthropod Community Structure in a Heterogeneous Urban Environment." Landscape and Urban Planning 52 (4):257-74. https://doi.org/10.1016/S0169-2046(00)00122-5.

Melles, S.J., Susan M. Glenn, and Kathy Martin. 2003. “Urban Bird Diversity and Landscape Complexity: Species-Environment Associations Along a Multiscale Habitat Gradient." Conservation Ecology 7 (June). https://doi.org/10.5751/ES00478-070105. 
Mills, G. Scott, John B. Dunning, and John M. Bates. 1989. "Effects of Urbanization on Breeding Bird Community Structure in Southwestern Desert Habitats." The Condor 91 (2):416-28. https://doi.org/10.2307/1368320.

Mills, G. Scott, John B. Dunning, and John M. Bates. 1991. "The Relationship between Breeding Bird Density and Vegetation Volume." The Wilson Bulletin 103 (3): 46879.

“ODFW Ocean Salmon Regulations." n.d. Accessed November 16, 2017. http://www.dfw.state.or.us/mrp/salmon/Regulations/regindex.asp.

"Oregon Secretary of State: Oregon Environmental Legislation." n.d. Accessed November 15, 2017.

http://sos.oregon.gov/archives/exhibits/highlights/Pages/environment.aspx.

Ortega-Álvarez, Rubén, and lan MacGregor-Fors. 2009. "Living in the Big City: Effects of Urban Land-Use on Bird Community Structure, Diversity, and Composition." Landscape and Urban Planning 90 (3):189-95. https://doi.org/10.1016/j.landurbplan.2008.11.003.

Palomino, David, and Luis M. Carrascal. 2006. "Urban Influence on Birds at a Regional Scale: A Case Study with the Avifauna of Northern Madrid Province." Landscape and Urban Planning 77 (3):276-90. https://doi.org/10.1016/i.landurbplan.2005.04.003.

Parris, Kirsten, and Angela Schneider. 2009. "Impacts of Traffic Noise and Traffic Volume on Birds of Roadside Habitats." Ecology and Society 14 (1). https://doi.org/10.5751/ES-02761-140129.

Portland Metro Regional Government. 2014. "Canopy 2014". http://rlisdiscovery.oregonmetro.gov/?resourcelD=99.

Portland Oregon 2016 1. "Neighborhood Greenways." https://www.portlandoregon.gov/transportation/50518.

Robel, R. J., J. N. Briggs, A. D. Dayton, and L. C. Hulbert. 1970. "Relationships between Visual Obstruction Measurements and Weight of Grassland Vegetation." Journal of Range Management 23 (4):295-97. https://doi.org/10.2307/3896225.

Rodewald, Amanda D., Daniel P. Shustack, and Lauren E. Hitchcock. 2010. "Exotic Shrubs as Ephemeral Ecological Traps for Nesting Birds." Biological Invasions 12 (1):3339. https://doi.org/10.1007/s10530-009-9426-3. 
Ruiz-Jaén, María C., and T. Mitchell Aide. 2005. "Vegetation Structure, Species Diversity, and Ecosystem Processes as Measures of Restoration Success." Forest Ecology and Management 218 (1):159-73. https://doi.org/10.1016/j.foreco.2005.07.008.

Sandström, U. G., P. Angelstam, and G. Mikusiński. 2006. "Ecological Diversity of Birds in Relation to the Structure of Urban Green Space." Landscape and Urban Planning 77 (1):39-53. https://doi.org/10.1016/i.landurbplan.2005.01.004.

Schmidt, Kenneth A., and Christopher J. Whelan. 1999. "Effects of Exotic Lonicera and Rhamnus on Songbird Nest Predation." Conservation Biology 13 (6):1502-6. https://doi.org/10.1046/i.1523-1739.1999.99050.x.

Sridhar, Hari, Guy Beauchamp, and Kartik Shanker. 2009. "Why Do Birds Participate in Mixed-Species Foraging Flocks? A Large-Scale Synthesis." Animal Behaviour 78 (2):337-47. https://doi.org/10.1016/j.anbehav.2009.05.008.

State of Oregon. 2017. Department of Environmental Quality. http://www.oregon.gov/DEQ/pages/index.aspx.

State of Oregon. 2017. "Oregon Department of Forestry - Laws and Rules." Accessed November 16, 2017. http://www.oregon.gov/ODF/Pages/LawsRules.aspx.

Tews, J., U. Brose, V. Grimm, K. Tielbörger, M. C. Wichmann, M. Schwager, and F. Jeltsch. 2004. "Animal Species Diversity Driven by Habitat Heterogeneity/Diversity: The Importance of Keystone Structures." Journal of Biogeography 31 (1):79-92. https://doi.org/10.1046/i.0305-0270.2003.00994.x.

Tilghman, Nancy G. 1987. "Characteristics of Urban Woodlands Affecting Breeding Bird Diversity and Abundance." Landscape and Urban Planning 14 (Supplement C):481-95. https://doi.org/10.1016/0169-2046(87)90061-2.

Portland Oregon. 2016. "Urban Forest Management Plan”. The City of Portland, Oregon. Accessed November 16, 2017. https://www.portlandoregon.gov/parks/60402.

United States Environmental Protection Agency. 2015. “EnviroAtlas Community Data." ftp://newftp.epa.gov/epadatacommons/ORD/EnviroAtlas/POR_Landcover_tif.zip

United States Environmental Protection Agency. 2013. "Summary of the Clean Water Act." Overviews and Factsheets. US EPA. February 22, 2013. https://www.epa.gov/laws-regulations/summary-clean-water-act. 
United States Environmental Protection Agency.2015. "Clean Air Act Text." Collections and Lists. US EPA. May 29, 2015. https://www.epa.gov/clean-air-actoverview/clean-air-act-text.

United States Fish and Wildlife Service. 2013. "Endangered Species Program, Laws and Policies, Endangered Species Act." Accessed November 16, 2017. https://www.fws.gov/endangered/laws-policies/esa.html.

Vine, Ian. 1971. "Risk of Visual Detection and Pursuit by a Predator and the Selective Advantage of Flocking Behaviour." Journal of Theoretical Biology 30 (2):405-22. https://doi.org/10.1016/0022-5193(71)90061-0.

Wallace, K. J., Daniel C. Laughlin, and Bruce D. Clarkson. 2017. “Exotic Weeds and Fluctuating Microclimate Can Constrain Native Plant Regeneration in Urban Forest Restoration." Ecological Applications 27 (4): 1268-79. https://doi.org/10.1002/eap.1520.

Wortley, Liana, Jean-Marc Hero, and Michael Howes. 2013. "Evaluating Ecological Restoration Success: A Review of the Literature." Restoration Ecology 21 (5): 537-43. https://doi.org/10.1111/rec.12028.

Werner, Peter. 2011. "The Ecology of Urban Areas and Their Functions for Species Diversity." Landscape and Ecological Engineering 7 (2):231-40. https://doi.org/10.1007/s11355-011-0153-4. 


\section{Appendix A}

\section{Chapter 1 Appendix Tables and Figures}

\begin{tabular}{|c|c|c|}
\hline \multicolumn{3}{|c|}{$\begin{array}{l}\text { Appendix A Table } 1 \text { Addresses of } 73 \text { random locations used in this study. } \\
\text { Location IDs are unique identifiers used for tracking data. Region is of } \\
\text { Portland Oregon, there are } 5, \mathrm{~N}, \mathrm{NE}, \mathrm{SE}, \mathrm{SW} \text {. }\end{array}$} \\
\hline $\begin{array}{l}\text { Location } \\
\text { ID }\end{array}$ & Site Address & Region \\
\hline 203 & 8137 Southeast 86th Avenue Portland OR 97266 & SE \\
\hline 204 & $\begin{array}{l}9242 \text { Northeast Hancock Drive Portland OR } \\
97220\end{array}$ & NE \\
\hline 205 & 4867 North Basin Avenue Portland OR 97217 & $\mathrm{~N}$ \\
\hline 207 & 3719 Southwest Hillside Drive Portland OR 97221 & SE \\
\hline 208 & $\begin{array}{l}2182 \text { Southeast Hanna Harvester Drive Milwaukie } \\
\text { OR } 97222\end{array}$ & SE \\
\hline 209 & 1000 NW 53rd Drive Portland OR 97210 & NW \\
\hline 210 & 339 Northwest 12th Avenue Portland OR 97209 & NW \\
\hline 211 & 403 SE 136th Ave Portland OR 97233 & SE \\
\hline 212 & 12031 North Burgard Road Portland OR 97203 & $\mathrm{~N}$ \\
\hline 213 & 1798 NE 56th Ave Portland OR 97213 & $\mathrm{NE}$ \\
\hline 214 & $\begin{array}{l}17000 \text { Northeast Marine Drive Portland OR } \\
97230\end{array}$ & NE \\
\hline 215 & 9878 North Whitaker Road Portland OR 97217 & $\mathrm{~N}$ \\
\hline 216 & 4956 Bilford LN Lake Oswego OR 97035 & SW \\
\hline 217 & 16834 Southeast Foster Road Gresham OR 97080 & SE \\
\hline 218 & 6325 NE 34th Ave Portland OR 97211 & $\mathrm{NE}$ \\
\hline 219 & 611 SW Nevada Street Portland OR 97219 & SW \\
\hline 220 & 1651 SW Birdsdale Ct Gresham OR 97080 & SW \\
\hline 222 & 5073 NE 138th Ave Portland OR 97230 & NE \\
\hline 223 & 2114 SW Marigold St Portland OR 97219 & SW \\
\hline 224 & 3272 Northeast 148th Avenue Portland OR 97230 & $\mathrm{NE}$ \\
\hline 225 & 6317 NE Emerson St Portland OR 97218 & NE \\
\hline 226 & 19 Monticello Drive Lake Oswego OR 97035 & SW \\
\hline 227 & 2735 SE 166th Ave Portland OR 97236 & SE \\
\hline 228 & 8353 SE Aspen Summit Drive Portland OR 97266 & SE \\
\hline 229 & 8869 SW Spruce St Tigard OR 97223 & SW \\
\hline 230 & 1126 Southeast 73rd Avenue Portland OR 97215 & SE \\
\hline 231 & 16396 NE Cameron Blvd Portland OR 97230 & NE \\
\hline 233 & 3088 SW Fairmont Blvd Portland OR 97239 & SW \\
\hline 234 & 808 SE 209th Ave. Gresham OR 97030 & SE \\
\hline 236 & 3 Bernini Court Lake Oswego OR 97035 & SW \\
\hline
\end{tabular}

152 


\begin{tabular}{|c|c|c|}
\hline 237 & $\begin{array}{l}16440 \text { Northeast Mason Street Portland OR } \\
97230\end{array}$ & NE \\
\hline 239 & 217 Northeast 63rd Avenue Portland OR 97213 & NE \\
\hline 240 & 6433 Southeast 100th Avenue Portland OR 97266 & SE \\
\hline 241 & 6851 Southeast 115th Avenue Portland OR 97266 & SE \\
\hline 242 & 2608 North Winchell Street Portland OR 97217 & $\mathrm{~N}$ \\
\hline 243 & 7958 Southeast 141st Avenue Portland OR 97236 & SE \\
\hline 244 & 2911 NE 72nd Ave Portland OR 97213 & NE \\
\hline 245 & 4292 Southwest 52nd Avenue Portland OR 97221 & SW \\
\hline 246 & 3536 SE Harvey Milwaukie OR 97222 & SE \\
\hline 248 & 4530 Northeast Mason Street Portland OR 97218 & $\mathrm{NE}$ \\
\hline 249 & 5560 North Columbia Court Portland OR 97203 & $\mathrm{~N}$ \\
\hline 250 & 1603 Northwest 14th Avenue Portland OR 97209 & NW \\
\hline 251 & 3105 N Marine Dr Portland OR 97217 & $\mathrm{~N}$ \\
\hline 252 & 11318 Southwest 72nd Avenue Tigard OR 97223 & SW \\
\hline 253 & 8833 Southeast 9th Avenue Portland OR 97202 & SE \\
\hline 254 & $\begin{array}{l}4557 \text { Southeast Rhodesa Street Milwaukie OR } \\
97222\end{array}$ & SE \\
\hline 255 & 3006 Southeast 16th Street Gresham OR 97080 & SE \\
\hline 256 & 5800 NE Portland Hwy Portland OR 97218 & $\mathrm{NE}$ \\
\hline 257 & 5479 Southeast 47th Avenue Portland Or 97206 & SE \\
\hline 258 & $\begin{array}{l}7736 \text { Southeast Sunnyside Drive Portland OR } \\
97222\end{array}$ & SE \\
\hline 259 & 9617 North Smith Street Portland OR 97203 & $\mathrm{~N}$ \\
\hline 261 & 6015 Northeast 80th Avenue Portland OR 97218 & NE \\
\hline 263 & 6822 Southeast Henry Street Portland OR 97206 & SE \\
\hline 264 & 11342 Northeast Marx Place Portland OR 97220 & NE \\
\hline 265 & $\begin{array}{l}8189 \text { Northeast Air Cargo Road Portland OR } \\
97218\end{array}$ & $\mathrm{NE}$ \\
\hline 266 & $\begin{array}{l}2093 \text { Southwest Mount Hood Lane Portland OR } \\
97239\end{array}$ & SW \\
\hline 267 & 6403 SE Dunbar Drive Portland OR 97236 & SE \\
\hline 268 & 54 Centerpointe Drive Lake Oswego OR 97035 & SW \\
\hline 269 & $\begin{array}{l}9318 \text { North Charleston Avenue Portland OR } \\
97203\end{array}$ & $\mathrm{~N}$ \\
\hline 270 & $\begin{array}{l}2741 \text { Northwest Beuhla Vista Terrace Portland } \\
\text { OR } 97210\end{array}$ & NW \\
\hline 272 & 6335 Northeast 66th Avenue Portland OR 97218 & $\mathrm{NE}$ \\
\hline 273 & 1825 North Emerson Street Portland OR 97217 & $\mathrm{~N}$ \\
\hline 274 & $\begin{array}{l}4609 \text { Northeast Ainsworth Street Portland OR } \\
97218\end{array}$ & $\mathrm{NE}$ \\
\hline 276 & 8131 North Olympia Street Portland OR 97203 & $\mathrm{~N}$ \\
\hline 277 & 5433 North Channel Avenue Portland OR 97217 & $\mathrm{~N}$ \\
\hline
\end{tabular}




\begin{tabular}{|c|l|c|} 
& $\begin{array}{l}2621 \text { Northeast Hamblet Street Portland OR } \\
97212\end{array}$ & NE \\
\hline 278 & 1734 North Colfax Street Portland OR 97217 & N \\
\hline 280 & $\begin{array}{l}\text { 709 Northeast Roselawn Street Portland OR } \\
97211\end{array}$ & NE \\
\hline 281 & 5233 North Yale Street Portland OR 97203 & N \\
\hline 282 & 10108 North Macrum Avenue Portland OR 97203 & N \\
\hline 285 & 2718 Northeast 10th Avenue Portland OR 97212 & NE \\
\hline 287 & 1085 NE 52nd Ave Portland OR 97213 & NE \\
\hline 288 & 8111 N Crawford St Portland OR 97203 & N \\
\hline
\end{tabular}




\section{Appendix B}

\section{Chapter 2 Appendix Tables and Figures}

\begin{tabular}{|c|c|c|}
\hline \multicolumn{3}{|c|}{ Appendix B Table 1: Audubon Society or Portland (ASP) Backyard Habitat Certification Program } \\
\hline \multicolumn{3}{|c|}{ Gold, and Platinum. Compliance is verified with initial site inspections, as well as further inspections } \\
\hline \multirow{2}{*}{\multicolumn{3}{|c|}{ every three years for continued certification of program compliance. These criteria were copied }} \\
\hline & & \\
\hline \multicolumn{3}{|c|}{ Invasive Weeds (Prohibited) } \\
\hline Silver & Gold & Platinum \\
\hline $\begin{array}{l}\text { Evergreen and Armenian Blackberry } \\
\text { (Rubus laciniatus and Rubus } \\
\text { armeniacus) }\end{array}$ & $\begin{array}{l}\text { Butterfly Bush (Buddleia } \\
\text { davidii - all varieties) }\end{array}$ & $\begin{array}{l}\text { Creeping Jenny } \\
\text { (Lysimachia nummularia) }\end{array}$ \\
\hline Garlic Mustard (Alliaria petiolata) & $\begin{array}{l}\text { False Brome (Brachypodium } \\
\text { sylvaticum) }\end{array}$ & $\begin{array}{l}\text { English and Portuguese } \\
\text { Laurel (Prunus spp.) }\end{array}$ \\
\hline $\begin{array}{l}\text { Giant Hogweed (Heracleum } \\
\text { mantegazzianum) }\end{array}$ & $\begin{array}{l}\text { Hedge Bindweed (Calystegia } \\
\text { sepium) }\end{array}$ & Fennel (Foeniculum spp.) \\
\hline Ivy (all cultivars, Hedra spp.) & Italian Arum (Arum italicum) & $\begin{array}{l}\text { Large and Small-leaf } \\
\text { Periwinkle (Vinca spp.) }\end{array}$ \\
\hline Knotweed (Polygonum spp.) & $\begin{array}{l}\text { Japanese Butterbur (Petasites } \\
\text { japonica) }\end{array}$ & $\begin{array}{l}\text { Reed Canarygrass and } \\
\text { Ribbon Grass (Phalaris } \\
\text { arundinacea) }\end{array}$ \\
\hline $\begin{array}{l}\text { Orange Hawkweed (Hieracium } \\
\text { aurantiacum) }\end{array}$ & $\begin{array}{l}\text { Lesser Celandine (Ranunculus } \\
\text { ficaria) }\end{array}$ & \\
\hline Pokeweed (Phytolacca americana) & $\begin{array}{l}\text { Pampas and Jubata Grass } \\
\text { (Cortaderia ssp.) }\end{array}$ & \\
\hline $\begin{array}{l}\text { Policeman's Helmet (Impatiens } \\
\text { glandulifera) }\end{array}$ & $\begin{array}{l}\text { Robert Geranium (Geranium } \\
\text { robertianum) }\end{array}$ & \\
\hline Purple Loosestrife (Lythrum salicaria) & $\begin{array}{l}\text { Shining Geranium (Geranium } \\
\text { lucidum) }\end{array}$ & \\
\hline \multicolumn{3}{|l|}{ Scot's Broom (Cytisus scoparius) } \\
\hline $\begin{array}{l}\text { Spotted, Meadow and Diffuse } \\
\text { Knapweeds (Centaurea spp.) }\end{array}$ & $\begin{array}{l}\text { Invasive Trees - } \\
\text { under } 20 \mathrm{ft}\end{array}$ & $\begin{array}{l}\text { Invasive Trees - } \\
\text { over } 20 \mathrm{ft}\end{array}$ \\
\hline Spurge Laurel (Daphne laureola) & $\begin{array}{l}\text { Black Locust (Robinia } \\
\text { pseudoacacia) }\end{array}$ & $\begin{array}{l}\text { Black Locust (Robinia } \\
\text { pseudoacacia) }\end{array}$ \\
\hline Traveler's Joy (Clematis vitalba) & $\begin{array}{l}\text { English Hawthorn (Crataegus } \\
\text { monogyna) }\end{array}$ & $\begin{array}{l}\text { English Hawthorn } \\
\text { (Crataegus monogyna) }\end{array}$ \\
\hline $\begin{array}{l}\text { Yellow Archangel (Lamiastrum } \\
\text { galeoblodon) }\end{array}$ & English Holly (Ilex aquifolium) & $\begin{array}{l}\text { English Holly (Ilex } \\
\text { aquifolium) }\end{array}$ \\
\hline \multirow[t]{2}{*}{ Yellow Flag Iris (Iris pseudacorus) } & $\begin{array}{l}\text { Norway Maple (Acer } \\
\text { platanoides) }\end{array}$ & $\begin{array}{l}\text { Norway Maple (Acer } \\
\text { platanoides) }\end{array}$ \\
\hline & $\begin{array}{l}\text { Tree-of-Heaven (Ailanthus } \\
\text { altissima) }\end{array}$ & $\begin{array}{l}\text { Tree-of-Heaven (Ailanthus } \\
\text { altissima) }\end{array}$ \\
\hline
\end{tabular}




\begin{tabular}{|c|c|}
\hline \multicolumn{2}{|c|}{ Vegetation and Pesticides } \\
\hline Vegetation & Pesticides \\
\hline Silver & Silver \\
\hline $\begin{array}{l}\text { Naturescape at least } 5 \% \text { of available property } \\
\text { with locally native plants* }\end{array}$ & $\begin{array}{l}\text { Use only YELLOW or GREEN zone chemicals if } \\
\text { necessary, according to an IPM strategy }\end{array}$ \\
\hline Include at least 3 out of 5 vegetation levels & No use of RED zone chemicals \\
\hline Gold & Gold \\
\hline $\begin{array}{l}\text { Naturescape at least } 15 \% \text { of available property } \\
\text { with locally native plants* }\end{array}$ & $\begin{array}{l}\text { Use only GREEN zone chemicals if necessary, } \\
\text { according to an IPM strategy }\end{array}$ \\
\hline Include at least 4 out of 5 vegetation levels & No use of RED or YELLOW zone chemicals \\
\hline Platinum & Platinum \\
\hline $\begin{array}{l}\text { Naturescape at least } 50 \% \text { of available property } \\
\text { with locally native plants* }\end{array}$ & $\begin{array}{l}\text { Use only GREEN zone chemicals if necessary, } \\
\text { according to an IPM strategy }\end{array}$ \\
\hline \multirow[t]{2}{*}{ Include all 5 vegetation levels } & No use of RED or YELLOW zone chemicals \\
\hline & Take the Metro No Pesticides Pledge \\
\hline \multicolumn{2}{|l|}{ Vegetation Levels } \\
\hline A. Overstory Canopy & Storm Water Management \\
\hline \multirow[t]{2}{*}{$\begin{array}{l}30 \text { feet or higher I Examples: Oregon White Oak } \\
\text { or Western Red Cedar }\end{array}$} & Gold 1, Sliver 2, Platinum 3 of the following: \\
\hline & $\begin{array}{l}\text { Large canopy tree over } 30 \mathrm{ft} \text { (cannot be } \\
\text { nuisance species) }\end{array}$ \\
\hline B. Understory Canopy & Disconnected downspouts where appropriate \\
\hline \multirow[t]{2}{*}{$\begin{array}{l}\text { Less than } 30 \text { feet | Examples: Vine Maple or } \\
\text { Cascara }\end{array}$} & Raingardens, where appropriate \\
\hline & $\begin{array}{l}\text { Remove impervious surfaces and/or grass } 500 \mathrm{ft} \\
\text { or more }\end{array}$ \\
\hline C. Large Shrub Layer & Ecoroof according to City specifications \\
\hline \multirow[t]{2}{*}{$\begin{array}{l}5 \text { to } 20 \text { feet I Examples: Indian Plum or } \\
\text { Serviceberry }\end{array}$} & $\begin{array}{l}\text { Increase naturescaping } 10 \% \text { higher than your } \\
\text { certification level requirement }\end{array}$ \\
\hline & Restore soils (i.e. leave the leaves) \\
\hline D. Small/Medium Shrub Layer & $\begin{array}{l}\text { Water conservation (i.e. eliminating lawn } \\
\text { irrigation, water in morning and evening only) }\end{array}$ \\
\hline Less than 5 feet | Examples: Salal or native ferns & $\begin{array}{l}\text { Adopt eco-friendly maintenance practicies (i.e. } \\
\text { petroleum-free yard care, use landscapers from } \\
\text { Backyard Landscape Directory) }\end{array}$ \\
\hline \multicolumn{2}{|l|}{ E. Ground Layer } \\
\hline $\begin{array}{l}\text { Examples: Inside-out flower or Western Red } \\
\text { Columbine }\end{array}$ & \\
\hline
\end{tabular}




\begin{tabular}{|l|l|}
\hline \multicolumn{2}{|c|}{ Wildlife Stewardship; Education and Volunteerism } \\
\hline Wildlife Stewardship & Education and Volunteerism \\
\hline Silver 1, Gold 2, Platinum $\mathbf{3}$ of the following: & Gold and Silver: Optional, Platinum At least 1 \\
\hline $\begin{array}{l}\text { Wildlife water feature (natural source, } \\
\text { maintained bird or bug bath) }\end{array}$ & Recruit 2 neighbors to signup! \\
\hline $\begin{array}{l}\text { Cats indoors at all times or in an outdoor } \\
\text { enclosure }\end{array}$ & Allow site to be showcased in a yard tour \\
\hline $\begin{array}{l}\text { Bird or bat nest boxes (appropriate to native } \\
\text { species) }\end{array}$ & $\begin{array}{l}\text { Volunteer for the Backyard Habitat Certification } \\
\text { Program }\end{array}$ \\
\hline $\begin{array}{l}\text { Pollinator and beneficial insect nesting habitat } \\
\text { (i.e. rock piles, bundles of stems and branches, } \\
\text { mason bee house) }\end{array}$ & $\begin{array}{l}\text { Attend continuing education classes (i.e. EDRR } \\
\text { Weed Watcher) }\end{array}$ \\
\hline $\begin{array}{l}\text { Snag or nurse log } \\
\text { Reduce outdoor lighting during bird migration } \\
\text { (March-May, Sept-Nov) }\end{array}$ & $\begin{array}{l}\text { Participate in OSU Extension Master Gardener } \\
\text { Programs }\end{array}$ \\
\hline Reduce bird window collisions & \\
\hline $\begin{array}{l}\text { Native pollinator meadow which bloom through } \\
\text { the growing season }\end{array}$ & \\
\hline
\end{tabular}

\begin{tabular}{|l|l|l|}
\hline Appendix B Figure 1: Audubon Society or Portland (ASP) Backyard Habitat \\
Certification Program (BHCP) vegetation layer definitions. These definitions were \\
copied from the PAS website in 2016, and are publically available.
\end{tabular}




\begin{tabular}{|c|c|c|c|c|c|c|c|}
\hline \multicolumn{8}{|c|}{$\begin{array}{l}\text { Appendix B Table 2: Re } \\
\text { several ANOVAs. Each } \\
\text { each region, and all ya } \\
\text { consideration of certifi } \\
\text { error. For any significa } \\
\text { full model including all } \\
\text { rare (1 or fewer sites) } \\
\text { shown as }<0.00 \text {. }\end{array}$} \\
\hline & \multirow{2}{*}{ NP } & \multirow{2}{*}{$\mathrm{NE}$} & \multirow{2}{*}{ NW } & \multirow{2}{*}{ SE } & \multirow{2}{*}{ SW } & \multicolumn{2}{|c|}{ All Regions } \\
\hline & & & & & & Mean & $(F[P])$ \\
\hline Variable & \multicolumn{7}{|c|}{ Not Certified } \\
\hline $\begin{array}{l}\text { Bare } \\
\text { Ground }\end{array}$ & $\begin{array}{l}7.34 \pm \\
3.59\end{array}$ & $\begin{array}{l}11.98 \pm \\
4.02\end{array}$ & $\begin{array}{l}11.5 \pm \\
8.03\end{array}$ & $\begin{array}{l}11.25 \pm \\
2.07\end{array}$ & $\begin{array}{l}11.44 \pm \\
1.75\end{array}$ & 10.98 & $\begin{array}{c}0.29 \\
(0.88)\end{array}$ \\
\hline Stone & $\begin{array}{l}4.15 \pm \\
2.28\end{array}$ & $\begin{array}{l}1.05 \pm \\
2.54\end{array}$ & $8 \pm 5.09$ & $\begin{array}{l}3.7 \pm \\
1.31 \\
\end{array}$ & $\begin{array}{l}4.09 \pm \\
1.11 \\
\end{array}$ & 3.79 & $\begin{array}{c}0.49 \\
(0.75) \\
\end{array}$ \\
\hline Stump & $\begin{array}{l}0.33 \pm \\
0.14 \\
\end{array}$ & $\begin{array}{l}0.11 \pm \\
0.16 \\
\end{array}$ & $\begin{array}{l}<0.00 \pm \\
0.32\end{array}$ & $\begin{array}{l}<0.00 \pm \\
0.08\end{array}$ & $\begin{array}{l}0.1 \pm \\
0.07\end{array}$ & 0.09 & $\begin{array}{c}1.05 \\
(0.39) \\
\end{array}$ \\
\hline Tree Base & $\begin{array}{l}0.12 \pm \\
0.3\end{array}$ & $\begin{array}{l}0.28 \pm \\
0.15 \\
\end{array}$ & $\begin{array}{l}<0.00 \pm \\
0.29\end{array}$ & $\begin{array}{l}0.03 \pm \\
0.07 \\
\end{array}$ & $\begin{array}{l}0.13 \pm \\
0.06 \\
\end{array}$ & 0.09 & $\begin{array}{c}0.87 \\
(0.49) \\
\end{array}$ \\
\hline Fine Litter & $\begin{array}{l}30.03 \pm \\
8.38\end{array}$ & $\begin{array}{l}36.16 \pm \\
9.36\end{array}$ & $\begin{array}{l}28.4 \pm \\
18.73\end{array}$ & $\begin{array}{l}37.32 \pm \\
4.84\end{array}$ & $\begin{array}{l}45.6 \pm \\
4.09\end{array}$ & 40.01 & $\begin{array}{c}1.04 \\
(0.40)\end{array}$ \\
\hline Moss & $\begin{array}{l}2.95 \pm \\
4.56\end{array}$ & $\begin{array}{l}13.34 \pm \\
5.09\end{array}$ & $\begin{array}{l}16.2 \pm \\
10.19 \\
\end{array}$ & $\begin{array}{l}6.1 \pm \\
2.63 \\
\end{array}$ & $\begin{array}{l}11.45 \pm \\
2.22\end{array}$ & 9.05 & $\begin{array}{c}1.36 \\
(0.27) \\
\end{array}$ \\
\hline Lichen & $\begin{array}{l}<0.00 \pm \\
0.25\end{array}$ & $\begin{array}{l}0.21 \pm \\
0.28 \\
\end{array}$ & $\begin{array}{l}<0.00 \pm \\
0.55\end{array}$ & $\begin{array}{l}0.28 \pm \\
0.14 \\
\end{array}$ & $\begin{array}{l}0.03 \pm \\
0.12 \\
\end{array}$ & 0.12 & $\begin{array}{c}0.54 \\
(0.71) \\
\end{array}$ \\
\hline Lawn & $\begin{array}{l}47.19 \pm \\
9.18 \\
\end{array}$ & $\begin{array}{l}29.08 \pm \\
10.27 \\
\end{array}$ & $\begin{array}{l}35.2 \pm \\
20.53 \\
\end{array}$ & $\begin{array}{l}29.28 \pm \\
5.3\end{array}$ & $\begin{array}{l}20.53 \pm \\
4.48\end{array}$ & 27.34 & $\begin{array}{c}1.82 \\
(0.14) \\
\end{array}$ \\
\hline Mulch & $\begin{array}{l}13.73 \pm \\
8.7\end{array}$ & $\begin{array}{l}12.99 \pm \\
9.72 \\
\end{array}$ & $\begin{array}{l}<0.00 \pm \\
19.45\end{array}$ & $\begin{array}{l}15.46 \pm \\
5.02 \\
\end{array}$ & $\begin{array}{l}19.11 \pm \\
4.24\end{array}$ & 16.39 & $\begin{array}{c}0.34 \\
(0.85) \\
\end{array}$ \\
\hline $\begin{array}{l}\text { Herbaceou } \\
\mathrm{s}\end{array}$ & $\begin{array}{l}30.05 \pm \\
7.99 \\
\end{array}$ & $\begin{array}{l}31.62 \pm \\
8.93\end{array}$ & $\begin{array}{l}25 \pm \\
17.86 \\
\end{array}$ & $\begin{array}{l}35.94 \pm \\
4.61 \\
\end{array}$ & $\begin{array}{l}39.73 \pm \\
3.9\end{array}$ & 36.42 & $\begin{array}{c}0.52 \\
(0.72) \\
\end{array}$ \\
\hline Shrub & $\begin{array}{l}25.04 \pm \\
10.32 \\
\end{array}$ & $\begin{array}{l}26.46 \pm \\
11.53 \\
\end{array}$ & $\begin{array}{l}86.2 \pm \\
23.07 \\
\end{array}$ & $\begin{array}{l}35.52 \pm \\
5.96\end{array}$ & $\begin{array}{l}36.12 \pm \\
5.03\end{array}$ & 34.97 & $\begin{array}{c}1.62 \\
(0.19) \\
\end{array}$ \\
\hline Tree & $\begin{array}{l}28.38 \pm \\
7.4\end{array}$ & $\begin{array}{l}40.94 \pm \\
8.27\end{array}$ & $\begin{array}{l}21.5 \pm \\
16.55 \\
\end{array}$ & $\begin{array}{l}28.92 \pm \\
4.27\end{array}$ & $\begin{array}{l}37.12 \pm \\
3.61\end{array}$ & 33.49 & $\begin{array}{c}0.99 \\
(0.42) \\
\end{array}$ \\
\hline Exotic Herb & $\begin{array}{l}11.88 \pm \\
6.61\end{array}$ & $\begin{array}{l}25.93 \pm \\
7.39\end{array}$ & $\begin{array}{l}25.9 \pm \\
14.78\end{array}$ & $\begin{array}{l}20.17 \pm \\
3.82\end{array}$ & $\begin{array}{l}28.48 \pm \\
3.22\end{array}$ & 23.69 & $\begin{array}{c}1.59 \\
(0.19)\end{array}$ \\
\hline
\end{tabular}




\begin{tabular}{|c|c|c|c|c|c|c|c|}
\hline $\begin{array}{l}\text { Exotic } \\
\text { Shrub }\end{array}$ & $\begin{array}{l}9.53 \pm \\
7.21\end{array}$ & $\begin{array}{l}5.26 \pm \\
8.06\end{array}$ & $\begin{array}{l}26 \pm \\
16.12\end{array}$ & $\begin{array}{l}18.57 \pm \\
4.16\end{array}$ & $\begin{array}{l}15.96 \pm \\
3.52\end{array}$ & 15.4 & $\begin{array}{c}0.82 \\
(0.52)\end{array}$ \\
\hline Exotic Tree & $\begin{array}{l}17.95 \pm \\
5.34\end{array}$ & $\begin{array}{l}15.23 \pm \\
5.97\end{array}$ & $0 \pm 11.94$ & $\begin{array}{l}13.85 \pm \\
3.08\end{array}$ & $\begin{array}{l}17.92 \pm \\
2.6\end{array}$ & 15.97 & $\begin{array}{c}0.74 \\
(0.57) \\
\end{array}$ \\
\hline $\begin{array}{l}\text { Native } \\
\text { Herb }\end{array}$ & $\begin{array}{l}18.88 \pm \\
6.17\end{array}$ & $\begin{array}{l}5.26 \pm \\
6.9\end{array}$ & $0 \pm 13.8$ & $\begin{array}{l}17.82 \pm \\
3.56\end{array}$ & $\begin{array}{l}12.97 \pm \\
3.01\end{array}$ & 14.24 & $\begin{array}{c}1.13 \\
(0.36)\end{array}$ \\
\hline $\begin{array}{l}\text { Native } \\
\text { Shrub }\end{array}$ & $\begin{array}{l}15.17 \pm \\
8.25\end{array}$ & $\begin{array}{l}22.68 \pm \\
9.23\end{array}$ & $\begin{array}{l}60.2 \pm \\
18.45\end{array}$ & $\begin{array}{l}18.87 \pm \\
4.76\end{array}$ & $\begin{array}{l}20.35 \pm \\
4.03\end{array}$ & 20.37 & $\begin{array}{c}1.30 \\
(0.28)\end{array}$ \\
\hline Native Tree & $\begin{array}{l}9.97 \pm \\
6.07\end{array}$ & $\begin{array}{l}28.37 \pm \\
6.78\end{array}$ & $\begin{array}{l}21.5 \pm \\
13.57\end{array}$ & $\begin{array}{l}14.49 \pm \\
3.5\end{array}$ & $\begin{array}{l}21.78 \pm \\
2.96\end{array}$ & 18.69 & $\begin{array}{c}1.67 \\
(0.18)\end{array}$ \\
\hline & \multicolumn{7}{|c|}{ Silver } \\
\hline $\begin{array}{l}\text { Bare } \\
\text { Ground }\end{array}$ & $\begin{array}{l}7.19 \pm \\
2.38 \\
\end{array}$ & $31 \pm 9.2$ & $\begin{array}{l}<0.00 \pm \\
9.2\end{array}$ & $\begin{array}{l}9.33 \pm \\
2.66 \\
\end{array}$ & $\begin{array}{l}7.32 \pm \\
4.6 \\
\end{array}$ & 8.49 & $\begin{array}{c}1.83 \\
(0.15) \\
\end{array}$ \\
\hline Stone & $\begin{array}{l}7.54 \pm \\
2.22 \\
\end{array}$ & $\begin{array}{l}2.86 \pm \\
8.6 \\
\end{array}$ & $\begin{array}{l}17.5 \pm \\
8.6 \\
\end{array}$ & $\begin{array}{l}5.12 \pm \\
2.48 \\
\end{array}$ & $1.1 \pm 4.3$ & 6.04 & $\begin{array}{c}0.96 \\
(0.45) \\
\end{array}$ \\
\hline Stump & $\begin{array}{l}<0.00 \pm \\
0.01\end{array}$ & $\begin{array}{l}<0.00 \pm \\
0.05\end{array}$ & $\begin{array}{l}<0.00 \pm \\
0.05\end{array}$ & $\begin{array}{l}<0.00 \pm \\
0.01\end{array}$ & $\begin{array}{l}0.093 \pm \\
0.02 \\
(0.004)\end{array}$ & 0.01 & $\begin{array}{c}3.26 \\
(0.03)\end{array}$ \\
\hline Tree Base & $\begin{array}{l}0.15 \pm \\
0.1 \\
\end{array}$ & $\begin{array}{l}<0.00 \pm \\
0.37 \\
\end{array}$ & $\begin{array}{l}<0.00 \pm \\
0.37 \\
\end{array}$ & $\begin{array}{l}0.22 \pm \\
0.11 \\
\end{array}$ & $\begin{array}{l}0.27 \pm \\
0.19 \\
\end{array}$ & 0.18 & $\begin{array}{c}0.23 \\
(0.92) \\
\end{array}$ \\
\hline Fine Litter & $\begin{array}{l}23.21 \pm \\
4.44\end{array}$ & $\begin{array}{l}8.43 \pm \\
17.2\end{array}$ & $40 \pm 17.2$ & $\begin{array}{l}35.95 \pm \\
4.97\end{array}$ & $\begin{array}{l}45.23 \pm \\
8.6\end{array}$ & 30.57 & $\begin{array}{c}2.19 \\
(0.10)\end{array}$ \\
\hline Moss & $\begin{array}{l}3.09 \pm \\
1.46\end{array}$ & $\begin{array}{l}4.29 \pm \\
5.64\end{array}$ & $\begin{array}{l}<0.00 \pm \\
5.64\end{array}$ & $\begin{array}{l}2.86 \pm \\
1.63\end{array}$ & $\begin{array}{l}14.00 \pm \\
2.82 \\
(0.0029)\end{array}$ & 4.27 & $\begin{array}{c}3.47 \\
(0.02)\end{array}$ \\
\hline Lichen & $\begin{array}{l}0.3 \pm \\
0.17\end{array}$ & $\begin{array}{l}<0.00 \pm \\
0.66\end{array}$ & $\begin{array}{l}<0.00 \pm \\
0.66 \\
\end{array}$ & $\begin{array}{l}0.05 \pm \\
0.19 \\
\end{array}$ & $\begin{array}{l}0.03 \pm \\
0.33 \\
\end{array}$ & 0.16 & $\begin{array}{c}0.34 \\
(0.85) \\
\end{array}$ \\
\hline Lawn & $\begin{array}{l}20.77 \pm \\
4.62\end{array}$ & $\begin{array}{l}66.43 \pm \\
17.9 \\
(0.01)\end{array}$ & $\begin{array}{l}<0.00 \pm \\
17.9\end{array}$ & $\begin{array}{l}18.88 \pm \\
5.17\end{array}$ & $\begin{array}{l}24.49 \pm \\
8.95\end{array}$ & 21.29 & $\begin{array}{c}2.03 \\
(0.12)\end{array}$ \\
\hline Mulch & $\begin{array}{l}36.79 \pm \\
5.96 \\
\end{array}$ & $\begin{array}{l}66.43 \pm \\
23.09 \\
\end{array}$ & $\begin{array}{l}45 \pm \\
23.09 \\
\end{array}$ & $\begin{array}{l}28.5 \pm \\
6.66 \\
\end{array}$ & $\begin{array}{l}21.98 \pm \\
11.54 \\
\end{array}$ & 31.11 & $\begin{array}{c}0.97 \\
(0.44) \\
\end{array}$ \\
\hline $\begin{array}{l}\text { Herbaceou } \\
s\end{array}$ & $\begin{array}{l}38.12 \pm \\
4.23\end{array}$ & $\begin{array}{l}51.14 \pm \\
16.38\end{array}$ & $\begin{array}{l}42.5 \pm \\
16.38 \\
\end{array}$ & $\begin{array}{l}37.18 \pm \\
4.73 \\
\end{array}$ & $\begin{array}{l}25.67 \pm \\
8.19 \\
\end{array}$ & 36.8 & $\begin{array}{c}0.71 \\
(0.59) \\
\end{array}$ \\
\hline Shrub & $\begin{array}{l}32.17 \pm \\
4.68\end{array}$ & $\begin{array}{l}<0.00 \pm \\
18.11\end{array}$ & $\begin{array}{l}33.25 \pm \\
18.11\end{array}$ & $\begin{array}{l}41.66 \pm \\
5.23\end{array}$ & $\begin{array}{l}38.43 \pm \\
9.06\end{array}$ & 35.44 & $\begin{array}{c}1.46 \\
(0.24)\end{array}$ \\
\hline Tree & $\begin{array}{l}24.02 \pm \\
4.21 \\
(0.005)\end{array}$ & $\begin{array}{l}36.43 \pm \\
16.32\end{array}$ & $\begin{array}{l}81.75 \pm \\
16.32 \\
(0.008)\end{array}$ & $\begin{array}{l}27.56 \pm \\
4.71 \\
(0.023)\end{array}$ & $\begin{array}{l}42.88 \pm \\
8.16\end{array}$ & 29.72 & $\begin{array}{c}3.74 \\
(0.015)\end{array}$ \\
\hline Exotic Herb & $\begin{array}{l}26.14 \pm \\
3.61\end{array}$ & $\begin{array}{l}41.71 \pm \\
13.98\end{array}$ & $\begin{array}{l}23 \pm \\
13.98\end{array}$ & $\begin{array}{l}21.5 \pm \\
4.04\end{array}$ & $\begin{array}{l}16.24 \pm \\
6.99\end{array}$ & 23.63 & $\begin{array}{c}0.89 \\
(0.48)\end{array}$ \\
\hline $\begin{array}{l}\text { Exotic } \\
\text { Shrub }\end{array}$ & $\begin{array}{l}14.44 \pm \\
4.03 \\
\end{array}$ & $0 \pm 15.61$ & $\begin{array}{l}10.5 \pm \\
15.61 \\
\end{array}$ & $\begin{array}{l}17.29 \pm \\
4.51 \\
\end{array}$ & $\begin{array}{l}23.61 \pm \\
7.81 \\
\end{array}$ & 16.03 & $\begin{array}{c}0.59 \\
(0.67) \\
\end{array}$ \\
\hline Exotic Tree & $\begin{array}{l}16.93 \pm \\
4.26 \\
\end{array}$ & $\begin{array}{l}12.86 \pm \\
16.51 \\
\end{array}$ & $0 \pm 16.51$ & $\begin{array}{l}17.86 \pm \\
4.77 \\
\end{array}$ & $\begin{array}{l}8.79 \pm \\
8.25 \\
\end{array}$ & 15.64 & $\begin{array}{c}0.48 \\
(0.75) \\
\end{array}$ \\
\hline $\begin{array}{l}\text { Native } \\
\text { Herb }\end{array}$ & $\begin{array}{l}13.23 \pm \\
2.68\end{array}$ & 10.86 & $\begin{array}{l}14.5 \pm \\
10.39\end{array}$ & $16 \pm 3$ & $\begin{array}{l}12.07 \pm \\
5.19\end{array}$ & 14.06 & $\begin{array}{c}0.19 \\
(0.94)\end{array}$ \\
\hline
\end{tabular}




\begin{tabular}{|c|c|c|c|c|c|c|c|}
\hline $\begin{array}{l}\text { Native } \\
\text { Shrub }\end{array}$ & $\begin{array}{l}17.72 \pm \\
3.59\end{array}$ & $<0.00$ & $\begin{array}{l}21.25 \pm \\
13.89\end{array}$ & $\begin{array}{l}24.67 \pm \\
4.01\end{array}$ & $\begin{array}{l}17.11 \pm \\
6.94\end{array}$ & 19.74 & $\begin{array}{c}1.00 \\
(0.42)\end{array}$ \\
\hline Native Tree & $\begin{array}{l}7.64 \pm \\
3.52 \\
(0.0001) \\
\end{array}$ & 13.57 & $\begin{array}{l}81.75 \pm \\
13.63 \\
(0.0001) \\
\end{array}$ & $\begin{array}{l}10.14 \quad \pm \\
3.94 \\
(0.0008) \\
\end{array}$ & $\begin{array}{l}35.61 \pm \\
6.82\end{array}$ & 14.36 & $\begin{array}{c}9.74 \\
(<0.0001 \\
1 \\
\end{array}$ \\
\hline & \multicolumn{7}{|c|}{ Gold } \\
\hline $\begin{array}{l}\text { Bare } \\
\text { Ground }\end{array}$ & $\begin{array}{c}14.22 \pm \\
2.07\end{array}$ & $\begin{array}{c}11.74 \pm \\
4.32\end{array}$ & $* * * *$ & $\begin{array}{c}7.59 \pm \\
1.76\end{array}$ & $\begin{array}{c}12.56 \pm \\
1.63\end{array}$ & 11.28 & $\begin{array}{l}2.34 \\
(0.08\end{array}$ \\
\hline Stone & $\begin{array}{c}3.76 \pm \\
1.64\end{array}$ & $\begin{array}{c}1.94 \pm \\
3.42\end{array}$ & $* * * *$ & $\begin{array}{c}4.24 \pm \\
1.4\end{array}$ & $\begin{array}{c}4.51 \pm \\
1.29\end{array}$ & 4.1 & $\begin{array}{l}0.18 \\
(0.91\end{array}$ \\
\hline Stump & $0 \pm 0.01$ & $\begin{array}{c}<0.00 \pm \\
0.02\end{array}$ & $* * * *$ & $\begin{array}{c}<0.00 \pm \\
0.01\end{array}$ & $\begin{array}{c}0.01 \pm \\
0.01\end{array}$ & 0 & $\begin{array}{r}0.53 \\
(0.67 \\
\end{array}$ \\
\hline Tree Base & $\begin{array}{c}0.17 \pm \\
0.08\end{array}$ & $\begin{array}{l}0.1 \pm \\
0.17\end{array}$ & $* * * *$ & $\begin{array}{c}0.09 \pm \\
0.07\end{array}$ & $\begin{array}{c}0.06 \pm \\
0.07\end{array}$ & 0.1 & $\begin{array}{l}0.37 \\
10.78\end{array}$ \\
\hline Fine Litter & $\begin{array}{c}35.9 \pm \\
5.41 \\
\end{array}$ & $\begin{array}{l}46.7 \pm \\
11.25 \\
\end{array}$ & $* * * *$ & $\begin{array}{c}39.92 \pm \\
4.59 \\
\end{array}$ & $\begin{array}{c}42.54 \pm \\
4.25 \\
\end{array}$ & 40.34 & $\begin{array}{l}0.42 \\
(0.74 \\
\end{array}$ \\
\hline Moss & $\begin{array}{c}4.49 \pm \\
2.19 \\
\end{array}$ & $\begin{array}{l}8.9 \pm \\
4.56 \\
\end{array}$ & $* * * *$ & $\begin{array}{c}5.33 \pm \\
1.86 \\
\end{array}$ & $\begin{array}{c}6.56 \pm \\
1.72 \\
\end{array}$ & 5.8 & $\begin{array}{l}0.36 \\
(0.78 \\
\end{array}$ \\
\hline Lichen & $\begin{array}{c}0.01 \pm \\
0.05\end{array}$ & $\begin{array}{c}0.52 \pm \\
0.11 \\
\end{array}$ & $* * * *$ & $0 \pm 0.04$ & $\begin{array}{c}0.05 \pm \\
0.04 \\
\end{array}$ & 0.05 & $\begin{array}{c}6.76 \\
(0.0006 \\
\end{array}$ \\
\hline Lawn & $\begin{array}{c}22.79 \pm \\
4.58 \\
\end{array}$ & $\begin{array}{c}21.52 \pm \\
9.54 \\
\end{array}$ & $* * * *$ & $\begin{array}{c}21.21 \pm \\
3.9 \\
\end{array}$ & $\begin{array}{c}13.72 \pm \\
3.61 \\
\end{array}$ & 18.74 & $\begin{array}{l}1.07 \\
(0.37 \\
\end{array}$ \\
\hline Mulch & $\begin{array}{c}17.49 \pm \\
6.36\end{array}$ & $\begin{array}{c}15.37 \pm \\
13.25\end{array}$ & $* * * *$ & $\begin{array}{c}25.26 \pm \\
5.41\end{array}$ & $\begin{array}{c}15.32 \pm \\
5.01\end{array}$ & 19.09 & $\begin{array}{l}0.67 \\
(0.57\end{array}$ \\
\hline $\begin{array}{l}\text { Herbaceou } \\
\mathrm{s}\end{array}$ & $\begin{array}{c}32.32 \pm \\
4.48 \\
\end{array}$ & $\begin{array}{c}35.77 \pm \\
9.32 \\
\end{array}$ & $* * * *$ & $\begin{array}{c}36.46 \pm \\
3.8 \\
\end{array}$ & $\begin{array}{c}40.04 \pm \\
3.52 \\
\end{array}$ & 36.81 & $\begin{array}{l}0.62 \\
(0.60 \\
\end{array}$ \\
\hline Shrub & $\begin{array}{c}49.68 \pm \\
6.46 \\
\end{array}$ & $\begin{array}{c}57.23 \pm \\
13.45 \\
\end{array}$ & $* * * *$ & $\begin{array}{c}50.92 \pm \\
5.49 \\
\end{array}$ & $\begin{array}{c}44.34 \pm \\
5.08 \\
\end{array}$ & 48.46 & $\begin{array}{l}0.44 \\
(0.73 \\
\end{array}$ \\
\hline Tree & $\begin{array}{c}33.18 \pm \\
5.42 \\
\end{array}$ & $\begin{array}{c}34.53 \pm \\
11.28 \\
\end{array}$ & $* * * *$ & $\begin{array}{c}31.99 \pm \\
4.6 \\
\end{array}$ & $\begin{array}{c}39.25 \pm \\
4.26 \\
\end{array}$ & 35.18 & $\begin{array}{l}0.51 \\
0.68 \\
\end{array}$ \\
\hline Exotic Herb & $\begin{array}{c}19.01 \pm \\
3.75 \\
\end{array}$ & $\begin{array}{c}14.75 \pm \\
7.8 \\
\end{array}$ & $* * * *$ & $\begin{array}{c}20.28 \pm \\
3.19 \\
\end{array}$ & $\begin{array}{c}21.09 \pm \\
2.95 \\
\end{array}$ & 19.99 & $\begin{array}{l}0.22 \\
(0.88 \\
\end{array}$ \\
\hline $\begin{array}{l}\text { Exotic } \\
\text { Shrub }\end{array}$ & $\begin{array}{c}14.69 \pm \\
3.86 \\
\end{array}$ & $\begin{array}{c}18.3 \pm \\
8.03 \\
\end{array}$ & $* * * *$ & $\begin{array}{c}12.49 \pm \\
3.28 \\
\end{array}$ & $\begin{array}{c}11.15 \pm \\
3.04 \\
\end{array}$ & 12.81 & $\begin{array}{l}0.34 \\
(0.80 \\
\end{array}$ \\
\hline Exotic Tree & $\begin{array}{c}19.8 \pm \\
4.52 \\
\end{array}$ & $\begin{array}{c}10.23 \pm \\
9.41 \\
\end{array}$ & $* * * *$ & $\begin{array}{c}17.43 \pm \\
3.84 \\
\end{array}$ & $\begin{array}{c}13.39 \pm \\
3.56 \\
\end{array}$ & 16.05 & $\begin{array}{l}0.59 \\
(0.63 \\
\end{array}$ \\
\hline $\begin{array}{l}\text { Native } \\
\text { Herb }\end{array}$ & $\begin{array}{c}17.4 \pm \\
3.69 \\
\end{array}$ & $\begin{array}{c}19.57 \pm \\
7.69\end{array}$ & $* * * *$ & $\begin{array}{c}18.63 \pm \\
3.14 \\
\end{array}$ & $\begin{array}{c}20.89 \pm \\
2.91 \\
\end{array}$ & 19.25 & $\begin{array}{l}0.20 \\
(0.89 \\
\end{array}$ \\
\hline $\begin{array}{l}\text { Native } \\
\text { Shrub }\end{array}$ & $\begin{array}{c}38.23 \pm \\
4.84 \\
\end{array}$ & $\begin{array}{c}37.62 \pm \\
10.07 \\
\end{array}$ & $* * * *$ & $\begin{array}{c}39.29 \pm \\
4.11 \\
\end{array}$ & $\begin{array}{c}33.26 \pm \\
3.81 \\
\end{array}$ & 36.65 & $\begin{array}{l}0.44 \\
(0.73 \\
\end{array}$ \\
\hline \multirow[t]{2}{*}{ Native Tree } & $\begin{array}{c}12.83 \pm \\
4.96 \\
\end{array}$ & $\begin{array}{c}26.25 \pm \\
10.32 \\
\end{array}$ & $* * * *$ & $\begin{array}{c}16.48 \pm \\
4.21 \\
\end{array}$ & $\begin{array}{c}27.21 \pm \\
3.9 \\
\end{array}$ & 20.25 & $\begin{array}{l}2.19 \\
(0.10 \\
\end{array}$ \\
\hline & \multicolumn{7}{|c|}{ Platinum } \\
\hline $\begin{array}{l}\text { Bare } \\
\text { Ground }\end{array}$ & $\begin{array}{c}.59 \pm \\
9.01\end{array}$ & $* * * *$ & $\begin{array}{c}22.03 \pm \\
7.36\end{array}$ & $\begin{array}{c}8.05 \pm \\
9.01\end{array}$ & $\begin{array}{c}16.84 \pm \\
5.2\end{array}$ & 14.8 & $\begin{array}{c}0.99 \\
(0.44)\end{array}$ \\
\hline
\end{tabular}




\begin{tabular}{|c|c|c|c|c|c|c|c|}
\hline Stone & $\begin{array}{c}1.48 \pm \\
5.64\end{array}$ & $* * * *$ & $\begin{array}{c}7.77 \pm \\
4.6\end{array}$ & $\begin{array}{c}16.35 \pm \\
5.64\end{array}$ & $\begin{array}{c}1.26 \pm \\
3.26\end{array}$ & 5.12 & $\begin{array}{c}2.04 \\
(0.18)\end{array}$ \\
\hline Stump & $\begin{array}{c}<0.00 \pm \\
0.28\end{array}$ & $* * * *$ & $\begin{array}{c}<0.00 \pm \\
0.23\end{array}$ & $\begin{array}{c}<0.00 \pm \\
0.28\end{array}$ & $\begin{array}{c}0.33 \pm \\
0.16\end{array}$ & 0.15 & $\begin{array}{c}0.73 \\
(0.56) \\
\end{array}$ \\
\hline Tree Base & $0 \pm 0.15$ & $* * * *$ & $\begin{array}{c}0.06 \pm \\
0.13\end{array}$ & $\begin{array}{c}0.38 \pm \\
0.15\end{array}$ & $\begin{array}{c}0.06 \pm \\
0.09\end{array}$ & 0.1 & $\begin{array}{c}1.31 \\
(0.33)\end{array}$ \\
\hline Fine Litter & $\begin{array}{c}34.64 \pm \\
16.07 \\
\end{array}$ & $* * * *$ & $\begin{array}{c}26.26 \pm \\
13.12 \\
\end{array}$ & $\begin{array}{c}50.36 \pm \\
16.07 \\
\end{array}$ & $\begin{array}{c}48.28 \pm \\
9.28 \\
\end{array}$ & 41.42 & $\begin{array}{c}0.79 \\
(0.53) \\
\end{array}$ \\
\hline Moss & $\begin{array}{c}4.39 \pm \\
8.91\end{array}$ & $* * * *$ & $\begin{array}{c}23.07 \\
(0.05 \pm \\
7.28\end{array}$ & $\begin{array}{c}0.38 \pm \\
8.91\end{array}$ & $\begin{array}{c}5.18 \pm \\
5.15\end{array}$ & 8.44 & $\begin{array}{c}1.82 \\
(0.21)\end{array}$ \\
\hline Lichen & $\begin{array}{c}<0.00 \pm \\
0.31\end{array}$ & $* * * *$ & $\begin{array}{c}0.42 \pm \\
0.25\end{array}$ & $\begin{array}{c}<0.0 \pm \\
0.31\end{array}$ & $\begin{array}{c}0.33 \pm \\
0.18\end{array}$ & 0.25 & $\begin{array}{c}0.68 \\
(0.58)\end{array}$ \\
\hline Lawn & $\begin{array}{c}17.73 \pm \\
3.15 \\
(0.002) \\
\end{array}$ & $* * * *$ & $\begin{array}{c}3.03 \pm \\
2.57 \\
\end{array}$ & $\begin{array}{c}<0.00 \pm \\
3.15 \\
(0.05) \\
\end{array}$ & $\begin{array}{c}2.99 \pm \\
1.82 \\
\end{array}$ & 4.81 & $\begin{array}{r}6.87 \\
(0.01) \\
\end{array}$ \\
\hline Mulch & $\begin{array}{c}38.22 \pm \\
19.37\end{array}$ & $* * * *$ & $\begin{array}{l}1.67 \pm \\
15.82\end{array}$ & $\begin{array}{l}7.5 \pm \\
19.37\end{array}$ & $\begin{array}{c}21.47 \pm \\
11.18\end{array}$ & 17.33 & $\begin{array}{c}0.85 \\
(0.50)\end{array}$ \\
\hline $\begin{array}{l}\text { Herbaceou } \\
\mathrm{s}\end{array}$ & $\begin{array}{c}39.44 \pm \\
18.78\end{array}$ & $* * * *$ & $\begin{array}{l}48.4 \pm \\
15.34\end{array}$ & $\begin{array}{c}66.76 \pm \\
18.78\end{array}$ & $\begin{array}{c}30.68 \pm \\
10.84\end{array}$ & 41.67 & $\begin{array}{c}1.01 \\
(0.43)\end{array}$ \\
\hline Shrub & $\begin{array}{c}57.63 \pm \\
15.35 \\
\end{array}$ & $* * * *$ & $\begin{array}{c}55.46 \pm \\
12.53 \\
\end{array}$ & $\begin{array}{c}19.31 \pm \\
15.35 \\
\end{array}$ & $\begin{array}{c}50.77 \pm \\
8.86\end{array}$ & 48.07 & $\begin{array}{c}1.45 \\
(0.29) \\
\end{array}$ \\
\hline Tree & $\begin{array}{c}24.03 \pm \\
17.56\end{array}$ & $* * * *$ & $\begin{array}{c}52.23 \pm \\
14.34\end{array}$ & $\begin{array}{c}44.47 \pm \\
17.56\end{array}$ & $\begin{array}{c}55.07 \pm \\
10.14\end{array}$ & 48.01 & $\begin{array}{c}0.83 \\
(0.51)\end{array}$ \\
\hline Exotic Herb & $\begin{array}{c}28.2 \pm \\
16.1\end{array}$ & $* * * *$ & $\begin{array}{c}10.06 \pm \\
13.14\end{array}$ & $\begin{array}{c}31.35 \pm \\
16.1\end{array}$ & $\begin{array}{c}18.54 \pm \\
9.29\end{array}$ & 20.04 & $\begin{array}{c}0.45 \\
(0.72)\end{array}$ \\
\hline $\begin{array}{l}\text { Exotic } \\
\text { Shrub }\end{array}$ & $\begin{array}{c}5.83 \pm \\
7.2 \\
\end{array}$ & $* * * *$ & $\begin{array}{c}10.83 \pm \\
5.88 \\
\end{array}$ & $\begin{array}{c}5.83 \pm \\
7.2 \\
\end{array}$ & $\begin{array}{c}17.32 \pm \\
4.16 \\
\end{array}$ & 12.29 & $\begin{array}{c}1.04 \\
(0.42) \\
\end{array}$ \\
\hline Exotic Tree & $\begin{array}{c}19.68 \pm \\
11.37\end{array}$ & $* * * *$ & $\begin{array}{c}6.37 \pm \\
9.28\end{array}$ & $\begin{array}{l}7.81 \pm \\
11.37\end{array}$ & $\begin{array}{c}15.38 \pm \\
6.57\end{array}$ & 12.8 & $\begin{array}{c}0.40 \\
(0.76)\end{array}$ \\
\hline $\begin{array}{l}\text { Native } \\
\text { Herb }\end{array}$ & $\begin{array}{c}11.57 \pm \\
13.48\end{array}$ & $* * * *$ & $\begin{array}{c}41.17 \pm \\
11.01\end{array}$ & $\begin{array}{c}44.53 \pm \\
13.48\end{array}$ & $\begin{array}{c}14.02 \pm \\
7.78\end{array}$ & 24.6 & $\begin{array}{c}2.41 \\
(0.13)\end{array}$ \\
\hline $\begin{array}{l}\text { Native } \\
\text { Shrub }\end{array}$ & $\begin{array}{c}52.84 \pm \\
16.73\end{array}$ & $* * * *$ & $\begin{array}{c}41.81 \pm \\
13.66 \\
\end{array}$ & $\begin{array}{c}14.08 \pm \\
16.73 \\
\end{array}$ & $\begin{array}{c}32.98 \pm \\
9.66\end{array}$ & 35.17 & $\begin{array}{c}1.00 \\
(0.44) \\
\end{array}$ \\
\hline Native Tree & $4.36 \pm 16$ & $* * * *$ & $\begin{array}{c}43.28 \pm \\
13.07 \\
\end{array}$ & $\begin{array}{c}37.28 \pm \\
16 \\
\end{array}$ & $\begin{array}{c}45.24 \pm \\
9.24 \\
\end{array}$ & 37.28 & $\begin{array}{c}1.73 \\
(0.23) \\
\end{array}$ \\
\hline & \multicolumn{7}{|c|}{ All Sites } \\
\hline $\begin{array}{l}\text { Bare } \\
\text { Ground }\end{array}$ & $\begin{array}{c}9.67 \pm \\
1.48\end{array}$ & $\begin{array}{c}14.27 \pm \\
3.09 \\
\end{array}$ & $\begin{array}{c}15.52 \pm \\
3.91 \\
\end{array}$ & $\begin{array}{c}9.22 \pm \\
1.27 \\
(0.047) \\
\end{array}$ & $\begin{array}{c}12.2 \pm \\
1.21 \\
\end{array}$ & 10.87 & $\begin{array}{c}1.54 \\
(0.19) \\
\end{array}$ \\
\hline Stone & $\begin{array}{c}5.31 \pm \\
1.11\end{array}$ & $\begin{array}{c}1.61 \pm \\
2.31\end{array}$ & $\begin{array}{c}9.76 \pm \\
2.93\end{array}$ & $\begin{array}{c}4.81 \pm \\
0.96\end{array}$ & $\begin{array}{l}3.7 \pm \\
0.91\end{array}$ & 4.53 & $\begin{array}{c}1.55 \\
(0.19)\end{array}$ \\
\hline Stump & $\begin{array}{c}0.05 \pm \\
0.04\end{array}$ & $\begin{array}{c}0.06 \pm \\
0.08\end{array}$ & $0 \pm 0.1$ & $0 \pm 0.03$ & $\begin{array}{c}0.09 \pm \\
0.03\end{array}$ & 0.05 & $\begin{array}{c}1.62 \\
(0.33)\end{array}$ \\
\hline Tree Base & $\begin{array}{c}0.13 \pm \\
0.05\end{array}$ & $\begin{array}{c}0.18 \pm \\
0.11\end{array}$ & $\begin{array}{c}0.03 \pm \\
0.14\end{array}$ & $\begin{array}{c}0.12 \pm \\
0.04\end{array}$ & $\begin{array}{c}0.11 \pm \\
0.04\end{array}$ & 0.12 & $\begin{array}{c}0.20 \\
(0.94)\end{array}$ \\
\hline
\end{tabular}




\begin{tabular}{|c|c|c|c|c|c|c|c|}
\hline Fine Litter & $\begin{array}{c}29.55 \pm \\
3.16 \\
\end{array}$ & $\begin{array}{c}36.65 \pm \\
6.62\end{array}$ & $\begin{array}{c}29.44 \pm \\
8.37 \\
\end{array}$ & $\begin{array}{c}38.52 \pm \\
2.73\end{array}$ & $\begin{array}{c}44.65 \pm \\
2.59 \\
(0.005)\end{array}$ & 38.14 & $\begin{array}{c}3.7 \\
(0.007)\end{array}$ \\
\hline Moss & $\begin{array}{c}3.67 \pm \\
1.47 \\
(0.001)\end{array}$ & $\begin{array}{c}10.54 \pm \\
3.08\end{array}$ & $\begin{array}{c}17.08 \pm \\
3.9 \\
(0.13)\end{array}$ & $\begin{array}{c}4.74 \pm \\
1.27 \\
(0.005)\end{array}$ & $\begin{array}{c}8.95 \pm \\
1.21\end{array}$ & 6.71 & $\begin{array}{c}4.67 \\
(0.001)\end{array}$ \\
\hline Lichen & $\begin{array}{c}0.13 \pm \\
0.08\end{array}$ & $\begin{array}{l}0.3 \pm \\
0.16\end{array}$ & $\begin{array}{c}0.25 \pm \\
0.21\end{array}$ & $\begin{array}{l}0.1 \pm \\
0.07\end{array}$ & $\begin{array}{c}0.07 \pm \\
0.06\end{array}$ & 0.12 & $\begin{array}{c}0.56 \\
(0.69)\end{array}$ \\
\hline Lawn & $\begin{array}{c}25.12 \pm \\
3.15 \\
\end{array}$ & $\begin{array}{c}30.91 \pm \\
6.6\end{array}$ & $\begin{array}{c}8.86 \pm \\
8.34 \\
\end{array}$ & $\begin{array}{c}22.29 \pm \\
2.72 \\
\end{array}$ & $\begin{array}{c}16.06 \pm \\
2.59 \\
\end{array}$ & 20.77 & $\begin{array}{c}2.49 \\
(0.046) \\
\end{array}$ \\
\hline Mulch & $\begin{array}{c}26.41 \pm \\
3.79\end{array}$ & $\begin{array}{c}12.26 \pm \\
7.94\end{array}$ & $\begin{array}{c}10 \pm \\
10.04\end{array}$ & $\begin{array}{c}22.2 \pm \\
3.27\end{array}$ & $\begin{array}{c}18.07 \pm \\
3.11\end{array}$ & 20.79 & $\begin{array}{c}1.36 \\
(0.25)\end{array}$ \\
\hline $\begin{array}{l}\text { Herbaceou } \\
\text { s }\end{array}$ & $\begin{array}{c}34.89 \pm \\
2.98\end{array}$ & $\begin{array}{c}35.62 \pm \\
6.24\end{array}$ & $\begin{array}{c}42.54 \pm \\
7.89 \\
\end{array}$ & $\begin{array}{c}37.77 \pm \\
2.57\end{array}$ & $\begin{array}{c}37.73 \pm \\
2.45\end{array}$ & 37.12 & $\begin{array}{c}0.30 \\
(0.87) \\
\end{array}$ \\
\hline Shrub & $\begin{array}{c}39.11 \pm \\
3.9\end{array}$ & $\begin{array}{c}34.69 \pm \\
8.16\end{array}$ & $\begin{array}{c}57.17 \pm \\
10.32 \\
\end{array}$ & $\begin{array}{c}42.29 \pm \\
3.37\end{array}$ & $\begin{array}{c}41.31 \pm \\
3.2\end{array}$ & 41.28 & $\begin{array}{c}0.86 \\
(0.49) \\
\end{array}$ \\
\hline Tree & $\begin{array}{c}28.04 \pm \\
3.12\end{array}$ & $\begin{array}{c}37.97 \pm \\
6.52\end{array}$ & $\begin{array}{c}51.99 \pm \\
8.25\end{array}$ & $\begin{array}{c}30.41 \pm \\
2.69\end{array}$ & $\begin{array}{c}40.5 \pm \\
2.56\end{array}$ & 34.56 & $\begin{array}{c}4.22 \\
(0.003)\end{array}$ \\
\hline Exotic Herb & $\begin{array}{c}21.57 \pm \\
2.51\end{array}$ & $\begin{array}{c}23.71 \pm \\
5.26 \\
\end{array}$ & $\begin{array}{c}15.82 \pm \\
6.65 \\
\end{array}$ & $\begin{array}{c}21.03 \pm \\
2.17\end{array}$ & $\begin{array}{c}23.41 \pm \\
2.06\end{array}$ & 21.97 & $\begin{array}{c}0.42 \\
(0.80) \\
\end{array}$ \\
\hline $\begin{array}{l}\text { Exotic } \\
\text { Shrub }\end{array}$ & $\begin{array}{c}13.34 \pm \\
2.47\end{array}$ & $\begin{array}{c}9.49 \pm \\
5.16 \\
\end{array}$ & $\begin{array}{c}13.8 \pm \\
6.53 \\
\end{array}$ & $\begin{array}{c}15.37 \pm \\
2.13\end{array}$ & $\begin{array}{c}14.76 \pm \\
2.03\end{array}$ & 14.3 & $\begin{array}{c}0.33 \\
(0.86) \\
\end{array}$ \\
\hline Exotic Tree & $\begin{array}{c}18.3 \pm \\
2.46 \\
\end{array}$ & $\begin{array}{c}13.06 \pm \\
5.15 \\
\end{array}$ & $\begin{array}{c}3.82 \pm \\
6.52 \\
\end{array}$ & $\begin{array}{c}15.99 \pm \\
2.13\end{array}$ & $\begin{array}{c}15.09 \pm \\
2.02\end{array}$ & 15.65 & $\begin{array}{c}1.20 \\
(0.31) \\
\end{array}$ \\
\hline $\begin{array}{l}\text { Native } \\
\text { Herb }\end{array}$ & $\begin{array}{c}15.49 \pm \\
2.35\end{array}$ & $\begin{array}{c}11.33 \pm \\
4.91\end{array}$ & $\begin{array}{c}27.6 \pm \\
6.21 \\
\end{array}$ & $\begin{array}{c}18.8 \pm \\
2.03 \\
\end{array}$ & $\begin{array}{c}16.22 \pm \\
1.93\end{array}$ & 16.99 & $\begin{array}{c}1.40 \\
(0.24) \\
\end{array}$ \\
\hline $\begin{array}{l}\text { Native } \\
\text { Shrub }\end{array}$ & $\begin{array}{c}26.98 \pm \\
3.27\end{array}$ & $\begin{array}{c}25.45 \pm \\
6.84\end{array}$ & $\begin{array}{c}41.37 \pm \\
8.66 \\
\end{array}$ & $\begin{array}{c}27.97 \pm \\
2.82 \\
\end{array}$ & $\begin{array}{c}26.77 \pm \\
2.68\end{array}$ & 27.63 & $\begin{array}{c}0.70 \\
(0.60) \\
\end{array}$ \\
\hline Native Tree & $\begin{array}{c}9.71 \pm \\
2.84 \\
(0.001)\end{array}$ & $\begin{array}{c}25.72 \pm \\
5.94\end{array}$ & $\begin{array}{c}46.62 \pm \\
7.52 \\
(0.006)\end{array}$ & $\begin{array}{c}15.11 \pm \\
2.45 \\
(0.007)\end{array}$ & $\begin{array}{c}27.75 \pm \\
2.33\end{array}$ & 19.94 & $\begin{array}{c}10.40 \\
(<0.001)\end{array}$ \\
\hline
\end{tabular}




\begin{tabular}{|c|c|}
\hline \multicolumn{2}{|c|}{$\begin{array}{l}\text { Appendix B Table 3: National Wildlife Federation certification criteria as taken from } \\
\text { the NWF website in } 2016 .\end{array}$} \\
\hline 3 food sources; Examples: & Sustainability; Do 2 of the following: \\
\hline \multicolumn{2}{|l|}{$\begin{array}{l}\text { Native plants that offer seeds, berries, } \\
\text { nuts or nectar }\end{array}$} \\
\hline Healthy insect population & Soil and water conservation; Examples \\
\hline \multirow[t]{2}{*}{ Supplemental bird feeders } & Limit water use \\
\hline & Compost \\
\hline 1 water source; Examples: & Mulch \\
\hline Birdbath & Reduce lawn and pavement \\
\hline Water garden & Use soaker hose \\
\hline Water dish & Install rain garden \\
\hline \multicolumn{2}{|l|}{ Natural steam or pond } \\
\hline & $\begin{array}{l}\text { Controlling invasive exotic species; } \\
\text { Examples: }\end{array}$ \\
\hline 2 sources of cover; Examples: & Use native plants \\
\hline Dense vegetation & Remove invasive exotic plants \\
\hline Brush or rock pile & Keep cats indoors \\
\hline \multicolumn{2}{|l|}{ Bat house } \\
\hline \multirow[t]{2}{*}{ Roosting box } & Organic practices; Examples \\
\hline & $\begin{array}{l}\text { Eliminate chemical pesticides and } \\
\text { fertilizers }\end{array}$ \\
\hline 2 places to raise young; Examples: & Attract beneficial insects \\
\hline \multicolumn{2}{|l|}{ Trees and shrubs } \\
\hline \multicolumn{2}{|l|}{ Caterpillar host plants } \\
\hline \multicolumn{2}{|l|}{ Pond for amphibians } \\
\hline Bird nesting boxes & \\
\hline
\end{tabular}




\section{Appendix C}

\section{Chapter 3 Appendix Tables and Figures}

Appendix C Table 1: BHCP Program requirements. These are criteria were copied

from the Audubon Society or Portland website in 2016, and are publically available.

\begin{tabular}{|c|c|c|}
\hline \multicolumn{3}{|c|}{ Invasive Weeds (Prohibited) } \\
\hline Silver & Gold & Platinum \\
\hline $\begin{array}{l}\text { Evergreen and Armenian } \\
\text { Blackberry (Rubus laciniatus and } \\
\text { Rubus armeniacus) }\end{array}$ & $\begin{array}{l}\text { Butterfly Bush (Buddleia davidii } \\
\text { - all varieties) }\end{array}$ & $\begin{array}{l}\text { Creeping Jenny (Lysimachia } \\
\text { nummularia) }\end{array}$ \\
\hline $\begin{array}{l}\text { Garlic Mustard (Alliaria } \\
\text { petiolata) }\end{array}$ & $\begin{array}{l}\text { False Brome (Brachypodium } \\
\text { sylvaticum) }\end{array}$ & $\begin{array}{l}\text { English and Portuguese Laurel } \\
\text { (Prunus spp.) }\end{array}$ \\
\hline $\begin{array}{l}\text { Giant Hogweed (Heracleum } \\
\text { mantegazzianum) }\end{array}$ & $\begin{array}{l}\text { Hedge Bindweed (Calystegia } \\
\text { sepium) }\end{array}$ & Fennel (Foeniculum spp.) \\
\hline Ivy (all cultivars, Hedra spp.) & Italian Arum (Arum italicum) & $\begin{array}{l}\text { Large and Small-leaf } \\
\text { Periwinkle (Vinca spp.) }\end{array}$ \\
\hline Knotweed (Polygonum spp.) & $\begin{array}{l}\text { Japanese Butterbur (Petasites } \\
\text { japonica) }\end{array}$ & $\begin{array}{l}\text { Reed Canarygrass and Ribbon } \\
\text { Grass (Phalaris arundinacea) }\end{array}$ \\
\hline $\begin{array}{l}\text { Orange Hawkweed (Hieracium } \\
\text { aurantiacum) }\end{array}$ & $\begin{array}{l}\text { Lesser Celandine (Ranunculus } \\
\text { ficaria) }\end{array}$ & \\
\hline $\begin{array}{l}\text { Pokeweed (Phytolacca } \\
\text { americana) }\end{array}$ & $\begin{array}{l}\text { Pampas and Jubata Grass } \\
\text { (Cortaderia ssp.) }\end{array}$ & \\
\hline $\begin{array}{l}\text { Policeman's Helmet (Impatiens } \\
\text { glandulifera) }\end{array}$ & $\begin{array}{l}\text { Robert Geranium (Geranium } \\
\text { robertianum) }\end{array}$ & \\
\hline $\begin{array}{l}\text { Purple Loosestrife (Lythrum } \\
\text { salicaria) }\end{array}$ & $\begin{array}{l}\text { Shining Geranium (Geranium } \\
\text { lucidum) }\end{array}$ & \\
\hline \multicolumn{3}{|l|}{ Scot's Broom (Cytisus scoparius) } \\
\hline $\begin{array}{l}\text { Spotted, Meadow and Diffuse } \\
\text { Knapweeds (Centaurea spp.) }\end{array}$ & $\begin{array}{c}\text { Invasive Trees - } \\
\text { under 20ft }\end{array}$ & $\begin{array}{l}\text { Invasive Trees - } \\
\text { over } 20 \mathrm{ft}\end{array}$ \\
\hline Spurge Laurel (Daphne laureola) & $\begin{array}{l}\text { Black Locust (Robinia } \\
\text { pseudoacacia) }\end{array}$ & $\begin{array}{l}\text { Black Locust (Robinia } \\
\text { pseudoacacia) }\end{array}$ \\
\hline Traveler's Joy (Clematis vitalba) & $\begin{array}{l}\text { English Hawthorn (Crataegus } \\
\text { monogyna) }\end{array}$ & $\begin{array}{l}\text { English Hawthorn (Crataegus } \\
\text { monogyna) }\end{array}$ \\
\hline $\begin{array}{l}\text { Yellow Archangel (Lamiastrum } \\
\text { galeoblodon) }\end{array}$ & English Holly (Ilex aquifolium) & English Holly (Ilex aquifolium) \\
\hline $\begin{array}{l}\text { Yellow Flag Iris (Iris } \\
\text { pseudacorus) }\end{array}$ & $\begin{array}{l}\text { Norway Maple (Acer } \\
\text { platanoides) }\end{array}$ & $\begin{array}{l}\text { Norway Maple (Acer } \\
\text { platanoides) }\end{array}$ \\
\hline & $\begin{array}{l}\text { Tree-of-Heaven (Ailanthus } \\
\text { altissima) }\end{array}$ & $\begin{array}{l}\text { Tree-of-Heaven (Ailanthus } \\
\text { altissima) }\end{array}$ \\
\hline \multicolumn{3}{|c|}{ Vegetation and Pesticides } \\
\hline \multicolumn{2}{|l|}{ Vegetation } & Pesticides \\
\hline Silver & Silver & \\
\hline
\end{tabular}




\begin{tabular}{|c|c|}
\hline $\begin{array}{l}\text { Naturescape at least } 5 \% \text { of available property with } \\
\text { locally native plants* }\end{array}$ & $\begin{array}{l}\text { Use only YELLOW or GREEN zone chemicals if } \\
\text { necessary, according to an IPM strategy }\end{array}$ \\
\hline Include at least 3 out of 5 vegetation levels & No use of RED zone chemicals \\
\hline Gold & Gold \\
\hline $\begin{array}{l}\text { Naturescape at least } 15 \% \text { of available property } \\
\text { with locally native plants* }\end{array}$ & $\begin{array}{l}\text { Use only GREEN zone chemicals if necessary, } \\
\text { according to an IPM strategy }\end{array}$ \\
\hline Include at least 4 out of 5 vegetation levels & No use of RED or YELLOW zone chemicals \\
\hline Platinum & Platinum \\
\hline $\begin{array}{l}\text { Naturescape at least } 50 \% \text { of available property } \\
\text { with locally native plants* }\end{array}$ & $\begin{array}{l}\text { Use only GREEN zone chemicals if necessary, } \\
\text { according to an IPM strategy }\end{array}$ \\
\hline \multirow[t]{2}{*}{ Include all 5 vegetation levels } & No use of RED or YELLOW zone chemicals \\
\hline & Take the Metro No Pesticides Pledge \\
\hline \multicolumn{2}{|l|}{ Vegetation Levels } \\
\hline A. Overstory Canopy & Storm Water Management \\
\hline \multirow[t]{2}{*}{$\begin{array}{l}30 \text { feet or higher I Examples: Oregon White Oak } \\
\text { or Western Red Cedar }\end{array}$} & Gold 1, Sliver 2, Platinum 3 of the following: \\
\hline & $\begin{array}{l}\text { Large canopy tree over } 30 \mathrm{ft} \text { (cannot be nuisance } \\
\text { species) }\end{array}$ \\
\hline B. Understory Canopy & Disconnected downspouts where appropriate \\
\hline \multirow[t]{2}{*}{$\begin{array}{l}\text { Less than } 30 \text { feet | Examples: Vine Maple or } \\
\text { Cascara }\end{array}$} & Raingardens, where appropriate \\
\hline & $\begin{array}{l}\text { Remove impervious surfaces and/or grass } 500 \mathrm{ft} \\
\text { or more }\end{array}$ \\
\hline C. Large Shrub Layer & Ecoroof according to City specifications \\
\hline \multirow[t]{2}{*}{$\begin{array}{l}5 \text { to } 20 \text { feet | Examples: Indian Plum or } \\
\text { Serviceberry }\end{array}$} & $\begin{array}{l}\text { Increase naturescaping } 10 \% \text { higher than your } \\
\text { certification level requirement }\end{array}$ \\
\hline & Restore soils (i.e. leave the leaves) \\
\hline D. Small/Medium Shrub Layer & $\begin{array}{l}\text { Water conservation (i.e. eliminating lawn } \\
\text { irrigation, water in morning and evening only) }\end{array}$ \\
\hline Less than 5 feet | Examples: Salal or native ferns & $\begin{array}{l}\text { Adopt eco-friendly maintenance practicies (i.e. } \\
\text { petroleum-free yard care, use landscapers from } \\
\text { Backyard Landscape Directory) }\end{array}$ \\
\hline \multicolumn{2}{|l|}{ E. Ground Layer } \\
\hline \multicolumn{2}{|l|}{$\begin{array}{l}\text { Examples: Inside-out flower or Western Red } \\
\text { Columbine }\end{array}$} \\
\hline \multicolumn{2}{|c|}{ Wildlife Stewardship; Education and Volunteerism } \\
\hline Wildlife Stewardship & Education and Volunteerism \\
\hline Silver 1, Gold 2, Platinum 3 of the following: & Gold and Silver: Optional, Platinum At least 1 \\
\hline $\begin{array}{l}\text { Wildlife water feature (natural source, maintained } \\
\text { bird or bug bath) }\end{array}$ & Recruit 2 neighbors to signup. \\
\hline $\begin{array}{l}\text { Cats indoors at all times or in an outdoor } \\
\text { enclosure }\end{array}$ & Allow site to be showcased in a yard tour \\
\hline
\end{tabular}


Bird or bat nest boxes (appropriate to native species)

Pollinator and beneficial insect nesting habitat (i.e. rock piles, bundles of stems and branches, mason bee house)

Snag or nurse log

Reduce outdoor lighting during bird migration

(March-May, Sept-Nov)

Reduce bird window collisions

Native pollinator meadow which bloom through

the growing season
Volunteer for the Backyard Habitat Certification Program

Attend continuing education classes (i.e. EDRR Weed Watcher)

Participate in OSU Extension Master Gardener Programs 